\author{
SZEGEDI TUDOMÁNYEGYETEM \\ BÖLCSÉSZETTUDOMÁNYI KAR \\ NEVELÉSTUDOMÁNYI DOKTORI ISKOLA
}

\title{
SIMON TÜNDE
}

\section{A VIZUÁLIS KOMMUNIKÁCIÓS KÉPESSÉG DIAGNOSZTIKUS MÉRÉSE 4-6. ÉVFOLYAMBAN}

$\mathrm{PhD}$ értekezés

Témavezető:

Kárpáti Andrea, D.Sc.

egyetemi tanár

ELTE TTK, Természettudományi Kommunikáció

és UNESCO Multimédiapedagógia Központ

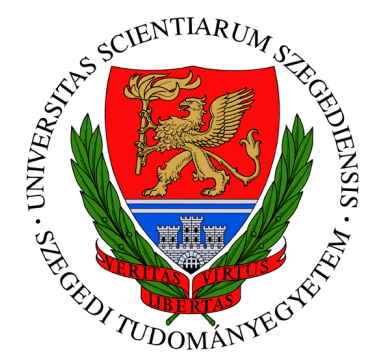

Szeged, 2018 
Tartalom

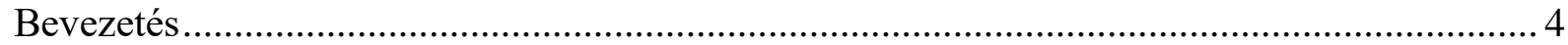

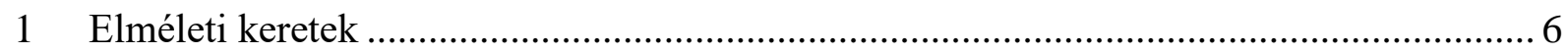

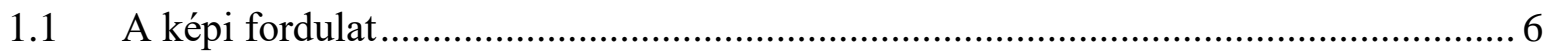

1.2 A vizuális kommunikáció helye a diszciplínák között ........................................... 10

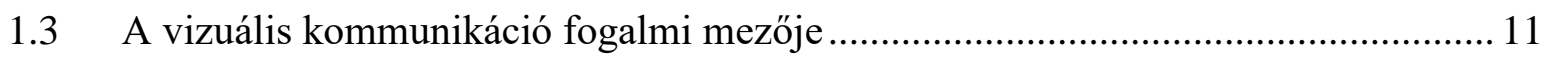

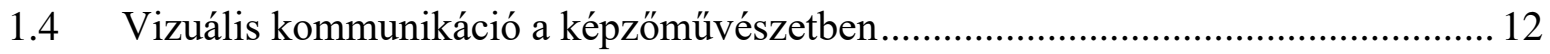

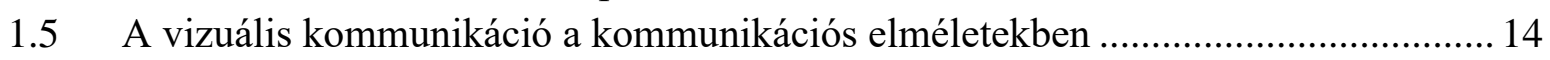

1.6 A vizuális nyelvi tartalmak, vizuális kódok és struktúrájuk .................................. 18

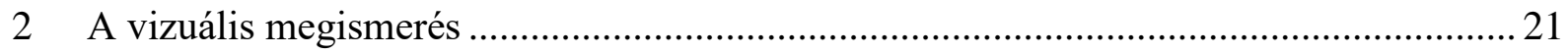

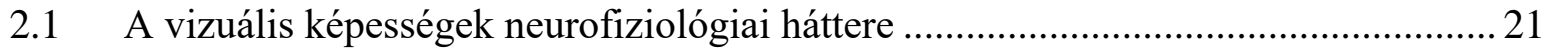

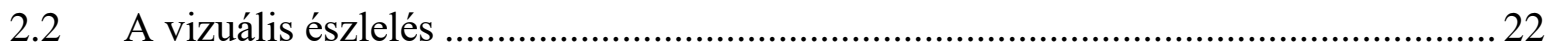

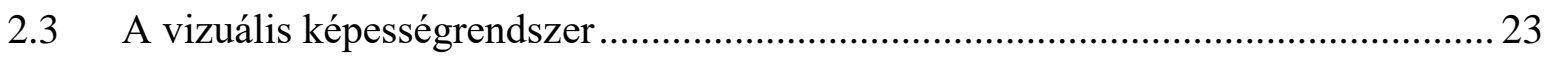

2.3.1 A vizuális képességrendszer fejlődési modelljei ........................................... 23

2.3.2 A vizuális kommunikációs képesség helye a vizuális képességek rendszerében 26

2.4 A 10-12 éves gyermekek képi közlésének sajátosságai ....................................... 30

3 A vizuális kommunikáció helye és szerepe a pedagógiai gyakorlatban .......................... 32

3.1 A vizuális kommunikáció a vizuális nevelés történetében ........................................ 32

3.2 A vizuális kommunikáció helye a rajz- és vizuális kultúra tantárgy kereteiben:

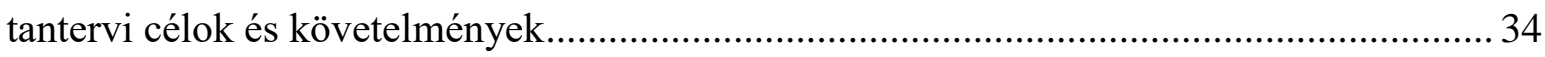

3.3 A vizuális képességek értékelési lehetőségei a hazai és a nemzetközi pedagógiai

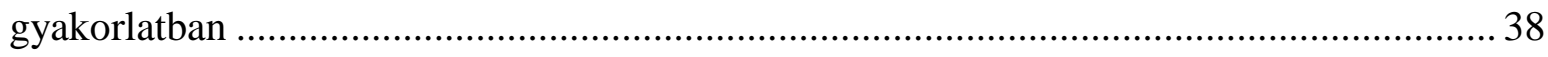

4 A digitalizáció beépülése a vizuális kultúrába és kommunikációba, a technológiai alapú

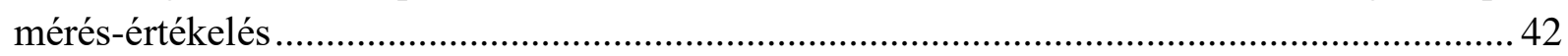

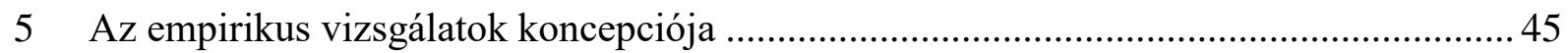

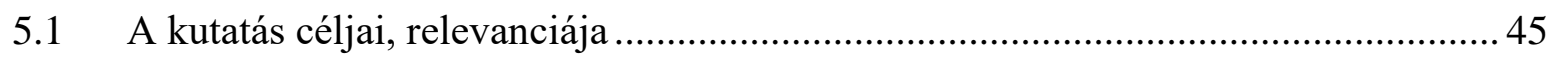

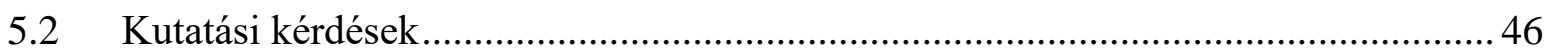

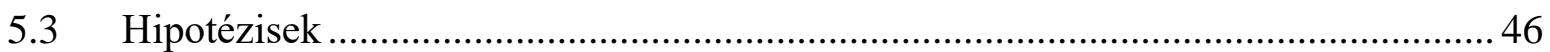

6 A vizuális kommunikációs képességek mérésére szolgáló eszközök kidolgozása, a

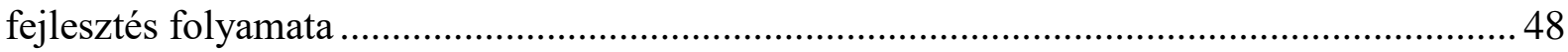

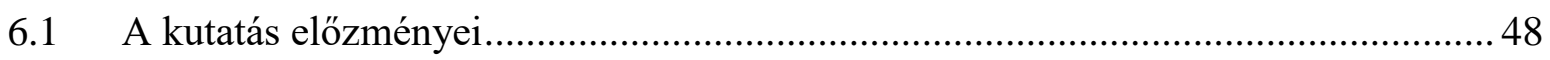

6.2 A pilot mérés keretei, a mérőeszköz fejlesztése .................................................. 50

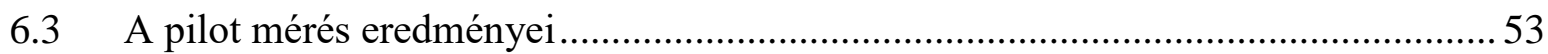

7 A vizuális kommunikációs képességek online diagnosztikus mérése a 4-6. évfolyamon 56

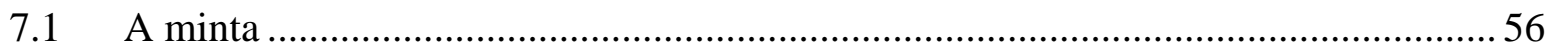

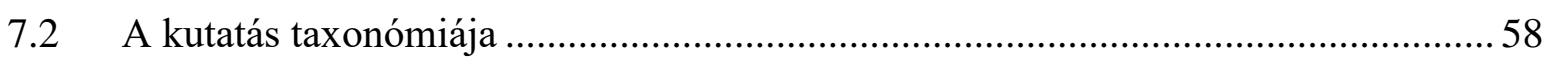

7.3 A kutatásban alkalmazott mérőeszközök bemutatása, a háttérváltozók leírása ........ 62

7.3.1 A vizuális kommunikációs képességeket mérő tesztek feladatai .........................62 62

7.3.2 A mérőeszköz feladatainak bemutatása részképességenként.............................64

7.3.3 A mérőeszköz feladatainak bemutatása képességszintenként.............................67

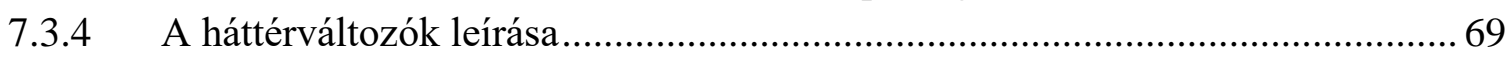

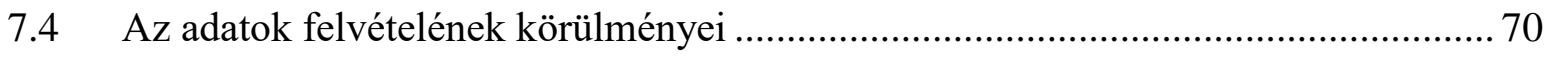

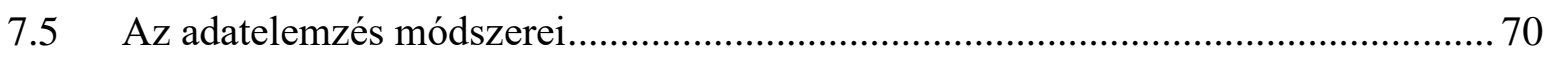


7.6 A teszt müködésére vonatkozó eredmények

7.6.1 A vizuális kommunikációs képesség teszt pszichometriai jellemzői 4.

évfolyamban.

7.6.2 A vizuális kommunikációs képesség teszt pszichometriai jellemzői 5.

évfolyamban.

7.6.3 A vizuális kommunikációs képesség teszt pszichometriai jellemzői 6. évfolyamban

7.6.4 A vizuális kommunikációs képességet mérő tesztek pszichometriai jellemzőinek összegzése .86

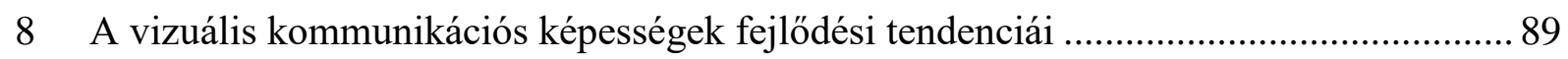

8.1 Évfolyamok közötti különbségek, fejlödési tendenciák .......................................... 89

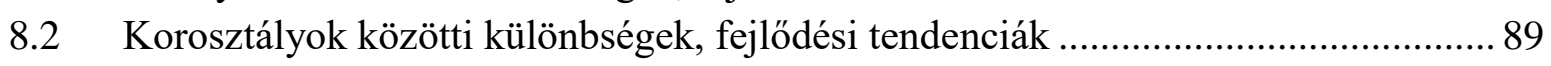

8.3 A mindhárom évfolyamon megoldott horgonyitemek vizsgálata ........................... 90

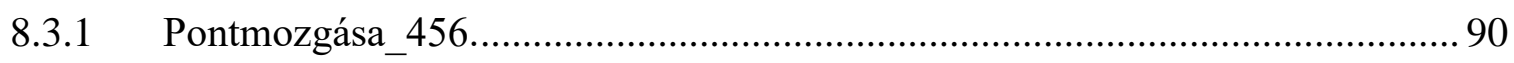

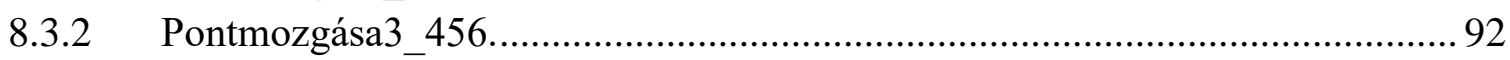

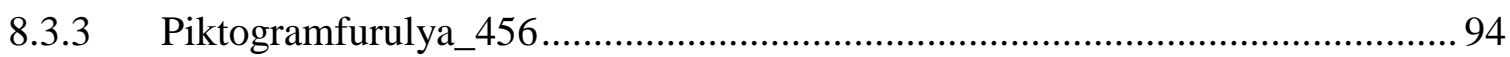

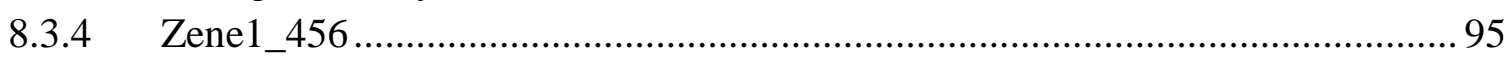

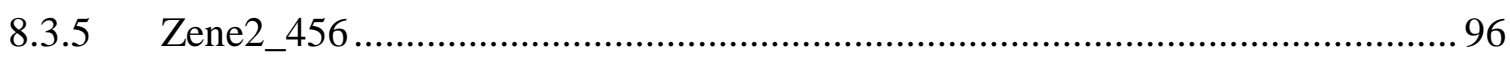

8.3.6 A horgony itemekböl álló teszt vizsgálata ................................................ 99

9 A vizuális kommunikáció teszten elért teljesítmény összefüggései a háttérváltozókkal 101

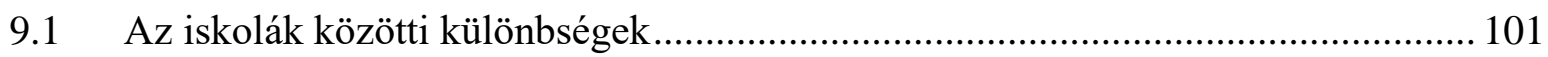

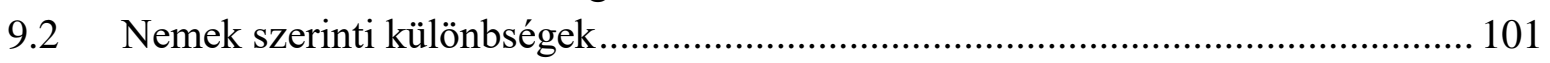

9.3 A vizuális kommunikáció teszten elért teljesítmény az osztályzatok és az attitüdök

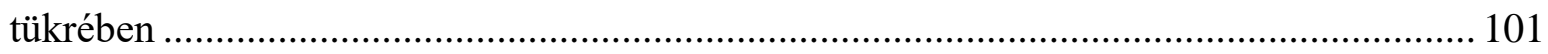

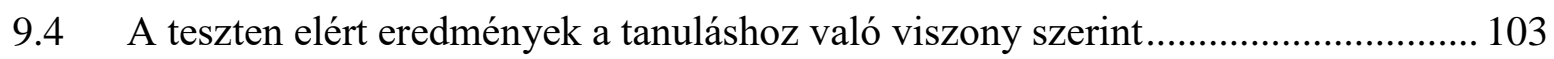

9.5 A családi háttér szerinti különbségek ............................................................. 103

9.5.1 A szülők legmagasabb iskolai végzettségének kapcsolata a teszten elért

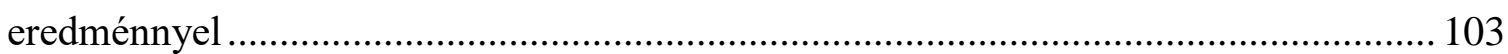

9.5.2 A teszten elért eredmény kapcsolata egyéb szociális háttérváltozókkal ........... 105

9.6 A számítógép-használat és a teszten elért eredmények kapcsolata ........................ 105

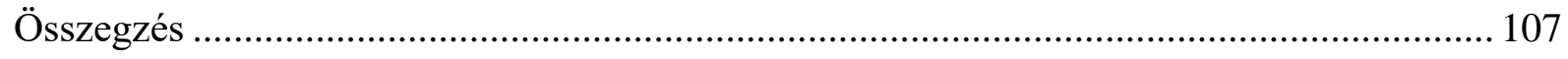

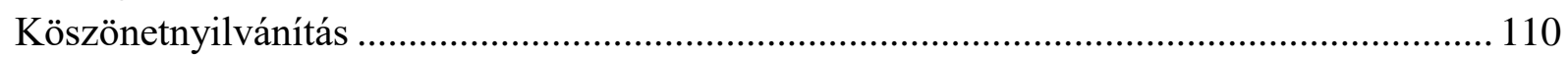

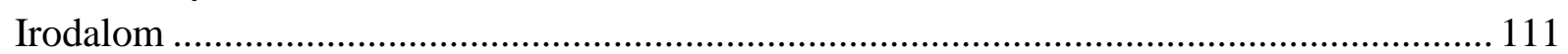

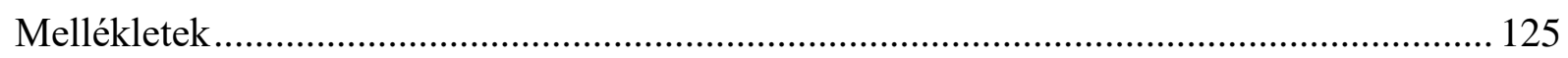

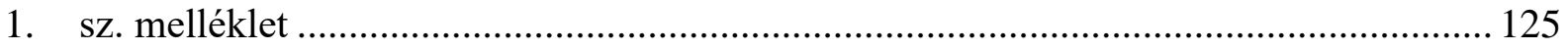

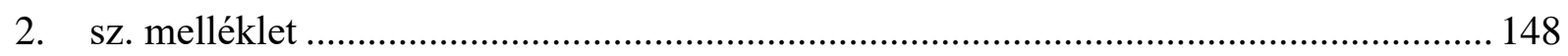

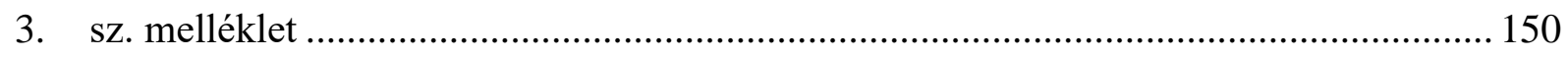

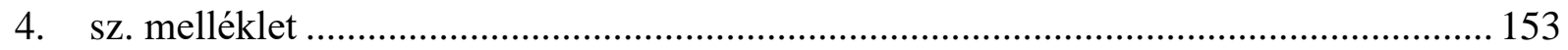

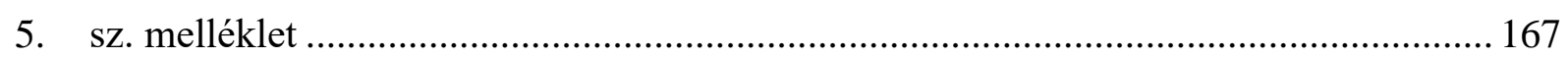

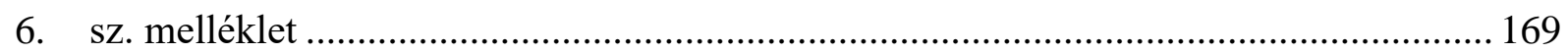

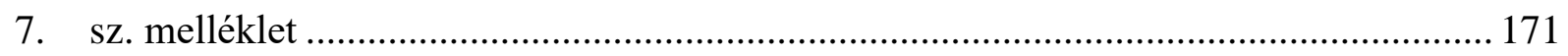

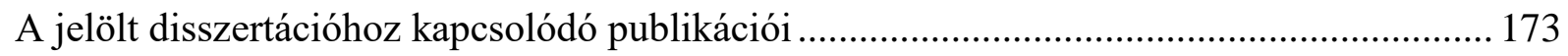




\section{Bevezetés}

A látáson alapuló észlelés a környezet érzékelésének alapvető formája, ugyanakkor a világban való tájékozódás és a kommunikáció eszköze is. A vizuális alkotások létrehozása egyidős az emberiséggel, történeti jelentősége vitathatatlan. Az esztétikailag meghódított valóság vívmányai folyamatosan, vég nélkül áramlanak a mindennapi életbe, alakítva az esztétikai érzéket, ízlést (Arnheim, 1954/2004, 1969, 1974/1979; Horányi, 2001, 2003a; Miorzeff,1999).

A vizuális kultúra fogalma magában foglalja a vizuális müvészetek alkotásait és a nem müvészi igénnyel létrejövő, de vizuális úton befogadható tárgyakat és jelenségeket egyaránt. A vizuális kultúra jelenti tehát mindazt a tudást, hiedelmet, müvészetet, hagyományt, valamint mindazokat a képességeket, készségeket, melyek a látáshoz kapcsolódnak, látás útján fogadhatók be (Helmich és Szántó, 2004). A vizuális kultúra jelentősége a digitalizációval, a digitális kommunikációs formák elterjedésével megnövekedett (Nyíri, 2008; Kárpáti, 1993; Tóth-Mózer és Kárpáti, 2016). A rendkívül gyorsan változó, szimbólumokban gazdag gépiképi kultúra a társadalom széles rétegét érinti (Simon, 2015). Ebből adódóan egyre nagyobb feladatot jelent ezt a heterogén világot leképezni úgy, hogy a befogadó számára értelmezhető legyen (Töreky, 2002).

A vizuális kommunikáció a vizuális kultúra része. A vizuális kommunikáció merít az autonóm müvészeti nyelvből, de jól elkülöníthető tőle, mivel az ember, mint társas lény gyakorlati (nem autonóm, hanem alkalmazott) kommunikációs elvárásainak felel meg és ezek alapján formálódik (Kepes, 1979; Nyirri, 2002; Terestyényi, 2005). A vizuális kommunikáció tudományterületté válása napjainkban is tartó folyamat, meghatározása eltérő megközelítésekben és tartalmakkal jelenik meg, különböző definíciók léteznek (Lester, 2006; Smith, 2005; Horányi, 2006; Horányi és Szépe, 1975/2004). Rosengreen (2000/2004) rendszerében a közös tudás gyarapítását szolgáló közlések jelentik a kommunikációt, melyen belül a nem verbális kommunikáció részét képezik a vizuális kommunikáció elemei: a grafika, a festészet, a szobrászat és az építészet (Rosengreen, 2000/2004). Kepes (1965) szerint minden olyan ember alkotta és kommunikációs szituációban megjelenő üzenetfajtát, amit a szemünkkel érzékelünk, vizuális üzenetnek, tekinthetünk, mely üzenetek által létrejövő kommunikáció a vizuális kommunikáció (Kepes, 1965). A tevékenység oldaláról megközelítve, „a vizuális kommunikáció olyan közlést jelent, amely eszközeit és jelrendszereit a látható világból veszi, illetve amely a vizuális tevékenységben nyilvánul meg" (Zombori 1995, 128.o.).

A különböző megközelítéseket figyelembe véve és összegezve a vizuális kommunikáció olyan képi közlést jelent, melyben a vizuális üzenet természetes vagy mesterséges, nem feltétlenül müvészi igénnyel kialakított, információt tartalmazó tárgy vagy kép, és az üzenet közvetetten vagy közvetlenül, direkt vagy indirekt módon egyaránt eljuthat a befogadóhoz. Az értekezésben részletesen ismertetjük a vizuális kommunikáció értelmezéséhez szükséges elméleti kereteket, melyben figyelembe vesszük a verbális közlések kapcsán képeket is elemző kommunikációelméleti kutatásokat (Imdahl, 1993, 2002; Pléh, 2003; Rosengren, 2004), a vizuális percepció és a képi kifejezés fejlődésével kapcsolatos kutatásokat is (Sekuler, Blake, 2000; Schuster, 2005).

A vizuális kommunikációs képesség definiálása szintén több elmélet bemutatásával történik. A vizuális képességrendszer értelmezése és standardizált értékelése az 1960-as években kezdődött, mely rendszernek egy részét a vizuális kommunikációs képesség alkotja. Változatos megközelítések jellemzik (Benköné, 1964; Gerö, 1973/2007; Drahos, 1988; Feuer, 2000; Kárpáti, 2001, 2005, 2009; Kárpáti és Gaul, 2011). Az értekezésben szereplő vizuális kommunikációs képesség meghatározásához egy korábbi kutatás széles szakértői konszenzuson alapuló és számos empirikus vizsgálattal igazolt vizuális képességrendszerét 
vettük alapul (Kárpáti és Gaul, 2011)1, mely rendszert a 6.1. fejezetben részletesen ismertetjük. A képességrendszerhez tartozó részképességek együtt alkotják a vizuális alkotó és befogadó képességet. A vizuális kommunikáció helyzeteiben a képességrendszer részképességeinek egy csoportja aktiválódik. Ez a képességcsoport adja kutatásunk tárgyát. A vizuális kommunikáció képességrendszerének vizsgálatát a kutatók túlnyomó része felnőttek viselkedésének elemzésével vizsgálta, az értekezésben ismertetett empirikus kutatás újdonsága, hogy gyerekek és fiatalok körében valósult meg. Olyan képességek vizsgálatával foglalkozunk, melyek szükségesek a mindennapi vizuális világ jelei közötti eligazodásban és a munka világában egyaránt. Bár a vizuális kommunikáció képességrendszerének területéről vizsgálataink csak egy szük területet fednek le, de ez a terület azonos a vizuális nevelési tantervi anyagával, értékelési eljárásaink és eredményeink ezért közvetlenül segítik a rajztanítási innovációt.

A NAT (Nemzeti alaptanterv 2012) így határozza meg a Vizuális kultúra tantárgy a kutatásomhoz kapcsolódó tanítási céljait: „azon képességek, készségek fejlesztése, ismeretek átadása, amelyek a vizuális kommunikáció magasabb szintü műveléséhez, a látható világ használatához, alakításához, a kreativitás fejlesztéséhez szükségesek" (Magyar Közlöny 10635 166.o. $)^{2}$ A tantervi elöírások teljesülésének vizsgálatában a vizuális kommunikációs képesség csoportjának pedagógiai értékelése megoldatlan, a tantervi követelmények teljesülése nem állapítható meg egyértelműen (Kárpáti és Gyebnár, 1996; Sándor, 2003). Kutatásunk ezért hiánypótló, az értékelési kultúra gazdagítása és mérőeszközök fejlesztése hosszú távon járulhat hozzá a vizuális nevelés minőségének javításához.

A disszertáció 1. fejezetében közöljük a kutatás céljait és hipotéziseit, melyek az elméleti részek tartalmaiból következnek Értekezésünk következő, elméleti részében bemutatjuk a vizuális kommunikáció meghatározásához vezető elméleteket, definiáljuk az értekezés tárgyát képező fogalmakat és meghatározzuk a vizuális megismerés formáit, illetve elhelyezzük köztük a vizuális kommunikációs képesség helyét. Leírjuk a vizuális alkotó és befogadó képességeket, bemutatjuk a képesség fejlődését leíró modelleket, valamint a vizsgált korosztály eddigi kutatások által feltárt képi közléseinek sajátosságait. A harmadik részben rövid történeti áttekintést adunk a vizuális kommunikáció szerepéről a nevelés történetében, és összefoglaljuk a Nemzeti alaptantervben és a Kerettantervben a vizuális kultúra tantárgy keretein belül a vizuális kommunikációhoz kapcsolódóan napjainkban deklarált célokat, követelményeket. Ugyanebben a részben kerül sor a vizuális képességek mérési hagyományainak és lehetőségeinek bemutatására.

$\mathrm{Az}$ empirikus kutatást ismertető részekben összegezzük a kutatás előzményeit. Ismertetjük a kutatás során kialakított taxonómiát és kialakításának menetét. Évfolyamonként elemezzük a vizuális kommunikációs képességet mérő tesztek validitását, pszichometriai jellemzőit és vizsgáljuk a kutatás során kialakított képességstruktúra és a teljesítmények alapján képezhető struktúra illeszkedését. Az empirikus rész végén ismertetjük a vizuális kommunikációs képességet mérő teszteken elért teljesítmények és a háttérváltozók összefüggéseit. Végül összefoglaljuk, milyen tanulságokkal járnak vizsgálataink a képesség fejlesztői és kutatói számára, és milyen további vizsgálatok szükségesek a képesség teljes spektrumának feltárásához.

\footnotetext{
${ }^{1}$ TÁMOP 3.1.9./08/1 Diagnosztikus mérések fejlesztése

2 110/2012. (VI. 4.) Korm. rendelet A Nemzeti alaptanterv kiadásáról, bevezetéséről és alkalmazásáról http://ofi.hu/sites/default/files/attachments/mk_nat_20121.pdf
} 


\section{Elméleti keretek}

Az értekezés fókuszában a vizuális kommunikációs képesség áll, ezért ebben a részben arra törekszünk, hogy minél alaposabban meghatározzuk a hozzá kapcsolódó fogalmakat. Összegezzük a vizuális kommunikációról szóló elméleteket, és röviden jellemezzük a képi fordulatot,(Pictoral Turn), melynek során napjainkra a vizualitás központi szereplöjévé vált a diszciplínáknak és a hétköznapoknak egyaránt. Ezután számba vesszük a képi gondolkodás kortárs megjelenési formáit és müfajait, kitérve ezek kommunikációs jelentőségére is.

\subsection{A képi fordulat}

A 20. század végén kibontakozó „képi fordulat” (Mitchell, 1994), vagy „új képkorszak” (Peternák, 1989) minden eddiginél nagyobb kihívás elé állítja a vizuális kultúrával foglalkozó szakembereket (pedagógusokat, kutatókat, müvészeket egyaránt). A digitális médiumokban az egyediség értékét megkérdőjelező, közösségi tereken létrejövő, a mindennapi életre reflektáló, korosztálytól független, szimbólumokban gazdag vizuális alkotások, melyek a vizuális müvészetek számos alapvető jellemzőjét kérdőjelezik meg. A virtuális világban épülő képi kultúra alapvetően különbözik a korábbi, stíluskorszakokként definiált müvészeti korszakoktól. A következőkben röviden áttekintjük, hogyan alakult ki és mit jelent a képi fordulat, mely alapvetően meghatározza kutatásunk kontextusát és egyben alátámasztja relevanciáját.

A látás jelentősége az emberiség történelmében az evolúciótól napjainkig vitathatatlan. A látás fontos volt a táplálékszerzésben, a veszélyek elkerülésében és a csoporton belüli együttmüködésben. Nyíri (2012a) szerint az emberi gondolkodás és kommunikáció elsősorban képies, vizualitásra épül, hiszen az arcjáték, a taglejtések nyelve megelőzte a szavakra épülő kommunikációt (Nyíri, 2012a). Bickerton (1992) elmélete szerint a nyelv kialakulása szoros összefüggésben van fejlett látásunkkal. A látással szerzett információk feldolgozása idézte elö, hogy a megnövekedett emberi agyban kialakult a magas szintü kategorizálás képessége. A környezetünkről alkotott belső kép, (mentális reprezentáció), az emberi gondolkodás és verbális nyelvet megelőző állomás volt, az ember kommunikációs képességének gyökere. A tudásrögzítés ősi formái szintén képiesek, gondoljunk a barlangrajzokra vagy a később kialakult képírásokra és ideogrammákra ${ }^{3}$. Az írásbeliség előtti elbeszélő nyelv tehát metaforikus, képekből táplálkozik és képeket táplál. Ezt a közvetett kommunikációt értelmezhetjük időben távoli kultúrák és társadalmak között is. Az elmúlt évszázadok, évezredek képi üzeneteit ma is értjük, illetve érteni véljük, és a képi jelek interpretációja alapján hipotéziseink vannak az üzenetek tartalmáról. Az egyiptomi hieroglifákat el tudjuk olvasni, feltételezéseink vannak a prehisztorikus korból származó sziklarajzok vagy megalit építmények társadalmi jelentőségéről és a mindennapi élethez kötődő, tudományos, illetve vallási üzenetiröl is (pl. Stonhenge) (Morris, 1997).

A képek viszonylagos háttérbe szorulása az írott kommunikáció kialakulásával vette kezdetét. Az alfabetikus írás előnye, hogy már gyermekkorban könnyen elsajátítható, és számos nyelvben egyértelmü hang-jel megfeleltetésen alapul. Az ábécé egyszerüségének köszönhetően az írás mindennapossá lett. Az írásos kommunikáció a könyvnyomtatás elterjedésével a beszéd után legelterjedtebb üzenetközvetítési formává vált, és a szöveghez képest a képek alárendelt, illusztratív funkciót kaptak. A képek kommunikatív szerepe háttérbe szorulása a könnyebben elsajátítható és egyértelmübb írással szemben technológiai, okokra is visszavezethető. Amíg nem volt lehetőség a képek egyszerü és olcsó gépi sokszorosítására, a képi üzenetek eröteljesen torzultak (Ivins, 1954/2001). Még a könyvnyomtatás első évszázadaiban sem voltak alkalmas eszközök egyedi tárgyak pontos

\footnotetext{
${ }^{33}$ Ideogramma olyan írásjel, amely (a betüktől eltérően) nem valamely hangot, hanem fogalmat jelöl (pl. a kínai és az óegyiptomi írásban).
} 
ábrázolására (Nyíri, 2012b). Mindebből következően Platón korától kezdve az oktatás és a tágabb értelemben vett müvelödés természetszerüleg szövegcentrikus volt (Havelock, 1963/1994). Ugyanakkor maga Platón is bírálja az alfabetikus írást, szerinte az írott szöveg nem interpretálható szabadon (kevéssé interaktív), és ezért kevesebb információt hordoz, mint a kép (Nyíri 2001a).

A verbalitás meghatározó szerepe mellett azonban a képiség folyamatosan jelentős szerepet töltött be a filozófiai gondolkodásban. A képek jelentésének és jelentőségének vizsgálata végig kíséri a kultúrtörténetet (Szabó és Kardos, 2014). Arisztotelész az emlékezetet, mint a képek birtoklását definiálja és szerinte a gondolkodásban ugyanaz az érzelem jelenik meg, mint képek, ábrák rajzolásával. A gondolatokat nem csak szavakkal fejezhetjük ki, hanem bármivel, ami elegendő, az érzékek által észlelhető megkülönböztethető jegyeket reprezentál (Bacon, 1605/1893). Locke, Berkely és Hume számára egyértelmü volt, hogy az ideák (a világot alkotó dolgok, személyek és képzetek) valójában mentális képek. Wittgenstein (1989) szerint azonban a képek önmagukban nem hordoznak jelentést, azaz a szavakhoz képest alárendelt szerepet töltenek be, és sajátos értelmüket csak használat közben nyerik el (a képek használat-elméletéröl vö. Nyíri, 2002). A kognitív pszichológia keretei között kibontakozó képiség vitáig azonban a képi gondolkodást előtérbe helyezők kisebbséget alkottak (Paivio, 1971; Danasio,1994; Neisser, 1967/2014). Mivel ezek az elméletek igen fontosak a vizuális kommunikációs képesség szabatos leírása és részképességeinek értékelése szempontjából, a 2. fejezetben számos képiséghez, azon belül a vizuális kommunikációhoz kapcsolódó elméletet, nézetet ismertetünk majd.

A fénykép megjelenése alapvetően megváltoztatta a képek szerepének megítélését. A valósághüség, mint érték és a pontos leképezés, mint müvészi feladat fokozatosan háttérbe szorult. A film és a televízió elterjedése meggyorsította ezt a folyamatot. A technika fejlődésével egyre nagyobb és változatosabb eszköztár áll rendelkezésünkre a képek megalkotására, reprodukálására, sokszorosítására, terjesztésére. A számítógépes grafika alkalmazásának elterjedése egyértelművé teszi a mủvészi, tudományos és hétköznapi vizuális nyelv térhódítását. Nyíri (2000a, 2001b, 2012a) az 1970-es évektől beszél egyfajta képi fordulatról, mely tetten érhető a pszichológiában, a filozófiában és a neveléstudományban egyaránt. „Amint a közvetlenül vizualizálható jelentésü egészen konkrét szavak területét elhagyjuk, metaforákban kezdünk beszélni. Viszont metaforákban beszélve is egy eredetileg képi logikát követünk. A képek háttere nélkül a szónyelv egyáltalán nem látszik müködőképesnek.” (Nyíri, 2007.7. o.) Mitchell (1995) 1992-ben használja elöször a „Pictural Turn" (képi fordulat) kifejezést. A képek egyre szélesebb körü alkalmazásával, és a manipulálás megjelenésével a „vizuális pedagógia” (a szemléltetéssel értelmezett tudás) nem csupán didaktikai módszer, hanem a valóság közvetítésének elemi eszköze lett (Nyíri, 1995, 2012a). Az internet és mobilalkalmazások nem csak technikájukban újszerüek, hanem az üzenetmegosztás és interakció lehetőségeinek megteremtésében is. A küldő és a fogadó közötti térbeli, nyelvi és kulturális távolság nem jelent akadályt. Mindemellett a képek nyelve a digitális képalkotás eszköztárának finomodásával alkalmassá válik elvont gondolatok közlésére, müvészi hatások elérésére is.

A 20. század végétől az írott nyelv csökkenő dominanciáját, az új vizualitás kialakulását tapasztaljuk (Neisser, 1967/2014). Az utóbbi évtizedekben a könyv, a napilap, magazin, reklám és egyéb nyomtatvány egyre színesebbé és egyre gazdagabban illusztrálttá vált: a nyugati ember képéhsége megteremtett a modern tömegmédia gazdag vizualizációs eszköztárát (Kolta, 2003; Kittler, 2005). Ahogyan a 16. században elterjedő, sokszorosított grafika is megváltoztatta a kortársak képi világát, bővítette a képek funkcióját, úgy alakítják a 20. század elejétől képbefogadó folyamatainkat a képzőmüvészeti könyvek színes nyomatai, és az önálló múfajjá váló reprodukció. Mára a hálózaton elérhetők a világ nagy múzeumainak anyaga. A médiahasználat bővülésének, változásának következtében gyakorlatilag bárki 
számára elérhetővé vált mindaz a képanyag, amit a képteremtő kezdeteitől máig - bárhol a világon - az emberiség létrehozott (Bubik, Simon, 2016).

A képekhez való könnyebb hozzáférésnek számos hasznos képességfejlödési következményét is tapasztalhatjuk. Mára egyértelmüvé vált, hogy az elvont szimbólumok formális láncolatából álló beszédhez képest a képek használata mondanivalónkat természetesebbé és hatékonyabbá teszi. Nyíri (2000b) szerint három jelentős változás figyelhető meg. Egyrészt, joggal feltételezhetjük, hogy a mentális képalkotás képessége napjainkban gyorsabban fejlődik, mint korábban. Másrészt, a képekkel való foglalatosság által az emberek olyan gazdag tapasztalatokra tesznek szert, amely példátlan az emberiség eddigi fejlödésében. (Egy példa erre: az illusztrációból új kutatási eredményeket hozó módszerré válik a tudományos vizualizáció.) Harmadszor, a számítógépes alkalmazások a könnyü képkészítés lehetőségeivel mindennapossá tették a korábban komoly kézügyességet és költséges eszközöket kívánó képi kommunikációt.

A vizuális nyelv elterjedéséhez kapcsolódóan a tudásszerzés mintázatai is megváltoztak, de ezt a folyamatot most nem részletezzük. A témánk szempontjából csak annyit fontos itt megemlíteni, hogy a formális iskolai intézményeket egyre inkább felváltják a nyitott müvelödés virtuális környezetei (Csapó, 2002b). Ezek a változások számunkra azért fontosak, mert magukkal hozzák az írni-olvasni tudó társadalom képi kommunikációs szükségleteinek és ezzel együtt a képiséghez való viszonyának változását. A digitális kommunikációban domináns szerephez jutnak a képek, és ez a kommunikációs környezet befolyást gyakorol az oktatásra-nevelésre is. A tanítási-tanulási környezet része a számítógéppel közvetített képi kommunikáció. A közeg, ahol a gyerekek játszanak, kommunikálnak, szórakoznak és tanulnak egyre inkább azonos azzal a világgal, melyben a felnőttek is dolgoznak, kommunikálnak és tanulnak.

Az internet „Szerves tanulási környezetet” hozott létre (Nyíri, 2008). „Amit a mai oktatáselmélet legígéretesebb törekvései a „nonformális tanulás” és ,atipikus tanulás/munka” kifejezésekkel jellemeznek, az az emberiség történetének túlnyomó része során éppenséggel természetes és jellegzetes tanulásnak számított. Ma, úgy tünik, ideje újragondolnunk Dewey-t. Ha az ő érve az volt, hogy szükségünk van mesterséges oktatási környezetekre, mivel elmúlt az a kor, amikor a fiatalok mintegy a felnőttek világába belenőve spontán tanultak - úgy ez a helyzet mára még égetőbb szükségletté vált. A közeg, amelyben a gyermekek játszanak, kommunikálnak és tanulnak, egyre inkább azonossá lesz azzal a világgal, amelyben a felnőttek kommunikálnak, dolgoznak, üzletelnek, szórakoznak és tanulnak. Az internet félreismerhetetlenül egyfajta szerves tanulási környezetté válik." (Nyiri, 2009) ${ }^{4}$.

A virtuális tanulási színtereken az írott szöveg linearitásával szemben más, képi struktúrákat helyeznek előtérbe (Ong, 1982). A digitális szövegek ugyanakkor kevésbé koherensek, mint a papíron megjelenők, mivel ritkán látjuk egyben a szövegeket. A képernyőn megjelenő szöveget, ha az egy képernyőnyi méretnél hosszabb, egy adott pillanatban csak részleteiben érzékeljük, ezért részesítik sokan elönyben ma is a nyomtatott szöveget (O'Hara,Sellen és Harper, 2001). Az elérhető és releváns dokumentum vagy akár csak egyetlen hosszabb dokumentum szinoptikus szemlélete (azaz a dokumentumot egyben látó szemlélete) az elektronikus felületen nem lehetséges, illetve nehézkes. Segíti az eligazodást, amennyiben az írott szöveget több képernyőn vehetjük szemügyre. Éppen ezért, a 7.3. fejezetben ismertetett, az értekezés tárgyát adó vizuális kommunikációs képességet mérō tesztek feladatait úgy szerkesztettük, hogy egy feladat egy képernyő felületet foglaljon el, ezzel kiküszöbölve az említett problémát.

A képernyőn megjelenő szövegben való tájékozódást jelentősen javíthatja az illusztrációk jelenléte. A képek könnyebbé teszik eligazodásunkat a virtuális könyvtárakban

\footnotetext{
${ }^{4}$ http://ofi.hu/tudastar/iskola-informatika/nyiri-kristof-virtualis
} 
is. Túlmutatva illusztratív szerepükön, jelentéshordozó, információközvetítő funkciókat is ellátnak. Az elektronikus dokumentumokban, szemben a papíralapúakkal, könnyebben és olcsóbban egészíthetjük ki gazdag képanyag a szövegeket,. A kép és a szöveg együtt a leghatékonyabb az információ gyors és pontos átadásában (Maczó, 2010). A 21. században kialakultak és egyre inkább elterjednek a kép és szöveg együttesének új müfajai: az infodesign, az infografika és a multimédiás üzenet. Az infodesign elsősorban a környezetbe beépülve segíti a kommunikációt, az infografika kép és szöveg együttes alkalmazásával létrehozott információközlő ábrázolás, a multimédiás üzenetek pedig több médiumot felhasználva (kép, szöveg, hang, mozgás) töltik be információközvetítő szerepüket. Mindhárom müfaj területén komoly szaktudással rendelkező emberek érik el, hogy a képek könnyen érthetők és hatásosak legyenek. A szöveg, a kép, a hang és a mozgás arányát gondosan megtervezik, hogy minden könnyen befogadható, értelmezhető és elemezhető, értékelhető legyen (Bubik, Simon, 2016)

Napjainkban a tudományos eredmények terjesztésének és a tanulásnak is hatékony eszközei lehetnek az infografikák (Tufte, 2006; McCandless, 2010). Az infografikák őseinek tekinthetők azok az ábrák, térképek és diagramok, melyek egyértelmüek, mindenki számára ugyanazt jelentik, és ebben a felfogásban különböznek más képektől. Ilyen értelemben hasonlítanak az íráshoz. A fejlődéstörténete során az írás vált a logikus gondolkodás legpontosabban tükröző eszközzé (McLuhan, 1962/2001), hiszen a képeken nem lehet a logikus következtetések rendjét számon kérni. Ugyanakkor a képek több dolgot is képesek leírni, nem linerásan, egymás után, hanem egyszerre. Egy képen olyan gyorsan megláthatjuk a fontos információt és az összefüggéseket, hogy még el sem kezdhetnénk azt szavakba önteni.

A tankönyvekben még kevésbé elterjedt, de tudományos szakirodalomban, illetve az eredményeket és a népszerüsítő közleményekben számos képalkotó eszközt használnak abból a célból, hogy az áttekinthetetlen mennyiségü adatokból gyorsabban kirajzolódjanak az összefüggések. A tudományos célokra használt infografika körültekintő tervezést igényel (Cairo, 2012; Varga, 2012). Az egyes tudományterületek egyre gyakrabban alkalmazzák, illetve vizsgálják az új vizuális médiumokat és a velük kapcsolatos kommunikációs módokat: az elektronikusan-digitálisan közvetített hangot, a digitális mozgóképet, az összetett szerkezetü, nem lineáris szöveget, és a multimediális-interaktív hálózatokat (Barabási, 2008, 2010; Czúni és Tanács, 2011).

A 21. században kialakult új müvészeti irányzat, az adatmüvészet, szintén hidat teremt a müvészet és a tudomány között. Az adatokból a tudományos területeken használt különféle képalkotó eszközök segítségével automatikusan képződik a kép. Az így létrejövő alkotások a jelentésük ismerete nélkül is érdekesek, szépek lehetnek, hiszen igen látványos maga a folyamat is, ahogyan a betáplált adatok képekké, látvánnyá alakulnak. A müvészek az adatvizualizáció automatikus folyamatának bármelyik pontján beavatkozhatnak, hogy esztétikus alkotást hozzanak létre.

Mitchell (1994) használja elöször a Pictoral Turn (képi fordulat) kifejezést. Szerinte a képi fordulat lényege, hogy a képek egyrészt leképezik világunkat és identitásunkat, másrészt alakítják is azt (Mitchell, 1994). A kifejezés arra utal, hogy, hogy a képek felszabadulnak a szavak kötöttségei alól, és mint önálló tartalomhordozók jelennek meg az egyes tudományterületeken. A szavak dominanciájától elfordulva, a képek elsőbbsége felé fordul a kultúra (Nyíri, 2009; Arnheim, 1969, 1974). A képek egyre fontosabb szerepet játszanak nem csak a filozófiai, különösen az esztétikai diskurzusban, hanem a hétköznapi életben is. Erre hívja fel figyelmünket Crary (1999), amikor a képalkotás modern vívmányaira utal, mint például szintetikus holográfia, repülés-szimulátorok, számítógépes animáció, robotikus képfelismerés, müholdas térképek, mozgásdetektorok, virtuális valóság (VR) megjelenítő eszközök, mágneses- rezonancia spektrográfia. 
A 20. század végén egyre több tudományterületen alkalmazták a vizuális információközvetítő müfajokat. Az iskolákban az 1980-as évektől jelentek meg széles körben a kép alapú, digitális tananyagok, és az 1990-es években megindult a vizuális képességek új típusú rendszerezésére, a digitális képalkotás fejlesztése és értékelése is (Tóth-Mózer és Kárpáti, 2016). A képekre alapozott oktatási eszközök használata a képi fordulat korában nem csak didaktikai módszer, hanem ,a valóság közvetítésének elemi eszköze” lett (Nyíri, 2012a. 11.o.). A vizuális képességekről, azon belül a vizuális kommunikációs képességről a 3. fejezetben írunk részletesen. A következőkben összegezzük a vizuális kommunikáció, mint közlésmód értelmezésének különböző megközelítéseit és tartalmait.

\subsection{A vizuális kommunikáció helye a diszciplínák között}

A képi fordulatot leíró részben rámutattunk a vizuális paradigma összetett jelenségére, melyet jól illusztrál a 1. ábra. Az ábrán Horányi (2003a) áttekinti a vizualitás vizsgálatával foglalkozó tudományterületeket és szerzőket. Látható, hogy ebben a rendszerezésben a kép, a képről való tudás és a képhez való viszony van fókuszban, eköré szerveződve jelennek meg az egyes tudományterületek és szerzők. A kép kétféleképpen jelenik meg: egyrészt, mint tárgy, másrészt, mint egy tevékenység része. A vizualitást meghatározó elemek ezen az ábrán kiegészülnek a kommunikációval foglalkozó területekkel.

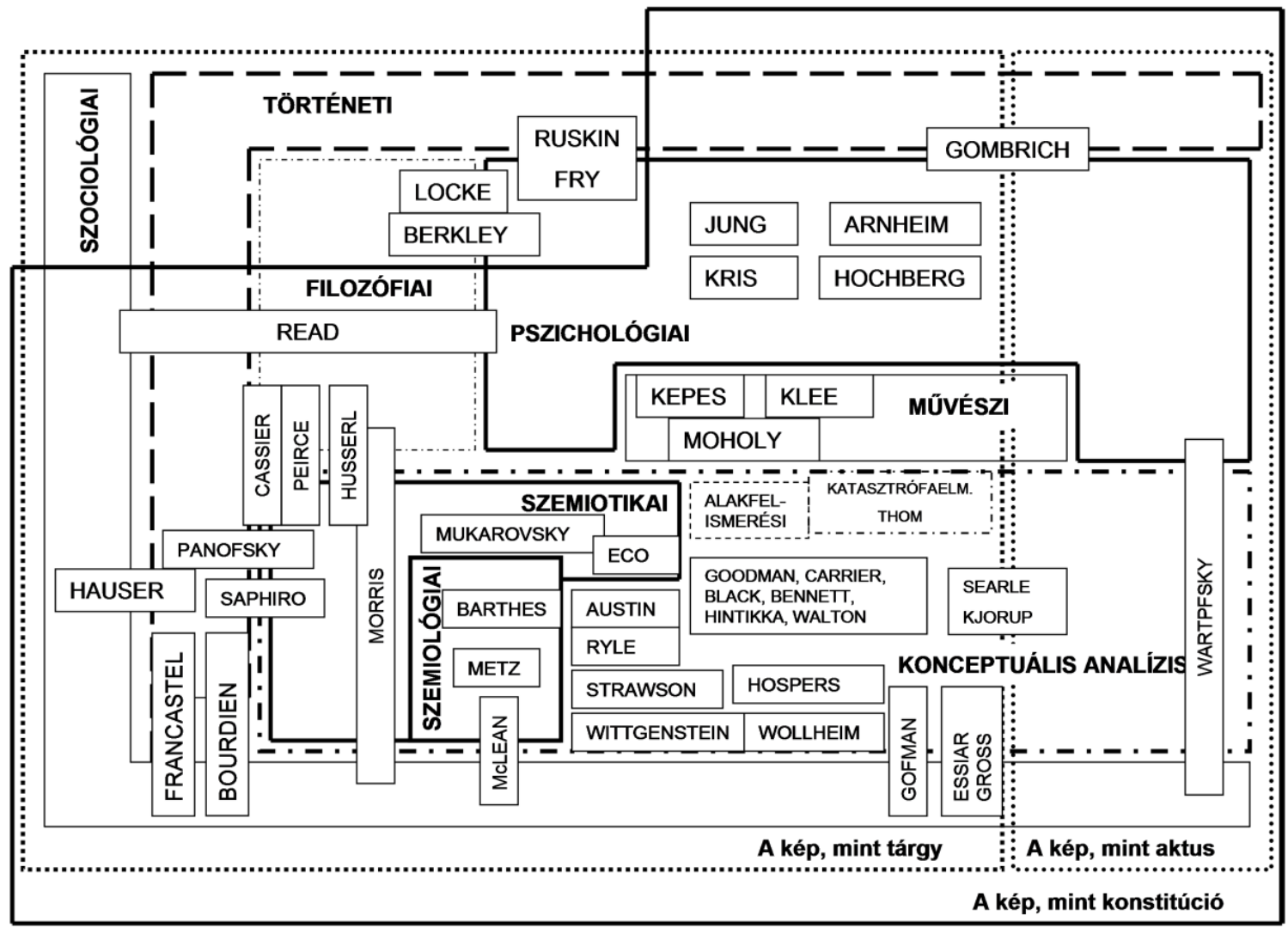

1. ábra A vizuális kultúra kutatásához tartozó tudományterületek (Horányi, 2003a, 16.o.)

$\mathrm{Az}$ ember alkotta, látható képek kommunikatív szerepének vizsgálata, a vizuális kommunikációról való gondolkodás folyamatosan bővülő kutatási terület, amely számos más tudományterülethez kapcsolódik. Ilyenek például: az etológia (Csányi, 1994, 2006, 2012), a 
kulturális antropológia (Kunt, 2003), a filozófia (Eco, 1998, 2010), az esztétika (Peternák, 1992, 1993), a kommunikációelmélet (Róka, 2002; Miklós, 1995; Antik, 2010), a pszichológia, különösen a befogadáselméletek (Arnheim, 2004; Duchowski, 2007), és a pedagógia (Kárpáti, 1995a, b; Kárpáti, 1996, Kárpáti és Gyebnár, 2013; Bakos, Bálványos, Preisinger és Sándor, 2000; Zombori, 1995; Szalontai, 1994; Bodóczki, 2002a, b). A kommunikáció fogalmi rendszere és kutatástörténete jellemzően a nyelvhez és a beszédhez kötődik (Terestyényi, 2006; Fercsik, 2006), ebböl adódóan számos, a verbális kommunikációhoz, kommunikációelmélethez kapcsolódó pontot fogunk érinteni a vizuális kommunikáció értelmezése során.

A vizualitásra épülő megismerés nélkülözhetetlen a világban való tájékozódáshoz. A látás érzékszervére támaszkodó, ennek lehetőségeit kiaknázó műveltség egyidős az emberiséggel. A látás útján szerzett ismeretek, illetve azok feldolgozási és reprodukálási módjai az emberi közösség létezéséhez elengedhetetlenek. A vizuális kommunikáció értelmezési kerete tehát igen széleskörü, magában foglalja az egyén és a társadalmi szerveződés szintjeit és a kommunikáció különböző színtereit egyaránt. A számos irány közül a továbbiakban a jelen kutatás számára releváns, a vizuális kommunikációs képesség értelmezéshez közelebb vivő területek eredményeit használjuk fel: a befogadás-elmélet, a pedagógia, a képzőművészet és a kommunikációelmélet eredményeire alapozunk.

\subsection{A vizuális kommunikáció fogalmi mezője}

A vizuális kommunikáció vizsgálata elválaszthatatlan a képzőmüvészettől, különösen annak 19-20. századi folyamataitól. A továbbiakban ezeket röviden összefoglaljuk, kiemelve a kommunikációhoz kapcsolódó elemeket. Ezután áttekintjük, hogyan, milyen szempontok között és milyen tartalmakkal jelenik meg a vizuális kommunikáció fogalma a kommunikációelméletekben, milyen fogalomkör kapcsolható hozzá, illetve milyen modellek alapján lehet értelmezni, és meghatározzuk az általunk elfogadott, a kutatásban használt definíciót. A vizuális kommunikáció meghatározása a kommunikációtudományi szakkönyvekben eltérő formában és tartalommal jelenik meg. A 2. fejezetben az egyre gyarapodó elméleteket rendszerezzük.

A vizuális kommunikáció, mint információközlési mód fogalma korábban jelent meg, mint a vizuális kultúra fogalma, annak ellenére, hogy ma már a vizuális kommunikációt a vizuális kultúra részének tekintjük (Elkins, 2003). A vizuális kultúra magában foglalja mindazokat az ember által alkotott, vagy környezetébe emelt dolgokat, melyek létrehozása és értelmezése a látáson alapszik. A vizuális kultúra részét képezi az érzékelhető tárgy- és jelenségvilág (humanizált természet, ember alkotta jelenségvilág), ennek a tárgyi és jelenségvilágnak létrehozása és használata, valamint a használatra vonatkozó vizuális alkotó és befogadó tevékenységekhez szükséges képességek, melyek a vizuális és kompetencia részei (Boehm, 1994; Miklós, 1995, Wagner és Schönau, 2016; Schönau, 2012). Az értekezés tárgyát adó kutatás ezekre a képességekre vonatkozik. A vizuális kommunikáció ennek a tágan értelmezett vizuális kultúrának a része. Ivins a vizuális kommunikáció fogalmát már 1952-ben megjelent könyvének címében szerepelteti (Ivins, 1954/ 2001). A vizuális kommunikáció diszciplína fejlődése ma sem lezárt terület, egyre több tanulmány foglalkozik vele (Lester, 2006; Smith, 2005; Horányi, 2003a, 2006), része a tanterveknek és a vizuális nevelés egyik központi tartalmává vált. (A magyar Nemzeti Alaptantervben (NAT, 2012) a három nagy vizuális nevelési terület egyike).

A korábban már említett képi fordulat (Pictoral Turn, Mitchell, 1994), vagy a képet tágabban értelmező, az egyszerü képi jeleket is magában foglaló kifejezéssel, az ikonikus fordulat (iconic turn, Boehm, 1994) leírásaiban a 20. század végi kommunikáció elégtelenségét emelik ki a szerzők. Szerintük az információk új formáinak megkülönböztetésére az eddig a képekkel való közlésre használt fogalmi apparátus alkalmatlan. Hasonlóan érvel Mirzoeff is, szerinte a képek dominanciája pragmatikus 
fordulatot jelent, és napjaink vizuális tapasztalatainak nagy része (mozi, multimédiás elemek, múzeum, közösségi terek) felülírja a korábban ismert, a képre vonatkozó vizuális információkat. (Miorzeff, 1999). A vizuális kommunikáció fogalmi mezőjében számos új elem is megjelenik, melyek a korábbi fogalmak újra definiálását is igénylik. Ilyen új elem például a képi írástudás (visual literacy), a vizuális kommunikáció elméleteihez tartozó kutatási terület, mely fogalmat John Debes vezetett be (Debes, 1969).

Debes egy új, fejlesztendő képességterületként tekintett erre a kompetenciára, és kutatására megalapította a ma is müködő, a területen élenjáró tudományos folyóiratot kiadó International Visual Literacy Association-t. A vizuális írástudás kutatása a képek mindennapi értelmezéséhez és megalkotásához szükséges kompetenciákra fókuszál (Cseh, 2015, Wagner és Schönau, 2016). Új fogalom a vizualizáció, a valóság leképezésének modern formája, amely olyan dolgok vizuális megjelenését jelenti, melyek lényegüket tekintve nem vizuálisak (Miorzeff, 1999). A vizualizációs képesség is a „visual literacy” része, a vizuális intelligencia alapdimenziója (Messaris, 2005). A vizuális írástudás alkotó eleme a multimédia üzenetek létrehozása és megértése is, amelyek a napjainkban egyre intenzívebbé váló médiakonvergencia - különböző kommunikációs infrastruktúrák (informatika, távközlés, média) összefonódása - során egyre fontosabbá válnak. Napjainkban összemosódnak az egyéni és a nyilvános kommunikációs színterek és alapvetően változtatják meg az üzenetek minőségét (Engberg és Bolter, 2014).

A vizuális kommunikációs folyamatban fontos szerepet játszanak a sürített üzenetek: a képi jelek és szimbólumok. Ezek egyik, ma is használt rendszerét Otto Neurath 1936-ban alakította ki. A „tipografikus képi nevelés nemzetközi rendszere” (International System of Typographic Picture Education, ISOTYPE, Neurath, 1936/1980) ma is része a képi közléssel foglalkozó szakemberek oktatásának. Bár még akkor még nem jelent meg a vizuális kommunikáció fogalma, mégis az ő munkássága mérföldkövet jelent a vizuális kommunikáció kutatásában. Nyomdokain indult el Rudolf Arnheim (1974/1979), aki a vizuális gondolkodás pszichológiai alapjait vizsgálta és az alaklélektan (Gestaltpsychologie) megalapozója volt. Az irányzat alapelve, amely szerint az egész alak észlelete több a részek egyszerü összegénél, és az egész a részekhez képest elsődleges, a vizuális kommunikációs folyamat megértésében is fontos (Arnheim, 1974/1979).

Kutatásunkban a vizuális írástudás részeként értelmezzük a vizuális kommunikációs képességet. Nem foglalkozunk a vizualizáció minden müfajával, kizárólag a korábban részletesen bemutatott, a magyar Vizuális Képesség Framework-ben meghatározott, szakértői konszenzussal az oktatás fontos részének tekintett képességelemekre koncentrálunk.

\subsection{Vizuális kommunikáció a képzőmüvészetben}

A vizuális kommunikáció egyik sokat vitatott sajátossága, hogy magában foglalja-e a az autonóm müvészeti alkotásokat is. A képi kommunikációs folyamatban a képzőművészet helye vitatott, ezért indokolnak láttuk alaposabban áttekinteni a témát, hiszen a vizuális kommunikációs képességet mérő tesztek fejlesztése során el kellett döntenünk, alkalmazzunke, milyen mértékben és minőségben a képzőművészeti alkotások a reprodukcióit.

A kommunikáció értelmezési keretében a leggyakoribb felosztás a verbális és nonverbális kommunikáció megkülönböztetése. A test, a testtartás, gesztusok, a mimika, a mozgások, a tekintet, a különböző érzelmi állapotok kifejezésére szolgáló testi jelzések a nonverbális kommunikáció formái közé tartoznak. Ide sorolható a tánc, a pantomim és a képzőművészet valamennyi ága is (S. Nagy, 2013). A müalkotásokkal zajló kommunikáció a mü és az egyén között létrejövő kapcsolatot jelenti. Ennek ellenére a kommunikáció szakirodalmában kevés azon tanulmányok száma, amely ezt a kapcsolatteremtést írja le, jellemzi. A müvészetpszichológia viszont intenzíven foglalkozik a néző és a mü kapcsolatának elemzésével (Halász, 1983; Farkas, 2003). Jelentős a képi kifejezés, a kép és a 
személyiség pszichológiai kérdéseivel foglalkozó szakirodalom is (Hekkert, Wieringen, 1995; Martindale, 1995; Mérei, 1995a, b; Berlyne, 1995; Halász, 2002; Halász, Hantos és Faa 2002; Schuster, 2005). A pszichoanalitikus elméletek szerint a vizualitásnak jelentős szerepe van a szubjektivitás kialakulásában, a képek hatékonyan szólítják meg éntudatunkat, mely által képesek hatást gyakorolni. A mủalkotás hatása akkor is eröteljes lehet, ha pontos jelentése megfoghatatlan. A müalkotások belső vizuális rendszerének fontos kommunikációs szerepe van. Például az európai kultúrában a képeket balról jobbra „olvassuk”, ezért meghatározó, melyik oldalra mi kerül. Hasonlóan befolyásolja a jelentést a fent és a lent, a formák elhelyezkedése, súlya, a vonalak iránya, a színek mélysége, a tónusok, illetve mindezek egyensúlya vagy egyensúlytalansága. A felületnek, az ecsetkezelésnek, a textúrának az észlelésen túl a mü és a néző közötti kommunikációban is kitüntetett szerepe lehet. A mü teljessége kommunikál a nézővel, de a hatást a részleteken keresztül éri el (S. Nagy, 2013).

A képzőmüvészet áramlatai meghatározták a rajztanítás tartalmait, fö irányait, melyek tendenciákat a 4.1. fejezetben tekintünk át. Itt most a 20. században a képzőmüvészetben végbemenő változások kommunikációs jelentőségéről szólunk. A 19. században kezdődött és napjainkban is tart a hagyományos müvészeti technikákat és tradíciókat megkérdőjelező és lebontó folyamat (Schneckenburger, Honnef, Ruhrberg, Fricke, 2005). A 19. század második felétől kezdve a fotó és a filmtechnika gyors fejlődése mellett kialakultak az új festészeti stílusok, hiszen ha a gép tökéletesen tudja reprodukálni a látványt, nincs értelme az ecsettel ugyanezt tenni. A festészet és a szobrászat elfordult a külvilág tanulmányozásától és másolásától. Kibontakoztak olyan irányzatok (kubizmus, futurizmus, op-art), amelyek például a tér-és időbeliséget is ábrázolni akarták. Az 1920-as évek Németországában elötérbe került az érzelmek, ösztönök, indulatok kifejezése, az ember belső világának kutatása és kifejezése (Micheli, 1978). Nemsokára megjelentek a különböző avantgárd ${ }^{5}$ irányzatok, melyek hatottak a müvészetoktatásra. Az addigi tanulmányozásra és másolásra épülő modellek nem voltak szolgálhattak többé a vizuális nevelés alapjául. A müvészeti ágak elkezdtek közeledni egymáshoz és napirendre került az élet és a művészet közötti határvonal eltörlése, a müvészet feloldása a mindennapokban. Ez jelentette azt a határvonalat, mikortól a képzőmüvészet beemelödött a direkt kommunikációs folyamatokba.

Az akadémiai béklyók széttörésével és az absztrakció megjelenésével a képi jelek megszabadulnak tárgyi kötöttségeiktől, a vizuális nyelv önálló nyelvvé érik (Király, 1992; Baudrillard, 1987; Kince, 1982; Miorzeff, 1999). 1919 és 1933 között a Bauhausban a kidolgozták az egységes vizuális nyelvet, mely kiterjedt a képzőmüvészeti alkotástól, az építészeti környezet alakításán át, a használati tárgyak tervezéséig (Haftmann, 1950/1988; Forgács, 1973, 2010). A második világháború után újabb irányzatok alakultak, melyeknek céljai között megjelenik a mindennapi élettel való kapcsolatteremtés és az arra való reagálás, a müvészet és az élet közötti határvonal elmosása. Új vizuális energiák szabadultak fel. A Pop art és a Fluxus mozgalom végletekig tágítja a hagyományos müvészeti eszköztárat. Az eseménymüvészetek megjelenésével a mozgás, mint vizuális esemény a valóság megismerésének eszközévé válik. Ezek az események új utakat nyitottak meg és nyitnak ma is a képzőmüvészetben, a vizuális kifejezés stílusainak és témáinak zavarba ejtő, gazdag világát alakították ki, illetve új értelmet adtak a hagyományos képi kifejezőeszközöknek (Schneckenburger, Honnef, Ruhrberg, Fricke, 2005; Bätschmann 1998a, 1998b, Moxey és mtsai.,1994).

A vizuális művészetek egyre újabb, szokatlanabb, kevésbé konvencionalizált egyediségre törekvő jeleket, jelkapcsolatokat teremtettek, kisebb térre szorítva így a közérthető vizuális nyelvet (Kunt, 1989). A kezdeti törekvésekkel ellentétesen, a folyamat során az alkotók elszigetelődnek a közönségtöl, a visszacsatolás, a vizuális alkotások keltette

\footnotetext{
${ }^{5}$ Az új, minden eddigi hagyománytól tudatosan eltérni akaró művészeti irányzatok összefoglaló neve a 20. század első felében.
} 
hatás így alkalmivá, korlátozottá és irányíthatóvá válik. A 20. század elején a képzőművészeti alkotások kommunikatív funkciói a század első felének túlnyomórész absztrakt irányzataihoz képest újra elötérbe kerültek. A hetvenes, nyolcvanas éveket jellemző konceptuális irányzatok és a társadalmi problémákra reflektáló Fluxus müvészeti mozgalom (Stegman, 2007) határozott kommunikációs szándékkal jelent meg.

Mindezek alapján indokoltnak tartjuk müalkotások megjelenítését a vizuális kommunikációs képességet vizsgáló mérőeszközökben. A képzőmüvészeti alkotások a vizuális kommunikációs képességet mérő tesztjeinkben, mint a vizuális jelek hordozói jelennek meg, a képzőmüvészet széles eszköztárát és annak kommunikációs elemeit nem célunk és nincs módunkban alkalmazni.

\subsection{A vizuális kommunikáció a kommunikációs elméletekben}

A következőkben a vizuális kommunikáció fogalmát a kommunikációelmélet területén belül értelmezzük. A kommunikációelmélet évtizedek óta elismert diszciplína, aminek a kutatások során számos meghatározása és modellje született: Stevens, 1950; Dance, 1957; Berelson, 1964; Miller, 1966; Cronkhite, 1976; Jacobson, 1960 (Futó, 1995). A modellek leegyszerüsített formában mutatják be a kommunikációt, abból a célból, hogy megtalálják azokat a tényezőket, melyek minden formájában benne vannak. Arra kerestük a választ, hogy melyik modell terjeszthető ki a vizualitásra.

A kommunikáció az egyik legfontosabb emberhez kapcsolódó összetett jelenség, melynek vizsgálatát az egyes kommunikációelméleti irányzatok eltérő módon képzelik el. A tranzakciós iskola és az interakciós modellek kiindulópontja, hogy a kommunikáció lényege, hogy egyszeri aktus (Barnlund, 1970/2003). A tranzaktív megközelítésekben csak az üzenet áramlását figyelik meg, a kontextus meghatározása nélkül, bár ennek szerepe meghatározó lehet. Az interakciós modellben nincs kitüntetett szereplö, a cselekvés a közlö és fogadó félre egyaránt jellemző. A tranzaktív és interaktív rendszerek statikusak, kevés tevékenységre redukálják a közlés és értelmezés, válaszadás folyamatát, ezért ezekbe a modellekbe nehézkes a vizualitás beillesztése.

A kommunikációt, mint folyamatot felfogó iskolák képviselői a kommunikáció társadalmi funkciójára helyezik a hangsúlyt. A vizuális kommunikáció társadalmi kapcsolatrendszerét Sándor (2011) ábrájával mutatjuk be (2. ábra). A társadalomra fókuszáló kommunikációs felfogás szerint a kommunikáció, mint a társadalmi valóság létrehozója és megtestesítője jelenik meg (Béres és Horányi 2001). A kultivációs iskola a szocializációs szerepet hangsúlyozza (Gerbner, 2002), a participációs iskola a kommunikációnak a problémamegoldásban betöltött szerepét hangsúlyozza (Horányi, 2007), míg a rituális modell fókuszában a kultúrateremtés és fenntartás van (Carey, 1992). Mindhárom modell fókusza sokrétü kapcsolatban áll a vizualitással. 


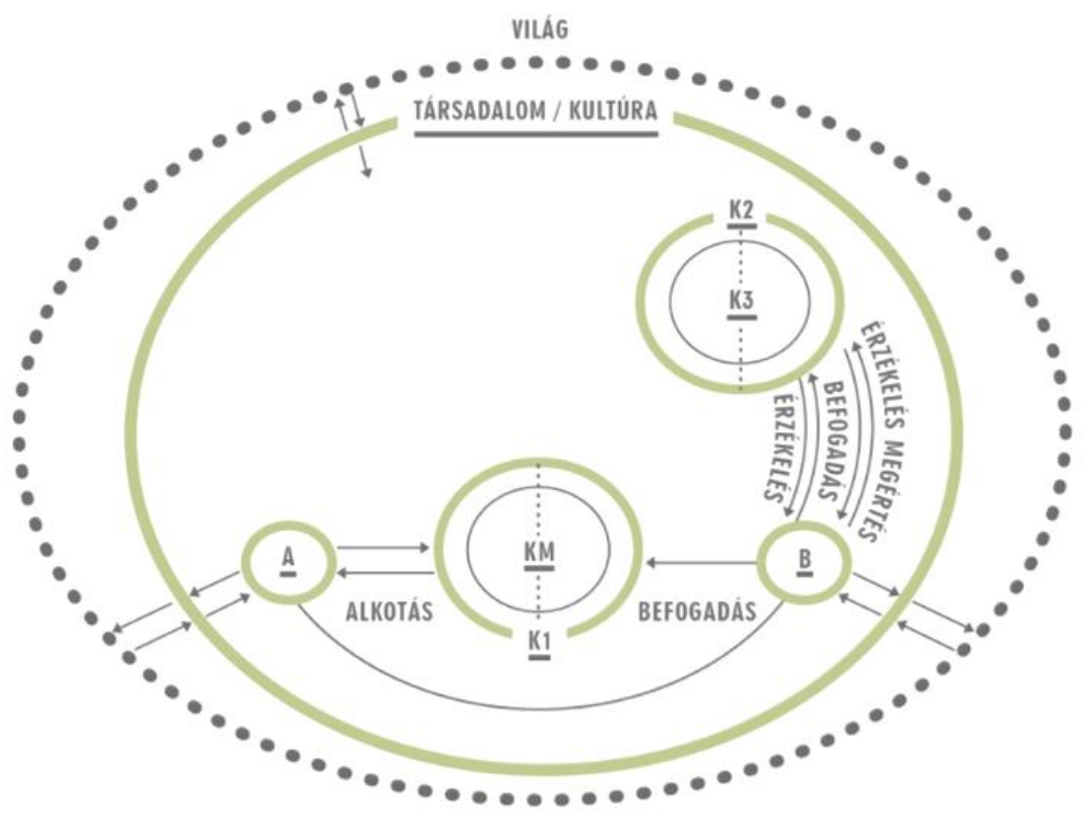

2. ábra A társadalmi keretekben zajló vizuális kommunikáció kapcsolatrendszere (Sándor, 2011, 33.o.) Rövidítések: A-vizuális alkotó tevékenység; B-vizuális befogadó/értelmezö tevékenység; KM-Kép-Mag; K1-az alkotói szándék szerinti kép;K2 - a befogadói szerepben látott kép;K3 - befogadói szerepben megértett kép

A kultivációs iskolához tartozó Gerbner (1956) modellje egy olyan általános képletét adja a kommunikációnak, melybe az észlelést is bevonja, így a látáson és vizuális észlelésen alapuló vizuális gondolkodást is fontos kommunikációs komponensként értelmezi. Későbbi vizsgálataiban (Gerbner, 2002) figyelembe veszi az egyéniség és a társadalmi-kulturális tényezők hatását is. Jensen (1995/2003) véleménye szerint, „a vizuális kommunikáció kutatásában ,a továbblépés útja nem a nyelvi modellen vagy a lehetséges jelek peirce-i formális taxonómiáján keresztül vezet. Inkább interdiszciplináris elméletépítésre van szükség." (Jensen 1995/2003. 208. o.). A digitalizáció is ezt az igényt támasztja alá, amennyiben a nyelvi és a képi kommunikációnkról való gondolkodás a digitális gépi-képi kultúra elterjedésével új alapokra helyeződik. A hipertext és az internet gyakran összemossa a két kommunikációs formát, kétségessé válik, hogy alkalmasak-e a korábbi fogalmaink a szöveg és a kép jellemzőinek leírására (Harnad, 2001). Ez a probléma felmerül akkor is, mikor a vizuális kommunikáció fogalmi mezőjének tágulásáról beszélünk (2.3. fejezet).

Amennyiben a kommunikációt a társadalmi funkciói felől közelítjük meg, és ebben a kontextusban keressük meg a vizualitás helyét, láthatjuk, hogy ezek a funkciók is összetettek. Szecskő (1994) a kommunikáció funkciójának nyolc területét különbözteti meg, melyek mindegyikében a vizualitás jelentős szerepet kap. Sándor $(2003,2011)$ kiegészíti ezeket a területeket a hozzájuk kapcsolódó vizuális színterekkel, melyeket az 1. táblázatban közlünk. 
1. táblázat A társadalmi funkciók és a vizuális színterek kapcsolata (Sándor, 2011, 38. old)

\begin{tabular}{cl}
\hline \hline társadalmi funkció & $\begin{array}{c}\text { a társadalmi kommunikációs funkciót szolgáló vizuális } \\
\text { kommunikációváltozat (vizuális (is) kommunikációs színtér) }\end{array}$ \\
\hline \hline tájékoztatás & \multicolumn{1}{c}{ a vizuális jelek a társadalmi élet minden területén a } \\
& $\begin{array}{l}\text { tömegtájékoztatás területén (a média egészét értve ez alatt, a } \\
\text { szóróanyagoktól a folyóiratokon át a televízióig és internetig) a } \\
\text { legkülönfélébb típusú képalkotások személyek és közösségek } \\
\text { információközlésének vizuális vonatkozásai, testbeszéd }\end{array}$ \\
\hline motiváció & vizuális reklám \\
& testbeszéd \\
& vizuális szemléltetés \\
\hline vita és eszmecsere & tudományos kutatások vizuális vonatkozása \\
& politikai kampányok vizuális arculata \\
\hline szocializáció & a település, a lakás (mint vizuálisan is ható élettér) és a tárgyak \\
& társadalmi csoportok és az egyén vizuális jellemzöi és \\
& jelrendszerei \\
& az egyén teste \\
\hline oktatás & vizuális szemléltetés \\
& vizuális tapasztalatok szerzése és ismeretközlés \\
& vizuális kompetencia, képességek, gondolkodás fejlesztése \\
\hline kulturális fejlödés & múzeumok, kiállítóhelyek, digitális gyüjtemények: az egész \\
& ember alkotta képi világ (benne a vizuális múvészetek is) \\
& kulturális termékek képanyaga (vizuális összetevöje) \\
\hline szórakoztatás & szórakoztató kulturális jelenségek vizuális összetevöi \\
& vizuális játékok \\
\hline integrálás & különbözö társadalmi csoportok testi-öltözködésbeli \\
& jelrendszere, a téma vizuális bemutatásai, dokumentumai \\
\hline \hline
\end{tabular}

A tevékenység oldaláról közelítve „a vizuális kommunikáció olyan közlést jelent, amely eszközeit és jelrendszereit a látható világból veszi, illetve amely a vizuális tevékenységben nyilvánul meg" (Zombori, 1995, 128.o.). A továbbiakban néhány példát sorolunk fel arra vonatkozóan, hol helyezkedik el a vizualitás a kommunikáción belül. Buda (2000) a folyamatra fókuszál, szerinte kommunikáció minden folyamat, melyben információátadás történik, függetlenül attól, hogy milyen jelekben vagy jelrendszerekben manifesztálódik az információ $(B u d a, 2000)$. Ebben a kontextusban az információ kerül a középpontba, tehát a képi információt tartalmazó közlés is kommunikáció. Kepes (1965) a vizuális üzenet meghatározása felől közelít a vizuális kommunikáció felé, egyúttal meghatározza a képi gondolkodás fogalmát. Kepes szerint minden olyan ember alkotta és kommunikációs szituációban megjelenő üzenetfajtát, amit a szemünkkel érzékelünk, vizuális üzenetnek tekinthetünk, a képi gondolkodás pedig a külvilágból érkező jeleket strukturálja, alakítja értelmes dolgokká (Kepes, 1965). Kepes tehát nem tesz különbséget müvészi és köznapi képek között, és az emberalkotta jeleken túl, a természeti látványoknak is kommunikatív értéket tulajdonít.

A kommunikációt definiáló tanulmányok többségében a kommunikációt verbális és nonverbális kommunikációra osztják fel, melyben a nonverbális kommunikáció a testbeszédet jelenti. A nonverbális kódok között a testmozgás, a szem- és az arcmozgások, valamint az érintés szerepel (Infante, Rancer és Womack, 1991).

A verbális és a nonverbális mellett, a vizuális kommunikáció a verbális szöveghez kötődően, mint a kommunikáció harmadik szintje jelenik meg Róka (2002) könyvében. 
Ugyanitt a nem verbális kommunikációhoz, mint a verbalitás kiegészítőjét sorolja fel a szerző a vizuális kommunikációhoz közvetlenül csatlakoztatható ikonika tudományát. A szerző szerint a nem verbális kommunikáció egy típusának tekinthetjük a tárgyakban, formákban rejlő szimbolizmust is, mely folyamatot ikonikának nevezzük, a szimbólumokat pedig ikonoknak. Az ikonok Róka meghatározása szerint sokfélék lehetnek, attól függően, ennyire konkrétan ábrázolják a tárgyat (bővebben az ikonikáról a 2.5. fejezetben írunk). Az ikonok lehetnek az emblémák, a divat kellékei, a közlekedési jelek éppúgy, mint a képzőmüvészeti alkotások (Róka, 2002).

Griffin (1991/2001) sem önálló területként tárgyalja a vizuális kommunikációt, csupán a szemiotikai fejezetben kap szerepet néhány kép vagy látvány a vizuális jel értelmében. Rosengren (2004) szerint a „kommunikáció valaminek a közlése, közzététele, amely által az ún. közös tudásunk gyarapodik." (Rosengreen, 2004, 13.o.). Rosengreen rendszerében kommunikáció egyik formája a nem verbális kommunikáció, melynek részeként említi a grafikát, festészetet, szobrászatot és építészetet.

Nyíri (2008) azt a felfogást képviseli, miszerint a gondolkodásunk elsődlegesen képek közegében zajlik, és csak azután szavakban. Különösen igaz ez a digitális képekre épülő 21 . században, mely technika alkalmas arra, hogy a gondolkodásunknak megfelelő inkább dinamikus képeket alkosson. A számítógép-software fejlődésének következtében a képek nyelve egyre jobban alkalmassá válik elvont gondolati kommunikációra.

A szakirodalomban (Searle, 2003; Terestyényi, 2006) létezik egy, a vizuális közlést a képekkel azonosító felfogás, amelyben az üzeneteket kizárólag képek továbbítják. Ebből következően a testbeszédet, testmozgást, mimikát és a gesztusokat nem tekintik vizuális kommunikációnak, mivel ezeket nem képként értelmezik.

A kommunikációelméleti szakirodalomban különbözőképpen jelennek meg a látáshoz köthető, a vizuális kommunikációhoz kötődő fogalmak. Számos kutató szerint ez egy önálló kommunikációs forma, amely a látáshoz kapcsolódik, (például képek, műalkotások, tárgyak, animációk befogadása, értelmezése) néhányan azonban a nem verbális kommunikáció egyik formájaként határozzák meg. Az itt bemutatott kutatás az első meghatározáshoz kapcsolódik: véleményünk szerint a vizuális kommunikációs képesség a vizuális képességrendszer önálló része, a verbális kommunikációval egyenértékü, sajátos közlési forma, amelynek megismerése és fejlesztése az Új Képkorszaknak nevezett 21. században különösen fontos. A következőkben összegezzük, melyek a vizuális kommunikáció tartalmát képező képek, tárgyak, látványok, és hogyan határozhatók meg ezek kapcsolatai.

Flusser (1992) szerint a képek jelentéssel teli felületek. Alkotójuk kiemel néhány információt és ezt a sík két dimenziójára szükítve jeleníti meg számunkra. Imaginációnak nevezi azt a jelenséget, hogy képesek vagyunk a világot néhány jellegzetes vonással megjeleníteni és ezeket a képeket befogadni. Az imagináció képességével állítunk elő és értünk meg képeket, ez által fejezzük ki a jelenségeket kétdimenziós szimbólumokkal, és ezeket a szimbólumokat leolvassuk (Flusser, 1992, 2005). Flusser a kétdimenziós képekre szúkíti a vizuális kommunikáció tartalmát.

Miklós Pál $(1980 ; 1995)$ a hétköznapi használati tárgyakat is a vizuális kommunikáció rendszerébe emeli. A szerző szerint a tárgy önmagában is megnyilatkozás pusztán azáltal, hogy megszerkesztették, felépítették, egyfajta szépség vagy funkció szerint kialakították. A használati tárgyaink mindegyike egy vagy több funkcionális struktúra tagja, ám a vizuálisan észlelhető tulajdonságaik a funkcionális strukturáltság mellett jelentést is közvetítenek felé, és így átkerülnek egy kulturális rendszerbe, mely rendszerben az információ, a tárgyi üzenetek folytonos áramlása kap domináns szerepet (Baudrillard, 1987).

A design, a forma üzenete, fontos kommunikációs eleme a tárgyaknak, mely egyrészt a társadalmi-gazdasági jelzéseket juttatja a termékbe, másrészt a gyártónak termékformában fogalmazott jelzéseit közvetíti a fogyasztókhoz. Erre a kétirányú kommunikációra épül 
napjainkban a reklámipar, mely szintén fontos terepe a vizuális kommunikációnak. A divat is a kommunikáció fogalomkörébe tartozik (Róka, 2002).

Terestyényi (2006) értelmezésében „nem minden vizuális, mimetikus vagy auditív produkció, nem minden képszerű dolog kommunikáció", hanem csak az a kép kommunikáció, amely információt közöl az ,ábrázolt dologról” (Terestyényi 2006 60.o.). Összegezve elmondhatjuk, hogy a vizuális kommunikációhoz köthető tartalmi elemek számos formában megjelenhetnek, szerzőtől, megközelítéstől függően. Kötődhetnek a hétköznapi tárgyi világhoz és a kétdimenziós képekhez egyaránt, valamint a képzőmüvészet, szobrászat és ipamüvészet alkotásai is részei lehetnek a vizuális kommunikációnak.

Összegezve vizuális kommunikációt a következöképpen értelmezzük: a vizuális kommunikáció a látás útján történő kommunikáció, melynek része az önértelmezés, kapcsolatteremtés másokkal és a világgal, valamint a látás útján történő probléma felismerés és megoldás a vizuális kultúra tárgy és jelenségvilágának direkt és indirekt úton történő használatával. A következőkben rendszerezzük a vizuális kommunikáció vizuális nyelvi jelkészletét, kódjait és struktúráját.

\subsection{A vizuális nyelvi tartalmak, vizuális kódok és struktúrájuk}

A vizuális üzenetek kódjai a vizuális alapelemek minőségei: a fény, szín, forma, felület, anyag, pont és vonal önmagukban is sokfélék. Ezeknek a minőségeknek az összetett viszonyai a kompozíció, szerkezet, dinamika, ritmus, figyelemirányítás, tér és idő ábrázolási módjai és ezek változatai együttes elnevezése hagyományosan a vizuális nyelv (Sándor, 2011). A vizuális nyelv elemeiböl épülnek fel a vizuális üzenetek többszörösen összetett kódjai. A vizuális üzeneteket meghatározzák az elemek közötti viszonyok, hierarchia és szerkezet. A vizuális elemekböl létrehozott kompozíciók rendezése során létrejött variációk és kombinációk által végtelen számú vizuális jelet és vizuális üzenetet hozhatunk létre.

A vizuális üzenet létrehozásában és értelmezésében a kulturális és egyéni meghatározottságnak rendkívül nagy szerepe van, ezért a vizuális jelek dekódolása bizonytalan. A vizuális kód lehet konkrét, absztrakt, ikonikus vagy szimbolikus. Például a kör forma jelentheti önmagát, jelenthet egy absztrakt geometriai alakzatot, lehet egy tárgy (kerék) stilizált, ikonikus képe, ugyanakkor számos szimbolikus jelentéstartalma is van (például a Nap, a tökéletesség, a teljesség jelképe).

A vizuális nyelv a látás nyelve, mely által a vizuális kommunikációban is létezik a zaj jelensége, azaz a látást zavaró bármilyen tényezők. Ilyen zajok lehetnek például a nem megfelelő fényviszonyok (túl sok vagy túl kevés fény), minőségi problémák, túl gyors mozgások, térbeli elhelyezkedés (rövidülés, takarás) vagy a befogadó látási képességeinek korlátai.

A vizuális üzenetek jelentős csoportját a képek alkotják. Minden kép tartalmaz információt, de a képi információ mennyiségének és a képi közlés minőségének mérése nehézkes. Az információ és a kommunikációs üzenet elkülönítéséhez Terestyéni (2006) meghatározását vesszük alapul. Az információ természetes jel, nem szimbolikus és nem kommunikatív. Például a színinformáció olyan természetes jel, amit dekódolni tudunk kellő tapasztalat birtokában (például a piros ribizli érett). Amennyiben a szín kommunikációs jel, azaz szándékolt közlés, szintén dekódoljuk, tanulás útján vagyunk képesek értelmezni. Nem természetes, hanem szimbolikus jel (például a közlekedési táblák piros színe). A jel alapterminus mindkét esetben (Hampshire, 2009).

A jel három fő tulajdonsága: rendszert alkot, társadalmi jellegü, jelentése van. A három tulajdonság egyúttal a szemiotika (jelek, jelrendszerek tudománya) fó ágait is kijelöli: szintaktika, pragmatika, szemantika. A szintaktika, azaz jelnyelvtan, a jelek kapcsolatrendszerével, a spontán és tudatos szabályokkal és konvenciókkal foglalkozik, tehát a jelek üzenetcélú kombinálásával. A pragmatika vizsgálja a jel és az emberek közti viszonyt, 
a jelhasználat gyakorlatával és történetével foglalkozik. A szemantika a jelentéstan, melynek középpontjában a jeleknek az általuk jelzett dolgokhoz való jelentésének vizsgálata van. Ebböl a szempontból különböztetjük meg az index, a szimbólum és az ikon jeltípusokat (Bálványos és Sánta, 1998/2003).

Indexről akkor beszélünk, ha a jel és jelentettje között oksági viszony van. Az index a legegyértelmübb jeltípus (például a lábnyom egy korábban arra járt élőlényt jelez). A szimbólum a jel és a jelentés közötti megállapodásszerü viszony. Ez a megállapodás kialakulhat lassan, akár évszázadok alatt (zászló, címer), spontán használat során (városszimbólum) vagy tervezési folyamatban (logó, közlekedési tábla). A szimbólum többnyire emberi szándék által keletkezik, de szimbólummá válhatnak természetes képződmények is (pl. Fuji hegy Japánban), valamint valós vagy képzeletbeli állatok, növények is (pl. kínai sárkány, gall kakas). Az ikon esetében a jel és jelzettje között hasonlóság van, az ikon formailag utal a jelzettre. Ikon típusú jel a piktogram.

Kepes szerint a vizuális nyelv kódja ikonikus kód (Kepes, 1979). A megismerési folyamatban és tevékenységben a vizuális nyelv nem ráépül a verbális nyelvre, hanem együtt jelenik meg vele. „A vizuális nyelv minden más kommunikációs eszköznél hatékonyabban képes a tudást terjeszteni. Segítségével az ember tárgyi formában fejezheti ki és adhatja tovább tapasztalatait. A vizuális kommunikáció egyetemes és nemzetközi: nem ismeri a nyelv, a szókincs vagy a nyelvtan korlátait; egyaránt megérthetik írástudatlanok és müvelt emberek. Tényeket és eszméket nagyobb mértékben és mélyebbre hatolva tud közvetíteni a vizuális nyelv, mint más kommunikációs eszközök. A statikusan verbális fogalmat a dinamikus képnyelv érzéki elevenséggel képes életre gerjeszteni. Egy adott vizuális kép befogadása egyúttal azt is jelenti, hogy a szemlélő szintetizálási folyamatban vesz részt. Az érzékelt kép tapasztalása egyúttal alkotó integrációs tevékenység. Lényeges ismérve, hogy az alakító képesség szerves egésszé formálja a tapasztalatot. Ez a formaadás alapiskolája, ami viszont formátlan világunk zürzavarában strukturális szempontból óriási jelentőségü."foglalja össze gondolatait Kepes György képzőművész és teoretikus (Kepes, 1979. 6. o.).

A vizuális üzenetek ikonikus kódját több szempont szerinti csoportosítja a szakirodalom (Futó 1995). A kódok között foglalkoznak anatómiai ábrákkal, térképekkel, és a statisztikában használt, vizualizált grafikonokkal, diagramokkal. A grafikonok és diagramok olyan összefüggéseket is mutatnak, melyek eredetileg nem vizuálisak, hanem például időbeli vagy logikai viszonyokat ábrázolnak (pl. családfák).

A képi közlést meghatározó vizuális nyelvhez közelíthetünk a funkció oldaláról is. Antik három meghatározó funkciót emel ki a képi közlés meghatározásában: gyakorlati tájékozódás, tudományos-technikai eszmék illusztratív szemléltetése, szubjektív képi ábrázolás (Antik, 2010). A vizuális kommunikáció funkciói alapvetően azonosak mind a személyközi, mind a tömegkommunikációban. Ugyanakkor a médium jellege módosíthatja a funkciókat, ami lehet: információátadás, meggyőzés, érzelmek kifejezése, kohézió, vagy szórakoztatás (Miklós, 1995; Horányi, 2003 b). A vizuális kommunikáció színterein (vizuális retorika, szemléltetés, tipográfia, prezentáció, infografika) más-más funkciót részesítenek előnyben, és ez jelentősen meghatározza az információ nyelvezetét.

A vizuális közlés esetén is a kommunikációs tartalomnak, céloknak és funkcióknak megfelelően alakítjuk ki az üzenetet, alkalmazzuk a vizuális nyelvet. A nem verbális és a vizuális kommunikáció kódjai történeti fejlődés eredményei és kultúra specifikusak. A képi közlés és annak értelmezése is, a verbálishoz hasonlóan, rendszerismeretet és tapasztalatot igényel. A vizuális nyelvet életterébe helyezve lehet érdemben vizsgálni. A vizuális nyelvi hatásokat befolyásolja maga az ember (biológiai, pszichológiai feltételei, nézőpontja, stb.), a társadalom és kultúra, az anyag és a komponált vagy nem komponált látvány (Rusbult, 1995; Gombrich, 1991/1999; Goodman, 1977). A vizuális kommunikáció szemszögéből vizsgált ember alkotta vagy természeti tárgyak (például Tokaj-hegy a térség szimbóluma), művészeti 
vagy dizájn és kézműves alkotások, épületek, stb. egyúttal a város vagy az ország szimbólumai is (például az Eiffel torony Párizs egyik fő szimbóluma). Az ilyen jellegü üzeneteket tanulás útján sajátítjuk el.

A vizuális nyelv nem nemzetközi, függ a kortól és a kulturális hagyományoktól. Egy kultúra alkotásainak értelmezéséhez ismernünk kell az adott kultúra vizuális nyelvi konvencióit. Egy-egy korszak, kultúra stílusát meghatározzák vizuális nyelvi konvenciói, melyek a különböző korok és kultúrák kommunikációs szükségletei szerint jöttek létre, valamint váltak szokássá és hagyománnyá (Bubik, 2013). Egy-egy adott kultúrát jellemzi, hogy a nyers, elsődleges látási érzékelés által kapott információk között mennyire képes differenciálni, milyen mértékig fejlesztette a vizuális nyelv értelmezési, feldolgozási és rendszerezési módozatait, az ismeretek milyen arányban kerülnek vizuális kódolásra. A kultúrához illeszkedő ismeretek rögzítése és tárolása, valamint átadása mennyire hatékony, milyen mértékben szükséges tudatosság vagy ösztönösség a vizuális jelek értelmezésében, ez szintén kultúránként különbözik. A társadalom szerkezetének fejlettségi fokától függ, hogy milyen csoportok és rétegek milyen mértékben részesülnek az értelmezési keretek ismeretében. Tehát jellemzi a társadalmat, hogy a vizuális kommunikációs rendszerek milyen mértékben szolgálják az egész közösség vagy egy réteg érdekeit (Kunt, 1989).

A müvészek kultúrájuk látásmódja szerint ábrázolják a világot, aszerint, ahogy a világ szemléletét maguk is tanulták. Ez a látásmód hagyományokra és megszokásra épül, és az egyéniség révén csak kismértékben változhat. Ez a változtatás is attól függ, hogy az adott kultúra mennyire fogékony-e rá (Bubik, 2013).

A hazai tantervekben ${ }^{6}$ képzőművészet helye a vizuális kommunikációban vitatott. Bár a képzőművészet a nyelv összes kommunikációs funkcióját betöltötte már, de a müvészet mégsem azonosítható a kommunikációval, hiszen nem ez az elsődleges célja (ld. 4.2. fejezet). A müvészet által létrehozott alkotások (festmények, álló- és mozgóképek, installációk)

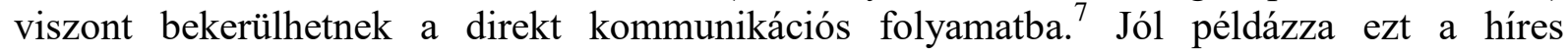
festmények átírásának és újraértelmezésének elterjedése, mint önkifejező, világot leképező eszköz (például a Mona Lisa alapján készült közösségi oldalakon megjelenő profilok).

A vizuális nyelvi elemek viszonylatai eredményezik a kifejezést. A képi kifejezés stílusát az egyéni beállítódás még tovább és nagymértékben befolyásolja (Piper, 1984). A vizuális kifejezés mélyen a kultúrába ágyazódik, csak hosszas spontán vagy iskolai tanulással sajátítható el, hogy egyes látványok kultúránként igen eltérö jelentést hordoznak (Chrystal, 2003).

6 51/2012. (XII. 21.) EMMI rendelet A kerettantervek kiadásának és jóváhagyásának rendjéről kerettanterv.ofi.hu/03_melleklet_9-12/3.2.13_vizkult_9-10.doc

7 A tesztfejlesztés során nem követtük a kerettanterv irányadását a képzőművészeti alkotások alkalmazását illetően. Úgy döntöttünk egyéb elméleti elveknek megfelelően, hogy a vizuális kommunikáció tesztekben felhasználunk képzőművészeti alkotásokról készült képeket. 


\section{A vizuális megismerés}

A vizuális megismerés tapasztalati szintje a vizuális percepció, a vizuális észlelés és érzékelés, az érzékszervek közvetítésével történő közvetlen viszonyulás a valóság jelenségeihez. A vizuális megismerés gondolati szintje a vizuális appercepció, mely a vizuális gondolkodást és alkotó látást foglalja magában.

\subsection{A vizuális képességek neurofiziológiai háttere}

A környező világot látásunkon keresztül értjük meg, valamint a kommunikációban, társas kapcsolatainkban, az információszerzés is jelentős szerepe van a vizualitásnak. A látás a szemmel való érzékeléssel jön létre, de látás a közvetlen megfigyelést, a szem használatát nem igénylő belső látás is (Sekuler, Blake, 2000). A külvilágból érkező ingerek 60-80\%-át látás révén érzékeljük, agyunk 40\%-a a látással foglalkozik. Az emberi szem nagy hatótávolságú, gyors adatátvitelt biztosít és alkalmazkodik a külvilág ingereihez.

Bár végtelen, egymástól nagyon különböző feladat végrehajtása függ a látástól, a legtöbbnek közös a kulcsmozzanata: a detekció, a tárgyak elkülönítése környezetüktöl. A következő mozzanat a diszkrimináció, a tárgyak megkülönböztetése. Ha még jobban szeretnénk pontosítani a látottakat, az azonositás folyamata megy végbe. Ez a három tevékenység hierarchikus rendszert alkot. A látás első szintjén sem csupán a fényképszerü retinaképnek az agykéregbe történő továbbítása, hanem információ-feldolgozás is történik (Pléh, 2003).

Az idegsejtek müveletei a világról szólnak, arról, hogy mi történik környezetünkben (Gross, 2004). Már a látás első szintjén is nagymértékü kivonatolás, lényegkiemelés, tömörítés folyik. Az észlelés komplexitása következtében, ha a színektől, mozgástól és mélységtől eltekintünk, a fennmaradó fizikai dimenziók akkor is jellemezni tudják a körülöttünk lévő tárgyak lényeges és tartós tulajdonságait. A látás második szintjén az orientációra vagy vonalirányulásra hangolt sejtekkel valósul meg a tárgyak látható kontúrjainak a kiemelésével a további szelekció. Ezek a sejtek egymással kapcsolatot létesítenek, és az egy tárgyhoz tartozó éldarabokat elkezdik összekapcsolni. Ez a tárgyfelismerésnek, a kategorizációnak az alapfeltétele. A szakirodalom külön fejezetekben tárgyalja a szín-, a minta-, a forma-, a tér-, a mélység- és mozgásészlelést (Sekuler, Blake 2000; Csépe, Györi, Ragó, 2008). A 20. század végére dőlt meg az a század közepén még elfogadott nézet, mely szerint a mintázatok látása, a forma, szín, tér és mozgás észlelése az agy egyetlen rétegében történik (Gross, 2004).

A 20. század utolsó évtizedeiben a látáskutatás úttörő eredményeket ért el (Julesz, 2000; Gross, 2004; Pléh, Kovács, Gulyás, 2003). A tudat jelenségei, ezzel együtt a vizuális percepció is visszavezethető a központi idegrendszeri funkciókra. Az agyban több vizuális terület aktiválódik, amikor a perceptuális élmény megváltozik, illetve kimutatható ugyanezeknek az agyi területeknek az aktivitása tényleges vizuális inger nélkül (Kovács, 2001). Kovács (2001) kísérletei bizonyították, hogy számos agyterület aktivitása szükséges a vizuális tudat kialakulásához. Például, amikor szemet megtévesztő, többértelmű ábrákat nézünk, egyszerre több vizuális terület aktiválódik az agyban, mint amit a látott kép indokolna. Bizonyította, hogy tényleges vizuális inger nélkül kimutatható ugyanazoknak az agyi területeknek az aktivitása, amelyek egy valóságos látvány hatására aktivizálódnak. Tehát a memóriánkból mindenféle fizikai inger nélkül előhívott tárgyak képe hasonló aktivitást idéznek elő a neuronok között, mint mikor valóságban látjuk a tárgyat (Kovács, 2001).

Gyakorlás hatására finomodnak az érzékek, a festés, rajzolás kölcsönhatásban van a látással, fejleszti azt (Gibson, 1969). A látás finomodásával a mübefogadás érzékenysége nő, a müalkotásokkal elmélyülten foglalkozó gondolkodás pedig új aspektusokat fedez fel és esztétikai élményként él meg másokat is (Schuster, 2005). A látás és vizuális képességek fejlődése kölcsönösen hatnak egymásra. A fogalmi gondolkodással párhuzamosan müködő 
képi gondolkodás is a látáson alapszik. Kutatások folynak arról, hogyan hatnak a müvészeti befogadás és a müalkotások a látás fejlesztésén keresztül más tudományágak müvelöire, például az orvosi diagnosztikára vagy a sportteljesítményekre (Krüger, Campheri, Smith, 2009; Naghshineh és mtsai,, 2008). A vizuális észlelés és gondolkodás kutatásában az emlékezet és a figyelem kitüntetett szereppel bír (Bartlett, 1932/1985; Duchowsky, 2007; Baddeley, 2001)

Az emberi gondolkodásban a vizuális dimenziót megelőzi a motorikus dimenzió, azaz izomfeszültségek, kinesztetikus élmények, mozgásunk (Bruner, 1966). Az 1980-as évek óta a fogalmi metaforaelmélet (Lakoff és Johnson, 1980) szerint a kinesztetikus érzékelések képi sémák kialakulásához vezetnek. A tudattalan mmotorikus élmények közül a szemmozgásoknak fontos szerepük van. Chafe (1980) párhuzamot mutatott ki a látás és különösen a szemmozgás és a verbális folyamatok között. Bizonyítást nyert, hogy a szemmozgások mintázatai és a gondolkodás mintázatai egymást tükrözik (Holšánová, 2008). A vizuális gondolkodást igénylő komplexebb problémák megoldásában szerepet játszik a motorikus komponens (Gombrich, 1959/1972).

\subsection{A vizuális észlelés}

Az észlelés az emberi megértés előfeltétele (Martindale, Moore és Anderson, 2005). Az első látásra egyszerünek tünő észlelés bonyolult komputációs folyamat, egyszerre biológiai és szimbolikus tevékenység. A vizuális észlelés a látáson alapul, mely nem passzív folyamat, nem hasonlítható a fényképezőgéppel történő képrögzítéshez. Az észlelés aktív folyamat (Sekuler és Blake, 2000). A vizuális észleléssel foglalkozó leírások kapcsán több nézet fejlödött a 20. század közepétől: Von Helmholtz, William James, Gibson, Broadbent, Anne Treisman, Kosslyn (Duchowsky, 2007). A látás során a figyelem vezérlése, hipotézisalkotás és ellenőrzés is történik. A hierarchikus befogadáselmélet szerint az észlelés információfeldolgozást jelent elsősorban. Az észlelés és a gondolkodás szorosan összefügg egymással, és összetett utakon megy végbe:

„a) ugyanakkor észleletek az agy megfelelö területének ingerlésével is kiválthatók;

b) agyi folyamatait illetően hasonlóság van az észlelet és a képzelet között;

c) a tudás és a kontextus erösen hat az észlelésre;

d) az észlelet nem az agy egy konkrét helyén születik meg, mivel az ingerület az agy különböző pályáin kerül feldolgozásra, miközben kapcsolatba kerül más észleletekkel és agyi tevékenységekkel" (Sekuler és Blake, 2000, 549. o.).

A vizuális fogalmak az agyban tárolt, látványhoz kapcsolhat ismeretek, melyek gyermekkortól bővülnek, tanulással és a környezeti tapasztalással formálódnak. Az alak és tárgylátás bonyolult folyamat, többféle módon megközelíthetjük. Látásunk saját élettörténetünk következménye és formálója egyszerre, hiszen az ember részt vesz saját környezetének alakításában azzal, ahogy értelmezi. A látás mellett értelmezi a kontextust, képzettársításokat végez, kiegészít, korábbi tapasztalataiba illeszti, hasonlóságokat és különbségeket észlel.

A reprezentációs látáselmélet (Marr, 1978) szerint a világról való gondolkodásunkban képeket és hozzájuk kapcsolódó analógiákat használunk, így a tudás egy belső térképhez hasonlítható. Az első pszichofizikai modell a látott kép tárgyakká szerveződéséről a Gestaltelmélet volt. A Gestalt megközelítés azt hangsúlyozza, hogy a tárgy több, mint részek összessége. A Gestalt-pszichológusok három területre fókuszáltak: az alakzat és a háttér összefüggései, a csoportosítás szabályai, az alakzatok permanenciája. A Gestalt-elméletek leírják azokat a fő szabályokat, amelyek alapján a háttértől már elkülönült körvonaldarabok egységes alakzatokká, tárgyakká szerveződnek. A Gestalt-pszichológia egyes megközelítései ma is érvényesek (Boring, 1942; Rock és Palmer, 1990). Az értelmetlen körvonaldarabkákat a Gestalt-törvényeknek megfelelöen csoportosítjuk. 
A strukturális felismerési modellek elmélete szerint a látás a retinára vetülő képpel kezdődik., a jelek feldolgozása az emberi látórendszer esetében már a szemben kezdődik. A retina neutrális rétegei képesek speciális képi tulajdonságok észlelésére. Ez a képfeldolgozás első szintje. Ebben a durva első vázlatképben körvonalak és olyan zárt alakzatok, mint kör, ellipszis is megtalálhatóak. Ebből alakul ki a Gestallt-törvények alapján a háromdimenziós kép, ez a képfeldolgozás középső szintje. A legmagasabb képfeldolgozási szinten történik az információk feldolgozása (Czúni és Tanács, 2011)

A látást, mint gondolkodási folyamatot leíró elméletek egy része egyetért a propozicionális struktúrával, mely szerint a tudásunk kijelentések formájában van jelen a gondolkodásban. Az agyban tehát kijelentés-sorozatok tárolódnak és keletkeznek. Mások (Kosslyn) a vizuális percepciót elkülönítik a nyelvi kifejezéstöl. Eszerint a vizuális kép nyelvi áttétel nélkül, a külső képpel izomorf mentális kép alakul a látás során. A mentális kép összetevői hasonlóak a valóságosan érzékelthez: forma, mozgás, szín információk mind megtalálhatók benne. Fontos szerepe van az asszociációk kialakulásában, fogalmak és jeleik, például a tárgy és betüképe azonosításában. A mentális kép nem fényképszerü. (Pléh, 2003; Schuster, 2005).

A kettős kódolás elmélete felől közelítve, mind vizuális, mind verbális valóság megismerési és leírási forma, kód létezik és müködik (Searle, 2003).

\subsection{A vizuális képességrendszer}

A vizuális alkotó és befogadó képességek halmaza alkotja a vizuális képességrendszert. Mivel kutatásunk tárgya a vizuális képességrendszer egy részét involválja csak, az alábbiaknak nem tekintjük át valamennyi komponensének kialakulását és fejlődését. A fejlődési modellek bemutatása után néhány, a képi közlés szempontjából különösen releváns képességelemeket veszünk számba.

\subsubsection{A vizuális képességrendszer fejlődési modelljei}

Kifejezetten a vizuális képességek fejlődésének kutatása a pszichológiai szempontokra főkuszáló vizsgálatokkal kezdődött. A képi ábrázolás fejlődését másfél évszázada több tanulmányban írták le (Kerschensteiner, 1905; Rouma, 1908; Luquet, 1927; Löwenfeld, 1947; Kellog, 1967). Az egyes rajzfejlődési szakaszokat különböző életévekhez kapcsolják a kutatók, de abban mindegyik szerző egyetért, hogy a gyermekkori rajzolás a vizuális képességek fejlesztésén kívül hatékony szerepet játszik az általános értelmi képességek fejlődésében. A képi gondolkodás fejlesztése tehát fontos része a kognitív gondolkodás fejlesztésének. Kepes (1979) szerint a képi gondolkodás strukturálja és alakítja a külvilágból érkező jeleket értelmes dolgokká (Kepes, 1979). Arnheim, (1974/1979) hangsúlyozza az érzékelés és az absztrakt gondolkodás egységét. Szerinte a gondolati műveletek nemcsak szavakkal és számokkal történő müveletekből állnak, hanem szerves részt alkot benne a képi gondolkodás is. Piaget kutatásai szerint a gondolkodás fejlődése egyszerre több területen jelenik meg: beszédkészség, zenei hallás és kifejezés, alak, forma és térlátási készségek, rajzi ábrázolás készsége, szimbolikus közlés készsége, stb. (Piaget, 1966/1999, 1978).

A vizuális képességek fejlődésének leírásának egyik megközelítése a lélektani és mentális jelenségeket, fizikai fejlődési sajátosságokat kutató ág (például Gerő, 1973/2007, 1981, 1983a, b; Feuer, 2000; Hárdi, 2002; Vass, 2006). A másik kutatási irány az alkotóibefogadói képességrendszer egészének fejlődését nyomon követő, pedagógiai célú értékelés (például Székácsné, 1982; Kárpáti, 1991, 1996, 2001, 2005). A következőkben azokat a rajzfejlődési elméleteket és modelleket foglaljuk össze röviden, amelyek keretét képezik a vizuális kommunikációval kapcsolatos kutatásainknak.

Gesell már 1925-ben regisztrálta a fejlődés szekvenciáit geometriai formák másolásának képességében: 2-3. év: horizontális vonal; 3-4. év: négyszög; 5-6. év: háromszög; 7-9 év: 
csúcsán álló négyszög, felosztott téglalap. A rajzolt emberalak színvonalából kb. 10 éves korig következtetéseket lehet levonni a rajzoló intellektuális szintjére.

Erre a gondolatra épül 1926-ban Goodenough által kidolgozott emberrajz-teszt. Goodenough tesztröl széles körü viták folytak, de egyetértés van abban, hogy bizonyos keretek között mégis informatív lehet, mert a gyerekek a „Rajzolj egy embert!” instrukcióra elsősorban intellektuális erőiket mobilizálják.

Piaget szerint a gyerekek rajzolásának fejlődése szakaszos. A szakaszok egymást követésével a gyerek a rajzolt tárgy egyre több vonatkozását ábrázolja (Piaget, 1966/1999, 1978). A modularista megismerés elmélet képviselöinek álláspontja (Fodor, 1983) szerint (Csépe, Györi, Ragó, 2008; Cole és mtsai. 2006), habár a rajzolási képesség normális fejlödéskor különböző szakaszokon megy keresztül, néhány lényeges kivétel azt sugallja, hogy a rajzolás különálló kognitív terület. Selfe (1983) több olyan gyerekeket is talált, akiknek a nyelvi képessége és az általános értelmi szintje alacsony volt, viszont a grafikus ábrázolásban kivételes képességet mutattak. Mindez annak a bizonyítéka, hogy az olyan mentális modulok, mint a nyelv és az észlelés egymástól viszonylagos függetlenségben fejlődhetnek. Gardner (1996, 1983) olyan gyerekekről számolt be, akiktől kisgyermekkorukban megvonták a rajzolás lehetőségét, és amikor megint rajzolhattak, akkor átugrották a kezdeti szakaszokat. Ezek a példák ellentmondanak a piaget-i álláspontnak. A kulturális megközelítés szerint, a rajzolás képességeinek fejlödése kontextus függő. A különböző nézőpontok alapján, különböző modellek születtek, melyek a gyermekrajzok fejlődését meghatározó három alapvető tényezőjének valamelyikét állítják fókuszba:

1. biológiai adottságaink,

2. az adott nemzet kultúrájának sajátosságai (müvészeti élet, nevelés, gyakorlás mértéke, felnőttek visszajelzései, életmód),

3. a gyermek egyéni jellemzői: ízlése és vizuális alkotó és befogadó képességeinek szintje, mely meghatározza képalkotó stílusát (Kárpáti, 2001, 2004)

A modellek különbözőképpen írják le a vizuális képességek fejlődését. A müvészetpedagógiában ma leggyakrabban hivatkozott modellek: a lineáris, a spirális és a poliszenzorális modell. A modellek különbségei a pedagógiai szemléletmód sajátosságaiból adódnak, a képességfejlődés leírása mindig a fejlesztés kívánatos módjainak meghatározásával zárul.

A lineáris fejlödési modell (Nagy, 1905, Goodenough 1926, Read, 1944; Arnheim, 1974/1979) szerint a vizuális ábrázolás fejlődése folyamatos technikai tökélesedést jelent, tehát a gyermekek az alaktalan firkák vonalhálóitól fokozatosan jutnak el az élethü ábrázolásig. A modell szerint 4-6 fejlődési korszak létezik. A rajzolás lényege a leképezés, azt és annyit rajzol a gyermek, amit és amennyit az ábrázolt tárgyról tud. Az elmélet szerint az egyes fejlettségi szinteket jelző szakaszok szorosan összefüggnek az értelmi fejlődéssel, a szakaszok életkorhoz kötöttek. A lineáris modellt többen cáfolták (pl. Golomb, 1974; Freeman, 1977), akik szerint a fejlödés sosem folyamatos. A gyorsan tanuló gyermekeket például diktálással, arányok pontosításával gyorsan meg lehet tanítani a bonyolultabb ábrázolási konvenciókra, így több spontán érési szintet is átugorhat a gyermek, akár egyetlen nap alatt. Ugyanakkor a rajzfejlődésre az érdeklődés is jelentős hatást gyakorol, így különböző technikákban is mutatkozhat a begyakorlásból adódó különbség. A biológiai állapot sem elhanyagolható tényező az aktuálisan mutatott rajzi szintnél (például. éhség, fáradtság) és a motiváció hiánya is megnyilvánulhat hanyag, korábbi fejlettségi szintet mutató ábrázolásban. A modell a 19. század végének romantikus és realista stílusát előnyben részesítő művészeti ízlésen és a képzőművészeti akadémiák valósághű ábrázolásra törekvő oktatási gyakorlatán alapul. Ez a szemlélet kevesebb hangsúllyal, de napjainkban is jelen van a vizuális nevelésben, ezért a modell ma is megjelenik a rajzpedagógiai szakirodalomban. Mivel a vizuális kommunikációs képességet, mint kifejező, közlö, információt befogadó és 
feldolgozó képességet értelmezzük, a lineáris modell, amely az ábrázolási konvenciókon alapuló, pontos leképezést tekinti optimális teljesítménynek, kevésbé használható a képesség fejlődésének leírásához.

A rajzi képességek spirális modelljében (Löwenfeld, 1970; Goodnow, 1977, Golomb, 1974, Kellogg, 1977) központi szerepet kap a kifejezés, a belső tartalmak ábrázolása. A vizuális ábrázolás és a személyiség szorosan összefügg, a rajz a lelki állapotokat tükrözi, ezért használják müvészek és laikusok egyaránt a verbális közlésben fel nem tárható problémák megjelenítésére. A spirális modell szerint elemzők a médiumoknak vizuális képességekre gyakorolt hatását is vizsgálják, és fontos belátásokra jutottak a digitális képalkotás sajátosságairól. A egyes médiumokon a fejlödési korszakok ugyanazok, de a fejlödés üteme eltérö. Ennek oka, hogy az eltérő anyagok, technikák, különböző képalkotó programot hívnak elö. Máshogy épül fel például egy síkbeli alkotás vagy egy térbeli, a színek, formák, méretek meghatározzák a képalkotást (Freedman és mtsai, 2013).

Napjainkban meghatározó szerepet töltenek be a digitális médiumok, hiszen az alkotást egyre kevésbé határozza meg a rajzolástechnikai tudás. A közösségi oldalak számos lehetőséget kínálnak a képi önkifejezésre (profilképek, élményeket, hangulatokat bemutató képsorozatok, szöveggel és a kép átalakításával újraértelmezett fotók és müalkotások) (Kárpáti, 2011; Császár, 2016). A kutatásunkban szereplő elektronikus tesztelő felület szintén hatással van a gyermekek képalkotó és befogadó képességére. Az értékelést ugyan nem befolyásolja, mert minden gyermek ugyanazon a médiumon oldja meg a feladatokat, de a médium hatását mindenképpen vizsgálnunk kell. A vizuális nevelésben még ritka a digitális értékelés alkalmazása, eredményeinket pedig más médiumon történő adatokkal is szeretnénk összevetni eredményeinket.

A spirális modell egyik elágazása a fejlődési tendenciákat is bemutató $U$ alakú görbe (U-shaped curve, Gardner, 1996). Az U bal oldali kiindulópontja és lefelé ívelő szára a kisgyermek kiváló teljesítménye az óvodai és iskolai képzés hatására bekövetkező romlását mutatja be. A mélypont, az U alsó szakasza a 10-12 éves kor, itt van vége a spontán, örömteli ábrázolás korszakának. A jobb oldali, felfelé ívelő ágba csak azok a tehetséges gyermekek jutnak el, akik képesek az iskolai nevelés káros hatásait leküzdeni. A modell képviselöi szerint tehát a tanítás általánosan követett módja káros. Bár egyoldalúan kritikus ez a modell, de ráirányítja a figyelmet az iskolai oktatás hatására. A modell nem alkalmas a képességek leírására multikulturális környezetben (Haanstra, Damen és Hoorn, 2011).

A spirális modell kitünően alkalmazható a vizuális kommunikációs képességek leírására, hiszen a kifejezést állítja középpontba, és a környezeti és társadalmi tényezőket valamint az alkotás műfajt és médiumát is figyelembe veszi. A modell szerint dolgozó kutató és pedagógus mindig figyeli az iskolai oktatás hatására, és fejlesztési projektekkel segít átlendülni a spirál megrekedő vagy visszafejlődő szakaszain.

A poliszenzoriális modell (Kindler és Darras, 1997) lényege a rajzolás, a beszéd és a gesztusnyelv közti kapcsolat megtartása, feltárása, több médium együttes használata. Ezáltal a modell követi számos, a 21. század első évtizedeire különösen jellemző képzőművészeti irány multimediális alkotásmódját. A modell a rajzok mellett a gyermekek más vizuális produktumait (plasztikák, asszamblázsok, kollázsok, tárgyak, építmények, multimédiás produktumok) is figyelembe veszi és összekapcsolja a vizuális képességrendszer fejlődését a társmüvészetekben mutatott fejlődéssel. Minden technikának ugyanolyan értékes szimbólumalkotó szerepe van, és tágítja a képi kifejezés határait.

Ez a modell is igen fontos kutatásunk szempontjából. Integratív szemlélete megfelel a 21. századi elvárásoknak és a vizuális kommunikáció komplexitásának. Vizsgálatainkban a modalitásváltás és a szimbólumalkotás és értelmezés képességelemeinek vizsgálatára alkalmaztunk poliszenzoriális teszteket. 


\subsubsection{A vizuális kommunikációs képesség helye a vizuális képességek rendszerében}

A következőkben ismertetjük a vizuális kommunikációs képesség helyét a vizuális képességek rendszerében.

A vizuális képességrendszer két nagy alrendszerből áll: a vizuális alkotás és befogadás rendszereiből. A vizuális befogadás a látható világ érzékelése és észlelése. Az érzékelés a látvány tudomásul vétel, az észlelés a látvány kapcsolása személyekhez, dolgokhoz, fogalmakhoz, hangulatokhoz. A vizuális befogadás segítségével a látványban tanult képzeteink segítségével felismerjük a világ jelenségeit. Az ember vizuális befogadó tevékenysége kiterjed a teljes látható világ befogadására a hétköznapi tárgyaktól a természeti képeken át a müalkotásokig illetve a vizuálisan észlelés nem közvetlenül szem ingerfelvevő funkciójában történő területére is (Panofsky, 1955/1984; Antik, 2010). A vizuális alkotó tevékenység minden látható, ember által készített tárgy, kép megvalósítására irányuló tevékenység. Az alkotás független tárgyától és anyagától, illetve akár szellemi dimenzionáltsága is lehet (konceptualista törekvések ${ }^{8}$ ).

Az alkotás és a befogadás kérdéseivel számos tudományterület foglalkozik, mint például a kognitív pszichológia, a müvészetpszichológia és a müvészetelmélet. A mübefogadásról bőséges a szakirodalom (Martindale, Anderson, Moore, 2005; Panofsky 1955/1984; Bätschmann, 1998a; Goodman, 1977; Farkas és Gyebnár, 1995), de a tágabban értelmezett vizuális befogadásról kevesebb kutatás (Illés, 2000, 2008) történt.

Mint ahogy a mübefogadás a vizuális befogadásnak csak egy aspektusát jelenti, úgy az alkotó tevékenység sem csak művészi vagy tudományos alkotómunkát jelent. „A vizuális alkotás valamely személyes és/vagy közös célok elérésére vonatkozó olyan problémamegoldó gondolkodás eredményeképpen jön létre, amely gondolkodásban ismeretszerzés történik. Az alkotás, mint jelenvalóság felől közelítve: a vizuális alkotás személyes és közös célokat szolgáló probléma/problémák megoldása és ismeretek tárolása/örzése" (Sándor, 2011. 82.o..).

A vizuális nevelésben, az 1990-s években, a gyermekrajz fejlödési vizsgálatokkal párhuzamosan elindultak a müelemzés- és müvészettörténet tanitási kutatások is (Kárpáti, 1985, 1993). Ezek eredményeként részletesen leírt képességstruktúra és empirikus kutatásokkal feltárt fejlődési szakaszok segítették a tantervírók munkáját. A Nemzeti Alaptanterv ${ }^{9}$ valamennyi fogalmazványában elkülönülnek a vizuális alkotás és befogadás képességelemei és ezek fejlesztésére javasolt módszerek és tartalmak. említjük:

A befogadás (percepció) leírásakor az iskolai oktatásban fejlesztett részképességeket

- a látásos érzékelés, mint szenzomotoros folyamat,

- a forma és formai különbségek azonosítása,

- a képi jelek és a szövegek együttes értelmezése: ábraolvasás, dinamikus vizualizációk értelmezése, illusztráció és mü együttes átélése stb.

- színlátás

- térértelmezés

- müalkotások értelmezése és elemzése

A mủalkotások értelmezése és elemzése a vizuális befogadó képesség egy sajátos formája, amelyet az iskolai oktatásban központi szerepet kap. A vizuális kommunikációs képesség tevékenységeinek egy része a vizuális befogadás körébe tartozik: ilyenek a felismerés, értelmezés, elemzés (Kárpáti, 1992b).

\footnotetext{
8 A konceptualizmus a kortárs képzőművészet egyik irányzata, amely a gondolatot tartja elsődlegesnek a mű megvalósításában. A mủalkotást a rá vonatkozó ötlet, gondolat váltja fel, amiből leírás, kép, grafikon, video-és magnószalag marad. A müalkotáshoz tartozik a gondolat, amit a müalkotás kivált. A mondanivaló vizuális megjelenítése változatos formában jelenik meg (szöveg, hang, tárgy, például: Joseph Kosuth 1965: One and Three Chairs)

9 110/2012. (VI. 4.) Korm. rendelet a Nemzeti alaptanterv kiadásáról, bevezetéséről és alkalmazásáról https://ofi.hu/sites/default/files/attachments/mk_nat_20121.pdf
} 
A vizuális alkotó képességek csoportja a vizuális befogadó képességcsoport mellet a vizuális képességrendszer másik nagy alrendszere. Az iskolai oktatásban fejlesztett részképességei:

- térbeli alkotás és térábrázolás

- színhasználat, színkompozíció

- formaábrázolás

A vizuális kommunikációs képesség tevékenységei magukban foglalják a vizuális alkotás és befogadás alrendszereinek számos tevékenységét. Mivel a kommunikációs folyamatban mindkét alrendszer szerepet kap, rendszerezhetjük a nyelvi kommunikáció analógiájára a kódolás és dekódolás műveletei szerint is. (2. táblázat). Ily módon a képességeket két részre osztottuk: befogadó (dekódolás) és alkotó (kódolás) képességek.

2. táblázat A vizuális kommunikációs képesség rendezése a nyelvi kommunikáció analógiájára (Bálványos, Sánta, 1977. 99.o.ábrája alapján saját szerkesztés)

\begin{tabular}{|c|c|c|}
\hline \multicolumn{3}{|c|}{ vizuális kommunikáció } \\
\hline szintek & $\begin{array}{l}\text { emocionális-tapasztalati- } \\
\text { müveleti szint }\end{array}$ & $\begin{array}{l}\text { emocionális-racionális- } \\
\text { kreativitási szint }\end{array}$ \\
\hline befogadás & ábraolvasás képessége & ábraértelmezés képessége \\
\hline dekódolás & & \\
\hline közlés & ábrázolás-kifejezés, & ábraalkotás, műalkotás, \\
\hline kódolás & $\begin{array}{l}\text { formálás-kifejezés, } \\
\text { díszítés-kifejezés képessége }\end{array}$ & $\begin{array}{l}\text { tárgyalkotás, környezetalakítás } \\
\text { képessége }\end{array}$ \\
\hline
\end{tabular}

A kognitív kommunikatív képesség funkciója az információk közlése és értelmezése szimbólumok által. Ebben a kommunikációs folyamatban gondolkodunk is, tehát összefügg a tanulással. Nagy (1998) kognitív kompetencia rendszerében a tanulás, a kommunikáció, a gondolkodás és a tudásszerzés szerepel, mely utóbbinak része az ismeretszerző, problémamegoldó és az alkotóképesség. Ebben a kompetencia modellben a kognitív kommunikáció képességrendszerének része a vizuális kommunikáció. Nagy József szerint a vizuális kommunikációs képessége sokféle készség, ismeret által müködik. „Például: méretlátás (az ábrázolt dolgok reális méretének elképzelése), térlátás (síkban, vetületekkel ábrázolt dolgok képzeletbeli rekonstrukciója háromdimenziós alakká, térbeli viszonyokká), szerkezetlátás (dolgok szerkezetének képzeletbeli felépítése metszetek alapján), dinamikalátás (állapotváltozások, dolgok müködésének, viselkedésének elképzelése állókép alapján) és hasonlók; továbbá: a formaábrázolás, méretábrázolás, térábrázolás, szerkezetábrázolás, dinamikaábrázolás és hasonlók készségei, a velük kapcsolatos ismeretek.” (Nagy, 1998. 12.o.).

Stohner (2005) a vizuális alkotás kompetencia-alapú leírásához a vizuális nevelés szakirodalmában (Bálványos és Sántha, 1998; Bakos, Bálványos, Preisinger és Sándor, 2000, (Környeiné, 2001a, 2001b, 2002) publikációiban szereplő képesség leírások tartalomelemzését végezte el. A vizuális befogadást, mint a vizális képességrendszer két alrendszerének egyikét Vizuális Aktivitás Speciális Kompetenciának nevezte el, és a tartalomelemzéssel feltárt, mintegy 180 vizuális tevékenység leírása után, három részképesség csoportra osztotta:

1. Vizsgálódás, kísérletezés, képzetgyüjtés., Ide tartoznak a felismerés, azonosítás, tipizálás analógiaképzés részképességei is

2. Megfeleltetés, megformálás, megvalósítás. . Megfeleltetés, illetve megvalósítás alatt érti a szerző a verbális projekciót, azaz a gondolati szinten művelt belső vizualitást is. Ehhez a képességcsoporthoz a következő képességelemek tartoznak: beleélés, elemzés, értelmezés, létrehozás, konvertálás képessége. 
3. Információkezelés, üzenetközvetítés és fogadás komplex képessége, melynek lényege a kódok sajátosságainak feltárása, kulturális meghatározottságának megértése, a vizuális kommunikáció formáinak értelmezése, hagyományok és tradíciók értékelése. A képességcsoport elemei a tradíció-kezelés, a konvenciókezelés, a kódolás és a dekódolás képességei.

Ez a rendszer az itt bemutatott kutatás szempontjából azért érdekes, mert a szakirodalom elemzés alapján létrejött fogalmi struktúrában a három nagy fogalomcsoport egyike a vizuális kommunikációs képesség. A vizuális nevelésben tehát évtizedek óta kiemelkedő jelentőségünek tartják ezt a képességet, de tevékenységeinek kutatás alapú leírására csak a jelen értekezés vállalkozott.

A vizuális képességekrendszer tevékenységei és tudáselemei együtt alkotják a vizuális műveltséget (visual literacy). 2010-ben alakult az Európai Vizuális Műveltség Hálózat, amelynek jelenleg 21 ország mintegy 70 vizuális nevelési kutatója a tagja. A kutatói közösség első projektje volt a Közös Európai Vizuális Műveltség Referenciakeret (European Framework of Visual Literacy) kidolgozása (Wagner és Schönau, 2016, magyar összefoglaló: Kárpáti és Pataky, 2016). A modell tartalmazza a vizuális kompetencia összetevöit,19 tevékenységet emelve ki az alkotás és befogadás területeiről. A tevékenységek meghatározása itt is tantervelemzéssel történt, 23 európai tanterv értékelése volt az alap. A keretrendszer sajátossága, hog necsak tevélnségeket határoz meg, hanem a képi nyelvhasználat jellemzö helyzeteinek leírását (Situations) is tartalmazza (Billmayer, 2016). A szerzők a vizuális kompetencia müködésének meghatározó elemének tartja az (ön)reflexiót, empátiát, a jövő prognosztizálását és a kísérletezéstAz európai kutatási erdményeket és tantervi koncepciókat szintetizáló keretrendszer jelentősége, hogy túllép a vizuális nevelés szokásos felosztásán és a vizuális müveltséget az alapműveltség részeként írja le (3. ábra). Ebben a képességrendszerben a személyes kompetenciák (az érett személyiséget jellemző tudáselemek, képességek és attitüdök), a társas képességek, és a világ megismerésére alkalmas, alkotói és befogadói képességelemek egyaránt megtalálhatók. A keretrendszerben kiemelt szerepet kap a képi kommunikáció, melyet különböző társas helyzetekben írnak le és javasolnak fejleszteni (Billmayer, 2016). 


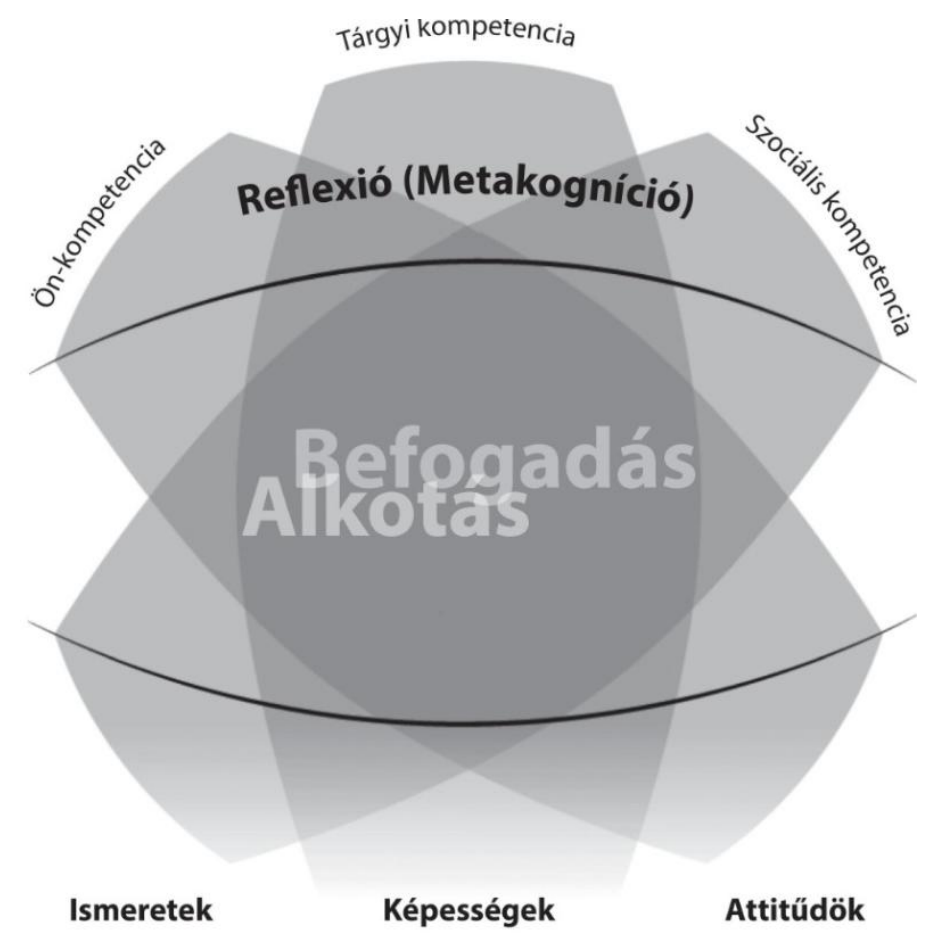

3. ábra: A vizuális müveltség összefüggései a személyes és társas kompetenciákkal. (Forrás: az Európai Vizuális Müveltség Hálózat (European Network of Visual Literacy) honlapja, http://envil.eu https://mersz.hu/hivatkozas/matud_f8110 A magyar nyelvü ábra forrása: Kárpáti-Pataky, 2016, 11..)

Az alkotás és befogadás képességcsoport tovább tagolható (4. ábra). Ebben a kontextusban kapott helyet a kommunikáció.

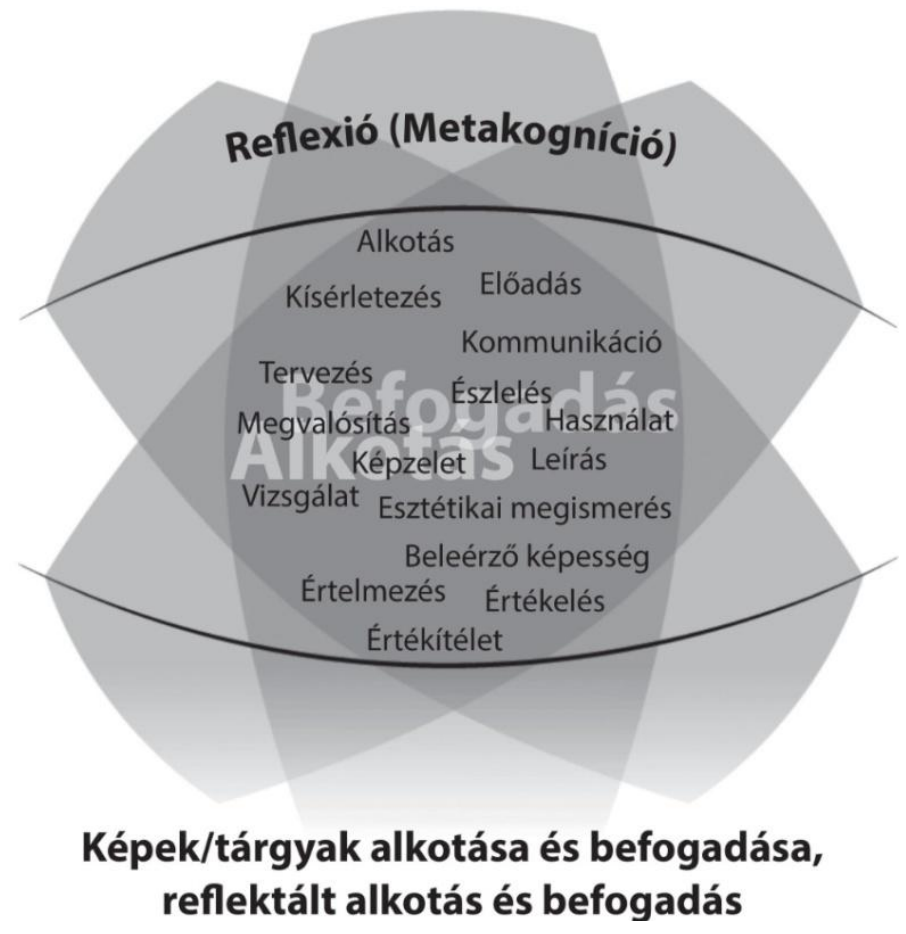

4. ábra A vizuális kompetencia befogadás ás alkotás összetevői az Európai Vizuális Müveltség Referenciakeretben (Forrás: az Európai Vizuális Müveltség Hálózat (European Network of Visual Literacy) honlapja, http://envil.eu https://mersz.hu/hivatkozas/matud_f8110 A magyar nyelvü ábra forrása: KárpátiPataky, 2016, 11.) 


\subsection{A 10-12 éves gyermekek képi közlésének sajátosságai}

Mivel a jelen kutatásban szereplő évfolyamok tanulóinak nagy része 10-12 éves korosztályba tartozik, ezért fontosnak tartjuk áttekinteni a korosztály képi közlésének jellemzőit, és a fejlődés ívét a 6-12 éves korosztályban, amely két rajzfejlődési korszakot a kisiskolások és a kiskamaszok ábrázolásmódját foglalja magában (Babály, Budai és Kárpáti, 2013, Kárpáti, 1981a, 1981b; Kárpáti és Pethö, 2012). A kisiskolás korban (6.-8. életév) „tündéri realiszmus”, szimbólumokban bővelkedö, érzelemgazdag, meseszerü, de nyomokban a tapasztalatokat is megjelenítő stílus jellemzi a gyermekrajzokat. A transzparencia - a takarásban lévő, nem látható részek megjelenítése - 7-8 éves korig jellemző, majd egyre csökken és 10 éves korra eltünik. Kiskamasz korban (11-14. életév) a érzelmi feszültsége csökken. A gyermeket egyre jobban a „reális” (a kortárs konvencióknak megfelelö) ábrázolásmód foglalkoztatja. A rajzokon csökkenek a saját szimbólumok, alakok és formák száma és szívesen másolnak. A megtanult technikák és sablonok kerülnek előtérbe. 9-10 éves korra megjelenik a perspektíva ábrázolása és rendeződnek az arányok a rajzokon. Finomodik a kézmozgás és fejlődik az analizáló, szintetizáló képesség. Ekkor kétféle rajzolói magatartást különböztethetünk meg: az egyik a szintetizáló, aki az egészet emeli ki a környezetből, egyegy érdekes részletet hangsúlyozva kontúrral, aprólékos megjelenítéssel. A másik az analizáló, akit a szerkezet, a felépítés foglalkoztat. Ebben a korszakban jelenik meg a jelalkotás, a funkcionális ábra, térkép, alaprajz, amelyen kommunikációs célú sematizálás figyelhető meg. A képekkel való gyakori találkozás hatására jelentősen megnő az egyéni motívumkészlet és gazdagodik a kompozíciós repertoár.

Gerő (1973/227, 1981) szerint a kisiskolások (5-8 évesek) esztétikus és kifejező rajzaival szembeállíthatók a korai kamaszkorban készült alkotások, melyek szétesettek, sematikusak, zavarosak. Az okot a gondolkodás és az élményfeldolgozás különbözöségében látja. Szerinte a grafikus készség nem romlik, sőt, határozott fejlődést mutat ebben a korban is, de a téma feldolgozása apró résztárgyakra esik szét. A 2000-es évek kutatásai alapján megállapítható, hogy nincs teljesítményromlás, ellenkezőleg, számos lényeges képességelem javul, ha megfelelő témát és médiumot kapnak a gyerekek (Gaul és Kárpáti, 1998, Séra, Gulyás és Kárpáti, 2002, Kárpáti, 2002, 2005). A 9-12 éves kori szakaszban bekövetkezö, „rajzi törés”-nek nevezett teljesítményromlás valójában nyelvváltás, amely során a hagyományos képi ábrázolás - például az emberrajz és térmegjelentés - is tovább fejlődnek (Kárpáti, 2005). A gyermek úgy akarja megjeleníteni a dolgokat, ahogy látja, mely igénynek nehéz megfelelni. A hagyományos eszközökkel való rajzolás háttérbe szorul, de fotói, filmjei, környezetének alakítása, saját készítésủ tárgyai vagy viselete jelzik, hogyan fejlődik tovább a képi kifejezésben.

Ez a korszak a plasztikai és formatervező képességek virágkora. A kortársak nagy hatása figyelhető meg, megnő a realista ábrázolás, az emberrajz kifejezi az életkort, a nemet, a hangulatot, a kulturális környezetet. Ebben a szakaszban sajátítják el a gyerekek a tér-és színábrázolási konvenciókat is (Babály, Budai és Kárpáti, 2013). Ezek a sajátosságok meghatározzák a pedagógiai kereteket, módszereket, mert nem mindegy, melyik szakaszban milyen eszközt és témát adjunk a gyerekeknek. Az érzelemben gazdag, életből vett témák nagyobb motivációt jelentenek, továbbá megnő a társas kapcsolatok jelentősége, és ebböl következően a csoportmunka szerepe.

A digitális eszközök széles körü elterjedése elött a 10-12 évesekre jellemző volt a vizuális nyelv háttérbe szorulása a verbálissal szemben. A könnyen hozzáférhető, inspiráló, rugalmas képalkotó technikák bővülésével, az egyre könnyebb hozzáféréssel és a digitális énmegjelenítési platformok bövülésével a korosztály képalkotó kedve nem csökken, sőt, a képekkel történő énkifejező tevékenység és kommunikáció folyamatosan nő. A vizuális nyelv a közlés természetes módja, s ennek megértéséhez a klasszikus művészeti értékek helyett a 
kortárs alkotók stílusirányzatai és közlésmódjai segítenek (Freedman és mtsai. 2013; Kárpáti és mtsai., 2016; Gaul szerk., 2015).

Napjainkban a vizuális képességeken belül a vizuális kommunikációs képesség jelentősége nő, mivel a korosztályra jellemző a digitális technika széleskörü elterjedése és alkalmazása, valamint a technika által lehetővé vált képalkotás, képmanipuláció és képmegosztás a mindennapi társas, kommunikációs gyakorlatban. A vizuális képességek fejlesztése a nevelés történetében változó hangsúllyal és tartalommal szerepelt, napjainkban éppen a vizuális kommunikáció társadalmi szerepe miatt felértékelődik ez a terület. A következőkben áttekintjük, milyen szerepet vállaltak az oktatási intézmények a vizuális képességek fejlesztésében, különös tekintettel a vizuális kommunikációs képesség fejlesztésére. Azt is megvizsgáljuk, milyen tartalmakkal és módszerekkel szerepel a hatályban lévő Alaptantervben és néhány kerettantervben. 


\section{A vizuális kommunikáció helye és szerepe a pedagógiai gyakorlatban}

\subsection{A vizuális kommunikáció a vizuális nevelés történetében}

A vizuális kommunikáció kifejezés néhány évtizedes múltra tekint vissza, de a vizuális kommunikáció elemei koronként más hangsúllyal és tartalommal, felfedezhetőek a vizuális nevelés történetében. Napjaink képekre épülő kultúrájában megérett a helyzet a vizuális kommunikáció rajz és vizuális kultúra oktatási és nevelési folyamatokban betöltött szerepének kiemelésére, a tankönyvek, oktatási segédletek áttekintésére.

A vizuális művészeti nevelés mindig szoros kapcsolatban állt az adott kor vallási, filozófiai, társadalmi rendszerével és művészetfelfogásával. A képzőművészet viszonylag későn jelenik meg az iskolai tantervekben, annak ellenére, hogy már az ókori Görögországban megszületett a vizuális tapasztaláshoz kapcsolódó müvészi szemlélet. A 15. században a nyomtatás terjedésével a képben rögzített ismeretek széles körű terjesztésének lehetősége nyílt meg. Albrecht Dürer a geometria alapkérdéseivel foglalkozott (síkgörbék szerkesztése, szabályos sokszögek szerkesztése, térbeli alakzatok - gúlák, hasábok, hengerek - ábrázolása, testek árnyékainak megszerkesztése). Az általa alkalmazott képi kommunikációs rendszer három évszázadon keresztül meghatározták a geometrikus ábrázolási módokat. A 16. században jelent meg az első európai festőmintakönyv, melyet több száz, a képi megjelenítés szabályait gyakorlatokkal tanító traktátus követett. Ezek leghíresebbje Leonardo da Vinci Trattato della Pittura, melyet Raffaelo du Fresne állított össze a mester kézirataiból 1651-ben (magyar nyelven: A festészetről, 2005). Az írásokból nemcsak az derül ki, hogyan valósíthatók meg a reneszánsz festészet jellegzetes stílusjegyei (például a lineáris perspektíva, a chiaroscuro árnyalási módszer, az emberi test méretarányos megjelenítése) hanem a műalkotások megítéléséről és a festők helyes életmódjáról is hasznos tanácsokat ad. Agostino Caracci pedagógiai magánakadémiáján a 17. század második felében Leonardo pedagógiai elképzeléseit elevenítették fel a festő-tudós (pictor doctus) neveléséről, benne a rajzolásról, mint tudományos megismerő tevékenységről és megjelent az akadémiai alakrajz.

A 18-19. század képzőművészetét meghatározó akadémiáknak szigorúan felépített tanmenete volt, mely szerint a tanulás gipszöntvényeken bemutatott görög, római és reneszánsz plasztikák és örökérvényünek vélt reneszánsz és barokk festmény részleteket tartalmazó mintakönyvek metszeteinek másolásával kezdődött. Ezek a mintakönyvek voltak tulajdonképpen az első vizuális szótárak, melyeknek használatával vált egységesebbé az európai képi nyelv. A 17. századi jezsuita kolostoriskolákban a szépírás, a zene, és a geometria tanítása mellett, rajzra és építészetre oktatták rendjük ügyes kezü tagjait. Az akadémiai hagyományok a 18. században megrendülnek, és a 19. században elkezdődött az a változás, ami a 20. század dilemmáit előrevetítette (Bodóczky, 2003; Csőregh, 1991).

Az esztétikai-müvészetpedagógia kezdő mérföldköve John Ruskin: A rajz alapelemei (Elements of Drawing) címü könyvének megjelenése volt 1857-ben. A gyermek és a müvészet kapcsolatáról szólt 1887-ben Corrado Ricci, és 1888-ban Bernard Perez müve is, majd öket követi James Sully, modern gondolkodást tükröző müve (Tanulmányok a gyerekkorból) és Julius Langbehn: Rembrandt, a nevelö címü korszakalkotó könyve. A 19. században kezdődtek meg Európában a törekvések a rajztanítás kötelezővé tételére, de az alapfokú iskolákban csak a század végére lesz kötelező tárgy. A tananyag a müszaki rajz elemeiből és a klasszikus mủvészeti stílusok díszítményeinek másolásából épült fel. William Minifie az írás elsajátításához tartja fontosnak a rajzolást és Pestalozzira hivatkozik, ahogy Anglia, Franciaország és Hollandia pedagógusai is. John Dewey a rajzoktatás céljának a személyiség kibontakozását tartja. A szabadkézi rajz, mint a látásfejlesztés módszerét alkalmazta Flinzer és a naturalista pedagógiai iskola (Kárpáti, 1995a).

A 19. század utolsó évtizedétől a gyermeki individuum önállóságáért és szabadságáért való törekvések törtek utat. A „New School” programját több európai iskola tette magáévá. Nagy szerepe volt a korszak pedagógiájának megújításában Adolf Ferriere-nek (svájci), 
Maria Montessorinak (olasz) és Ovide Decroly-nak (belga). Montessori a vizuális nevelés feladataiban az észlelést, érzékelést fejlesztő eszközökre helyezte a hangsúlyt. Ezek az eszközök a mindennapi életben való eligazodást segítették, s mint ilyenek, kommunikációs feladatokat is ellátnak. A gyerekek napirendjében benne volt a kézimunka, a festés, a rajzolás és a mintázás (Kárpáti, 1997a; Bábosik, 1997).

A korszak végének nagy hatású pedagógusai Karácsony, Freinet és Steiner (Trencsényi 1999, 2005). Freinet forradalmian új iskolai esztétikai nevelést gyakorolt. A napi ihletet adó sétákat követően felolvastak, közben rajzoltak és jegyzeteltek a diákok. A szabad alkotás és a különféle grafikai eljárások együttes gyakorlása után az elkészült rajzokat meg is beszélték, illetve naponta kiválasztva kettőt betettek az „Élet könyvébe” (Kárpáti, 1997a). Ez a feladatsor szép példája, hogyan illeszkedett az esztétikai nevelés tárgyba a még fogalmilag nem létező vizuális kommunikáció. A két világháború közötti időszakban jelentős iskolakoncepciók alakultak, melyek közül a Steiner nevével fémjelzett Waldorf-pedagógia egyértelműen művészeti neveléssel átitatott (Steiner, 1992). A Waldorf-módszer alkalmazása során a gyerekek készítik el saját rajzos tankönyveiket, így alkotások informatív szerepe is előtérbe kerül, mely által erőteljesen kapcsolódik a vizuális kommunikáció tartalmaihoz.

A 20. században az alkotó, kreatív ember középpontba kerülésével sorban jelentek meg a reformpedagógiák. Nagy László (Nagy, 1905) 1905-ben megjelent „Fejezetek a gyermekrajzok lélektanából" című könyvében a gyermekek képességeiről ír, melynek hatására az akadémiai rajztanítás elemei háttérbe szorulnak, és megindult e gyermekrajzok gyüjtése, rendszerezése (Kárpáti, 1997a; Bornstein, 1984/1997). A hatvanas évektől a 20. században egymásra torlódó művészeti áramlatok nem jutottak el az iskoláig. A klasszikus és kortárs művészeti kultúra szétválasztása a 19. századi romantika és realizmus irányzatait oéldaként, a 20. századelő „izmusait” eltévelyedésként beállító szovjet müvészetpedagógia szemléletmódja a nyolcvanas évekig nyomot hagyott a vizuális kultúra oktatásában. Ennek ellenére az 1960-as évektől élt az alternatív müvészetpedagógiai kultúra, a képi nelvet, és nem ábrázolási konvenciókat tanító szemléletmód. Bak Imre és Lantos Ferenc munkássága különösen nagy hatással volt arra, hogy a „rajz” tantárgy átalakuljon vizuális neveléssé, és a tantárgyba bekerültek a vizuális nyelv, vizuális kommunikáció, a tárgy-és környezetkultúra és mára a médianevelés elemei is. (Kárpáti, 1988).

Az 1970-es évek általános iskolai neveléséből hiányzó komplex szemlélet hiányát pótolta az akkor induló, ma is működő GYIK Mühely, ahol a vizuális tevékenységekhez már kezdettől fogva társult a zene, a mozgás, a film és később a videó is. Nem „csak” a kreativ készségek kibontakozását tüzték ki célul, hanem azon keresztül a psziché kommunikációját. E szimbolikus beszéd legáltalánosabb megnyilvánulása a vizuális nyelv, melynek gyakorlati használatához a képzőmüvészet eszközrendszerét használják (Hegedüs, Kalmár, Szabics 1997; Eplényi, 2006). A müvészeti nevelés szerepeinek változásával összemosódtak a határok a müvészeti nevelés és a müvészeteken keresztül való nevelés között. A különbségtétel fontosságára hívja fel a figyelmet az UNESCO megbízásából végzett, mintegy 50 ország müvészetpedagógiáját áttekintő kutatási jelentésében Anne Bamford (2006). Szerinte a képi kommunikáció megtanítása éppen olyan fontos, mint a müalkotások befogadására nevelés és a kreatív alkotás. A vizuális nyelv elsajátítása jó hatással lehet szinte valamennyi iskolai tantárgyban nyújtott teljesítményre. A müvészeti nevelés tartalmazza a vizuális nevelést, a müvészet általi nevelés pedig felhasználja más tartalmak továbbadására az előbbiben megszerzett tudást (Bamford, 2006; Bodóczky, 2009).

A vizuális nevelést nem szabályozták rendeletekkel minden korszakban, irányt mutató tankönyvek is csak 18. században jelentek meg. Az 1783-ban, Bécsben kiadott királyi rendelet elöírta a vasárnapi rajziskolák felállítását az inasok számára, valamint a müszaki pályára készülő elemi iskola negyedik évfolyamos tanulói számára is kötelezővé tette a rajztanítást. Ez a rendelet tekinthető a rajzoktatás első tantervének, „vezérkönyvének”, mely 
szabályozta a rajzoktatás tartalmát és az alkalmazandó oktatási módszereket is. Nagy általánosítással kijelenthető, hogy a 20 . század végéig a rajzolás és festés, kisebb mértékben a plasztika, tehát a képzőmüvészeti jellegü alkotás állt a rajztanítás középpontjában (Kárpáti, 1997a).

A hazánkban Mária Terézia által kibocsátott Ratio Educationis az első olyan rendelkezés, királyi rendelet, amely kísérletet tett a magyar oktatásügy állami rendezésére, s mely a továbbtanulni nem szándékozó tanulók számára olyan készségek oktatására is hangsúlyt fektet, mint például a szabadkézi rajz, amelynek ismerete hasznos lehet a különböző mesterségek tanulása során. A 18. században jelennek meg az első Sárvári Pál nevéhez kötődö, magyar nyelvü rajztankönyvek. Vizuális nevelésen az aktuálisnak vélt szellemi értékeknek az elsajátítását és interpretálását tartották, egyet jelentett a „szép”-re neveléssel (Kárpáti, 1997a).

A 18. században a céhekben folyó képzés során némely városi tanács rendeletben kötelezte bizonyos céhek mestereit, hogy inasaikat, segédeiket ipari tanfolyamokra járassák, ahol a mesterségük végzéséhez szükséges ismereteket sajátíthatják el, mely ismeretek átadása gépészeti, építészeti modellekkel (fa és gipsz) felszerelt rajztermekben zajlott. A vasárnapi rajziskolák megszervezése és az inasok részvétele kötelező volt. A rajziskolát müködtető városokban, egyetlen olyan céhlegény sem válhatott mesterré, aki nem tudta bizonyítvánnyal igazolni, hogy legalább egy évig rajzoktatásban vett részt (Kornis, 1913). Az 1861-ben kiadott rendelet a tanítóképzők I-II. évfolyamán heti 2 órában kötelezővé tette a rajzoktatást. Ez fontos pont a rajzoktatás történetében, bár hatása csak később érvényesülhetett (Tóth, 2006). A korabeli rajzoktatás meghatározó módszere a tanári mintarajzok másoltatása volt, ugyanakkor a geometriai modellek oktatásban való alkalmazását is szorgalmazták. A rajzoktatás korai periódusában nem választható el egymástól élesen a képi közlés két alapvető, az objektív (ábrázolás) és a szubjektív (kifejezés) vizuális kifejezési formának a tanítása.

A vizuális kommunikáció a magyar rajztanításban már az 1990-es évek kezdetén jelen van: a tantervben két másik fö témakör (a Képzőmüvészet és a Környezetkultúra) kellett nevesített, harmadik alternatíva, amelyre a kerettantervek és helyi tantervek épülhetnek. , tantervi alternatíva, amelyről módszertani tanulmányok készülnek. (Kárpáti, 1993, Kárpáti szerk., 1995b). A 21. század elején a vizuális kommunikáció, mint önálló tantárgy megjelenik a kommunikációs képzésekben is (pl.: Blaskó és Margitházi szerk., 2010;) és a rajztanárképzésben is (Gaul szerk., 2016).

A vizuális kommunikáció tehát változó hangsúllyal bár, de a 16. századi tudományos ábrázolási rendszerek megjelenésétől kezdve szerepelt először a müvészképzésben, majd a 19. századtól a pedagógusképzésben is. Hosszú fejlődési út volt a vázlatrajzoktól a reformpedagógiákon keresztül, míg eljutottunk a vizuális kompetencia keretrendszer megalkotásáig. A következőkben bemutatjuk a vizuális nevelés jelenlegi tantárgyi kereteit, a kitüzött célokat és a megfogalmazott követelményeket.

\subsection{A vizuális kommunikáció helye a rajz- és vizuális kultúra tantárgy kereteiben: tantervi célok és követelmények}

A kutatás során célkitüzéseink között szerepelt olyan diagnosztikus eszköz létrehozása, mely alkalmazható tanórai keretek között és alkalmazkodik a mindennapi tanítási gyakorlathoz. Ebben a részben áttekintjük az ehhez a célhoz tartozó tantárgyi és tantervi hátteret. A Nemzeti Alaptanterv (NAT) megjelenésével 1995-től lett a tantárgy neve a korábbi Rajz és műalkotások elemzése helyett „Vizuális kultúra”, (később, máig is: Vizuális kultúra és Rajz), amely a világ legkorszerúbb pedagógiai modelljei, a hasonló tartalmú amerikai és német tantervi reformokkal egy időben honosodik meg (Bodóczky, 2000, 2003; Pallag, 2006). A NAT-ban Vizuális kultúrára változott műveltségterület tartalmaiban a képzőművészet 
mellett a környezetkultúra és a vizuális kommunikáció is megjelenik. A vizuális kultúra tantárgy alkalmazkodik a 20. századi sokszínü és sokrétü korstílus kihívásaira, tananyagába egyaránt beleilleszkednek az akadémikus tudás elemei, és a közösségi háló informatikai alkalmazása is. Az új tantárgyban nem az esztétikai minőség az elődleges cél, és ezzel újraértelmeződik a vizuális nevelés lényege. A hangsúly az alkotó folyamatra, az egyéni alkotóképességre, a kreatív vizuális nyelvhasználatra kerül, amely egyszerre tanulságos és katartikus az egyén számára (Csíkszentmihályi, 1988; Souza, 1998; Steers, 2009; Freedman, 2010).

A vizuális kultúra műveltségterület oktatója a hagyományos képi nyelv megértését és használatát is tanítja, de az önkifejezés és annak új útjai egyre jelentősebb részt követelnek a tananyagban. A vizuális kultúra tanításával újraértelmeződik a müvészet fogalma, a tananyagba belefér a hétköznapi és hasznos tárgy is, valamint a társadalom problémáira reflektáló alkotások. A környezettudatos gondolkodás, a mindennapi élet vizuális problémáira fókuszáló környezettudatos „öko-müvészeti nevelés” is belefér a tantárgy kereteibe (Freedman, 2003; Kárpáti, 2011). Az angol és a német vizuális nevelés jellegzetessége, hogy a fogyasztói nevelés és a társadalmi érzékenység fejlesztésében rendkívül fontos vizuális kommunikációval kiemelten foglalkozik (Kárpáti és Gaul szerk., 2013, Kárpáti, 2018). Bodóczky is olyan rajzpedagógia megteremtését sürgeti, melyben a mintakövetést felváltja a problémamegoldás (Bodóczky, 2003)

A hazai vizuális nevelés aktuális követelményeit és tartalmait az érvényes kerettanterv határozza meg. Az oktatási miniszter 10/2003. (IV.28.) által megjelentetett kerettantervben ${ }^{10} \mathrm{a}$ vizuális kommunikáció a Vizuális kultúra tantárgy egyik fó területeként jelenik meg. A vizuális kommunikáció oktatása végighúzódik a közoktatás 1-12 évfolyamán, bár az első években nem kap hangsúlyos szerepet. Az első két iskolai évben a képi kifejezés szabad formái vannak fókuszban, a hatodik évfolyamtól pedig az elsajátítandó ismeretanyag középpontjában a térábrázolás áll (Kárpáti és mtsai, 2015). A kerettanterv a vizuális kommunikáción belül nagy hangsúlyt fektet a vizuális információk befogadására, értelmezésére, tudatosítására. A vizuális kommunikáció fejezetébe épült be a korábban külön tantárgy keretében tanított mozgóképkultúra és médiaismeret, melyben a vizuális kommunikáció képességelemei is megjelennek. A 3. táblázatban bemutatjuk a NAT-ban és a kerettantervben megjelenő képességelemeket és azok előfordulásának helyét az 1-6. évfolyamokon.

${ }^{10}$ Az oktatási miniszter 10/2003. (IV.28.) OM rendelete a kerettantervek kiadásáról, bevezetéséről és alkalmazásáról szóló 28/2000. (IX. 21.) OM rendelet módosításáról http://www.nefmi.gov.hu/kozoktatas/tantervek/oktatasi-miniszter-10 


\begin{tabular}{|c|c|c|c|c|}
\hline & \multicolumn{2}{|c|}{ KÉPESSÉGELEM } & $\begin{array}{l}\text { NAT }^{11} \\
2003 .\end{array}$ & $\begin{array}{l}\text { Kerettanterv } \\
12 \text { 2012. }\end{array}$ \\
\hline \multirow{3}{*}{$\begin{array}{l}\text { Vizuális } \\
\text { elemzés }\end{array}$} & ábr & sás,-értés & $1 ., 2 ., 3,4 ., 5 ., 6$. & 1.-2., 3-4., 5.-6. \\
\hline & tár & asás,-értés & & $1 .-2 ., 3-4 ., 5 .-6$. \\
\hline & mü & ás,-értés & & 1.-2., 3-4., 5.-6. \\
\hline \multirow{8}{*}{$\begin{array}{l}\text { Képalkotás, } \\
\text { komponálás }\end{array}$} & \multirow{3}{*}{ rajzolás } & vonalrajz & \multirow{3}{*}{$1 ., 2 ., 3,4 ., 5 ., 6}$. & $1-2,3-4,5-6$ \\
\hline & & tónusképzés & & $1-2,3-4,5-6$ \\
\hline & & kontraszt & & $1-2,3-4,5-6$ \\
\hline & \multicolumn{2}{|c|}{ festés } & $1 ., 2 ., 3,4 ., 5 ., 6$. & 1.-2., 3-4., 5.-6. \\
\hline & \multicolumn{2}{|c|}{ fotó } & & 1.-2., 5.-6. \\
\hline & \multicolumn{2}{|c|}{ montázs } & & 1.-2., 3-4., 5.-6. \\
\hline & & & 1.-2., 3-4., 5.-6. \\
\hline & \multicolumn{2}{|c|}{$\begin{array}{l}\text { sokszorosito eljarasok } \\
\text { ritmusképzés }\end{array}$} & & $1 .-2 ., 3-4 ., 5 .-6$. \\
\hline \multicolumn{3}{|c|}{ Asszociáció, vizuális fantázia } & & $1 .-2 ., 3-4 ., 5 .-6$. \\
\hline \multicolumn{3}{|l|}{ Léptékváltás } & & 1.-2., 3-4., 5.-6. \\
\hline \multicolumn{3}{|c|}{ Tárgyalkotás és formaalkotás } & & 1.-2., 3-4., 5.-6. \\
\hline \multirow{2}{*}{ Ábraalkotás } & Új & zöveg alapján & $1 ., 2 ., 3,4 ., 5 ., 6$. & $1 .-2 ., 3-4 ., 5 .-6$. \\
\hline & Ké & dkció & & 1.-2., 3-4., 5.-6. \\
\hline \multicolumn{3}{|c|}{$\begin{array}{l}\text { Manipuláció (nagyítás, kicsinyítés, csonkolás } \\
\text { stb.) }\end{array}$} & & 1.-2., 3-4., 5.-6. \\
\hline \multicolumn{3}{|c|}{ Anyag-, és eszközhasználat } & & 1.-2., 3-4., 5.-6. \\
\hline \multicolumn{3}{|c|}{ Vizuális dinamika, mozgás felismerése (idő) } & $1 ., 2 ., 3 ., 4 ., 5 ., 6$. & $3-4 ., 5 .-6$. \\
\hline \multicolumn{3}{|c|}{ Vizuális dinamika, mozgás ábrázolása (idő) } & & $3-4 ., 5 .-6$. \\
\hline \multicolumn{3}{|c|}{ Szimbolizáció } & $1,2,3,4,5,6$ & 1.-2., 3-4., 5.-6. \\
\hline \multicolumn{3}{|c|}{ Látványfelismerés és -értelmezés } & 5,6 & $1 .-2 ., 3-4 ., 5 .-6$. \\
\hline \multirow{4}{*}{ Modalitásváltá } & & Szó & $1 ., 2 ., 3,4 ., 5 ., 6$ & 1.-2., 3-4., 5.-6. \\
\hline & & kép & $1 ., 2 ., 3,4 .,, 5 ., 6$. & 1.-2., 3-4., 5.-6. \\
\hline & & kép & & 5.-6. \\
\hline & & s-kép & & $5 .-6$. \\
\hline
\end{tabular}

A vizuális felismerés, értelmezés, elemzés minden évfolyamon, de változó hangsúllyal szerepel. A 2012-es kerettanterv kiemelten fontosnak tartja a vizuális információk befogadását, értelmezését, tudatosítását. Mivel a 2012-es Vizuális kultúra kerettantervekben viszonylag nagyobb teret kapott a média, a képalkotás hagyományos formái közé belépett a fotózás, valamint a hang-kép transzformáció. Az információs csatornák ismerete és alkalmazása fontos eleme a követelményrendszernek. „A tantárgy fontosságát hangsúlyozza, hogy az információs csatornák gazdagodása a szöveges információ befogadása mellé felzárkóztatja a vizuális információk tudatos befogadásának fontosságát is, hisz az információk forrása és jellege alapján szöveg és kép együttes értelmezése napjainkban gyakoribb jelenség valós élethelyzetekben. A médiatudatosság fejlesztésének tehát egyre

${ }^{11}$ 243/2003. (XII. 17.) Korm. rendelet a Nemzeti alaptanterv kiadásáról, bevezetéséről és alkalmazásáról http://www.nefmi.gov.hu/kozoktatas/tantervek/nemzeti-alaptanterv-nat

${ }^{12} 51 / 2012$. (XII. 21.) számú EMMI rendelet - a kerettantervek kiadásának és jóváhagyásának rendjéről http://kerettanterv.ofi.hu/ 
fontosabb aspektusa már ebben az iskolaszakaszban is a vizuális megfigyelés és értelmezés segítségével megvalósuló médiahasználat és médiaértés." 13

A kerettantervben különböző hangsúllyal és elvárásokkal, de jelen lévő tartalom: az ábrák, ábrázolások felismerése, komponálás, vizuális dinamika felismerése, szimbolizáció, a szó-kép illetve a kép-szó leképezés. Ugyanakkor a forma- és arányérzék, a verbálisnonverbális és a vizuális kommunikáció kapcsolata alig, vagy egyáltalán nem jelenik meg a kerettantervekben. Szigorúan vett követelményeket nem határoz meg a kerettanterv, csak remélt eredményeket és fejlesztési irányokat. A kerettanterv a vizuális kommunikáció tárgykörébe nem vonja be a képzőmüvészeti alkotásokat, következetesen csak az ábrákra szúkíti a megismerési folyamatokat, mely nincs egyensúlyban a kognitív pszichológia eredményeivel (Sekuler és Blake, 2000; Goodman, 1977). A képzőmüvészeti alkotásoknak kommunikatív értéke lehet (pl. Van Gogh cipői), és mint ilyenek beemelhetök a tanult vizuális kommunikáció elemi közé (Panofsky. 1955/1984; Milbrandt, 1998).

Összességben megállapítható, hogy a magyar vizuális nevelés hagyományosan alkotásorientált, amelyben a diákok elsősorban az alkotó folyamat során szereznek befogadói élményeket. Nagy József rendszerében, összhangban a kortárs magyar müvészetpedagógia felfogásával, a vizuális önkifejezési képesség fejlesztése az alkotásban jelenik meg (Nagy 2000; Bodóczky, 2003). Az önálló befogadás képességének fejlesztése, lehetőségeinek feltárása további kutatásokat igényel. A vizuális kommunikáció tanítása szempontjából a kutatásaink hosszú távon hozzájárulhatnak a tartalmi és módszertani változásokhoz, valamint az oktatás eredményességéhez.

Nagy (2000) a személyiség funkcionális modelljében a kognitív kompetencia áll középen, melyhez a speciális kompetenciák kapcsolódnak (Nagy, 2000). Az esztétikai jellegü tevékenységek a személyes kompetencia körében szerepelnek, mely a kognitív és a szociális kompetenciával azonos súlyú, szoros kapcsolatot mutatnak. Ebben a kontextusban fogalmazza meg a vizuális kultúra feladatait. „A vizuális kultúra megszerettetésének feladata, hogy a befogadói élményszükséglet folyamatos és gondos kielégítése által a tanulókban attraktív attitüd alakuljon ki az esztétikailag értékes képek, tárgyak, azok alkotói iránt, hogy a környezetben föllelhető esztétikum, valamint a különböző müvészeti ágak legértékesebb hazai és nemzetközi alkotásainak megszerettetésével az iskoláztatás ideje alatt a vizuális esztétikai attitüdök átfogó készlete halmozódjon föl, amely elsajátított minták rendszereként az esztétikai érzék, izlés alapját képezi. Serdülökorban, különösen az utolsó évfolyamokon kezdődjék meg a vizuális alkotások esztétikai, stílusirányzati értelmezése, a vizuális esztétikai értékek iránti pozitív meggyözödés kialakítása, a viszonyulások tudatosítása: az esztétikai értékek tudatos megbecsülése, őrzése, védelme, a giccs elutasítása. Az iskolai nevelés törekedjen arra, hogy a tanulókban tartós érdeklödés alakuljon ki a vizuális kultúra egy vagy néhány területe iránt." (Nagy, 2000, 265. o.).

A jelenleg folyó tantárgypedagógiai fejlesztések a képességkutatásokra alapulnak. Ezektől joggal várható, hogy olyan tantervi alternatívákat kínálnak majd, amelyek alkalmasak a vizuális kommunikáció alkotó és befogadó (képi közlés és a képek befogadása) képességeinek a fejlesztésére egyaránt. A Bauhaus magyar mestereinek pedagógiájára alapoz az MTA-ELTE Vizuális Kultúra Szakmódszertani Kutatócsoportjának „Moholy-Nagy Modulok - a 21. századi képi nyelv tanitása" címü, tantervbe illeszthetö, vagy informális müvészeti oktatásban használható pedagógiai program-családja, amelyben a vizuális kommunikáció az első a négy, fejlesztés alatt álló modul közül. (Orosz és mtsai. megjelenés alatt).

13 51/2012. (XII. 21.) számú EMMI rendelet - a kerettantervek kiadásának és jóváhagyásának rendjéröl http://kerettanterv.ofi.hu/ utolsó letöltés 2018. április 12. 
„A tantárgypedagógiai és képességkutatásokat párhuzamosan, egymással összefüggésben végző kutatócsoporttal, négy „Moholy-Nagy modult” - a mester gondolatait kortárs neveléstudományi eredményekkel ötvöző képzési programot - dolgozunk ki, amelyek alapoznak az elmúlt évtizedek képességkutatásaira, és teret engednek a gyerek közösség és oktatója, az iskola és a település sajátos hagyományai, igényei megjelenítésére is: 1. Vizuális kommunikáció hagyományos és digitális képi eszközökkel, 2. Vizuális médiakultúra: a médiakompetencia és informatikai kompetencia integrált fejlesztése, 3. Környezetkultúra és tárgykultúra, közösségi tervezés és konstruálás, 4. A kortárs vizuális müvészet tanítása és felhasználása alkotási folyamatban. A Moholy-Nagy Vizuális Modulok lefelé és felfelé tovább építhetők, valamint a módszertani elvek mentén, a fejlődésvizsgálatok eredményeire építve további modulokkal bővíthetők. Közös jellemzőjük, hogy a hagyományos technikák és müfajok mellett, a kortárs vizuális kultúrához hasonlóan, integrálják a digitális, illetve multimediális képalkotási lehetőségeket is.

Négy modulunkhoz tantervet, minta tanmeneteket és oktatási segédeszközöket dolgozunk ki és tanári kézikönyveket készítünk. A programokhoz informális tanulási alkalmak (múzeumi foglalkozások, müemléktúrák, látogatások kézműves mühelyekben, képzőművészek mütermeiben stb.) is kapcsolódnak. A kutatás honlapján ${ }^{14}$ elérhető kézikönyvek, tanmenetek és közlemények remélhetőleg hatással lesznek majd a vizuális nevelés területén zajló pedagógiai innovációs munkára". (Célok a kutatás honlapjáról, 2017)

\subsection{A vizuális képességek értékelési lehetőségei a hazai és a nemzetközi pedagógiai gyakorlatban}

A vizuális kommunikációs képesség mérésének hagyományairól még nem beszélhetünk, de a vizuális képességek mérése nagy múlttal rendelkezik. A vizuális képességek a 21. században világszerte fontos iskolai fejlesztési területnek számítanak, ezért értékelésük számos országban a vizsgarendszer része (Boughton, 2004, 2013). A vizuális képességek értékelését két irány jellemzi. Az egyik a vizuális kultúra tantárgy keretében, az oktatási folyamat során megszerzett tudás mérése, a másik a tantárgytól függetlenül létező képességek vizsgálata.

A gyermekrajzokról szóló első mű szerzője Corrado Ricci (1887), aki a müvészettörténet oldaláról közelített a témához. Szerinte a a gyermekrajz fejlődése a művészettörténeti korszakok stílusainak fejlődésképét ismétli meg. A 20. század elején a kortárs képzőművészet és a gyermekrajzokon megjelenő kifejezési formák esetleges rokonságát vizsgálták, és párhuzamot vontak az őskori, valamint törzsi kultúrák és a naiv népi festőmüvészet alkotásaival. A gyermekmüvészetnek (Kinderkunst, child art, l'art enfantin, gyetszkoje isszkusztvo) nevezték a gyermekek alkotásait, melynek vizsgálata alapvetően az esztétikai szempontokra koncentrált (Kárpáti, 2013). A 20. század derekára vált világossá, hogy a gyermekkori virtuóz ábrázolási képességek nem prognosztizálják a vizualitásban kiemelkedő teljesítményt úgy, mint a zenei képességek, ugyanis számos fiatalon kiemelkedően ábrázoló alkotónak nagy jövőt jósoltak, de nem váltották be a hozzájuk füzött reményeket.

Számos gyűjtemény található gyermekrajzokból, de az alkotókról nem sokat tudunk (Child Study Movement, Dewey, vö. Koops és Zuckerman, 2003). Önmagukban az alkotások nem sok információt adnak a vizuális képességekről, annak fejlődéséről. Ebböl adódóan ezek a gyüjtemények nem lehetnek alapjai a vizuális képességek kutatásának. A tanulmányi versenyeken készült alkotásokból összeállított gyüjtemények többet árulnak el egy-egy korszak rajzpedagógiájáról, hiszen háttérinformációkat is tartalmaznak. Ilyen gyüjtemények Magyarországon is találhatók, például a Fővárosi Pedagógiai Szakszolgálat (FPSZ) és a

\footnotetext{
${ }^{14}$ A Moholy-Nagy Vizuális Modulok - a 21. század képi nyelvének tanítása” című, 2016-2020 között zajló kutatási program honlapja: http://vizualiskultura.elte.hu
} 
Moholy-Nagy László Iparművészeti Egyetem Vizuális Nevelési Gyűjteményének (MOME VNGY,) valamint az Országos tanulmányi Verseny Rajz szakágának díjnyertes anyagait tartalmazó gyüjtemény (Kárpáti és Köves, 2001). Ezeknek a gyüjteményeknek az anyagai későbbi kutatások tárgyai lehetnek.

A rajz tantervekben szereplő követelmények nagy része a képzőművészeti alkotáshoz kapcsolódó mütermi munka, amely alapvetően procedurális jellegü tudást feltételez és hagyományos a müvek és előképeik portfólió rendszerü értékelésével mérhetők. A portfólió egy meghatározott időszak alatt készített tanulói munkákból összeállított gyüjtemény, melyek konkrét feltételeknek felelnek meg. A portfólió kiegészülhet irányított beszélgetéssel, amely lehetőséget ad a müvek szemrevételezéssel nem érzékelhető alkotói problémáinak megismerésére és a tanulók meg nem valósult ötleteinek számba vételére is. Az értékelés szakértői megegyezésen alapuló szempontsor szerint, zsürizéses módszerrel történik. Számos hazai és nemzetközi vizsgálat igazolta a portfolióban összegyüjtött vázlatok, tervek és kész müvek képzett szakértőkkel végzett értékelésének megbízhatóságát (Dorn, Madeja, Sabol, 2003; Kárpáti és mtsai., 1998). Magyarországon a portfólió-értékelés beépült az érettségi vizsgába (Kárpáti, 1997b; Kárpáti és Gaul, 1998; Pallag, 2006). A portfóliók a legjobb, az átlagos és a gyenge megoldásokat tartalmazzák, melyekböl megbízható értékelési segédeszköz fejleszthető. A Nemzetközi Rajzi Érettségi (International Baccalaureate Program in Art Education) szintén alkalmazza a vizsgáztatásnak ezt a módját (Boughton, 2004).

A projektmódszer, mint értékelési eljárás, először Franciaországban terjedt el a vizuális neveléssel közvetlen kapcsolatban álló területen, a mérnökképzésben (Kárpáti, 1995b, 1997c, 1998; Kárpát és, Gaul, 1998). A projekt során a pedagógus feladatai mások, mint a tantárgyi órán. Nem a tantárgyi anyag, hanem a tevékenységek állnak a középpontban, a pedagógus ezeket a folyamatokat támogatja. A portfólióval szemben a projekt értékelés előnye, hogy nem csak a kész munkák alapján történik az értékelés, hanem a tervezés, a kivitelezés fázisait, tehát a folyamatot is figyelembe veszi, ami nagy jelentőségü a vizuális alkotásban. A módszer időigényes és függ a támogató pedagógus személyétől (Kárpáti és Gyebnár, 1996). A projekt módszerben az értékelés alapja lehet a tanár és a diák által közösen kialakított szempontsor. Itt a foglalkozás végén, a tanár és a diák közötti párbeszédben valósul meg az értékelés (Bodóczky, 2000; Freedman, 2010). Az értékelés során teret kapnak a tanár személyes nézetei, ízlése, tájékozottsága és ezekből következő szubjektív ítélete. Ugyanakkor, a projekt módszer jól kapcsolható képességtesztekkel történő értékeléshez is, amelyek részletes visszajelzést adnak a tanárnak arról, hogy melyik részképességet kell fejlesztenie (Babály és Kárpáti, 2016).

A vizuális képességek mérése hasonlóan más képességek méréséhez, hosszú utat járt be a mintarajzoktól a portfólióig és jelentős paradigmaváltás történt. Ugyanakkor az objektív értékelés hiánya nagy presztízsveszteséget okoz a tantárgynak, alapvető fontosságú a vizuális nevelés számára a lehető legobjektívebb értékelési rendszer kidolgozása. A rajztanárok közül egyre többen helyeslik a törekvést, hogy egy pontosabban meghatározott követelményrendszerrel növeljük a tantárgy hatékonyságát, és egyre többen csatlakoznak mérésekhez (Kárpáti és Kovács, 2009; Gardner, 1983, 1996; Gajdics, 2003).

Hasonló a helyzet Európa már országaiban is. Hazánkhoz hasonlóan Finnországban az érettségi bevezetésével növelik a tantárgy súlyát az oktatási rendszerben. Angliában 1998-tól létezik vizuális müvészeti érettségi. A német tartományokban is egyike a kötelezően választható vizsgatárgyaknak a rajz (Bodóczky, 2002a).

A 20. század második feléig a pedagógusok a gyermekrajzok értékeléséhez nem használtak teszteket. A pszichológiai teszteknek voltak ugyan rajzi vonatkozásai (ld. Goodenough), de ezek nem közelítettek az iskolai gyakorlathoz. Az ismeret-készség jellegü tantárgyak oktatásában az oktatási elemeket rendszerező és alkalmazhatóságukat figyelembe 
vevő modellek készítése rövid múlttal rendelkezik. A „rajzkészség” (drawing ability) standardizált értékelése a hatvanas években kezdődött az Egyesült Államokban, majd Hollandiában, Németországban, Angliában és a skandináv országokban, és jelentősen bővített értékelési célokkal, a vizuális müveltséghez kapcsolódó képességelemek széles körének értékelésével folytatódik napjainkban is (Boughton és Ligtvoet, 1996; Boughton, 2004; Haanstra és Schönau, 2007). Figyelmet érdemel a képes értékelési rendszer, amely a kritériumokat kifejező ábrákkal jeleníti meg. Hat országra kiterjedő vizsgálat szerint, ez diákoknak és tanároknak is egyszerüen kezelhető és hiteles eszköznek tünik mind az alkotás, mind a befogadás vizsgálatára. (Groenendijk és mtsai. 2018).

A magyar pedagógiai kutatók is csatlakoztak a kutatásokhoz: az oktatásban alkalmazható rajzi képességteszteket standardizáló nemzetközi csoportokhoz (Gerö, 1973/2007; Feuer, 2000; Kárpáti, 2001; Csapó, Varsányi, 1985); a konstruáló képesség angliai vizsgálataihoz (Gaul, 2001; Pataky, 2012); a projekt rendszerü értékelés holland és finn kidolgozóihoz (Bodóczky, 2002b; Kárpáti, 1997a, b). A térszemlélet (Séra, Gulyás, Kárpáti, 2002; Babály, Budai és Kárpáti, 2013, Babály és Kárpáti, 2016) vizsgálatai, melyek a vizuális nevelés tantárgyközi relevanciáját, a müszaki felsőoktatásra gyakorolt hatását igazolták. A vizuális képességek vizsgálatát aktualizálja az informatikai írástudáshoz (Tongori, 2012) szükséges vizuális képességelemek napirendre kerülése (térszemlélet, rugalmas memória, színérzékelés, képértelmezés). Az értekezés témáját szolgáló kutatás közvetlen előzményéről (Kárpáti és Gaul, 2011), melyben megjelenik a vizuális képességek vizsgálatán belül a vizuális kommunikáció vizsgálata, a 6.1. fejezetben írunk.

Az egyik legnagyobb mérés hazánkban 1988-1992-ben az öt alternatív vizuális anyagot kipróbáló Leonardo Program volt (Kárpáti, 1992a). A tanulók vizuális alkotói és befogadói képességeit, mentális fejlődésük néhány mutatóját a tananyagok bevezetése előtt és a kísérleti tanítás végén tesztekkel és tesztjellegü feladatokkal vizsgálták. Kidolgoztak a kutatásban használt, és a vizsgáztatásra és rendszeres értékelésre, tehetségdiagnosztikára is alkalmas pedagógiai mérőeszközöket. A program válaszokat keresett arra, mi várható a vizuális neveléstöl, ha esélyt kap az iskolában, valamint $\mathrm{mi}$ az, amire nem alkalmasak a mủvészetpedagógiai programok (Kárpáti és Gyebnár, 1996). A program felhívta a figyelmet arr, hogy a valamennyi müvészeti képzőmüvészeti témakört egy rövid tanórán bemutató módszer helyett sokkal hatásosabb a célirányos, egy területre koncentráló képzés. Az öt Leonardo program változat közül a vizuális kommunikáció, a környezetkultúra és a vizuális média (amely a program készülésének idején fotózást és videofilmezést jelentett), megalapozta a korábban említett három rajz tantervi alternatíva kidolgozását. A kutatás bizonyította, hogy a vizuális képességeket mérő tesztek alkalmasak a hitele és a rajzpedagógai elveinek is megfelelő feladatsorok és tesztek kidolgozására, és számos további kutatás kiinduló pontja lett.

2008-ban a Zuglói Pedagógiai Szakszolgáltató Központ megbízásából komplex feladatsorral vizsgálták a vizuális kompetenciát (Kárpáti, 2009). A kutatás során a vizuális képességrendszer minél több elemét akarták vizsgálni, ezért olyan mérőeszközt dolgoztak ki, amely több hagyományos értékelési formát ötvöz. A térszemlélet és a tervezés mérése mellett a harmadik részterület a vizuális közlés -jelalkotás és képi nyelv kommunikatív használata volt. Méréséhez a Kreatív Gondolkodás Teszt - Rajzi Feladat (A teszt neve: Kreatív Gondolkodás Teszt - Rajzi Feladat. (Test for Creative Thinking - Drawing Production, TCTDP, Urban, 2005, magyar adaptáció: Kárpáti és Gyebnár 1996, 2013). A tesztben a jelek között a gyermekrajzokban gyakran alkalmazott alapjelek (grafémák) szerepelnek (félkör, pont, két szögletes elem, íves vonal (,hullám”), szaggatott vonal, és a nagy szögletes képmezőn kívül egy kis nyitott szögletes forma)., ezért döntöttek a mérést vezetők a használata mellett. (Ezeket a jeleket mi is alkalmaztuk a dolgozatban leírt kutatás tesztjeiben.) 
A képelemek kulturálisan semlegesek, számos képi stílust követve egészíthetők ki. A keretbe foglalt képelemek inkább hasonlítanak egy rajzi feladatra, mint pszichológiai tesztre. $\mathrm{Az}$ értékelési kritériumokban szempontként szerepelt a humor, egységes kompozíció kialakítása, szimbólumok és jelek használata. Ezek a szempontok kapcsolatba hozhatók a képi kifejezési készség magasabb szintjeivel. A mérés hasonlóan a mi célkitüzésünkhöz, igazodott a tantárgyi keretekhez és 45 perc állt rendelkezésre a teszt kitöltéséhez. A mérőeszköz alkalmas egy-egy korosztály vizuális kompetenciájának mérésére, hiszen a kreativitás komponenseken túl a komponálás, téri megjelenítés és az érzelmek, hangulatot kifejezését is értékeli. A vizsgálatok egyik eredménye, ami a kutatásunk szempontjából fontos megállapítás, hogy a vizsgált kiskamasz korosztályban a képességrendszer legfejlettebb része a képi kifejezés volt, amelyet az ettől jól elkülöníthető, a hétköznapi helyzetekben alkalmazott a képi kommunikáció követett (Kárpáti, 2009).

A vizsgálatok során egyértelmüvé vált, hogy a vizuális alkotó és befogadóképesség olyan rendkívül összetett rendszer, melyet diagnosztikus célra célszerü képességterületenként mérni. A 2010-2014 között lezajlott, „A vizuális képességek értékelése” címü, az SZTE-MTA Képességkutató Csoportja által irányított és az ELTE Vizuális képességkutató csoportja által megvalósított kutatás céljai között szerepelt a vonatkozó szakirodalom feltárása és elemzése, a magyar kultúrában érvényes vizuális képességlista elkészítése és ennek alapján értékelő feladatok készítése (Kárpáti és Gaul, 2010, 2011). A kutatás során összeállított framework jellegü vizuális képességrendszert lefedő struktúrát használtuk a dolgozat témáját adó kutatásunk során, melynek bővebb kifejtése a kutatásunkat részletesen ismertető fejezetben található. 


\section{A digitalizáció beépülése a vizuális kultúrába és kommunikációba, a technológiai alapú mérés-értékelés}

A kutatás során alkalmazott tesztek kitöltése online közegben valósult meg. A környezet meghatározó része a méréseknek, ezért fontosnak tartjuk röviden ismertetni, hogyan illeszkedik a digitalizáció a vizuális kultúrához és kommunikációhoz. A gyors technológiai fejlődés jelentősen megváltoztatta a gazdasági és társadalmi folyamatokat egyaránt és meghatározza hétköznapi életünk szinte minden aspektusát és jelentősen befolyásolja a vizuális világhoz való viszonyunkat. Napjaink gyermekeinek a számítógép virtuális, vizuális világa az élet része. Az „új képkorszak” (Peternák, 1989). generációjának a vizuális nyelv a gondolatok, ismeretek, érzelmek kifejezésének természetes módja. Egyre több olyan közösségi oldal jelenik meg és válik egyre népszerübbé, mely csak képek megosztására alkalmas (például Pinterest, Instagram). A képzőmüvészet gyakran használt eszközévé váltak a különböző digitális hardverek és szoftverek. A képernyőn megjelenő több dimenzióban rejlő lehetőségek egyértelmüen felébresztik az igényt a vizuális nyelv ismereteinek elektronikus tesztelése iránt. A digitális eszközök beépülnek a hagyományos technikák közé és digitális rajzversenyeket szerveznek (Példák: 2004-máig is: Középiskolai Rajzverseny, 1995-től: Országos Középiskolai Tanulmányi Verseny - Rajz, 2008-máig is: Fővárosi Rajzverseny; 2010 Helsinki: Identitás kifejezése átalakított digitális fotókkal; 2015. „Digitális képalkotórendszerek múvészi célú felhasználása a középiskolában” fővárosi verseny középiskolásoknak).

A képi kifejezés útjai nem állíthatók rangsorba hagyományos és digitális képalkotás szerint. A hagyományos technikákra jellemző a pszichomotoros képességekre való közvetlen hatás, az alkotások és az alkotó folyamatnak az egyedisége, a kreativitás megkérdőjelezhetetlen, a motívumok gazdagságának csak a megvalósíthatóság szab határt. A digitális képalkotásban az eszköz hangsúlyosabb szerepet játszik a képességekkel szemben, az alkotások sokszorosíthatók, kollektivitás jellemzi és a motívumok adaptálhatók, szerkeszthetők. Az új eszközökkel új müfajok, új kifejezési formák jelennek meg (például digitális vizuális napló, kép-blog, video-blog). A digitalizálás megkönnyíti a képek manipulációját. Eltünik a határ alkotó és befogadó között, és felborítja a hagyományosan stabil, maradandó, befejezett müvek világát (Mitchell, 1994). Mára egyértelmüvé vált, hogy a képzőmüvészet egyedisége nem csorbul a géppel alkotott képek, a digitális kultúra, a müvészi multimédia-alkotások másolhatóságával. Új, anyagtól független értékelési szempontok megjelenését hívják életre, hiszen az esztétikai színvonal, a gondolati tartalom, a kreatív kompozíció bármely módon megnyilvánulhat. Digitális környezetben is létezik már rajzos személyiségteszt a Vass Zoltán, Sváb Péter, Bagdy Emőke és Vargha András által létrehozott „Psychogalaxy”"15 nevü weboldalon.

Az infokommunikációs eszközök használata természetesen jelentős hatást gyakorol az oktatásra is. Meghatározza egyaránt a rendszerszintü és az osztálytermi folyamatokat (Kárpáti és mtsai., 2008; Molnár, 2007, 2011; Ollé és mtsai., 2013). Egyre nagyobb teret kap a technológiára épülő mérés. A technológiai alapú mérés-értékelés magában foglal minden olyan mérést, melyet különböző infokommunikációs eszközök segítségével végeznek (Csapó, Molnár és R. Tóth, 2008, Csapó és mtsai., 2011). A folyamat során az adatfeldolgozás, statisztikai elemzések és visszajelzések, valamint adatfelvétel egyaránt számítógépen történik.

A technológiai alapú tesztelés számos előnnyel ját. A papíralapú mérések mérőeszközeinek az előállítása, az adatok rögzítése, logisztikai problémák, kiértékelés nehézkessége sok problémával és költséggel jár, de talán a legnagyobb problémát fejlődési lehetőségeinek kimerülése jelenti. A digitális tesztelés is eszközigényes (hardware, software), mely eszközök beszerzése sok költséggel jár, viszont hosszú távú megtérüléssel lehet

\footnotetext{
${ }^{15}$ http://www.psychogalaxy.hu/ Az emberi kapcsolatok pszichológiai kutatása
} 
számolni. Az eszközök fejlesztésénél külön figyelmet kell szentelni a programok megfelelő kalibrálására, a rendszer biztonságára (illetéktelenekkel szemben). A tesztek eljuttatása rendeltetési helyükre többféleképpen valósulhat meg: egyik a vizsgaközpontba telepített számítógépes rendszerrel, másik a hordozható médiumok (CD, DVD, memóriakártya stb.) használatával. Az online tesztelés elvileg bárhol történhet, nem kell szállítani. Ebben az esetben a kritikus pontot az adatforgalom sebessége jelenti. Napjainkban az online tesztelés a leggazdaságosabb megoldás (Molnár, 2007, 2010). A gazdaságossági előnyökhöz tartozik az előkészítéssel és a pontozással nyert idő.

A számítógépes tesztelés pozitívumaihoz sorolható a kiértékelési folyamat felgyorsulása, mely mind a diák, mi a pedagógus számára hatásosabb, a szinte azonnali visszacsatolás nagyobb motivációt jelent a továbbhaladásra. $\mathrm{Az}$ adatok komplexebben kezelhetök, pontosabban lehet beazonosítani a teljesítményeket, nyomon követhetöbb egy-egy osztály, tanuló vagy tanár munkája. Az elektronikus mérés-értékelési rendszerek esetében lehetőség van minden egyes kérdést nemcsak egy adott pontértékhez, nehézségi fokhoz, hanem akár közvetlenül valamely kimeneti követelményhez (például a kerettanterv egyes soraihoz) hozzárendelni, ezek alkalmazásával a különbözőfeladatok megoldásának eredménye már nem szubjektív értékelés alapját képezi.

A technológiai alapú mérések elterjedését bizonyítja, hogy a PISA mérések is technológiai alapon valósulnak meg 2015-től (OECD PISA ${ }^{16}$ )(Balázsi, Ostorics, Szalay, 2007). A hazai Országos Kompetenciamérés esetén is lépéseket tettek a technológia alapú mérésre való áttérésre (Balázsi és mtsai., 2014; Berényi, 2010; Molnár és mtsai., 2015). A diagnosztikus méréseknek iskolai szinten van fontos szerepük, hiszen közvetlen visszajelzést adnak a diákoknak és a pedagógusoknak. Az automatikus kiértékelés során a teljesítmények a tesztkitöltést követően azonnal megjelennek, így biztosított a közvetlen visszacsatolás, mely pozitív hatást gyakorol a teljesítményre. Az SZTE Oktatáselméleti Kutatócsoportja által kifejlesztett eDia ${ }^{17}$ rendszer (Molnár, 2015a, 2015b) a diagnosztikus és formatív mérésnek jellemző és jól müködő hazai példája. A kutatásunk szintén ebben a rendszerben valósult meg.

A technológia lehetővé teszi az adaptív tesztelést, mely nagy lépés a mérésértékelésben. A fix tesztekben minden tanuló ugyanazokkal a feladatokkal ugyanolyan sorrendben találkozik, ezért vannak olyan feladatok, amelyek nem differenciálnak és nem bírnak diagnosztikus erővel. Az adaptív tesztek kitöltésekor a tanulók azokat a feladatokat oldják meg, amelyek közelebb állnak a képességszintjükhöz, így ezek a tesztek illeszkednek a tanulók képességeihez, pontosabb becslést tudnak adni az egyének képességszintjéröl (Magyar, 2012; Molnár, 2013). Az adaptív tesztelés nagy lehetőségeket rejt a vizuális képességek mérésében, a jövőbeli feladatokhoz tartozik.

A technológia alapú mérések kiértékelését gazdagítja a log fájlok elemzése, melyek olyan kiegészítő információkat szolgáltatnak, amelyek a papíralapú méréskor nem elérhetők (tesztelési idő, feladatban eltöltött idő (5. fejezet)). Kiegészítve webkamerával vagy szemmozgásokat vizsgáló eszközökkel lehetőség van további információt szerezni a tanulók feladat megoldási stratégiáiról, valamint jelentősen növelhetik a tesztek továbbfejlesztését.

A virtuális környezet természetesen egy sor megvizsgálandó problémát is felvet, de egyre több kutatás folyik a technológiaalapú mérés-értékelés megvalósítására, a felmerülő kérdések megválaszolására. (Nyéki, 2005; Csapó, Molnár és R. Tóth, 2015). Az eltérő IKT ismeretek hatásáról különböző kimenetelü tanulmányok születettek. A háttérváltozók vizsgálatakor a számítógép-használat gyakorisága, fejlettségi szintje nem bizonyult meghatározó teljesítménymódosító tényezőnek O'DWyer és munkatársai kutatásában, viszont az ellenkezőjét igazolta Martin (O'Dwyer és mtsai, 2008; Martin, 2009). A feladatok technikai jellegủ meghatározottsága erőteljes befolyással bír, melyben a következő tényezők emelhetők

\footnotetext{
${ }^{17}$ Elektronikus diagnosztikus mérési rendszer (eDia) http://edia.hu/.
} 
ki: szöveg és a kép egyensúlya, a kijelző mérete, felbontás, betük típusa és mérete, a megjelenítés és annak sebessége, a lapozás (Chen és mtsai, 1996, Waters és Pommerich, 2007). A nyíltvégü, szövegalkotó feladatok alkalmazása nem megoldott. A vélemények megoszlanak arról, hogy csak a zárt feladatok alkalmazásával mennyire szegényedik a mérési kultúra. A legfőbb érvek a zártvégü tesztek mellett, hogy jobban biztosítják az objektivitást és több kérdés feltételére alkalmasak. Mind a papíralapú, mind az elektronikus közegben használt feladatok esetén az egyértelmüség, pontos feladatkiadás egyaránt fontos jellemzői a teszteknek (Nyéki, 2005). Nem egyértelmü annak eldöntése, hogy melyik tesztelés bizonyul könnyebbnek: vannak tanulmányok, melyek a tanulók jobb teljesítményét mutatják a hagyományos módszerekkel végzett méréseken (Way, Davis és Fitzpatrick, 2006), és vannak, amelyek az elektronikus teszteket minösíti könnyebbnek (Clariana és Wallace, 2002).

$\mathrm{Az}$ elektronikus tesztelés a vizuális kultúrában is egyre nagyobb szerepet kap. Napjainkban több vizuális képességeket mérö kutatás zajlik online közegben (Tóth, Kárpáti és Molnár, 2017; Babály és Kárpáti, 2016; Kárpáti és mtsai., 2015). Tesztjeink néhány feladata bekerült a jelenleg zajló, a német 15 évesek körében 3 állam 7000 tanulója részvételével végzett vizuális műveltség (visual literacy) vizsgálatba (Frick, 2018). A vizuális képességrendszerben a korábban ismertetett vizsgálatok alapján jól elkülöníthető befogadói és alkotói képesség alrendszerek (3.4. fejezet) közül a színbefogadás és színértelmezés, a térérzékelés és a vizuális kommunikáció a befogadói képességelemeinek mérésére alkalmazzuk a technológiát. Napirenden van azonban az eDia rendszer fejlesztése, melynek során egyre több vizuális alkotó jellegü feladat készítése is lehetővé válik. Az alkalmazás fejlesztésével bővül a mérhető képességek sora, színesednek a feladatok, és egyre pontosabb képet, több információt kaphatunk a vizuális képességekről. A technika lehetővé teszi a jövőben a vizuális képességek mérésének összekapcsolását más mérési területeken (például induktív gondolkodás, zenei képességek) végzett mérések eredményeivel. Ez nagy előrelépést jelent majd a vizuális képességek mélyebb, pontosabb feltárásában és megértésében és egyúttal támogatja a diszciplínák közötti éles határok megszünését, mely megfelel a 21. század elvárásainak és a vizuális kommunikáció diszciplínákon túlmutató vizsgálatainak.

A következő fejezet részeiben a kutatás előzményeinek és folyamatának leírása után, közöljük az eredményeket. Az eredmények két nagy csoportot alkotnak, egyrészt a mérőeszközökre vonatkoznak, másrészt a teljesítmények és a háttérváltozók összefüggéseire. 


\section{Az empirikus vizsgálatok koncepciója}

\subsection{A kutatás céljai, relevanciája}

Dolgozatunk elméleti részében (2. fejezet) kifejtjük, hogy a vizuális kommunikáció az egyik legvitatottabb, még formálódó diszciplínák közé sorolható, létjogosultsága viszont napjainkban megkérdőjelezhetetlen. A kutatási téma aktuális problémákra reflektál, ugyanis napjainkban a verbalitással szemben elötérbe került a vizualitás, amelynek térhódítása nem csökken, hanem napról napra nő (Achen, 1981; Szabó és Kardos, 2014). A vizuális nevelés és a müvészeti ismeretek tanításának keretei és céljai megváltoztak (4. fejezet): az alkotóképesség fejlesztése mellett egyre fontosabb feladat lett a vizuális befogadás, megismerés és kommunikáció elsajátításának támogatása, a befogadó képességek tudatos fejlesztése. Mindennapi életünkben a vizuális kommunikáció került elötérbe, szinte nincs olyan gyerek, aki ne használná a média vizuális eszközeit (Apscott, 2001)

A vizuális befogadó képesség fejlesztése nem korlátozódik a müalkotásokra. A mindennapi életben használt digitális közlések formái és szerepe, valamint a tömegkommunikáció vizuális üzenetei is megtanulandó képi „nyelvjárások”. A digitális eszközök elterjedésével a képalkotási kedv nem csökkent, hanem nőtt. A digitális képalkotás eszközei a fiatalok mindennapos használatában a képi kommunikációt az írásos közléssel legalábbis egyenrangúvá tették, vizsgálata ezért is különösen fontos. (Kárpáti, 2016). Tíz éves korukra a gyerekek a médiumok és az ezeknek megfelelő jelrendszer, a szimbólumokban gazdag gépi-képi kultúra széles választékát ismerik és használják. (Szabó és Kardos, 2014). A digitális pedagógia egyértelmüen a vizualitásra épül. (Tóth, 2008; Vig, 2008).

Az értekezés témáját adó kutatás a Szegedi Tudományegyetem dinamikus mérési projekt második szakasz része ${ }^{18}$, melyben a alkalmazkodva az Elektronikus diagnosztikus mérési rendszer (eDIA rendszer) ${ }^{19}$ lehetőségeihez, befogadói jellegű feladatokat fejlesztettünk. A feladatok alapját képező képességstruktúrát, az első kutatási szakasz feladatainak kipróbálási eredményei alapján optimalizált vizuális framework alapján alakítottuk ki (Kárpáti és Gaul, 2011), mely képességrendszereket a 6.1. fejezetben ismertetünk. Kutatási témánk relevanciáját támasztja alá az a tény is, hogy a jelenleg érvényes Kerettantervben $(2012)^{20}$ a vizuális kommunikáció a Vizuális kultúra tantárgyon belül külön területként jelenik meg, kiemelten figyel a vizuális információk befogadására, értelmezésére és tudatosítására.

A kutatás hat, egymással szorosan összefüggő célt határozott meg:

1. A vizuális kommunikációs képesség tartalmának meghatározása, részképesség rendszerének leírása.

2. Olyan diagnosztikus mérőeszközt fejlesztettem, amely idő és költséghatékony formában, megbízható eredményekkel támogatja a pedagógiai munkát. Az eszköz fejlesztéséhez célom volt a vizuális kommunikáció vizsgálatára alkalmas befogadói feladatok kidolgozása 4-6. évfolyamos tanulók részére. Olyan tesztek kialakítására törekedtem, melyeknek kitöltéséhez elegendő egy tanóra, és egyszerre teljes osztályok vehessenek részt az adatfelvételben.

3. Az online tesztek alkalmazása a vizuális nevelésben még ritka, de fontosnak tartott módszer (Frick, 2018). Az osztályszintü adatfelvétel, az automatikus kódolás és értékelés, valamint azonnali visszajelzés egyértelmüen támogatja az online tesztek mindennapi gyakorlatban való alkalmazását. A kidolgozott feladatok kipróbálása és a

\footnotetext{
${ }^{18}$ Diagnosztikus mérések fejlesztése (2009-2015) TÁMOP-3.1.9-08/1-2009-0001 (1. fázis) és a TÁMOP-3.1.911/1-2012-0001 (2. fázis)

${ }^{19}$ Elektronikus diagnosztikus mérési rendszer (eDia) http://edia.hu/.

${ }^{20}$ 51/2012. (XII. 21.) számú EMMI rendelet 2. melléklete http://kerettanterv.ofi.hu/02_melleklet_58/index_alt_isk_felso.html
} 
nagymintás mérés lebonyolítása online környezetben, az eDIA diagnosztikus értékelő rendszerben történt.

4. A mérőeszköz segítségével leírjuk a 4-6. évfolyam vizuális kommunikációjának sajátosságait. Fontosnak tartjuk, hogy a tesztben szereplő feladatok lehetőség szerint a vizuális kommunikáció képességstruktúra minél több területét lefedjék. Így részletesebb képet kaphatunk a képesség szerkezetéről, összefüggéseiről. Mivel egyegy részterület megbízható mérésére meghatározott mennyiségü feladatra van szükség, ezért négy részképesség méréséhez négy feladattípust dolgoztam ki (ezek részletes kifejtését ld. 7.3. fejezetben).

5. További cél, hogy hozzájáruljunk az objektív, diagnosztikus információk visszajelentésével a tanulók fejlesztéséhez, a kiemelkedően jól teljesítő tanulók azonosításához. A tesztek melletti háttérkérdőívek kitöltésének célja, hogy feltárható legyen a vizuális kommunikációs képesség összefüggésrendszere a kognitív, az affektív és a szociális háttérváltozókkal.

6. Kutatásunk célja, olyan pedagógiai javaslatok kidolgozása, amely hozzájárul a mindennapi vizuális közlés hatékonyabb oktatásához a Vizuális kultúra tantárgy keretein belül.

7. Kutatásunk hosszú távú célja a vizuális kultúra értékelési kultúrájának gazdagítása.

\subsection{Kutatási kérdések}

A kutatási kérdéseink a vizuális kommunikációs képesség mérési lehetőségei és a vizuális kommunikációs képesség köré szerveződnek. Egyrészt a vizuális kommunikációs képességet mérő tesztek működésére, másrészt a vizuális kommunikációs képesség szerkezetére vonatkoznak. Kiterjednek a mért háttérváltozók és a vizuális kommunikációs képességet mérő teszten elért teljesítmények kapcsolatára, illetve a képesség fejlődésének tendenciáira.

\section{A méröeszközre vonatkozó kérdések}

- Megvalósítható-e a vizuális kommunikációs képesség online mérése iskolai környezetben?

- Megbízhatóan mérik-e a tesztek itemei a vizuális kommunikációs képességet a vizsgált korcsoportban?

○ Milyen a vizuális kommunikációs képességet mérő tesztek belső konzisztenciája?

○ Megfelelők-e a vizuális kommunikációs képességet mérő tesztek pszichometriai jellemzői?

A vizuális kommunikációs képességre, azok fejlettségére és a háttérváltozók kapcsolatára vonatkozó kérdések

- Megállapítható-e az életkori csoportokon belül különbségek a teszteken elért teljesítmények vonatkozásában?

- Kimutatható-e nemek szerinti különbség a vizuális kommunikációs képességet mérő tesztben és annak szubtesztjeiben?

- Összefügg-e a vizuális kommunikációs képességet mérő teszteken elért teljesítmény a tantárgyi osztályzatokkal és az attitüdökkel az egyes évfolyamokon?

- Befolyásolják-e a számítógépes tapasztalatok a vizuális kommunikációs képesség teszten kimutatott fejlettségét?

- Kapcsolatban állnak-e a vizuális kommunikációs képességet mérő teszteken elért teljesítmények egyéb mért háttérváltozókkal?

\subsection{Hipotézisek}

H1: A tesztekkel megvalósítható a vizuális kommunikációs képesség online mérése iskolai környezetben. 
H2: A tesztekkel megbízható becslés adható a tanulók vizuális kommunikációs képességének fejlettségi szintjéről, a tesztek pszichometriai jellemzői megfelelök.

H3: A tesztekben elkülöníthetők részkonstruktumok, melyek között van összefüggés.

H4: Az egyes életkorok között nincs jelentős különbség a vizsgált évfolyamokon.

H5: A vizuális kommunikációs képességet mérő teszteken elért teljesítmény és a szociális háttérváltozók között van kapcsolat.

H6: A nemek között nincs szignifikáns különbség a vizuális kommunikációs képességet mérő teszteken elért teljesítményekre vonatkozóan.

H7: Az osztályzatok és a vizuális kommunikációs képességet mérö teszteken elért eredmények között közepes erősségü korrelációk figyelhetők meg.

H8: A vizuális kommunikációs képességet mérő teszten elért eredményre nincsenek hatással az előzetes számítógépes tapasztalatok. 


\section{A vizuális kommunikációs képesség mérésére szolgáló eszközök kidolgozása, a fejlesztés folyamata}

A mérések az Szegedi Tudományegyetem Oktatáselméleti Kutatócsoport TÁMOP3.1.9-11/1-2012-0001 (2. fázis) ${ }^{21}$ pályázatok által támogatott "Diagnosztikus mérések fejlesztése" címü program keretében valósultak meg, mely kutatás az egész országra kiterjed, több müveltségi területet érint. Három nagy müveltségi területen (olvasás-szövegértés, matematika, természettudomány) kívül további 14 területen történtek fejlesztések. A vizuális képesség közül a térszemlélet és a vizuális kommunikáció területekre terjed ki a fejlesztés, melynek során, online alkalmazható diagnosztikus méröeszközök készülnek az adott terület mérésére.

\subsection{A kutatás elözményei}

Az értekezés témájául szolgáló kutatás közvetlen előzménye a 2009-2011-ben zajlott vizuális képességek értékelését célul kitüző TÁMOP 3.1.9 kutatás ${ }^{22}$, melynek koncepcióját a nemzetközi és hazai szakirodalom, valamint a hazai tapasztalatok alapján Kárpáti Andrea és munkatársai dolgozták ki. A koncepció középpontjában egy, a tananyagtervezésben és értékelésben használható képességrendszer és a képességelemeket fejlesztő és értékelő feladatrendszer kidolgozása állt. A képességrendszert 12 szakértőből álló csoport dolgozta ki, a részképességeket a nemzetközi szakirodalom és a hazai vizuális nevelési tantervek alapján állították össze és négy iterációban, viták során szükítették. (Kárpáti és Gaul, 2011, 2012, 2013) A Magyar Vizuális Képesség Framework (4. táblázat) elemeinek vizsgálatakor a Nemzeti alaptantervben (2012) szereplő részképességeket állították a középpontba. A mérhető képességeket rendszerbe szervezték, melynek alapján a szakértők három életkori intervallumnak (1-2.; 3-4. és 5-6. évfolyamosoknak) megfelelően feladatokat írtak. A feladatok között voltak alkotó és befogató feladatok egyaránt. A folyamat során 180, szakértők által lektorált feladat született, melyből 90 került be a 2009-2011-es mérésekbe. A vizsgálat N=7289 elemszámú mintával zajlott.

A kutatás során az alkotó és a befogadó részképességeket egyetlen rendszerbe foglalták. Nem a NAT által meghatározott témakörök: a tárgykultúra, képzőmüvészet, vizuális kommunikáció részterületek képezték a felosztás alapját, hanem azok a képességek, amelyeket ezeken a területeken fejleszteni lehet. A kutatás során különálló képességalrendszernek tekintették a vizuális befogadó képességet Kárpáti Andrea korábbi vizsgálataira hivatkozva (Kárpáti, 2001, 2003). Ennek vizsgálatára az alkotói képességekkel együtt igen nehéz és csak néhány képességelemre szorítkozhat (Kárpáti és Kovács, 2009), ezért külön feladatsorokat terveztek hozzá. A tanterv alkotói képességfejlesztő fókuszának megfelelően, az alkotói feladatok domináltak. A feladatok írásakor arra törekedtek, hogy minden képességelemet lefedjenek, ugyanakkor egy-egy tevékenységet nem lehet izoláltan szerepeltetni a vizuális feladatokban, ezért minden feladathoz több képességelemet rendeltek.

4. táblázat TÁMOP 3.1.9. kompetenciamérés vizuális képességrendszere

\begin{tabular}{ll}
\hline \hline $\begin{array}{l}\text { A vizuális képességrendszer } \\
\text { elemei }\end{array}$ & Az elem meghatározása \\
\hline \hline 1. Megfigyelés & $\begin{array}{l}\text { A látottak lényeges vonásainak felismerése, a megfigyelés } \\
\text { szempontjainak gazdagsága }\end{array}$ \\
\hline $\begin{array}{l}\text { 2. Látványfelismerés és } \\
\text { értelmezés }\end{array}$ & $\begin{array}{l}2.1 \text { Felismerés: a jelentés érzékelése, azonosítása. } \\
\text { S.2 Értelmezés: következtetések levonása látványok, képek, } \\
\text { szövegek alapján., nézöpontváltás képessége (látványok }\end{array}$ \\
\hline & \\
\hline $\begin{array}{l}{ }^{21} \text { http://edia.hu/?q=hu/index } \\
\text { Diagnosztikus mérések fejlesztése (2009-2015) TÁMOP-3.1.9-08/1-2009-0001 (1. fázis) és a TÁMOP- }\end{array}$
\end{tabular}


elképzelése más nézőpontból, szövegek látvánnyá alakítása, igény a „más nézőpont felvételére, a statikus vagy a dinamikus állapotok felismerése és érzékeltetése, stb.

3. Vizuális emlékezet (tapasztalatok látványok elöhívása)

4. Vizuális elemzés
5. Formaalkotás a síkban (2D)

és térben (3D)

6. Manipulációk

7. Rekonstrukciós (transzponáló) képesség

8. Absztrakció

9. Szimbólumképzés

10. Ábrák alkotása

és értelmezés
Látványok, képek (hosszú és rövid távú) felidézésének képessége

Információk rendszerezése, analógiák felismerése csoportosítás, halmazképzés

Megfigyelt és elképzelt formák megjelenítése

Nagyítás, kicsinyítés, csonkolás, kiegészítés, stb.

Részletek alapján az egész megalkotása, rajz alapján téri alakzat elkészítése, térbeli konstrukció 2D-ben való megjelenítése

Lényegkiemelö, egyszerüsítő, redukáló képesség

9.1 Jelalkotás

9.2 Jelképek, allegóriák, vizuális metaforák képzése

10.1 Ábraalkotás: konvenciókon alapuló, szabályokhoz igazodó, jelentést hordozó, közlő és magyarázó rajzok, szerelési ábrák, folyamat ábrák „olvasásának" és létrehozásának képessége, valós vagy elképzelt viszonyok, kapcsolatok megjelenítésének képessége

10.2 Ábraértelmezés: magyarázó rajzok, szerelési ábrák, folyamat ábrák stb. olvasásának képessége

11. Nem vizuális jellegü Adatok, összefüggések, fogalmak, struktúrák, arányok képi információk megjelenítése megjelenítése

12. Időbeli folyamatok Állapotok változásai, mozgásfázisok megjelenítésének megjelenítése képessége

13. Modalitásváltás Különbözö észlelési tapasztalatok, modalitások (látás, hallás, tapintás, szaglás, ízlelés) áttétele, más rendszerben való rögzítése (pl. hanghatások, tapintási tapasztalatok vizuális "fordítása", felidézése).

14. Képalkotás, komponálás Adott képmezőben, koherens ábrázolás létrehozása. Kiemelés, a képelemek szervezése, figyelemirányítás, figyelemvezetés.

Térkapcsolatok, térbeli viszonyok, térbeli tagolódások

15. Téralakítás létrehozása, ábrázoló, kifejező céllal.

Tárgytervezés, -szerkesztés, -alkotás, konstrukciók létre

16. Konstruálás hozása különböző anyagokból és célokra.

17. A síkbeli és térbeli A megjelenítés, a kifejezés céljának megfelelő árnyalt vonal vizuális megjelenítő, kifejező tónus, szín, forma, stb. használat, (mintakövetéstől az önálló eszközök adekvát használata alkalmazásig)

Fantázia, divergens gondolkodás, rugalmasság, asszociációs

18. Kreativitás képesség

19. Anyagalakítás, Anyagok és eljárások ismerete; rendeltetéshez, eszközhasználat alkalmazkodás a kifejezési célokhoz, anyag és eszközválasztás / használat 
A 19 képességelemből álló rendszernek megfelelő feladatok alapján, az eredmények klaszter elemzésével a vizuális kompetencia négy fö területét határozták meg (5. táblázat). (Kárpáti és Gaul, 2011):

1. Vizuális megismerés (észlelés, emlékezés, értelmezés) / tanulási képességek

2. Problémamegoldó képesség

3. Vizuális alkotó, kifejező képesség

4. Vizuális kommunikációs képesség

5. táblázat Képességterületek (elméleti klaszterek) és a hozzájuk tartozó részképességek.(Kárpáti és Gaul, 2011)

\begin{tabular}{lll}
\hline \hline & Képességterületek neve (klaszterek) & Klaszterhez tartozó képességek \\
\hline \hline 1 & $\begin{array}{l}\text { Vizuális megismerés (észlelés, } \\
\text { emlékezés, értelmezés) }\end{array}$ & $1,2,3,4,11$ \\
\hline 2 & $\begin{array}{l}\text { Ábrázolási konvenciók, technikák } \\
\text { használata }\end{array}$ & $5,6,7,8,10,11,12,13,14,15,16,17,19$ \\
\hline 3 & Vizuális kommunikáció & $10,11,12,16,19$ \\
\hline 4 & Alkotás & $9,14,15,16,18,19$ \\
\hline
\end{tabular}

A kutatás során felépített teljes képességstruktúrát (4. táblázat) vettük alapul, amikor az értekezés tárgyát képező kutatás során, meghatároztuk a vizuális kommunikáció során aktivizálódó képességelemeket. Mivel vizsgálatunkban a befogadói alrendszer került a fókuszba, elsősorban a befogadói részképességeket vettük számításba érőeszközünk kialakításakor. A Magyar Vizuális Képesség Framework 19 képességeleme közül a vizuális kommunikációs képességhez saját vizsgálataink megtervezésekor öt részképességet rendeltünk:

- Ábrák alkotása és értelmezés

- Nem vizuális jellegü információk megjelenítése

- Időbeli folyamatok megjelenítése

- Konstruálás

- Anyagalakítás, eszközhasználat

A vizuális kommunikációs képességhez tartozónak tekintett részképességeket a képességrendszer feladatai 92 esetben tartalmazták. (6. táblázat). A feladatok több képességhez is tartoznak, ezért magasabb a kapcsolatok száma az összes kipróbált feladat számánál. A 92 kapcsolódási pontot 46 feladat képezi.

6. táblázat A vizuális kommunikáció részlépességeit mérő feladatok darabszáma 2010-ben

\begin{tabular}{llllll}
\hline \hline & $\begin{array}{l}10 . \text { Ábrák } \\
\text { alkotása } \\
\text { és } \\
\text { értelmezés }\end{array}$ & $\begin{array}{l}11 . \text { Nem } \\
\text { vizuális } \\
\text { jellegü } \\
\text { információk } \\
\text { megjelenítése }\end{array}$ & $\begin{array}{l}12 . \quad \text { Időbeli } \\
\text { folyamatok } \\
\text { megjelenítése }\end{array}$ & $\begin{array}{l}16 . \\
\text { Konstruálás }\end{array}$ & $\begin{array}{l}19 . \\
\text { Anyagalakítás, } \\
\text { eszközhasználat }\end{array}$ \\
\hline $\begin{array}{l}\text { Feladat } \\
(\mathrm{db})\end{array}$ & 23 & 16 & 12 & 10 & 31 \\
\hline
\end{tabular}

\subsection{A pilot mérés keretei, a mérőeszköz fejlesztése}

Az értekezés tárgyát képező kutatás az 6.1. fejezetben ismertetett kutatási elözmények eredményeinek és feladatainak áttekintésével kezdődött, melyben elsősorban alkotói jellegü feladatokkal, papír alapon vizsgálták a vizuális képességeket. A vizsgálat alapján meghatároztuk a vizuális kommunikációs képesség részképességeit, amelyek vizsgálatára 
online közegben is értelmezhetö befogadói jellegü feladatokat fejlesztettünk. Ezeket az új fejlesztésü befogadói feladatokat online alapon és a papíralapon is kipróbáltuk.

A feladatok alapját képező képességstruktúrát az első szakaszban kialakított képességrendszer (4. táblázat) alapján képeztük, figyelembe véve az akkori kipróbálási eredményeket. Ezt a struktúrát a 7. táblázatban közöljük. Az új képességrendszer szükebb, összesen nyolc képességelemet tartalmaz. Kivettük azokat az elemeket, amelyek a vizuális kommunikáció szempontjából nem relevánsak, illetve azokat, melyek kifejezetten a papíralapú alkotói feladatokhoz illeszkednek (pl. anyagalakítás és eszközhasználat). A fennmaradt részképességekkel alkottuk meg a vizuális kommunikációs képesség rendszerét. (7. táblázat)

7. táblázat $A$ vizuális kommunikációs képességet mérö tesztek pilot mérés során alkalmazott képességrendszere (Kárpáti és mtsai., 2015 in.: Csapó és Zsolnai, 2015.57.o.)

\begin{tabular}{|c|c|c|}
\hline "Képességelemek & Fogalommagyarázat & Müveletek, példák \\
\hline Felismerés & $\begin{array}{l}\text { A látottak lényeges vonásainak } \\
\text { felismerése; a jelentés, a vizuális } \\
\text { probléma érzékelése, azonosítása; } \\
\text { múalkotások témájának, múfajának, } \\
\text { azonosítása. }\end{array}$ & $\begin{array}{l}\text { - diszkrimináció } \\
\text { - azonosítás } \\
\text { - összehasonlítás } \\
\text { - információ gyüjtése }\end{array}$ \\
\hline Értelmezés & $\begin{array}{l}\text { Következtetések levonása látványok, } \\
\text { képek, szövegek alapján, nézőpontváltás } \\
\text { képessége. } \\
\text { Ábraolvasás: konvenciókon alapuló, } \\
\text { szabályokhoz igazodó, jelentést hordozó, } \\
\text { közlö és magyarázó rajzok, ábrák, } \\
\text { olvasása; Adatok, összefüggések, } \\
\text { fogalmak, struktúrák, arányok értelmezése } \\
\text { (pl. grafikon, használati utasítás); valós } \\
\text { vagy elképzelt viszonyok, állapotok } \\
\text { változásai, mozgásfázisok, vizuális } \\
\text { dinamika, kapcsolatok megjelenítésének } \\
\text { értelmezése }\end{array}$ & $\begin{array}{l}\text { Látványok elképzelése } \\
\text { más nézőpontból, statikus } \\
\text { vagy dinamikus állapotok } \\
\text { felismerése és } \\
\text { érzékeltetése, } \\
\text { általánosítás, } \\
\text { csoportosítás, becslés } \\
\text { A valóság és a vizuális } \\
\text { jelek közötti kapcsolat } \\
\text { megteremtése }\end{array}$ \\
\hline Vizuális elemzés & $\begin{array}{l}\text { Forma- és kompozícióelemzés képi } \\
\text { eszközökkel, történeti és stíluselemzés }\end{array}$ & Forma- és funkcióelemzés \\
\hline Leképezés & $\begin{array}{l}\text { Látványok vizuális megjelenítése. } \\
\text { A síkbeli és térbeli vizuális megjelenítő, } \\
\text { kifejező eszközök adekvát használata. } \\
\text { Koherens ábrázolás létrehozása. }\end{array}$ & Rajzolás, festés, mintázás \\
\hline $\begin{array}{l}\text { Absztrakció, } \\
\text { elvonatkoztatás }\end{array}$ & $\begin{array}{l}\text { Jelek, formák alkotása lényegkiemeléssel, } \\
\text { egyszerüsítéssel, redukálással. } \\
\text { Abraalkotás: } \\
\text { - } \quad \text { konvenciókon alapuló, szabályokhoz } \\
\text { igazodó, jelentést hordozó, közlö és } \\
\text { magyarázó rajzok, szerelési ábrák, } \\
\text { folyamat ábrák létrehozása; } \\
\text { - adatok, összefüggések, fogalmak, } \\
\text { struktúrák, arányok képi } \\
\text { megjelenítése; } \\
\text { - valós vagy elképzelt viszonyok, } \\
\text { állapotok változásai, mozgásfázisok, } \\
\text { kapcsolatok megjelenítése }\end{array}$ & $\begin{array}{l}\text { (Pl. térkép útvonalrajz) } \\
\text { Közlő és magyarázó } \\
\text { rajzok, szerelési ábrák, } \\
\text { folyamatábrák, adott } \\
\text { térben vagy képmezőben }\end{array}$ \\
\hline Szimbolizáció & $\begin{array}{l}\text { Jelképek, allegóriák, vizuális metaforák } \\
\text { képzése }\end{array}$ & $\begin{array}{l}\text { (Pl. logó, embléma, címer } \\
\text { tervezés) }\end{array}$ \\
\hline
\end{tabular}




\begin{tabular}{lll}
\hline \hline Modalitásváltás & Zenék, szövegek, fogalmak vizuális & Kép, ábra $\rightarrow$ szó, szöveg \\
& megjelenítése. & $\begin{array}{l}\text { Kép } \rightarrow \text { ábra } \\
\text { Kép, ábra } \rightarrow \text { hang } \\
\text { Kép, ábra } \rightarrow \text { íz, illat, } \\
\text { tapintás }\end{array}$ \\
& & $\begin{array}{l}\text { Komponálás rajz, festés, } \\
\text { mintázás, konstruálás } \\
\text { közben }\end{array}$ \\
\hline $\begin{array}{l}\text { Komponálás síkban } \\
\text { és térben }\end{array}$ & $\begin{array}{l}\text { Kiemelés, a képelemek szervezése, } \\
\text { figyelemirányítás, figyelemvezetés. }\end{array}$ & Vizuális dinamika (Idő és ritmus) \\
& megjelenítése. & \\
\hline
\end{tabular}

A pilot mérések elsődleges célja olyan, a mindennapi pedagógiai gyakorlatban is alkalmazható feladatokat tartalmazó, online közegben müködő, vizuális kommunikációs képességet mérö eszköz kialakítása és kipróbálása volt a 4-6. évfolyamokon. A pilot az értekezés témájául szolgáló nagymintás mérés előkészítése volt. A feladatok fejlesztésekor, valamint a képességrendszer átsrukturálása során áttekintettük és figyelembe vettük a 2012-es NAT-hoz tartozó Kerettanterv Rajz és vizuális kultúra tantárgy kimeneti követelményeit (tevékenységeket és tudáselemeket) (3. táblázat), melyet részletesen ismertetünk a 4.2. fejezetben. A 3. táblázatban jól látható, hogy a vizuális felismerés, értelmezés, elemzés minden évfolyamon, de változó hangsúllyal szerepel. Ebből következően méréseink során mindhárom megjelenik az egyes évfolyamokon.

Szempontként szerepelt a mérőeszköz kialakítása során az, hogyan jelennek meg a vizuális kommunikáció tevékenységei a mérés-értékelési szakirodalomban és a hazai, illetve nemzetközi képességvizsgálatokban (4.3.fejezet) (pl. USA: Boughton, 2004, Finnország: Laitinen, 2013, Egyesült Királyság: Steers, 2013). Figyelembe kellett vennünk a vizsgált korosztály rajzfejlődési sajátosságait, melyet részletesebben a 3.5. fejezetben vázolunk fel (Kárpáti, 2001, Kárpáti és Pethö, 2012). Fontos volt számolnunk az online felület által szabott határokkal és lehetőségekkel is (Molnár, Csapó és R.Tóth, 2008).

A pilot során fejlesztett vizuális kommunikációs képességet mérő eszközök részben építenek az előző (6.1. fejezet) mérési szakaszban kipróbált feladatokra, részben új fejlesztés eredményei. A digitális környezethez adaptálható feladatokat kiválogattuk és átdolgoztuk, Azokat a feladatokat tudtuk tehát megtartani, melyek alkotó jellegüből átalakíthatók voltak befogadói feladatokká. Az előző szakasz nagymintás mérésében szereplő 90 feladat közül 46 kapcsolódott a vizuális kommunikációhoz, melyekből 8 feladatot alakítottunk át online közegben alkalmazhatóvá. Egyrészt az akkori mérés során elkészült gyerekrajzokat felhasználva lehetett a nyitott, alkotó feladatokat zárt, befogadó jellegűvé alakítani, másrészt a képelemzéshez kapcsolódó feladatok képanyagát és kérdéseit felhasználni. Az így képzett feladatok zárt típusúak. A feladatmegoldó tevékenység szerint a következő típusok jelennek meg a tesztekben: alternatív választás, feleletválasztás, szelektálás, csoportba sorolás, sorképzés és -- a leggyakrabban előforduló -- párosítás.

A mérőeszközök feladatstruktúrája mintegy leképezi egyrészt a vizuális kommunikáció szakirodalom által meghatározott összetevőit, másrészt a vizuális kommunikációs képesség rendszert (7. táblázat). A vizuális kommunikáció területei úgy jelennek meg, hogy a feladatsorok itemei változatos módon tükrözzék a vizuális kommunikáció közoktatásban elvárt összetevőit. Mindhárom évfolyam számára két tesztvariáns készült. Mivel hasonló, online mérési eredményekre és tapasztalatokra nem építhettünk, minél több feladat kipróbálása volt célszerü, hogy lássuk, melyik típusú feladat működőképes, és melyik nem. Számos azonos feladatot kipróbáltunk mindhárom évfolyamon, hogy becslést tudjunk arra vonatkozóan adni, hogy a különböző korosztályok között vannak-e mérhető eltérések. Összesen 81 itemet jelentő 41 feladat szerepelt a pilot mérésekben. 
A pilot mérésben vidéki általános iskolák 4., 5. és 6. évfolyamai vettek részt. A pilot folyamán a mérőeszközt párhuzamosan kipróbáltuk online közegben az e Dia rendszerében és papíralapon. A papíralapú tesztek kitöltésekor a képeket vetítettük és a kérdésekre a tanulók a feladatlapon válaszoltak. Ebben az esetben az irányító tanár addig vetítette a képeket, míg minden tanuló válaszolt a kérdésekre. A személyes adatfelvétel alkalmával feljegyezhettük a tanulók kérdéseit, megfigyelhettük motiváltságukat, közvetlen reakcióikat az egyes feladatokra. A személyes megfigyelések során regisztráltuk, hogy milyen és mennyi kattintást, próbálkozást célszerü engedni a kitöltés során. A vizsgálati minta összetételét és a felvett tesztek típusát a 8 . táblázat tartalmazza.

8. táblázat A vizuális kommunikációs képességcsoport próbamérési időpontjai és mintája

\begin{tabular}{lccccc}
\hline \hline Mérés ideje & Teszt típus & Iskolatípus & Település típus & Évfolyam & Fő \\
\hline \hline 2013. május & eDia (online) & $\begin{array}{c}\text { hagyományos } \\
\text { tantervú általános } \\
\text { iskola }\end{array}$ & megyeszékhely & $4 . ; 5 . ; 6$. & 79 \\
\hline 2013.október & $\begin{array}{c}\text { eDia (online) } \\
\text { papír alapú }\end{array}$ & $\begin{array}{c}\text { hagyományos } \\
\text { tantervú általános } \\
\text { iskola }\end{array}$ & város & $5 ;, 6$. & 43 \\
\hline 2013.december & eDia (online) & $\begin{array}{c}\text { hagyományos } \\
\text { tantervú általános } \\
\text { iskola }\end{array}$ & város & $5 . ; 6$. & 16 \\
\hline & & & & & \\
\hline
\end{tabular}

\subsection{A pilot mérés eredményei}

A papíralapú és az online mérés teszten elért eredményei között nem volt szignifikáns különbség (9. táblázat).

9. táblázat A papíralapú és az online pilot mérés eredményei 5. és 6. évfolyamon

\begin{tabular}{lcccc}
\hline \hline & $\begin{array}{c}\text { Papíralapú teszt } \\
\text { eredménye 5. } \\
\text { évfolyam }\end{array}$ & $\begin{array}{c}\text { Online teszt } \\
\text { eredménye 5. } \\
\text { évfolyam }\end{array}$ & $\begin{array}{c}\text { Papíralapú teszt } \\
\text { eredménye 6. } \\
\text { évfolyam }\end{array}$ & $\begin{array}{c}\text { Online teszt } \\
\text { eredménye 6. } \\
\text { évfolyam }\end{array}$ \\
\hline \hline Átlag & 55,83 & 56,44 & 62,90 & 65,37 \\
Szórás & 23,47 & 29,46 & 32,34 & 37,18 \\
\hline
\end{tabular}

Nem jelentett gondot a tanulóknak az online felületen való eligazodás és nem volt idegen a technika használata. A megoldási idő sokkal rövidebb volt az online mérés esetén, gyorsabban, saját tempójukban haladtak a tanulók. A papíralapú mérési eljárást nehezíti, hogy a tesztek képekre épülnek, melyek színes nyomtatása nagy költségigényü, és vetített képek használata papíron kitöltött mérölapokkal csökkenti a kitöltés sebességét. A vizuális területeken a digitális mérés alkalmazása egyértelműen előnyös. A tesztkitöltés sebességéről kapott információ segít megtalálni azt a lehető legmagasabb itemszámot, ami még lehetővé teszi a mérőeszköz alkalmazását tanórai időkeretek között.

A pilot mérés megmutatta, hogy online felületen majdnem kétszer annyi itemet lehet tesztenként alkalmazni, mint papíralapon, mely item növekedés a tesztek reliabilitását fogja növelni. Az online felület előnyei közé sorolható, hogy a tanulókat hangalámondások segítik a szövegek feldolgozásában. A hangalámondást a tanulók tetszőlegesen megállíthatták vagy elindíthatták. A fülhallgatók hozzáférhetőségét meg kell oldani, enélkül a teszt csoportos adminisztrálása nehézkes, a tanulók egymást zavarják a hangzó instrukciók lejátszásával. A pilot mérés eredményei alapján megállapítottuk, hogy a vizuális képességek online mérése hasznos értékelési mód lehet a pedagógiai gyakorlat számára. 
A személyes adatfelvétel lehetőséget biztosított, hogy információt gyüjtsünk a tanulók tesztröl alkotott véleményéröl. Bizonyos hétköznapi témák (pl. Palacsintasütés), és az absztrakt, szokatlan feladatok (pl. Zene, Szavak és ábrák) határozottan motiválóan hatottak a gyerekekre. Hasonló figyelhető meg a fantáziájukat megmozgató, gazdag képi világot feldolgozó témák esetén is (pl. Görög istenek). A véglegesített feladatok az 1. mellékletben találhatók. A továbbiakban az online pilot mérés eredményeire fókuszálunk, hiszen ez készíti elő közvetlenül a nagymintás mérésünket. A pilot mérés statisztikai mutatóit és a tesztváltozatok reliabilitását évfolyamonkénti bontásban a 10. táblázat foglalja össze.

10. táblázat A vizuális kommunikáció teszt tesztváltozatai és reliabilitásuk

\begin{tabular}{lcccc}
\hline \hline Teszt megnevezése & N (fö) & Itemek száma & Cronbach- $\alpha$ & Átlag (szórás) \% \\
\hline \hline 4. évfolyam A teszt & 19 & 16 & 0,83 & $63,32(32,16)$ \\
4. évfolyam B teszt & 16 & 17 & 0,47 & $59,21(33,45)$ \\
5. évfolyam A teszt & 20 & 14 & 0,25 & $63,35(34,12)$ \\
5. évfolyam B teszt & 23 & 21 & 0,60 & $56,44(29,46)$ \\
6. évfolyam A teszt & 23 & 19 & 0,57 & $65,37(37,18)$ \\
6. évfolyam B teszt & 8 & 25 & 0,90 & $40,36(29,40)$ \\
\hline
\end{tabular}

A 10, táblázatban jól látható, hogy a 4. évfolyam B tesztvariáns mutatója nagyon alacsony. Ebben a tesztben lévő itemek közül többet végleg töröltünk, valamint jelentősen átalakítottuk a bent maradtakat. Hasonló a helyzet az 5. évfolyam A tesztvariánsának feladataival is.

A feladatok közül kiemeljük a hang-kép modalitásváltás itemeit (Zene1), melyet minden évfolyam megoldott. Ez azért volt szükséges, mert ennek mérésére sem a hazai, sem a nemzetközi gyakorlatban nem találtunk példát. A vizuális és auditív elemek összekapcsolása új elemként jelenik meg az értékelésben, és a kerettantervek követelményeiben szintén szerepel. A feladatban egy harsonával megjelenített dallam és/vagy ritmussort párosítanak a tanulók elemi vizuális jelekkel. A feladat próbamérésének eredményeit tartalmazó 11. táblázat szemlélteti, hogy a feladat elvárásainknak megfelelően müködik (Cronbach- $\alpha=0,7)$. Ennek alapján a végleges tesztben is használható, illetve kialakítható volt ennek mintájára újabb feladat a megbízhatóságának javítása érdekében.

11. táblázat A Zene címü feladat pilot mérésének eredményei és mutatói

Cronbach- $\alpha \quad$ Átlag (szórás) \%

\begin{tabular}{lcc}
$\mathrm{N}=66$ & & \\
\hline \hline zene_1 & 0,74 & $52,13(47,40)$ \\
zene_2 & 0,58 & $62,44(49,39)$ \\
zene_3 & 0,53 & $52,31(47,11)$ \\
zene_4 & 0,66 & $77,37(50,23)$ \\
zene_teljes (4 item) & 0,7 & $61,28(48,42)$ \\
\hline
\end{tabular}

Visszatérve a teszteken nyújtott teljesítményekre, a teljesítmény szintet vizsgálva elmondható, hogy 90\% fölött egyik évfolyamon sem teljesítettek, de magas a 60-70\%-ot elérők aránya (5. ábra). A tanulók teljesítményét ábrázoló hisztogram oszlopai eltolódnak a normál eloszlástól a nagyobb értékek felé. Bár módusza még a középértékeken belül marad, de a jobbra tolódás arra utalhat, hogy a tesztek a tanulók képességéhez képest könnyünek bizonyultak. Ezt korrigáltuk azzal, hogy azokat az itemeket kivettük a tesztekből, melyeket a tanulók 90\%-ánál többen hibátlanul oldottak meg. 
Az egyértelmüen, szinte hiba nélkül kitöltött itemeknek nincs differenciáló erejük, ezért ezeket kihagytuk a tesztelésböl vagy jelentősen átalakítottuk. Szintén eltávolítottuk azokat az itemeket, melyeket egy tanuló sem vagy csak nagyon kevés tanuló volt képes megoldani és ellentétesen korreláltak a teljes teszttel. Ezekben az itemekben nehezen értelmezhetö szövegek és nehezen elkülöníthető képrészletek voltak. Ez utóbbi esetén befolyásoló tényező a monitoron megjelenő kép minősége, ami miatt a képrészletek elkülönítése nem egyértelmü, ez csökkenti az objektivitást.

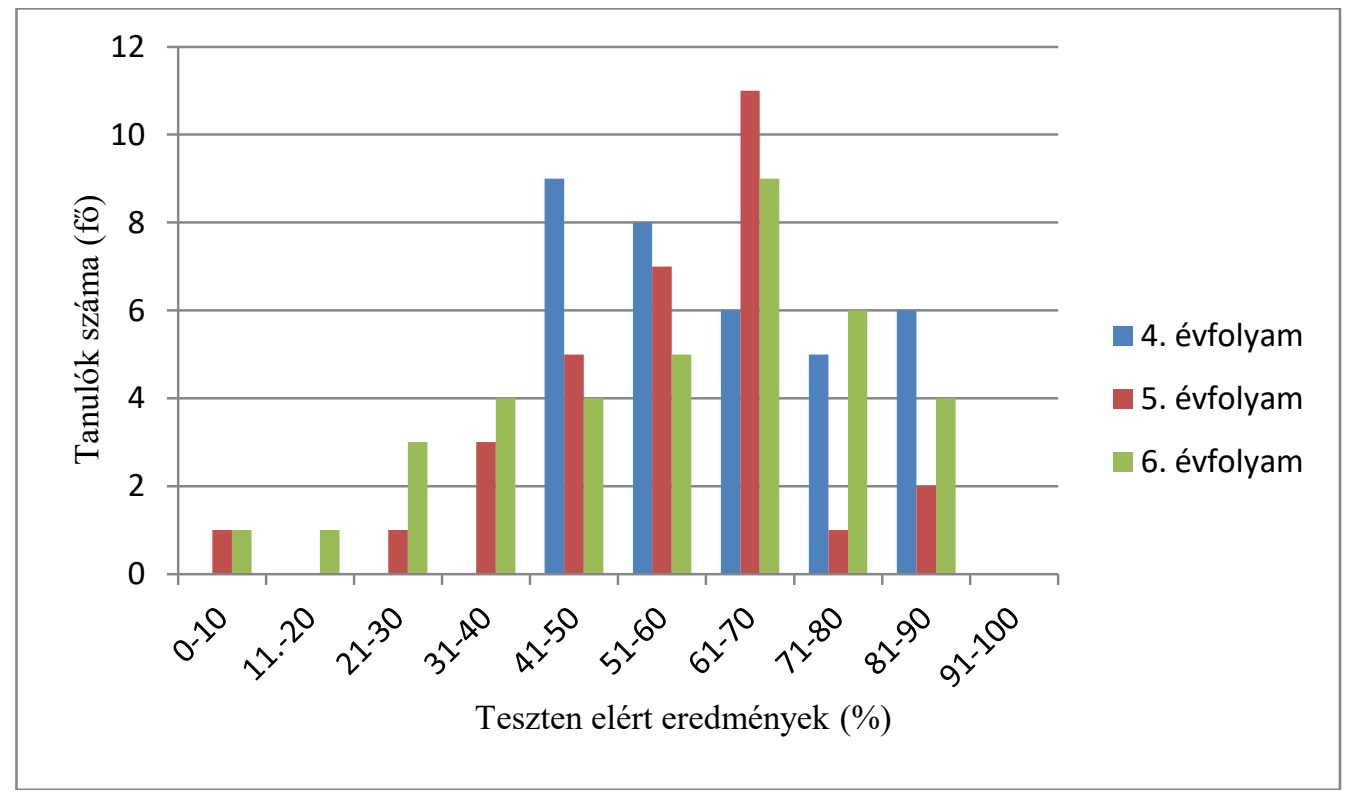

5. ábra A vizuális kommunikáció pilot mérés eredményeinek gyakoriság eloszlása évfolyamonként.

A negyedik évfolyam teszteredménye a legproblematikusabb. Az ábrán jól látható, hogy a teszt nem megfelelöen különíti el az egyes életkori csoportokhoz tartozó tanulókat, ezért számos módosítást hajtottunk végre. A vizuális felismerés és modalitásváltás itemei annyira könnyünek bizonyultak, hogy egyet tartottunk meg belölük. A vizuális elemzés viszont nehézséget okozott, ezért csak azt az itemet tartottuk meg, mely szorosan kapcsolódott egy másikhoz és mindhárom évfolyam tesztjében benne maradt. Hasonlóan jártunk el a többi évfolyam esetén is. Megvizsgáltuk, mely itemek alkalmasak arra, hogy információt adjon az adott részképességröl. Ötödik és hatodik évfolyamon a vizuális elemzéshez, valamint a szimbolizációhoz tartozó itemek közül kellett többet kivennünk a tesztből.

A pilot mérésben kiderült, hogy a vizuális kommunikációs képesség részképességei közül melyik mérhető leginkább és melyik kevésbé az általunk fejlesztett online tesztek segítségével, illetve melyek azok, melyeket más úton elindulva, más jellegü itemekkel célszerü vizsgálni. A pilot mérés után a nagymintás mérés előtt, a képességstruktúrát módosítottuk. Létrehoztunk egy framework jellegü, a pilot mérés eredményeire épülő részképességekből és képességszintekből álló optimalizált taxonómiát, melyet a 7.2. fejezetben ismertetünk. A pilot mérés tanulságai alapján módosított, véglegesített feladatok az 1. mellékletben találhatók. 


\section{A vizuális kommunikációs képesség online diagnosztikus mérése a 4-6. évfolyamon}

\subsection{A minta}

A mintavétel egysége az iskolai évfolyam volt. A vizsgálatainkat a 4., 5. és 6. évfolyamosok körében végeztük. A 4. évfolyamos mintát 432 tanuló alkotta, átlagéletkoruk 10,5 év (szórás 0,60). A 4. évfolyamos tesztet összesen 13 iskola 21 osztálya töltötte ki. Az 5. évfolyamos mintában 14 iskola 26 osztályának 338 tanuló vett részt, átlagéletkoruk 11,4 év (szórás 0,88). A 6. évfolyamosokat 486 tanuló képviselte, 16 iskola 26 osztályából. A hatodikosok átlagéletkora 12,5 év (szórás 0,89). Összesen 1256 tanuló vett részt a kutatásban.

Az intézmények a mérésekhez önként csatlakoztak, így a minta nem reprezentatív sem a településtípus, sem iskolatípus vonatkozásában. A területi eloszlást a 12. táblázat ismerteti. Az eredmények alapján nem vonhatunk le következtetséeket a teljes populációra, de jó kiindulópontot szolgáltat a mérőeszköz további fejlesztéséhez és alkalmazásához, valamint jól tükrözi a populáció sokszínűségét. Kutatásunk céljai között nem szerepelt az országos reprezentativitás biztosítása, hiszen vizsgálatunk nemzetközi viszonylatban is ritka kísérlet volt a vizuális kommunikáció részképességének mérésére gyermekeknél. Célunk az volt, hogy minél megbízhatóbb és minél egyszerübben használható diagnosztikus eszközt adjunk a képességet fejleszteni kívánó rajztanárok kezébe. Az eredmények bemutatásakor ezért nem törekszünk általánosítására.

12. táblázat A mérésben résztvevő intézmények területi eloszlása

\begin{tabular}{|c|c|c|c|c|}
\hline & 4.évfolyam & 5. évfolyam & 6. évfolyam & Összesen \\
\hline $\begin{array}{l}\text { Közép-Magyarország } \\
\text { (Budapest, Pest megye) }\end{array}$ & 149 & 55 & 119 & 323 \\
\hline $\begin{array}{l}\text { Közép-Dunántúl (Fejér, } \\
\text { Komárom-Esztergom, } \\
\text { Veszprém megye) }\end{array}$ & 63 & 28 & 65 & 156 \\
\hline $\begin{array}{l}\text { Nyugat-Dunántúl (Győr- } \\
\text { Moson-Sopron, Vas, Zala } \\
\text { megye) }\end{array}$ & - & - & - & - \\
\hline $\begin{array}{l}\text { Dél-Dunántúl (Baranya, } \\
\text { Somogy, Tolna megye) }\end{array}$ & 38 & 42 & 46 & 126 \\
\hline $\begin{array}{l}\text { Észak-Magyarország (Borsod- } \\
\text { Abaúj-Zemplén, Heves, } \\
\text { Nógrád megye) }\end{array}$ & 59 & 77 & 117 & 253 \\
\hline $\begin{array}{l}\text { Észak-Alföld (Hajdú-Bihar, } \\
\text { Jász-Nagykun-Szolnok, } \\
\text { Szabolcs-Szatmár-Bereg } \\
\text { megye) }\end{array}$ & 67 & 99 & 98 & 264 \\
\hline $\begin{array}{l}\text { Dél-Alföld (Bács-Kiskun, } \\
\text { Békés, Csongrád megye) }\end{array}$ & 51 & 40 & 43 & 134 \\
\hline
\end{tabular}

A minta nemek és korosztályok szerinti összetételének vizsgálata a 13. táblázatban látható. Közel ugyanannyi lány és fiú vett részt a kitöltésben. A három évfolyamhoz születési idejük alapján hat korosztály tartozik, melyböl a 14-15 évesek a minta 3\%át jelentik. Az évfolyamok bontása korosztályokra azért indokolt, mert a vizuális képességekben két éves ciklusban jelentkezik kimutatható fejlődés (Löwenfeld, 1970), ezért ha az egyes évfolyamok közötti különbség nem is jelentős, a korosztályok között jelentkezhet kimutatható fejlődési trend.

A minta nemek szerinti vizsgálata szintén releváns, amennyiben még nincsenek információink a nemek közti különbségekről a vizuális kommunikációs képességben. A 13. táblázat a minta nemek szerinti eloszlását is tartalmazza. A térszemlélet képességben például eltérés mutatkozik a nemek között, ezért fontos megvizsgálnunk más területeket is (Molnár, 
2007). Az eredmények alapján hatékonyabb fejlesztési programokat dolgozhatunk ki, hiszen a téri képességeknél is a nemi különbségek figyelembe vétele vezetett a korábban publikáltaknál sokkal hatékonyabb fejlesztési programok kidolgozásához. (Babály és Kárpáti, 2016)

13. táblázat A minta életkor és nemek szerinti eloszlása

\begin{tabular}{|c|c|c|c|c|c|c|c|c|}
\hline $\begin{array}{l}\text { Születési } \\
\text { év }\end{array}$ & $\begin{array}{c}10 \\
\text { évesek } \\
2005\end{array}$ & $\begin{array}{c}11 \\
\text { évesek } \\
2004\end{array}$ & $\begin{array}{c}12 \\
\text { évesek } \\
2003\end{array}$ & $\begin{array}{c}13 \\
\text { évesek } \\
2002\end{array}$ & $\begin{array}{c}14 \\
\text { évesek } \\
2001\end{array}$ & $\begin{array}{c}15 \\
\text { évesek } \\
2000\end{array}$ & $\begin{array}{c}\text { Nem } \\
\text { válaszolt }\end{array}$ & Összesen \\
\hline Fiú & 129 & 177 & 167 & 127 & 15 & 5 & 17 & 638 \\
\hline Lány & 149 & 172 & 150 & 113 & 17 & 0 & 17 & 618 \\
\hline Összesen & 286 & 373 & 341 & 242 & 32 & 8 & 38 & 1256 \\
\hline
\end{tabular}

A gyermekek szociokulturális hátterének jellemzésére a szülők legmagasabb iskolai végzettségét a pedagógiai kutatásokban fontos mutatóként alkalmazzák (Csapó, 2002), ezért megvizsgáltuk a mintát ebböl a szempontból is. A 6. és 7. ábrán az anya és az apa legmagasabb iskolai végzettségének eloszlását ábrázoltuk. Különösen 4. évfolyamon magas azoknak a tanulóknak az aránya, akik nem tudtak információt adni erről (6. és 7. ábra 8. oszlopai; az összes kategóriát a 4. sz. melléklet tartalmazza). Összességében a vizuális kommunikációs képességet mérő tesztet kitöltők negyede a „nem tudom” választ adta vagy nem töltötte ki a kérdőívnek ezt a részét, ezért az erre vonatkozó adataink hiányosak. Mivel a vizuális képességek fejlődése korábbi kutatások alapján nem mutat kapcsolatot a szülök iskolai végzettségével és egyéb szociokulturális háttér változókkal sem, (pl. Kárpáti és Gyebnár, 2013, Kárpáti és Gaul, 2011).

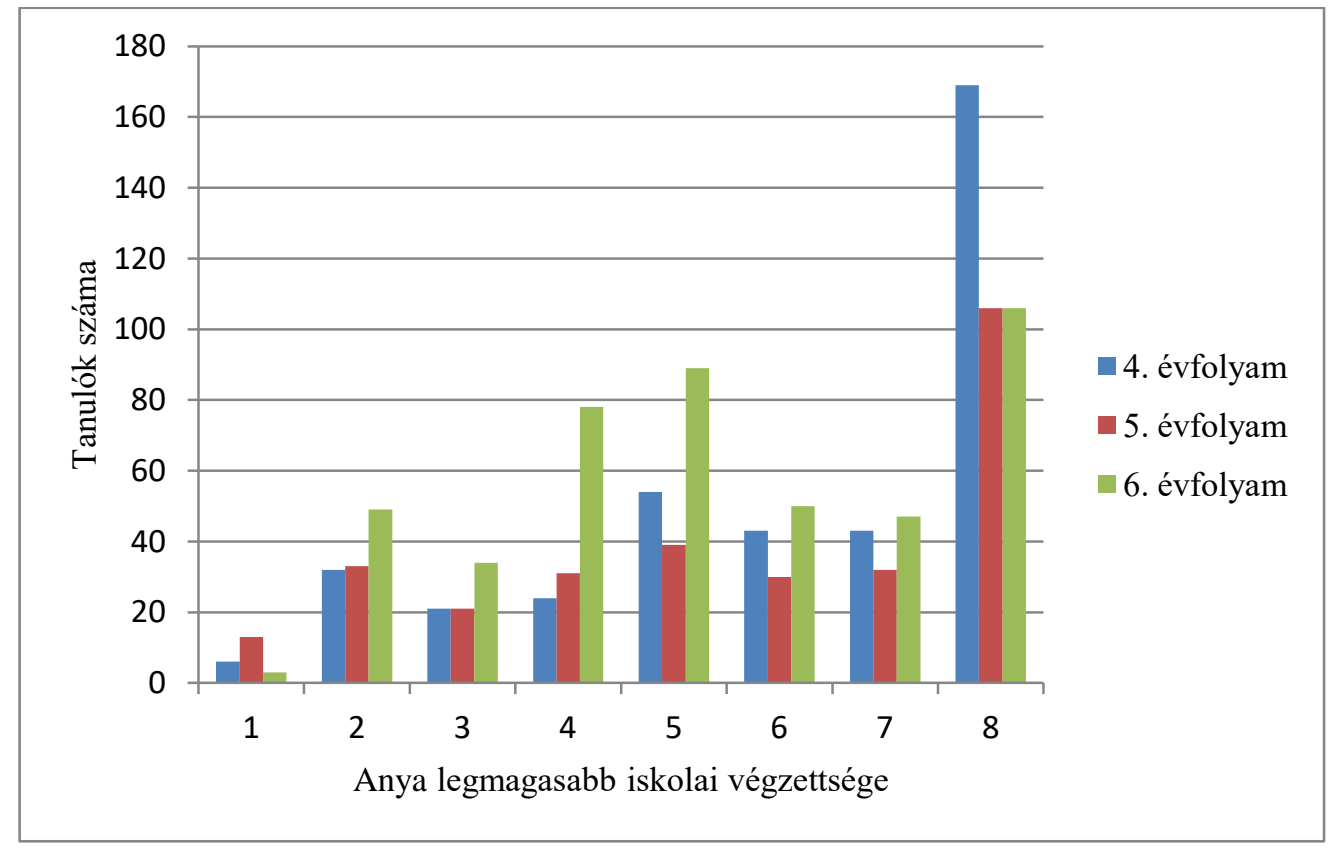

6. ábra Anya legmagasabb iskolai végzettségének évfolyamonkénti eloszlása 


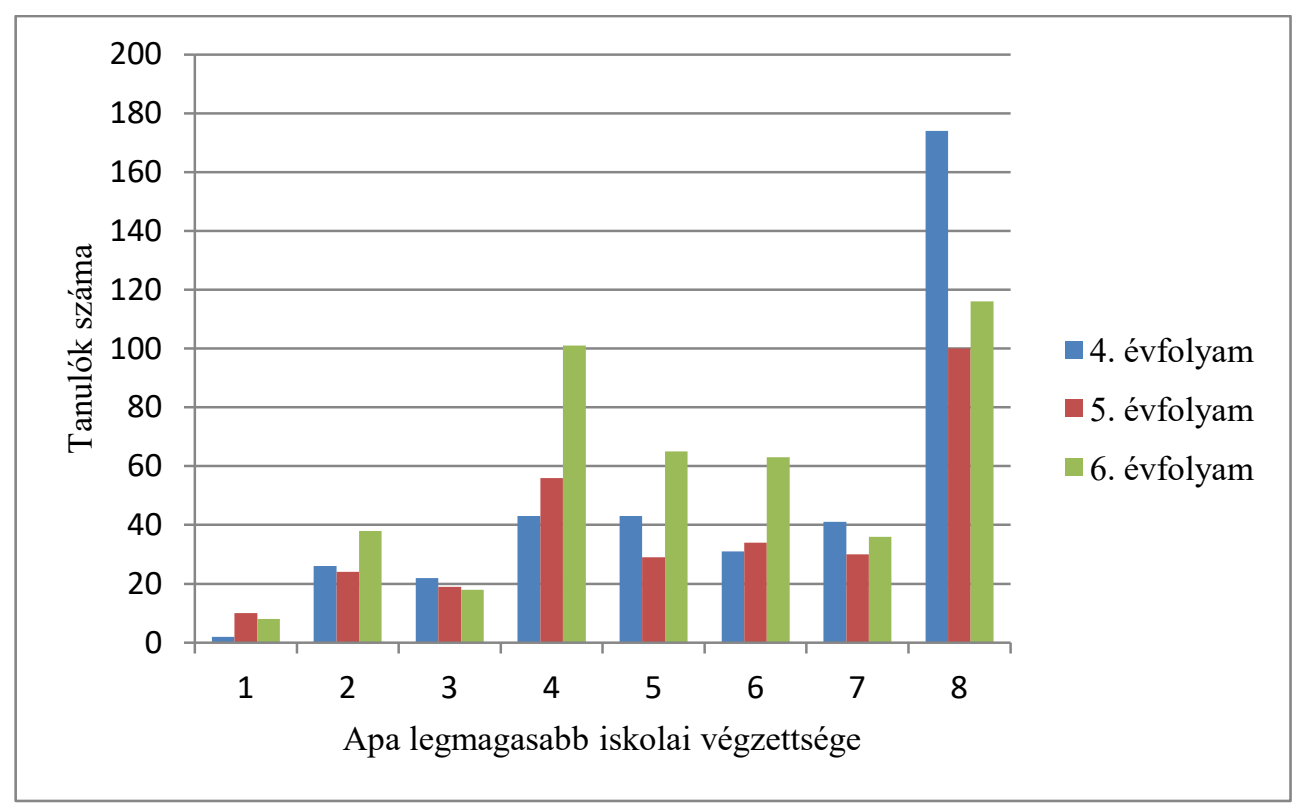

7. ábra Apa legmagasabb iskolai végzettségének évfolyamonkénti eloszlása

\subsection{A kutatás taxonómiája}

Kiindulópontunk a 2009-2011-ben zajlott vizuális képességek értékelését célul kitüző TÁMOP kutatás ${ }^{23}$ során kialakított framework jellegü képességstruktúra volt, melyet a 6.1 . fejezetben ismertettünk. Az akkori kutatásban integrált, alkotói és befogadói feladatokat fejlesztettek a 4. táblázatban található képességek értékelésére. Ezt mintegy 7000 fős mintán validálták. Kiválogattuk azokat a részképességeket, melyek a vizuális kommunikációhoz tartoznak, melyek megfelelnek a befogadás kritériumnak, hiszen jelen kutatásban a vizuális kommunikációs képesség befogadó aspektusát vizsgáljuk. A szükítés és néhány képességfogalom módosítása után újabb mérési szakasz kezdődött (6.2. fejezet pilot), melynek során ismét módosítottunk a képességrendszeren. Míg az első két mérés során nem jelentek meg a képességszintek, az új, vizuális kommunikációs képesség részképességeit szintekre bontottuk és a szintek szerint határoztuk meg az egyes képességeket. Igy négy részképesség alkotja a vizuális kommunikációs képességet: komponálás síkban, absztrakció, szimbolizáció és modalitásváltás.

A részképességeket három műveleti szinten értelmezzük: vizuális felismerés, vizuális értelmezés és vizuális elemzés. Ezek a szintek a vizuális nevelés módszertani dokumentumai és tantervei szerint egymásra épülnek és egy nagy mintás müelemző képesség vizsgálatban is jól elkülöníthető fejlettségi szinteknek bizonyulta. (Kárpáti, 1992a). Minden szintet értelmezzük a befogadás és az alkotás aspektusából egyaránt. A vizuális kommunikációs képesség részképességeit tartalmazó, a kutatás során alkalmazott taxonómiát a 15. táblázatban közöljük. A vizuális képességek online mérésére kidolgozott mérőeszközök ennek a rendszernek (15. táblázat) a befogadás aspektusára épülnek. A taxonómia fejlesztését a 14. táblázatban összegeztük, a folyamat nyomon követésének megkönnyítése érdekében. Minden változtatás empirikus tapasztalatokra épít, mely mérési szakaszokat ebben a táblázatban szintén összefoglaltuk. Jól látható, hogy nem csak kiemeltünk egy-egy részképességeket, hanem át is értelmeztünk, illetve összevontunk részképességeket megszüntetve a redundanciát, illetve új szintek kerültek be a folyamat során a taxonómiába.

${ }^{23}$ Diagnosztikus mérések fejlesztése (2009-2015) TÁMOP-3.1.9-08/1-2009-0001 (1. fázis) és a TÁMOP3.1.9-11/1-2012-0001 (2. fázis) 
14. táblázat Az egyes mérési szakaszok taxonómiáinak és a taxonómiát alkalmazó mérések összegzése

\begin{tabular}{|c|c|c|}
\hline $\begin{array}{l}\text { 2009-2011 első kutatási } \\
\text { szakasz: a vizuális képesség } \\
\text { részképességet tartalmazó } \\
\text { taxonómia }\end{array}$ & $\begin{array}{l}\text { 2012-2015. második kutatási } \\
\text { szakasz: a vizuális } \\
\text { kommunikációs képesség } \\
\text { részképességeit pilot } \\
\text { mérésének taxonómiája }\end{array}$ & $\begin{array}{l}\text { 2012-2015. második } \\
\text { kutatási szakasz: A } \\
\text { vizuális kommunikációs } \\
\text { képesség nagymintás } \\
\text { mérésének taxonómiája }\end{array}$ \\
\hline Megfigyelés & Felismerés & \\
\hline $\begin{array}{l}\text { Látványfelismerés és } \\
\text { értelmezés }\end{array}$ & Értelmezés & \\
\hline $\begin{array}{l}\text { Vizuális emlékezet } \\
\text { (tapasztalatok látványok } \\
\text { előhívása) }\end{array}$ & Leképezés & \\
\hline Vizuális elemzés & Vizuális elemzés & \\
\hline $\begin{array}{l}\text { Formaalkotás a síkban (2D) } \\
\text { és térben (3D) }\end{array}$ & & \\
\hline Manipulációk & & \\
\hline $\begin{array}{l}\text { Rekonstrukciós } \\
\text { (transzponáló) képesség }\end{array}$ & & \\
\hline Absztrakció & Absztrakció, elvonatkoztatás & $\begin{array}{l}\text { Absztrakció (vizuális } \\
\text { felismerés, vizuális } \\
\text { értelmezés és vizuális } \\
\text { elemzés szinten) }\end{array}$ \\
\hline Szimbólumképzés & Szimbolizáció & $\begin{array}{l}\text { Szimbolizáció (vizuális } \\
\text { felismerés, vizuális } \\
\text { értelmezés és vizuális } \\
\text { elemzés szinten) }\end{array}$ \\
\hline \multicolumn{3}{|l|}{$\begin{array}{l}\text { Ábrák alkotása } \\
\text { és értelmezés }\end{array}$} \\
\hline \multicolumn{3}{|l|}{$\begin{array}{l}\text { Nem vizuális jellegü } \\
\text { információk megjelenítése }\end{array}$} \\
\hline \multicolumn{3}{|l|}{$\begin{array}{l}\text { Időbeli folyamatok } \\
\text { megjelenítése }\end{array}$} \\
\hline Modalitásváltás & Modalitásváltás & $\begin{array}{l}\text { Modalitásváltás (vizuális } \\
\text { felismerés, vizuális } \\
\text { értelmezés és vizuális } \\
\text { elemzés szinten) }\end{array}$ \\
\hline Képalkotás, komponálás & Komponálás síkban és térben & $\begin{array}{l}\text { Komponálás síkban } \\
\text { (vizuális felismerés, } \\
\text { vizuális értelmezés és } \\
\text { vizuális elemzés szinten) }\end{array}$ \\
\hline \multicolumn{3}{|l|}{ Téralakítás } \\
\hline \multicolumn{3}{|l|}{ Konstruálás } \\
\hline \multicolumn{3}{|l|}{$\begin{array}{l}\text { A síkbeli és térbeli } \\
\text { vizuális megjelenítő, kifejező } \\
\text { eszközök adekvát használata }\end{array}$} \\
\hline \multicolumn{3}{|l|}{ Kreativitás } \\
\hline Anyagalakítás, & & \\
\hline
\end{tabular}


2010-2011. papíralapú nagymintás alkotói és befogadói részképességeket mérő feladatok adatfelvétele (6.1. fejezet)
2013. papíralapú és online vizuális kommunikációs képesség befogadói részképességeket mérő teszt pilot mérése (6.2. fejezet)
2015. nagymintás vizuális kommunikációs képesség befogadói részképességeket mérö teszt adatfelvétele ( 7 . fejezet)

15. táblázat A vizuális kommunikációs képesség részképességeinek rendszere

Képességszint Részképesség

\section{Szint meghatározása}

\section{ALKOTÁS}

BEFOGADÁS
Elkülöníti a vizuális jeleket (pl. pont, vonal, folt, tónus, szín, forma), és előzetes terv nélkül állítja össze a kompozíciót.

Használja a vizuális jeleket mintakövetéssel.

A vizuális jelek (pont, vonal, folt, szín, forma) egy részét összerendezi, de az egész képet nem rendezi harmonikus egységgé.

A vizuális jeleket részben önállóan, részben mintakövetéssel használja.

Vizuális elemzés Komponálás síkban 3.

Adott képmezőben koherens ábrázolást, tervezett vizuális kompozíciót készít. Tudatosan alkalmazza a kiemelés, képelemek szervezése, a figyelemirányítás és figyelemvezetés képnyelvi módszereit.
Felismeri a vizuális jeleket ( $\mathrm{pl}$. pont, vonal, tónus, folt, szín, forma), de ezek kapcsolatait nem köti élményhez vagy tartalomhoz. Ismert kontextusban megjelenő vizuális jelek jelentését felismeri.

Egyszerü vizuális jelek, jelcsoportok (kompozíciók) jelentését értelmezi ismert és új kontextusban is.
Összetett vizuális jeleket, jelcsoportokat (kompozíciókat) elemez formai-tartalmi szempontból. A képelemek közötti összefüggéseket, a figyelemirányítás, a figyelemvezetés képi megjelenítését a tartalommal, üzenettel kapcsolatban elemzi. A vizuális jelek elemzésére új kontextusban is képes.

Elkülöníti és felismeri a jeleket, jelcsoportokat, felismeri a lényegkiemelés, egyszerüsítés (redukció) képnyelvi eszközeit. alkot jeleket, formákat (pétd térkép, útvonalrajz, magyarázó ábrák, folyamatábrák, vizuális alapelemek). Tudatosan alkalmazza a lényegkiemelés, egyszerüsítés (redukálás) 


\begin{tabular}{|c|c|c|}
\hline Vizuális értelmezés & Absztrakció 2. & $\begin{array}{l}\text { Képes ábrázolási konvenciókon } \\
\text { alapuló, szabályokhoz igazodó, } \\
\text { jelentést hordozó közlő és } \\
\text { magyarázó rajzok (szerelési } \\
\text { ábrák, folyamatábrák) } \\
\text { létrehozására. Valós vagy } \\
\text { elképzelt információkat, adatokat, } \\
\text { összefüggéseket, fogalmakat, } \\
\text { struktúrákat érthetően megjelenít. } \\
\text { Képes folyamatok, } \\
\text { állapotváltozások, mozgásfázisok } \\
\text { megjelenítésére is. }\end{array}$ \\
\hline
\end{tabular}

Vizuális elemzés Absztrakció 3.
A jeleket és jelcsoportokat tudatosan, tervezetten használja, egyszerüsített ábrák, képi jelek, struktúrák és összefüggések megjelenítésére is képes.
Értelmezi a valóság és az elemi vizuális jelek közötti kapcsolatokat. Konvenciókon alapuló, szabályokhoz igazodó, jelentést hordozó közlő és magyarázó rajzokat, ábrázolásokat (szerelési ábrák, folyamatábrák, adatok, összefüggések, fogalmak, struktúrák képi megjelenítése, valós vagy elképzelt viszonyok, állapotok változásainak, mozgásfázisok ábrái) értelmez.

Ismeri és alkalmazza a forma és funkcióelemzés módszereit. Egyszerü ábrák, képi jelek, jelcsoportok, struktúrák és összefüggések, valamint műalkotások elemzésére képes.

\begin{tabular}{|c|c|c|c|}
\hline Vizuális felismerés & Szimbolizáció 1. & $\begin{array}{l}\text { Előzetes terv nélkül képes } \\
\text { elemek, jelképek, allegóriák, } \\
\text { vizuális metaforák képzésére, } \\
\text { ismert kontextusban való } \\
\text { ábrázolására. }\end{array}$ & $\begin{array}{l}\text { Ismert kontextusban } \\
\text { megjelenő jelképek, } \\
\text { allegóriák, vizuális metaforák } \\
\text { felismerésére meghatározására } \\
\text { és megnevezésére képes. }\end{array}$ \\
\hline Vizuális értelmezés & Szimbolizáció 2. & $\begin{array}{l}\text { Tervezetten ábrázol részben } \\
\text { ismert kontexusban jeleket, } \\
\text { jelképeket, allegóriákat, vizuális } \\
\text { metaforákat. }\end{array}$ & $\begin{array}{l}\text { Jelképek, allegóriák, vizuális } \\
\text { metaforák elkülönítésére, } \\
\text { összehasonlítására r és } \\
\text { értelmezésére képes részben } \\
\text { ismert kontextusban. }\end{array}$ \\
\hline Vizuális elemzés & Szimbolizáció 3. & $\begin{array}{l}\text { Képes tudatos, tervezett jel, } \\
\text { jelkép, allegória és } \\
\text { metaforahasználatra, elvont } \\
\text { fogalmak megjelenítésére, } \\
\text { ábrázolására új kontextusban is. }\end{array}$ & $\begin{array}{l}\text { Jelképet, allegóriákat és } \\
\text { metaforákat, elvont } \\
\text { fogalmakat elemez, értékel, a } \\
\text { vizuális jeleket új } \\
\text { kontextusban elemzi. }\end{array}$ \\
\hline Vizuális felismerés & Modalitásváltás 1 . & $\begin{array}{l}\text { Különböző észlelési } \\
\text { tapasztalatokat, modalitásokat } \\
\text { (látás, hallás, tapintás, szaglás, } \\
\text { ízlelés) előzetes terv nélkül képes } \\
\text { vizuális rendszerben rögzíteni, } \\
\text { mintakövetéssel vizuális jellé } \\
\text { alakítani. }\end{array}$ & $\begin{array}{l}\text { Különböző észlelési } \\
\text { tapasztalatok, modalitások } \\
\text { (látás, hallás, tapintás, szaglás, } \\
\text { ízlelés) vizuális rendszerben } \\
\text { való megjelenítését felismeri, } \\
\text { valamint ismert vizuális } \\
\text { jeleket képes más } \\
\text { modalitásokhoz kapcsolni. }\end{array}$ \\
\hline Vizuális értelmezés & Modalitásváltás 2. & $\begin{array}{l}\text { Különböző észlelési } \\
\text { tapasztalatokat, modalitásokat } \\
\text { (látás, hallás, tapintás, szaglás, } \\
\text { ízlelés) előzetes terv alapján } \\
\text { képes vizuális rendszerben } \\
\text { rögzíteni, valamint részben } \\
\text { mintakövetéssel vizuális jellé } \\
\text { alakítani. }\end{array}$ & $\begin{array}{l}\text { Különböző észlelési } \\
\text { tapasztalatok, modalitások } \\
\text { (látás, hallás, tapintás, szaglás, } \\
\text { ízlelés) vizuális rendszerben } \\
\text { való megjelenítését értelmezi, } \\
\text { valamint ismert és részben új } \\
\text { vizuális jeleket képes más } \\
\text { modalitásokhoz kapcsolni. }\end{array}$ \\
\hline
\end{tabular}


Különböző észlelési tapasztalatok, modalitások (látás, hallás, tapintás, szaglás, ízlelés) tervezetten képes vizuális rendszerben rögzíteni, valamint önálló alkalmazásban, új kontextusban képes vizuális jellé alakítani, új ábrázolásokat létrehozni.
Különböző észlelési tapasztalatok, modalitások (látás, hallás, tapintás, szaglás, ízlelés) vizuális rendszerben való megjelenítését elemzi, valamint új vizuális jeleket képes más modalitásokhoz kapcsolni.

\subsection{A kutatásban alkalmazott mérőeszközök bemutatása, a háttérváltozók leírása}

\subsubsection{A vizuális kommunikációs képességet mérő tesztek feladatai}

A három évfolyam tesztjei összesen 119 itemet tartalmaznak, melyeket a vizuális kommunikációs képesség részképességeihez rendeltünk hozzá (2. melléklet). Az itemek számát a 16. táblázatban összegeztük.

16. táblázat A tesztek itemei a vizuális kommunikációs képesség részképességeihez, szintenként, évfolyamonként

\begin{tabular}{lccccccccccccc}
\hline & \multicolumn{3}{c}{$\begin{array}{c}\text { Komponálás } \\
\text { síkban }\end{array}$} & \multicolumn{3}{c}{ Absztrakció } & \multicolumn{3}{c}{ Szimbolizáció } & \multicolumn{3}{c}{ Modalitásváltás } \\
\hline Évfolyam & 4 & 5. & 6. & 4. & 5. & 6. & 4. & 5. & 6. & 4. & 5. & 6. \\
Felismerés & 7 & 1 & 5 & 10 & 5 & 5 & 7 & 7 & 0 & 0 & 4 & 4 \\
Értelmezés & 4 & 15 & 9 & 10 & 15 & 23 & 4 & 2 & 1 & 12 & 9 & 12 \\
Elemzés & 1 & 5 & 7 & 1 & 1 & 1 & 0 & 0 & 4 & 0 & 0 & 0 \\
Összegzés & 12 & 21 & 21 & 21 & 21 & 29 & 11 & 9 & 9 & 12 & 13 & 16 \\
\hline
\end{tabular}

A jelen kutatás előzményének számító papíralapú mérés feladatai közül nyolcat próbáltunk ki a pilot során, de csak négyet tartottunk meg. A papíralapú, alkotó jellegü, nyílt végü feladatok átírása nehézkes, erőltetett volt, valamint a legtöbb esetben túl hosszú szövegek alkalmazására lett volna szükség, ezért nem ragaszkodtunk a feladatok megtartásához. A megtartott feladatok egyike a 8. ábrán látható. Az eredeti feladatban nyílt végü kérdésekre válaszoltak a tanulók. A 9. ábra feladatában a korábbi mérés során készült rajzokból válogattunk. A mérés során a gyerekrajzokat több szempont szerint 5 pontos skálán értékelték, kiválasztottunk egy maximális pontszámot kapott rajzot, mint helyes megoldást és három kevésbé jó megoldást. Így négy opció közül választhattak az online felületen a feladat megoldása során. A bemutatott két feladat eredeti verziója a 3. mellékletben található. 


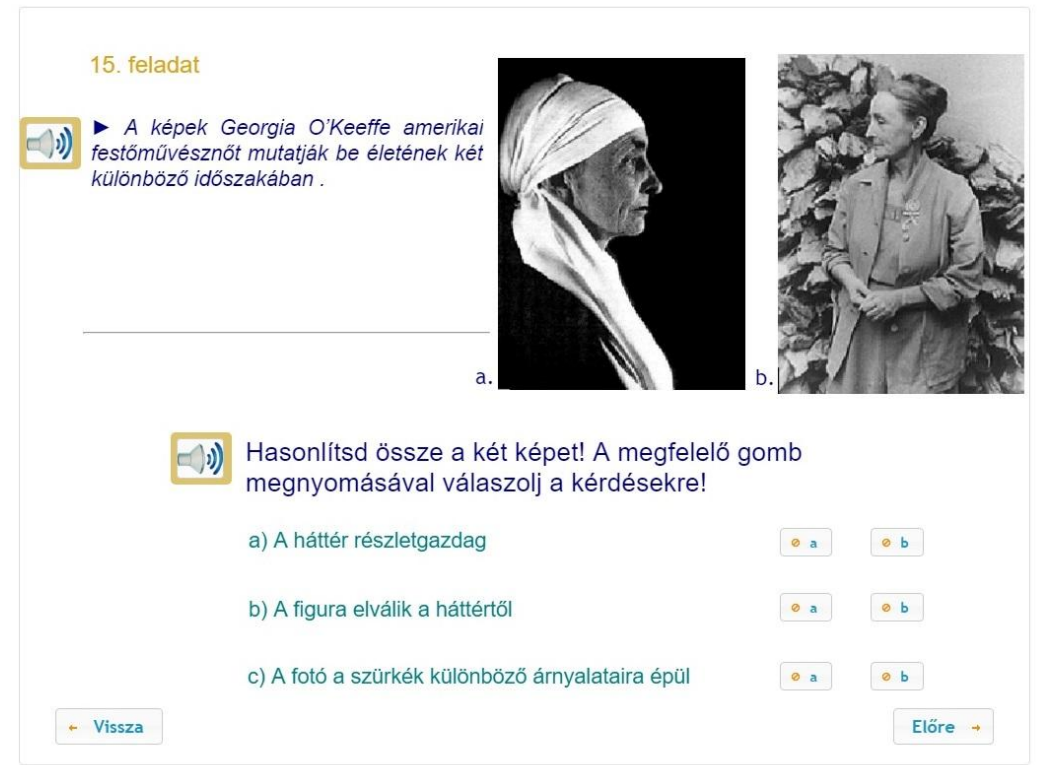

8. ábra Példafeladat papíralapú feladat online felületre való adaptációjára. 2009-11-es mérési szakasz egyik feladatának adaptációja a 6. évfolyam számára készitett tesztben. Az" okeffee" címü feladat komponálás síkban részképességhez tartozik, vizuális értelmezés képességszinten. Az eredeti feladat nyiltvégü, melynek értékelését az online platformon nem vagy csak nagyon nehézkesen tudtuk volna megoldani.

\section{7. feladat}

ग) Olvasd el az alábbi mesét, és válassz a képek közül! Melyik rajz ábrázolja legpontosabban a családi viszonyokat, a szereplők tulajdonságait? Kattints a választott képre!

A rajzokat másodikos gyerekek készitették a királyi családról. 1)) "Hol volt, hol nem volt, volt egyszer egy király és egy királyné, akiknek sorban született három fiuk. Telt-
múlt az idó, a gyerekek felnóttek és feleséget választottak maguknak. A legidősebb királyfi a Virágot Nevetö Királykisasszonyt, a középső királyfi a Világszép Nádszálkisasszonyt, míg a legkisebb királyfi az Aranyhajú Királykisasszonyt vette feleségül. A legidösebb királyfinak hamarosan született egy fia; a középsó királyfi családja szintén egy fiúgyermekkel gyarapodott, a legkisebb királyfiéknál pedig két ikerkislány született."
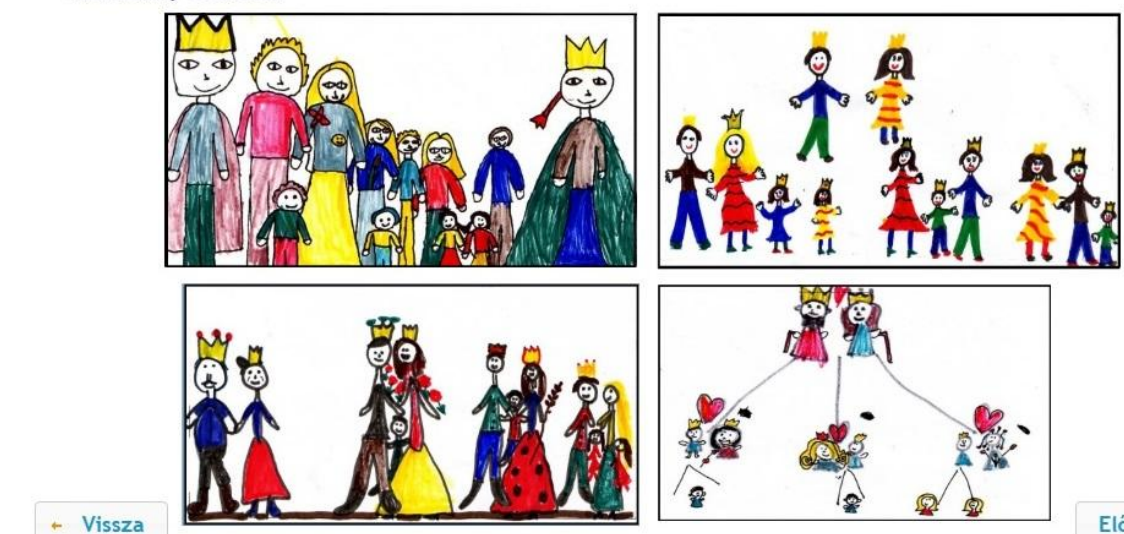

9. ábra Példafeladat papíralapú feladat online felületre való adaptációjára A 2009-11-es mérési szakasz egyik feladatának adaptációja a 4. évfolyamos tesztben. A feladat adaptálásához az elsö mérési szakaszban készült gyermekrajzokat használtuk fel. A „családfa” címü feladat a szimbolizáció képességhez tartozik, vizuális értelmezés szinten.

A legtöbb feladattípusnál több item alkalmazására volt szükség a vaktalálatok csökkentése és a megbízhatósági mutatók javítása érdekében. A feladatokat úgy állítottuk össze, hogy azok megoldhatóságát a diszciplináris tudás ne befolyásolja. Törekedtünk olyan a témaválasztásra, amely mindkét nem számára egyformán motiváló. A próbamérések során 
kiderült, hogy vannak olyan tanulók, akiknek az szövegértése nem éri el a feladatok megoldásához szükséges szintet, ezért a feladatokban hangalámondások segítik a szövegek feldolgozását. A hangfájl a feladat betöltésével automatikusan elindult, majd újra rákattintva annyiszor hallgathatták meg, ahányszor csak igényelték.

A tesztek képanyagát saját készítésű és a hétköznapi életben használt ábrák és piktogramok, saját készítésü és mesekönyvekből vett illusztrációk, képzőművészeti alkotások, saját fotók, valamint a korábbi szakaszban készült gyerekrajzok alkotják. A felhasznált vizuális minták csoportjait a 17. táblázatban közöljük. A vizuális mintákat képességszintenként ismertetjük.

17. táblázat A tesztben szereplö feladatok rendszere és vizuális minták az elsödleges képességelemek szerint

\begin{tabular}{|c|c|c|c|}
\hline Képességszintek & Vizuális minták & $\begin{array}{c}\text { Feladatok } \\
\text { száma }\end{array}$ & $\begin{array}{c}\text { Itemek } \\
\text { száma } \\
\end{array}$ \\
\hline $\begin{array}{cl}\text { Vizuális felismerés } \\
\text { - } & \text { színfelismerés } \\
\text { - } & \text { formafelismerés } \\
\text { - } & \text { képrészletek } \\
& \text { felismerése } \\
\text { - } & \text { különbözó médiumokon } \\
& \text { történt ábrázolások } \\
& \text { felismerése } \\
\end{array}$ & $\begin{array}{ll}\text { - } & \text { hétköznapi fotók } \\
\text { - } & \text { klasszikus } \\
& \text { képzőmüvészeti } \\
& \text { alkotások } \\
\text { - } & \text { szoborfotók } \\
\text { - } & \text { mesekönyv } \\
& \text { illusztrációk } \\
\text { - } & \text { fázisfotók } \\
\end{array}$ & 11 & 38 \\
\hline $\begin{array}{cl}\text { Vizuális értelmezés } \\
\text { - } \quad \text { cselekvéseket ábrázoló } \\
\text { rajzok értelmezése } \\
\text { - } \quad \text { tárgyakat ábrázoló } \\
\text { rajzok értelmezése } \\
\text { - } \quad \text { absztrakt formákat } \\
\text { ábrázoló rajzok } \\
\text { értelmezése } \\
\text { - } \quad \text { dallamvonal és vizuális } \\
\text { információ } \\
\text { megfeleltetése } \\
\text { - } \quad \text { relációk felimerése } \\
\end{array}$ & $\begin{array}{ll}\text { - } & \text { mesekönyv } \\
\text { - } & \text { illusztrációk } \\
\text { - } & \text { egyszerü vonalrajzok } \\
\text { - } & \text { képzőmüvészeti } \\
& \text { alkotások } \\
\text { - } & \text { elemi vizuális } \\
& \text { tartalmak (pont, } \\
& \text { vonal, geometriai } \\
& \text { formák, foltok) } \\
\text { - } & \text { hétköznapi } \\
& \text { piktogramok } \\
\end{array}$ & 26 & 67 \\
\hline $\begin{array}{c}\text { Vizuális elemzés } \\
-\quad \text { analízis } \\
\text { - } \quad \text { szintézis } \\
\text { - } \quad \text { analógia }\end{array}$ & $\begin{array}{ll} & \text { képzőmüvészeti } \\
& \text { alkotások } \\
\text { - } & \text { múleírások } \\
\text { - } & \text { fotók }\end{array}$ & 9 & 14 \\
\hline
\end{tabular}

A méröeszközökben megjelennek olyan itemek, melyek mindhárom évfolyam tesztjében szerepelnek. Ezek egyrészt a horgonyitem funkciót látják el (8.3. fejezet), másrészt olyan újszerü feladatok itemei, melyek müködéséről nincs előzetes ismeretünk a különböző évfolyamokon, illetve korosztályokban. A 2. melléklet táblázatában vastagon szedve jelennek meg a közös rész itemei. Amennyiben tesztként értelmezzük ezeket az itemeket, úgy ez a teszt 24 itemböl áll. A teszt reliabilitása megfelelő (Cronbach- $\alpha=0,78)$. Ezeket az elemeket elemezzük itemszinten a 8.3. fejezetben.

\subsubsection{A mérőeszköz feladatainak bemutatása részképességenként}

\section{Komponálás síkban}

A komponálás síkban képesség vizsgálatát a vizuális elemek felismerésével, értelmezésével és elemzésével végeztük. Megjelenik a színek figyelemirányító szerepe, 
színfelismerés, színkontrasztok, színárnyalatok felismerése, értelmezése és elemzése, formafelismerés és értelmezés, kompozíció (10. ábra). A képességelemhez 40 itemet rendeltünk a három évfolyamon.

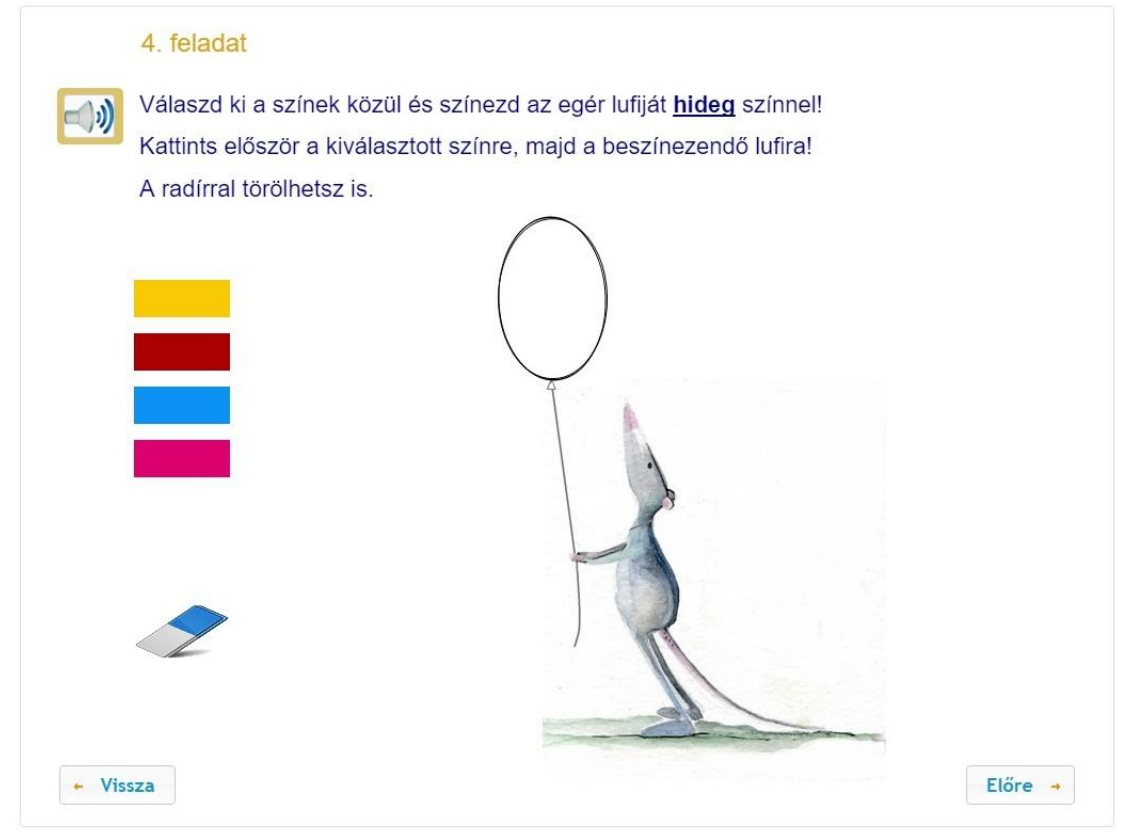

10. ábra Példafeladat a komponálás síkban részképességet mérö feladatra. A feladat vizuális felismerés szinten tartozik a részképességhez.. A feladatban szineket kell megkülönböztetni höérzet szerint.

\section{Szimbolizáció}

Jelképek, allegóriák, vizuális metaforák képzése, egy dolognak egy másik helyett való használata, tervezés, elvont szabályok alkotása tartozik a képességhez. Hétköznapi életben használt magyarázó ábrák, piktogramok, mesebeli és valós térképek értelmezése szerepel a feladatokban (11. ábra). Egy-egy szó, fogalom meghatározásához saját készítésű rajzokat használtunk fel, illetve már meglévő hétköznapi életből vett ábrákat, ábrázolásokat. A részképességhez 17 itemet készítettünk.

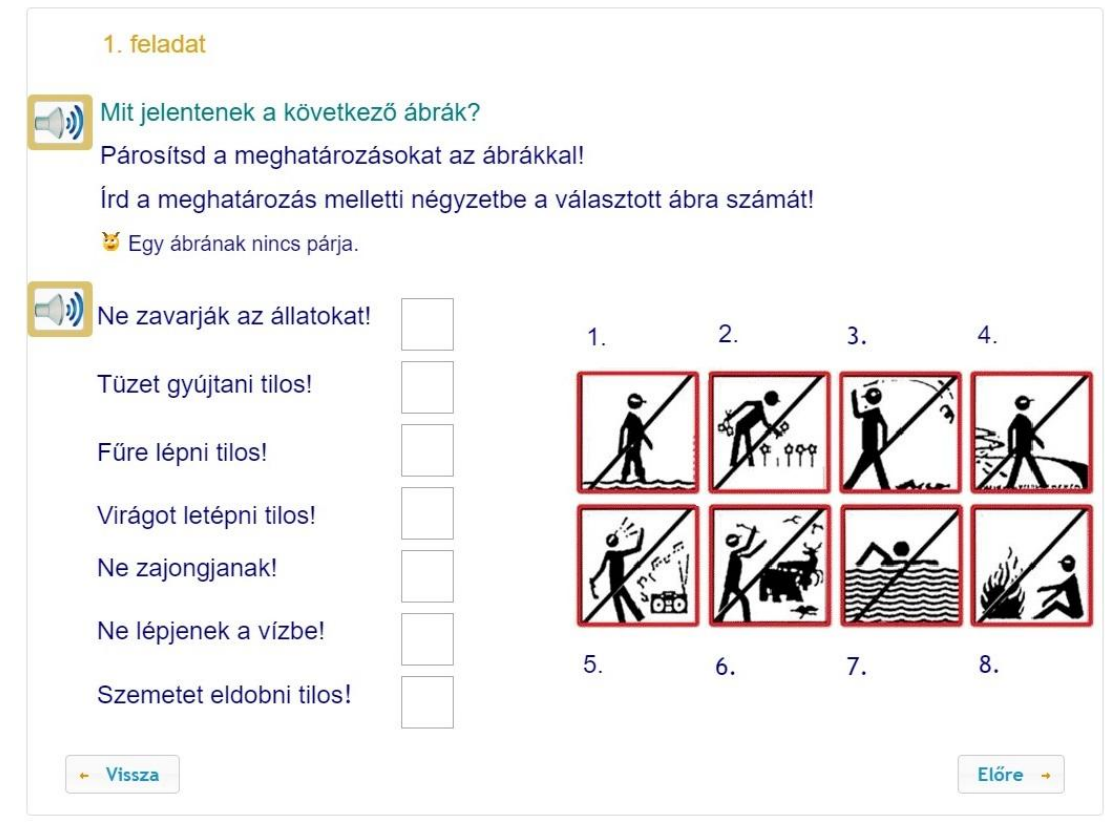

11. ábra Példafeladat a szimbolizáció részképességhez tartozó feladatra. Hétköznapi életben használt piktogramok 4., 5. évfolyamosok által megoldott feladatban vizuális felismerés szinten. 


\section{Absztrakció}

A vizuális kommunikáció részképességeként az absztrakció jelek, formák alkotása lényegkiemeléssel, egyszerüsítéssel, redukálással. Konvenciókon alapuló, szabályokhoz igazodó, jelentést hordozó jelek és képek, arányok képi megjelenítése, valós vagy elképzelt viszonyok, kapcsolatok, idő és mozgás felismerése, értelmezése és elemzése alkotja a képességhez tartozó tevékenységek körét. A tesztitemek megtervezésekor a saját készítésü rajzokhoz felhasználtuk Paul Klee: Pedagógiai vázlatkönyv a gyermekrajzokban (Klee, 1980) címü könyvének leírásait és ábrázolásait. Ezeken az ábrázolásokon gyakorta alkalmazott alapjelek (grafémák), pl. pont, hullámvonal, lépcsősen tört vonal és nyitott, többféle értelmezést lehetővé tevő alakzatok egyaránt szerepelnek (12. ábra). 36 itemet illesztettünk az absztrakció részképességhez.

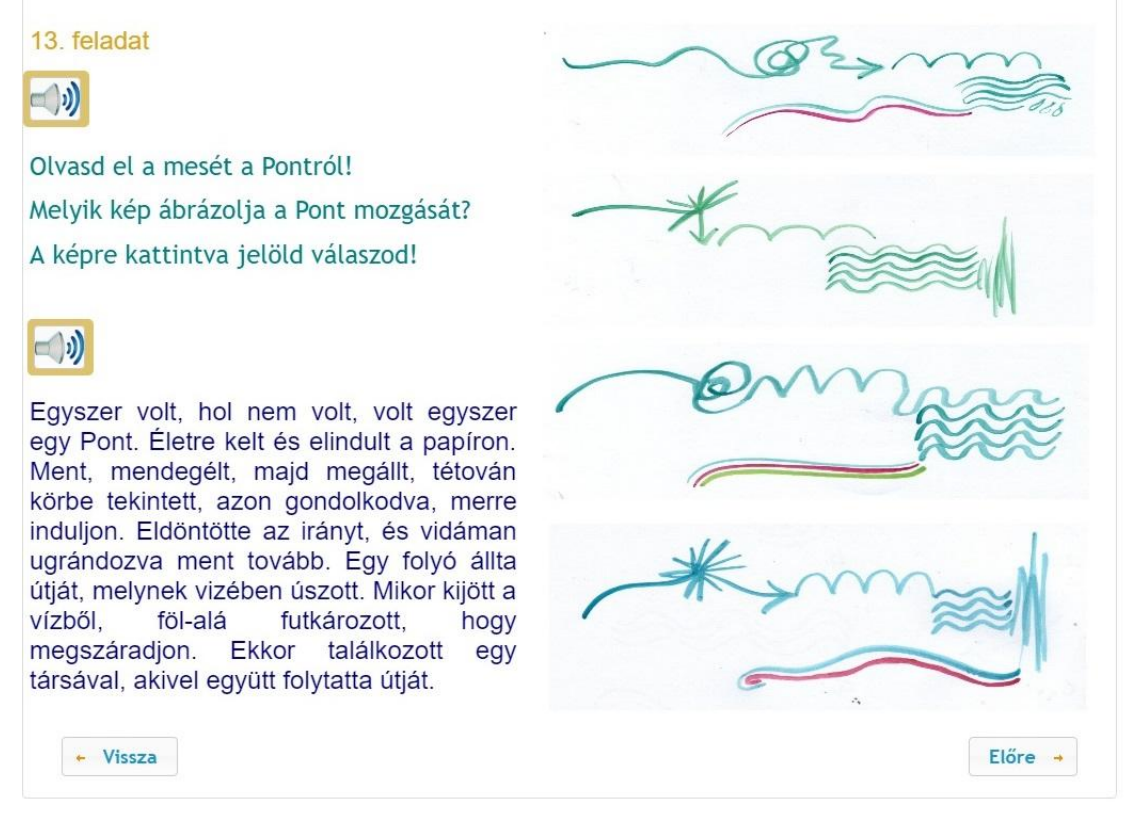

12. ábra Példafeladat a grafémákat tartalmazó feladatokra. Mindhárom évfolyam megoldotta.

\section{Modalitásváltás}

A legtöbb feladat természetszerüleg tartalmaz a szöveg-kép modalitásváltást, de vannak olyan feladatok, melyek kifejezetten ennek mérésére irányulnak. A szöveg mellett megjelenik a zenei elemek vizuális megjelenítése. A vizuális és auditív kapcsolás mérésére új feladatokat dolgoztunk ki, melyekhez hasonlók még nem szerepeltek korábbi vizuális képességtesztekben. Egyszerü ábrákat készítettünk, s az így kapott közül kell a diákoknak kiválasztaniuk azt, amely leginkább megfelel a harsonán játszott egy szólamú zenei részlet dallamvonalának (13. ábra). A modalitásváltáshoz 25 itemet rendeltünk. 

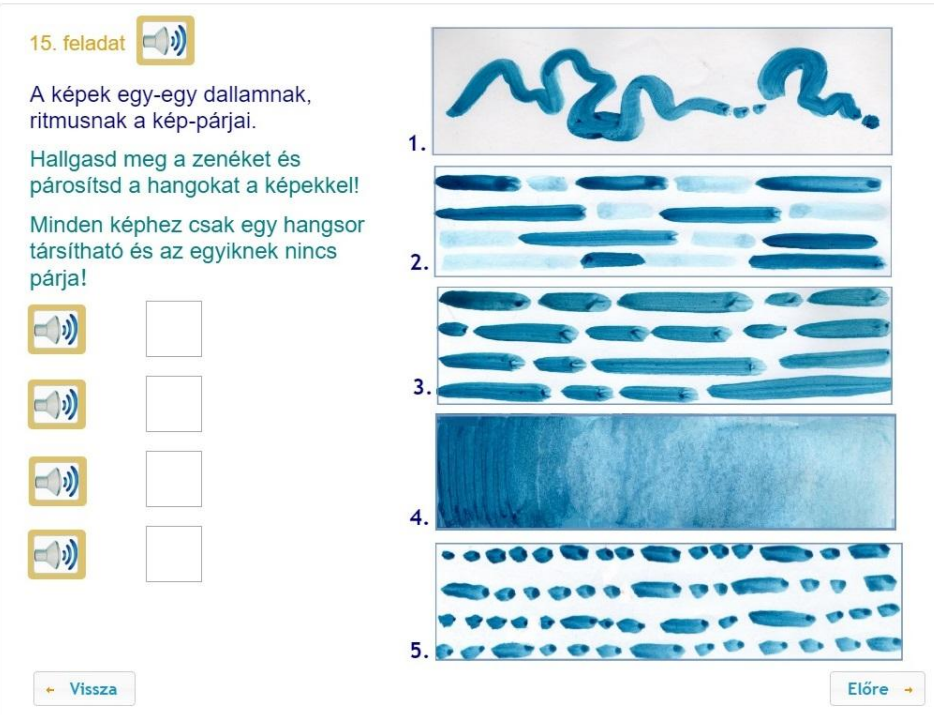

13. ábra Példafeladat a modalitásváltás képességhez tartozó feladatra A mindhárom évfolyamban megoldott vizuális és auditív modalitás értelmezésére kialakitott feladat.

\subsubsection{A mérőeszköz feladatainak bemutatása képességszintenként}

\section{Vizuális felismerés}

A vizuális kommunikáció képességrendszerében a felismerés a látottak lényeges vonásainak azonosítása szerepel a szint meghatározásában (pl. 14. ábra). Ide soroltuk a müalkotások témájának, müfajának azonosítását is.

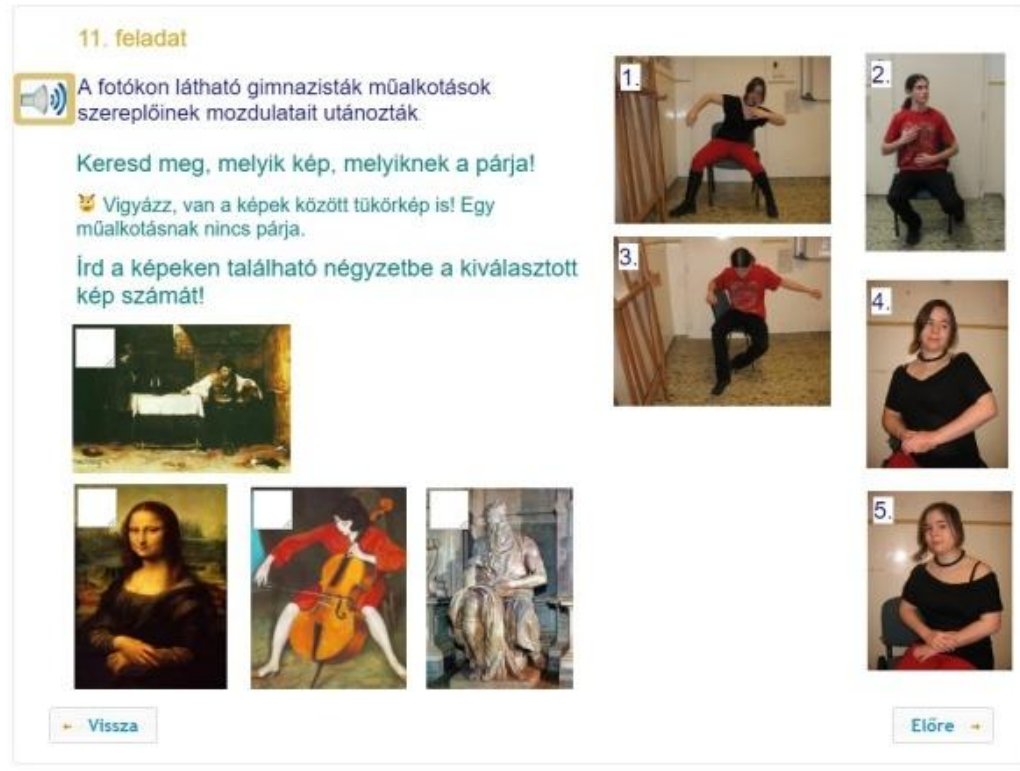

14. ábra Példafeladat a vizuális felismerés szintre. A feladat a komponálás síkban részképességhez tartozik. A feladat képein középiskolások mutatják be a müalkotások mozdulatait, melyeket a tanulóknak azonositani kell..

\section{Vizuális értelmezés}

A legtöbb müveletet és ebből következően a legtöbb feladatot tartalmazó szint a vizuális értelmezés részképességét fedi le (pl. 15. ábra). A vizuális jelek közötti kapcsolat értelmezését és megteremtését, következtetések levonását, látványok, képek, szövegek alapján, nézőpontváltás képességét jelenti. Ide tartozik a jelentést hordozó, közlő és magyarázó rajzok, ábrák, olvasása, adatok, összefüggések, fogalmak, struktúrák, arányok értelmezése (pl. 
grafikon, használati utasítás) is. Vizuális értelmezés szintén a valós vagy elképzelt viszonyok, állapotok változásainak, mozgásfázisok, vizuális dinamika, kapcsolatok megjelenítésének értelmezése.

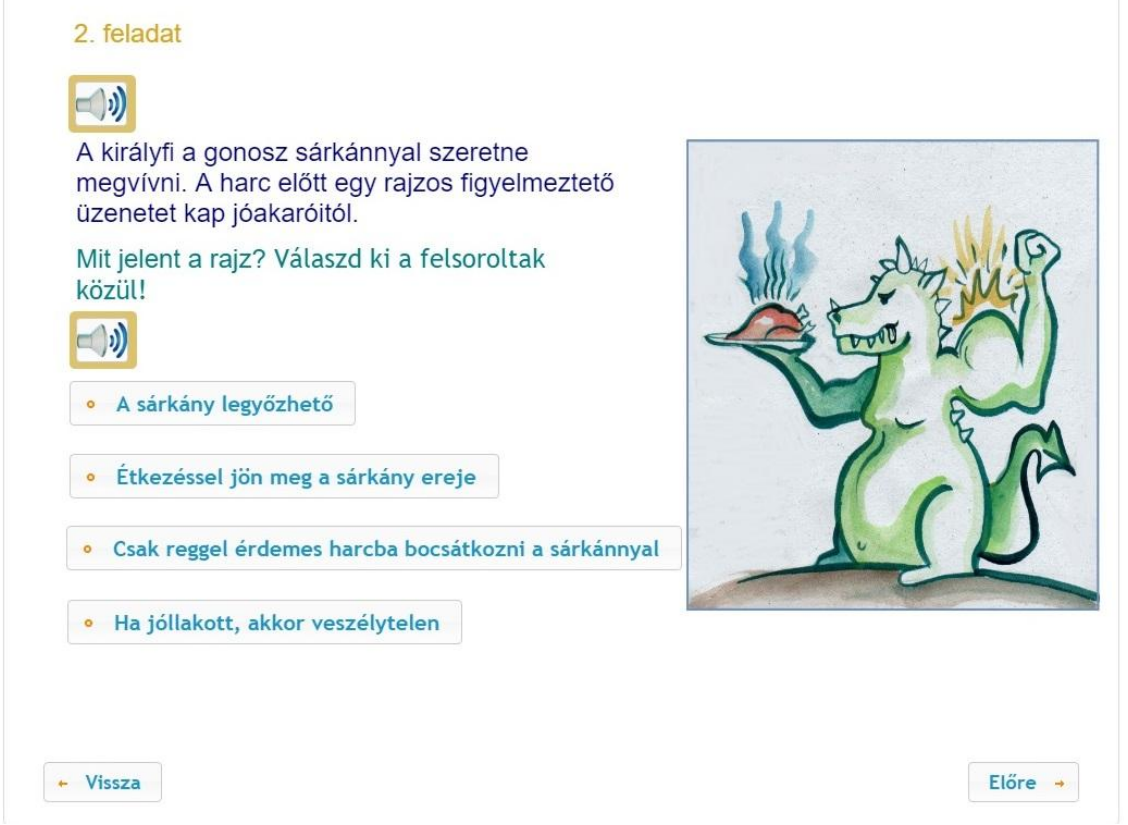

15. ábra Példafeladat a vizuális értelmezés szinthez a 4. évfolyamos tesztben.

\section{Vizuális elemzés}

A vizuális elemzés analitikus és szintetikus müveleteket tartalmaz. Vizuális elemzés során azonosítjuk a jelentést, ha nem egyértelmüek az információk, ellentmondások vannak a vizuális mintában, a konfigurációk nehezen azonosíthatók stb. A történeti és stíluselemzés, valamint a forma-és kompozícióelemzés képi eszközökkel, analógiák felismerése és csoportosítása, a képi információk rendszerezése szintén a vizuális elemzés részei. A bemutatott példafeladatban (16. ábra) szöveg magyarázza a képet, melynek alapján kell kiválasztani a leírásnak megfelelőt. A feladat nehéz, mert megoldásához olyan stratégiát kell választani és ismerni, mely alkalmas a szöveg és kép párhuzamos értelmezésére. A sikertelen megoldások esetén nem tudjuk, hogy a kudarcot a stratégia hiánya okozza, vagy az, hogy nem ismeri fel a tanuló a képi jeleket. Ez további kutatások tárgyát képezheti, hiszen fontos eredményeket hozhat az olvasáskutatás számára is. Azok a feladatok, melyek hasonlóak, de a tanulóknak pontosan tagolt szöveg alapján kell választaniuk, könnyebbeknek bizonyultak. 


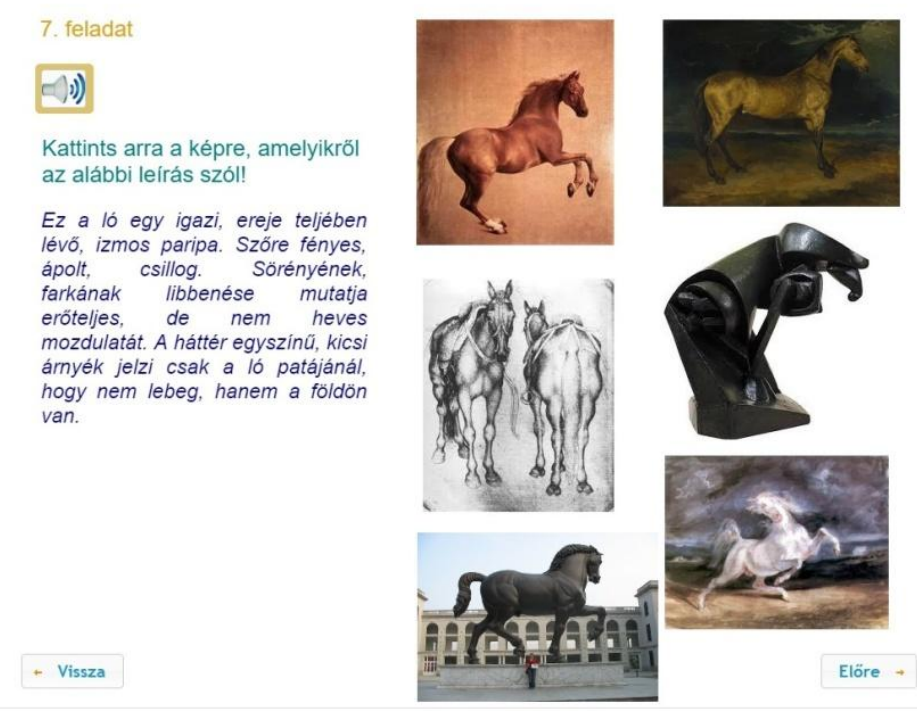

16. ábra Példafeladat a vizuális elemzés szinten mérö feladatra a 6. évfolyamos tesztben. A feladatban folyószöveg írja le a képet, melynek alapján kell kiválasztani a leirásnak megfelelöt.

\subsubsection{A háttérváltozók leírása}

A vizuális kommunikáció teszten elért eredmények mellett számos olyan adattal is rendelkezünk, amivel árnyalhatjuk, valamint részletesebben vizsgálhatjuk eredményeinket. A háttérváltozók összegzése a 18. táblázatban tekinthető át (4. melléklet). Azt a kérdöívet, illetve annak részleteit használtuk, mely a Diagnosztikus mérések fejlesztése (2009-2015) projekt több kutatásában szerepelt (Asztalos, 2016, Pásztor, 2016). A háttérváltozókra vonatkozó kérdések megválaszolására is a tesztek kitöltésekor, a tanóra keretein belül került sor. Az általános háttérváltozók (nemek aránya, születési év, évfolyam, osztály) mellett rendelkezünk adatokkal a társadalmi háttérről. A szülök iskolai végzettsége az egyik legfontosabb indikátora a gyerekek társadalmi hátterében megjelenő különbségeknek (Csapó, 2002a, 2002b). A vizuális képességek fejlődésében azonban korábbi kutatások nem támasztották alá a szülők iskolázottságának szerepét a vizuális képességek fejlődésében.

A család szokásait a következő kijelentéssel vizsgáltuk: „Milyen gyakran történnek meg a következő dolgok a te családodban?" A kérdést hét lehetőség esetében tettük fel. Ezen kívül kiegészítettük a kérdőívet úgy, hogy legyenek információink a család és a tanulók olvasási szokásairól, a tanulók internetezési és számítógép használati szokásairól is. Ez utóbbiról azért gyüjtöttünk adatokat, mert nincsenek még empirikus adataink arról, hogy milyen kapcsolatban áll ebben a korosztályban a digitális eszközök felhasználásának gyakorlata és a vizuális képesség fejlettsége. Ugyanakkor a vizuális képességek vizsgálata része az IKT müveltség kutatásának (UNESCO Digital Literacy Policy Brief, 2011), hiszen az informatikai írástudáshoz számos vizuális képességelem szükséges, mint például térszemlélet, színérzékelés, szimbolizáció. Emellett egyre inkább elterjedtek a számítógéppel segített módszerek az oktatásban (Kindler és Darras, 1997), mely szintén a kérdés vizsgálatának relevanciáját támasztja alá.

Háttérváltozók között szerepelnek a tanulók tantárgyi osztályzatai. Hazai kutatások bizonyítják, hogy a tantárgyi osztályzatok több területtel is mutatnak összefüggést, például az attitüddel, a családi szociális háttérrel, a szülők iskolai végzettségével (Csapó, 2002a). Mivel az osztályzatnak több tanulási tényezőre is hatása lehet, így indokoltnak tartottuk háttérváltozóként fölvenni a vizsgálatunkba az osztályzatot. A tantárgyi attitűdökről Csapó Benő attitűd kérdőívét használtuk (Csapó, 2002a). A tantárgyi attitüdöket a következő kérdés feltevésével vizsgáltuk: „Mennyire szereted a következő tantárgyakat? A válaszokat minden tantárgyhoz kötődően megadhatták a diákok, ötfokú skálán válaszoltak. A következő 
tantárgyak érvényesek mindhárom évfolyamon: matematika, magyar irodalom, magyar nyelv, idegen nyelv, környezetismeret/természetismeret, informatika, rajz és vizuális kultúra, énekzene, testnevelés.

Megkérdeztük a tanulókat a tanuláshoz való viszonyukról. Mivel kutatások bizonyítják, hogy a pozitív énkép és a pozitív tanulási attitüd hatással van az iskolában nyújtott teljesítményre, kíváncsiak voltunk, befolyásolja-e ez az attitüd a vizuális kommunikációs képességet mérő teszten elért teljesítményt (Józsa, 2001; Simon, 2015).

18. táblázat A háttérváltozók összegzése

\begin{tabular}{|c|c|}
\hline "Háttérváltozók & $\begin{array}{l}\text { A háttérváltozó megjelenése a } \\
\text { háttérkérdőívben }\end{array}$ \\
\hline Általános háttérváltozók & nem, születési év, évfolyam \\
\hline Iskolai eredmények & tantárgyi osztályzatok \\
\hline \multirow[t]{2}{*}{ Tantárgyi és tanulási attitüdök } & tantárgyi attitüdök \\
\hline & $\begin{array}{l}\text { iskolai eredményekkel való elégedettség } \\
\text { elérendő iskolai végzettség }\end{array}$ \\
\hline Számítógép,- és internethasználat & $\begin{array}{l}\text { számítógép használat gyakorisága, } \\
\text { mennyisége }\end{array}$ \\
\hline & internethasználat gyakorisága, mennyisége \\
\hline Szocioökonómiai változók & otthoni könyvek száma \\
\hline \multirow[t]{3}{*}{ Szociokulturális változók } & anya iskolai végzettsége \\
\hline & apa iskolai végzettsége \\
\hline & közös tevékenységek \\
\hline
\end{tabular}

\subsection{Az adatok felvételének körülményei}

A pilot mérés során képet kaphattunk arról is, hogyan a legcélszerübb szervezni az adatfelvételt, milyen akadályokba ütközhetünk, és hogyan hidalhatjuk át a felmerülö problémákat. Így az adatfelvétel a nagymintás méréskor zökkenőmentesen zajlott. A vizuális kommunikáció feladatai az eDia online felületén (ld. 7.3. fejezet) jelentek meg, így minden jelentkező intézmény elérte a teszteket. Az intézményekhez és az adott tanulóhoz központi irányítással rendeltünk azonosítókat, melyek nélkül nem lehet eljutni a tesztfelületekhez. A tesztek elérése gördülékenyen zajlott az intézményekben. A tanulók az iskola számítógépes termeiben nyitották meg böngészőből a teszteket és a hozzájuk rendelt azonosítóval kezdték meg kitöltését. A tesztek elején a tanulók néhány háttérinformációt tartalmazó kérdésre válaszoltak. A kérdések megválaszolásával egyrészt a tanulók megszokták a felületet, másrészt számunkra is szolgáltatott közvetett és közvetlen információt az adott diák számítógép használat jártasságáról (kérdésekben eltöltött idő és direkt válaszok). A diákok mindegyike használt fülhallgatót. Erre két okból volt szükség. A tesztekben szerepelnek olyan itemek, melyeket e nélkül az eszköz nélkül nem tudtak volna megcsinálni, valamint a könnyebb megértés és az olvasási nehézségek leküldése érdekében az instrukciókat nem csak elolvashatták a képernyőn, hanem meg is hallgathatták. A feladatok szövegét többször meghallgathatták és megállíthatták. A fülhallgató az iskolai számítógépes termeknek nem tartozéka, ezért ez olykor okozott fennakadást. A teszt kitöltését a kognitív és szocioökonómiai háttérváltozókra vonatkozó kérdéssort tartalmazó kérdőív követte. A tanulók a tesztet és a kérdöívet egy tanóra alatt töltötték ki.

\subsection{Az adatelemzés módszerei}

$\mathrm{Az}$ adatok elemzéséhez klasszikus és valószínüségi tesztelmélet módszereit egyaránt alkalmaztuk. A tesztek megbízhatóságának jellemzéséhez a társadalomtudományi kutatásokban elterjedt Cronbach- $\alpha$ mutatót használjuk, valamint kiszürjük az elkülönítés 
mutató alapján a nem megfelelően müködő itemeket. T-próbát, varianciaanalízist végzünk az átlagok összehasonlításához és korrelációs vizsgálatokat és varianciaanlízist az összefüggések feltárásához (Falus és Ollé, 2008). A változók közötti összefüggések modellezéséhez, valamint a hipotetikus modell illeszkedésének ellenőrzéséhez $\mathrm{R}$ program segítségével konfirmatív faktorelemzést (CFA -Confirmatory Factor Analysis) végzünk. A konfirmatív célú faktoranalízis alkalmazásával vizsgáljuk, hogy az adataink mennyire támasztják alá az előzetesen elképzelt, kialakított modellt (7.6. fejezet), mennyire felelnek meg az adatok az adott modellnek (Raykov és Marcoulides, 2006). Az elemzés során tehát a meglévő modellt teszteljük, ezzel ellenőrizve a H3 hipotézist, mely szerint a tesztekben elkülöníthető, egymással korreláló részkonstrumok vannak.

A klasszikus tesztelmélet statisztikai számításai mellett valószínüségi tesztelmélet (IRT - item response theory) eszköztárából RASCH-modellt alkalmazzuk, melyet a ConQuest programban végzünk el és amely a dichotóm adatok elemzésére alkalmas (Molnár, 2005, 2013). A valószínűségi tesztelmélet alapja az a feltételezés, hogy a gyorsabban haladó diákok nagyobb valószínüséggel oldják meg a feladatokat, valamint a nehezebb feladatokat mindenki kisebb valószínűséggel oldja meg, mint a könnyebbeket. Az eljárás során a nyerspontszámok alapján meghatározza, hogy egy adott itemet a diákok adott képességszint mellett mekkora valószínüséggel oldanak meg. Így minden itemhez kapunk egy nehézségi indexet, és minden személyhez egy képességparamétert. Az item nehézsége attól függ, hogy milyen képességszint szükséges ahhoz, hogy $50 \%$-os valószínüséggel oldjuk meg a feladatot. A személy képességparaméterét pedig az adja meg, ahol 50 \%-os valószínüséggel old meg egy adott nehézségű itemet. Az itemek nehézsége és a képességparaméterek kölcsönös viszonyban vannak, mely lehetővé teszi, hogy a kettőt közös skálán fejezzük ki (logit skála). Így a különböző tesztekkel mért tanulók, illetve itemek összehasonlíthatóak, amennyiben a mérések során megfelelő számú közös item, ún. horgonyitem szerepel az eltérő tesztekben. Ennek megfelelően a kutatásunkban is vannak olyan feladatok, melyek megjelennek a különbözö évfolyamoknak készített tesztekben. Az eljárás során kapunk egy EAP/PV mutatót, ami alkalmas a teszt megbízhatóságának jellemzésére (a mutató a modell által megmagyarázott variancia és a teljes variancia hányadosát fejezi ki). Az interpretálása megegyezik a Cronbach- $\alpha$ esetében megszokottal.

Az adatelemzés módszereit, a mért területek és a hozzájuk kapcsolódó hipotéziseket a 19. táblázatban foglaltuk össze. Törekedtünk arra, hogy a hipotézisek vizsgálata egyértelmü legyen, ezért néhány hipotézist több eljárással is vizsgáltunk. Azokban az esetekben, amelyekben a korrelációszámítás nem vagy csak gyenge együtt járást mutatott ki, nem vizsgáltuk tovább az adatokat más eljárással. A szociális háttérváltozók részben szocioökonómiai, részben szociokulturális változók (H5 hipotézis). Nem választottuk szét őket a hipotézis megfogalmazásában, mert a kutatás fókuszában nem ez áll, de az adatelemzések között megjelenik az elkülönítés. 
19. táblázat Adatelemezés módszerek, a mért területek és a hipotézisek kapcsolata

\begin{tabular}{|c|c|c|}
\hline Statisztikai eljárás & Mért területek & Kapcsolódó \\
\hline Megbízhatósági mutató & Mérőeszközök pszichometriai jellemzői & $\overline{\mathrm{H} 1, \mathrm{H} 2}$ \\
\hline T-próba & Nemek szerinti különbségek & H6 \\
\hline \multirow[t]{5}{*}{ Variancianalízis } & Évfolyamok közötti különbségek & $\mathrm{H} 4$ \\
\hline & Korosztályok közötti különbségek & $\mathrm{H} 4$ \\
\hline & Iskolák közötti különbségek & $\mathrm{H} 2$ \\
\hline & $\begin{array}{l}\text { Szülők legmagasabb iskolai végzettsége } \\
\text { szerinti különbségek }\end{array}$ & H5 \\
\hline & $\begin{array}{l}\text { Számítógép-használat hatása az } \\
\text { eredményekre }\end{array}$ & H8 \\
\hline \multirow[t]{3}{*}{ Korreláció } & $\begin{array}{l}\text { Osztályzatok és az attitüdök kapcsolata a } \\
\text { teszteredményekkel }\end{array}$ & $\mathrm{H} 7$ \\
\hline & Szociokulturális háttérváltozók & H5 \\
\hline & $\begin{array}{l}\text { Nemek és részképességek közötti } \\
\text { kapcsolat }\end{array}$ & H6 \\
\hline Konfirmatív faktorelemzés & Modellilleszkedés & H3 \\
\hline
\end{tabular}

\subsection{A teszt müködésére vonatkozó eredmények}

7.6.1 A vizuális kommunikációs képesség teszt pszichometriai jellemzői 4. évfolyamban

A vizuális kommunikációs képességet mérő teszt itemei két képességszinten négy képességhez tartoznak. A vizuális elemzést negyedik évfolyamban igazodva a kerettantervi követelményszinthez nem értelmezzük külön. A 20. táblázatban látható, hogy egy item mégis található ezen a szinten, mely item egy feladathoz tartozik és mindhárom évfolyam megoldotta. A feladatot indokoltnak láttuk benne hagyni a negyedik évfolyamos tesztben, mert ez a feladat egy másik feladat (pontmozgasa3_456) (1. melléklet) folytatása. Mivel a vizuális kommunikációs képesség mérésének nincsenek hasonló előzményei, ezért kísérleti kezdeményezésnek szántuk olyan feladat alkalmazását is, mely összetett vizuális jelek elemzését kívánja. Ugyanakkor kíváncsiak voltunk, felfedezhetö-e különbség az évfolyamok között a két feladattípus megoldása során. A feladatot külön is elemezzük a 8.3.1. fejezetben.

20. táblázat Feladatok a vizuális képességcsoport részképességeihez, szintenként 4. évfolyamon

\begin{tabular}{|c|c|c|c|c|}
\hline $\begin{array}{l}\text { Részképességek } \\
\text { Képességszintek }\end{array}$ & Komponálás síkban & Absztrakció & Szimbolizáció & Modalitásváltás \\
\hline $\begin{array}{l}\text { Vizuális } \\
\text { felismerés }\end{array}$ & $\begin{array}{l}\text { hidegszinekegerkes_ } \\
4 \\
\text { leplekoroszlan_4 } \\
\text { leplekalatt2_4 } \\
\text { mozdulatok_w1_4 } \\
\text { mozdulatok_w2_4 } \\
\text { mozdulatok_w3_4 } \\
\text { mozdulatok_w4_4 }\end{array}$ & $\begin{array}{l}\text { terkep_v5_456 } \\
\text { terkep_v4_456 } \\
\text { terkep_v3_456 } \\
\text { terkep_v2_456 } \\
\text { terkep_v6_456 } \\
\text { szavakesabrak4_v1_4 } \\
\text { szavakesabrak4_v2_4 } \\
\text { szavakesabrak4_v3_4 } \\
\text { szavakesabrak4_v4_4 } \\
\text { szavakesabrak4_v5_4 }\end{array}$ & $\begin{array}{l}\text { piktogram_v1_45 } \\
\text { piktogram_v2_45 } \\
\text { piktogram_v4_45 } \\
\text { piktogram_v5_45 } \\
\text { piktogram_v6_45 } \\
\text { piktogram_v7_45 } \\
\text { piktogram_v8_45 }\end{array}$ & \\
\hline $\begin{array}{l}\text { Vizuális } \\
\text { értelmezés }\end{array}$ & $\begin{array}{l}\text { szinarnyalatok_gyon } \\
\text { gyszinezes_4 } \\
\text { haring_kepkivagas_4 } \\
\text { mozgalmas_m1_4 }\end{array}$ & $\begin{array}{l}\text { bukfenc_4 } \\
\text { pontmozgasa3_v1_45 } \\
6 \\
\text { pontmozgasa3_v2_45 }\end{array}$ & $\begin{array}{l}\text { sarkany_4 } \\
\text { piktogramoktelapo_ } \\
4 \\
\text { csaladfa_4 }\end{array}$ & $\begin{array}{l}\text { varazslobenedek_v1_4 } \\
\text { varazslobenedek_v2_4 } \\
\text { varazslobenedek_v3_4 } \\
\text { varazslobenedek_v4_4 }\end{array}$ \\
\hline
\end{tabular}




\begin{tabular}{|c|c|c|c|c|}
\hline & $\begin{array}{l}\text { mozgalmas_nm1_4 } \\
\text { szinkeveresharomszir } \\
\text { muvirag_4 }\end{array}$ & $\begin{array}{l}6 \\
\text { pontmozgasa3_v3_45 } \\
6 \\
\text { pontmozgasa3_v4_45 } \\
6 \\
\text { pontmozgasa3_v5_45 } \\
6 \\
\text { szavakesabrak3_v1_4 } \\
56 \\
\text { szavakesabrak3_v2_4 } \\
56 \\
\text { szavakesabrak3_v5_4 } \\
56 \\
\text { szavakesabrak3_v4_4 } \\
56\end{array}$ & Gainsborough_4 & $\begin{array}{l}\text { zene1_w1_456 } \\
\text { zene1_w2_456 } \\
\text { zene1_w3_456 } \\
\text { zene1_w4_456 } \\
\text { zene2_w1_456 } \\
\text { zene2_w2_456 } \\
\text { zene2_w3_456 } \\
\text { zene2_w4_456 }\end{array}$ \\
\hline Vizuális elemzés & & pontmozgasa_456 & & \\
\hline
\end{tabular}

A 432 tesztet kitöltő tanulóból 16 nem tudta befejezni a tesztet. A teszt kitöltésének pontot érő feladatban eltöltött átlagos ideje 29 perc (szórás $=8,9$ perc). A teljes teszten mért megoldási idő átlaga 39,7 perc (szórás $=12$ perc). A teljes teszten elérhető pontszám 58 , az elért pontszámok átlaga 39. Az elért pontszámok korrelációja a tesztben eltöltött idővel szignifikáns $(\mathrm{r}=0,3 \mathrm{p}<0,01)$. Az adatfelvétel elvárásainknak megfelelő, és egy tanóra alatt teljesíthető. A próbamérések során véglegesített teszt megbízhatósági mutatóit a teljes és a résztesztekre a 21. és a 22. táblázat foglalja össze. A teljes teszt reliabilitása magas (Cronbach- $\alpha=0,87)$. A szimbolizáció és a komponálás képességekhez tartozó résztesztek mutatóinak értéke alacsonyabb, de jó (Cronbach- $\alpha=0,62)$. Az absztrakció képességhez tartozó részteszt mutatója a legmagasabb (Cronbach- $\alpha=0,80)$. Ennek oka lehet, hogy ebben a dimenzióban szerepel legtöbb item. A negyedik évfolyamon értelmezett két képességszint, a vizuális felismerés és a vizuális értelmezés mutatóit megfigyelve láthatjuk, hogy mindkét szinten hasonlóan jó a megbízhatóság

21. táblázat A vizuális kommunikációs képességet mérö teszt megbizhatósági-mutatói képességcsoportok szerint 4. évfolyamon

\begin{tabular}{lccc}
\hline $\begin{array}{l}\text { Részképességek } \\
\text { megnevezése }\end{array}$ & Itemek száma & Cronbach- $\alpha$ & N (érvényes elemszám) \\
\hline \hline Komponálás & 12 & 0,62 & 416 \\
Absztrakció & 21 & 0,80 & 417 \\
Szimbolizáció & 11 & 0,62 & 416 \\
Modalitásváltás & 12 & 0,70 & 422 \\
Teljes vizuális & 57 & 0,87 & 416 \\
kommunikáció teszt & & & \\
\hline
\end{tabular}

22. táblázat A vizuális kommunikációs képességet mérő teszt megbízhatósági-mutatói képességszintek szerint 4. évfolyamon

\begin{tabular}{lccc}
\hline \hline $\begin{array}{l}\text { Képességszintek } \\
\text { megnevezése }\end{array}$ & $\begin{array}{c}\text { Itemek } \\
\text { száma }\end{array}$ & Cronbach- $\alpha$ & N (érvényes elemszám) \\
\hline \hline Vizuális felismerés & 24 & 0,83 & 421 \\
Vizuális értelmezés & 29 & 0,80 & 416 \\
\hline
\end{tabular}

A teljes teszt reliabilitás vizsgálatának item szintü mutatóit a 5. mellékletben közöljük. Az itemek elkülönítés mutatóinak gyakoriságát a 17. ábra mutatja be. 


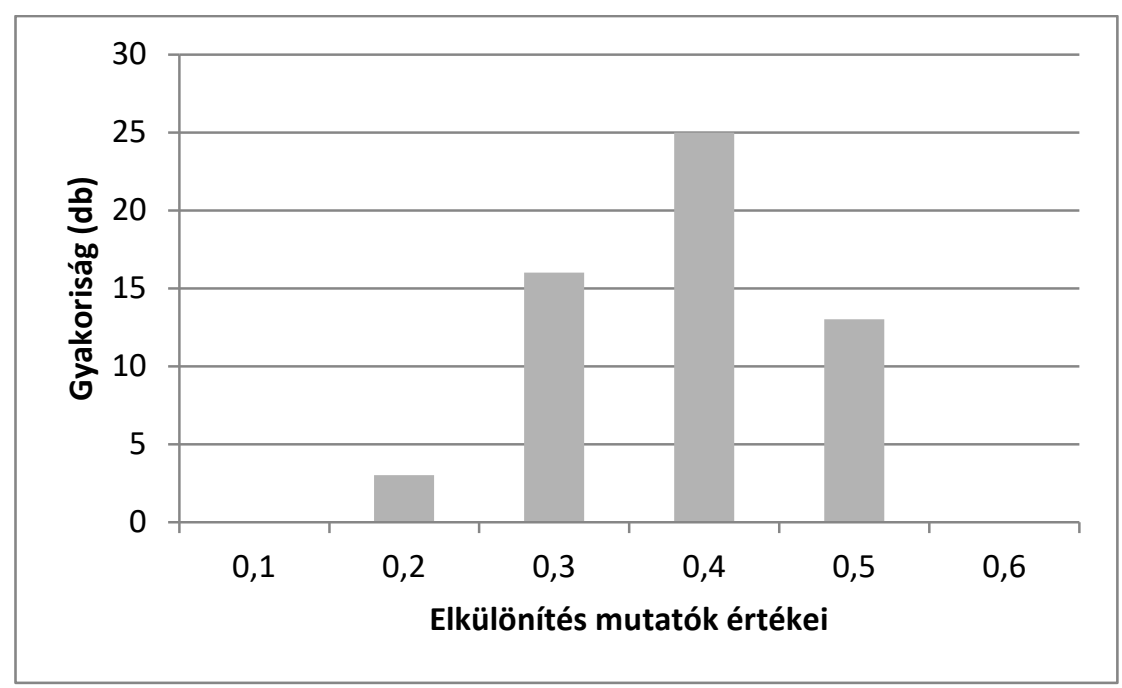

17. ábra Az itemek elkülönitési mutatóinak eloszlási gyakorisága 4. évfolyamon

A komponálás szinkeveresharomszirmuvirag_4 címü feladata (1. melléklet) negatívan korrelál a teljes teszttel, elkülönítés mutatója közelít a nullához, tehát a feladat nem megfelelően müködik. Ezért ezt a feladatot kivettük az elemzésekből. Így a részteszt és a teljes teszt szintjén is javult a megbízhatóság. A többi feladat elvárásainknak megfelelően mér. További egy item mutatója alacsony, de eltávolítása nem javítja érdemben sem a résztesztek, sem a teljes teszt megbízhatóságát, ezért ezt megtartottuk. Összességében megállapíthatjuk, hogy a teszt megbízhatóan mér és előzetes elvárásainknak megfelelően müködik a negyedik évfolyamon.

$\mathrm{Az}$ itemek és a teszt müködéséről kapott információkat tovább árnyalhatjuk a valószínűségi tesztelmélet módszereivel. Az EAP/PV reliabilitás mutató értéke magas, 0,84. Az eredmények személy-item térképét a 18. ábrán találhatjuk. Az ábra bal oldalán lévő skála az itemek nehézségét és a tanulók képességszintjét mutatja. Az x-ek a tanulókat jelentik, minden x 0,8 tanulót reprezentál. A jobb oldalon az itemek számát látjuk. Észlelhető, hogy az itemek az átlagos és annál magasabb képességszinteket fedik le. Alacsonyabb képességszinten a teszt kevésbé felel meg az előzetes elvárásainknak, nem vagy alig szelektál. Az ábráról leolvasható, hogy három item $(2,4,6)$ nagyon könnyünek bizonyult, ezért müködésük kevésbé megfelelö. Ezek az itemek egy feladathoz tartoznak, a szimbolizáció képességet felismerés szinten mérik. Ha megvizsgáljuk ezeknek az itemeknek átlagait (23. táblázat) alátámasztják az ábrán látható következtetést, mely szerint ezek az itemek túl könnyünek bizonyultak, nincs differenciáló erejük.

23. táblázat A Piktogram címü feladat itemeinek átlaga és szórása 4. évfolyamban

\begin{tabular}{lcc}
\hline \hline Itemnév & Átlag & Szórás \\
\hline \hline 2. piktogram_v2_45 & 0,96 & 0,19 \\
4. piktogram_v4_45 & 0,94 & 0,24 \\
6.piktogram_v6_45 & 0,83 & 0,38 \\
\hline
\end{tabular}




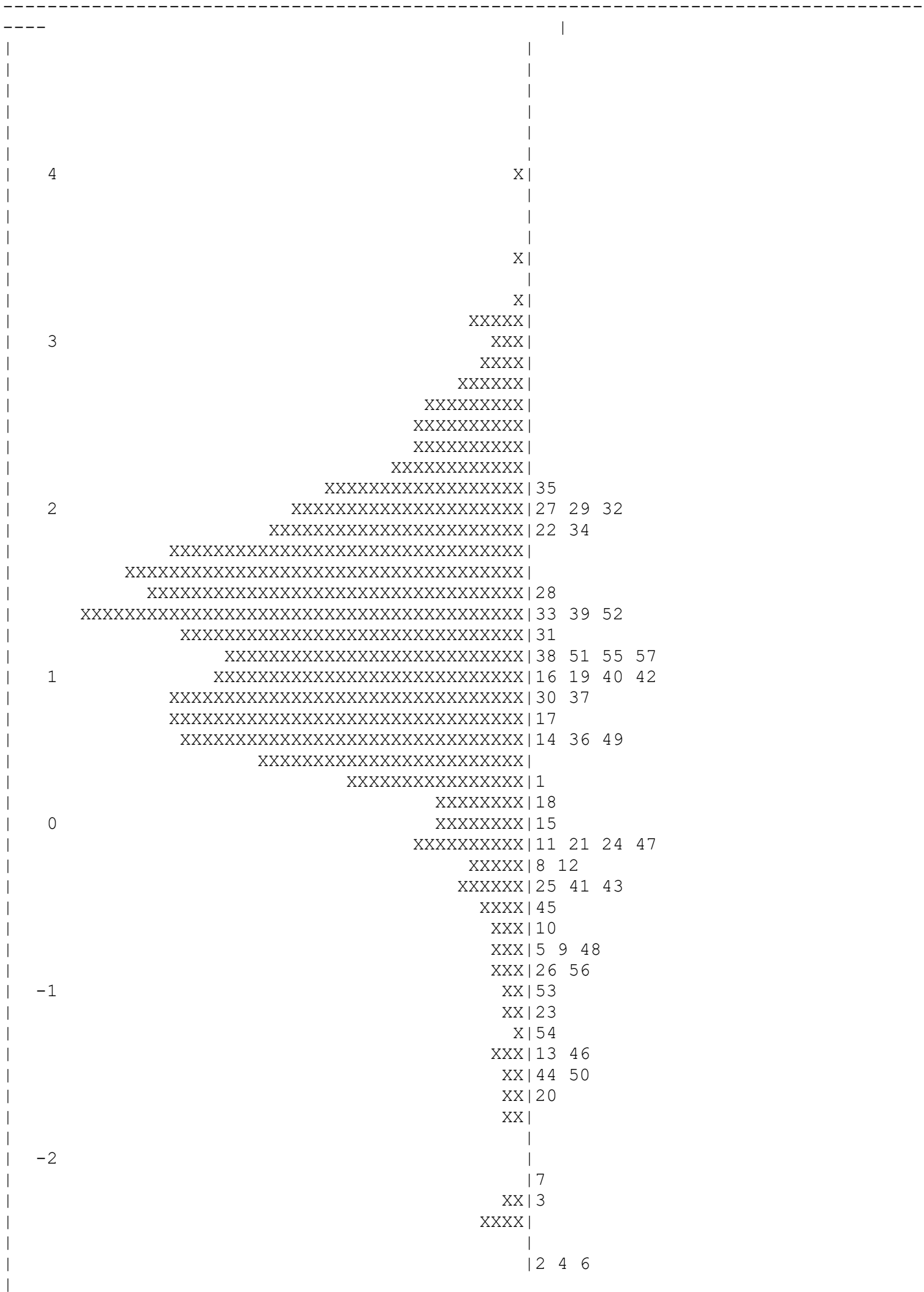

18. ábra A 4. évfolyamos vizuális kommunikációs képességet mérö teszt személy-item térképe. 
A teszt belső struktúrájának vizsgálatához visszatekintünk a 21. táblázathoz, a reliabilitás mutatókból jól látható, hogy teljes teszt megbízhatósága a legmagasabb. A nagyobb itemszámú részteszt megbízhatósága közelít a teljes teszt megbízhatósági mutatójához. A résztesztek közötti korrelációk vizsgálatával tovább elemezhetjük a tesztet, melyet a 24. táblázatban foglaltuk össze. Az összefüggés közepes erősségü az egyes részterületek között, de a teljes teszttel magas korrelációt tapasztalunk minden dimenzióban. A legmagasabb együtt járás a komponálás és az absztrakció résztesztek között figyelhető meg. Az erős összefüggés utalhat egy látens pszichológiai konstruktum létezésére, melyet az adott résztesztek egyaránt mérnek.

24. táblázat A résztesztek és a teljes teszt közötti korrelációs együtthatók 4. évfolyamon

\begin{tabular}{|c|c|c|c|c|}
\hline & 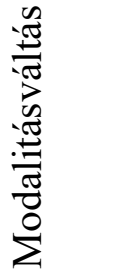 & 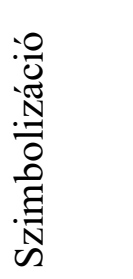 & 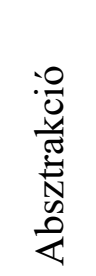 & 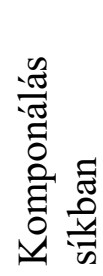 \\
\hline Szzimbolizáció & 0,38 & & & \\
\hline Absztrakció & 0,44 & 0,46 & & \\
\hline Komponálás & 0,42 & 0,51 & 0,55 & \\
\hline Teljes teszt & 0,73 & 0,69 & 0,87 & 0,77 \\
\hline
\end{tabular}

Megj.: Minden korreláció szignifikáns $p<0,01$ szinten.

A részkonstruktumok alaposabb feltárása érdekében konfirmatív faktoranalízist (CFA Confirmatory Factor Analysis) végeztünk.

25. táblázat A 4, évfolyamos vizuális kommunikációs képességet mérö teszt megerősitö faktorelemzésének eredményei

\begin{tabular}{lllllll}
\hline \hline Modell & $\chi 2$ & $\mathrm{p}$ & $\mathrm{df}$ & CFI & TLI & RMSEA (95\% CI) \\
\hline \hline 4.évfolyam & 1746,13 & 0,00 & 703 & 0.679 & 0,658 & $0,063(0,059-0,067)$ \\
\hline \\
Megjegyzés: $d f=$ degrees of freedom; CFI = Comparative Fit Index; TLI = Tucker-Lewis Index; RMSEA \\
Root Mean Square Error of Approximation; $\chi 2$ and df are estimated by WLSMV.
\end{tabular}

A 25. táblázat értékeit elemezve megállapítható, hogy a modell illeszkedési mutatói kevésbé megfelelőek (CFI és TLI $<0,90)$, tehát a hipotetikus modellünk gyengén illeszkedik a mért konstruktumhoz. Ez arra utal, hogy a vizsgált részképességet mérő tesztrészletek többdimenziósak. Az egyes dimenziókon belüli itemek közötti korreláció ugyan szignifikáns, de közepes erösségü vagy gyenge. Ennek oka az lehet, hogy az itemek összetettek képi tartalomban, szövegben egyaránt. A tesztfejlesztés következő fázisa lehet ennek a problémának a kiküszöbölése és jól illeszkedő egydimenziós modell létrehozása. Ehhez mindenképp egyszerüsíteni szükséges a feladatokat, vagy a vizuális kommunikáció kisebb területét felölelve, tartalomban és müveletben egyaránt, újabb feladatokat készíteni. 


\subsubsection{A vizuális kommunikációs képesség teszt pszichometriai jellemzői 5. évfolyamban}

Az 5. évfolyamos vizuális kommunikációs képességet mérő teszt négy képességelemből áll és három képességszinthez tartozik (26. táblázat).

26. táblázat Értékelö feladatok a vizuális képességcsoport részképességeihez, szintenként 5. évfolyamon

\begin{tabular}{|c|c|c|c|c|}
\hline $\begin{array}{l}\text { Részképességek } \\
\text { Képességszintek }\end{array}$ & Komponálás síkban & Absztrakció & Szimbolizáció & Modalitásváltás \\
\hline $\begin{array}{l}\text { Vizuális } \\
\text { felismerés }\end{array}$ & leplekalatt2_56 & $\begin{array}{l}\text { terkep_v5_456 } \\
\text { terkep_v4_456 } \\
\text { terkep_v3_456 } \\
\text { terkep_v2_456 } \\
\text { terkep_v6_456 }\end{array}$ & $\begin{array}{l}\text { piktogram_v1_45 } \\
\text { piktogram_v2_45 } \\
\text { piktogram_v4_45 } \\
\text { piktogram_v5_45 } \\
\text { piktogram_v6_45 } \\
\text { piktogram_v7_45 } \\
\text { piktogram_v8_45 }\end{array}$ & $\begin{array}{l}\text { egyiptomiistenek2_v1_ } \\
5 \\
\text { egyiptomiistenek2_v2_ } \\
5 \\
\text { egyiptomiistenek2_v3_ } \\
5 \\
\text { egyiptomiistenek2_v4 } \\
5\end{array}$ \\
\hline $\begin{array}{l}\text { Vizuális } \\
\text { értelmezés }\end{array}$ & $\begin{array}{l}\text { szirnyalatok_gyongyszin } \\
\text { ezes_5 } \\
\text { mondrian_kepkivagas_5 } \\
6 \\
\text { lenka_kepkivagas_5 } \\
\text { okeffee_v1_56 } \\
\text { okeffee_v2_56 } \\
\text { okeffee_v3_56 } \\
\text { mozgalmas_m1_5 } \\
\text { mozgalmas_nm1_5 } \\
\text { picasso_v1_56 } \\
\text { picasso_v2_56 } \\
\text { picasso_v3_56 } \\
\text { picasso_v4_56 } \\
\text { picasso_v5_56 } \\
\text { hokkontraszt_v1_meleg_ } \\
5 \\
\text { hofokkontraszt_v2_hideg } \\
5\end{array}$ & $\begin{array}{l}\text { gerenda_5 } \\
\text { pontmozgasa3_v1 } \\
\text {-456 } \\
\text { pontmozgasa3_v2 } \\
\text {-456 } \\
\text { pontmozgasa3_v3 } \\
\text { _456 } \\
\text { pontmozgasa3_v4 } \\
\text { _456 } \\
\text { pontmozgasa3_v5 } \\
\text {-456 } \\
\text { szavakesabrak3_v } \\
\text { 1_456 } \\
\text { szavakesabrak3_v } \\
\text { 2_456 } \\
\text { szavakesabrak3_v } \\
\text { 5_456 } \\
\text { szavakesabrak3_v } \\
\text { 4_456 } \\
\text { szavakesabrak2_v } \\
\text { 2_56 } \\
\text { szavakesabrak2_v } \\
\text { 3_56 } \\
\text { szavakesabrak2_v } \\
\text { 4_56 } \\
\text { szavakesabrak2_v } \\
\text { 5_56 } \\
\text { szavakesabrak2_v } \\
\text { 6_56 }\end{array}$ & $\begin{array}{l}\text { piktogramfurulya_4 } \\
56 \\
\text { piktogram_ketchup } \\
\text {-5 }\end{array}$ & $\begin{array}{l}\text { zene1_w1_456 } \\
\text { zene1_w2_456 } \\
\text { zene1_w3_456 } \\
\text { zene1_w4_456 } \\
\text { zene2_w1_456 } \\
\text { zene2_w2_456 } \\
\text { zene2_w3_456 } \\
\text { zene2_w4_456 } \\
\text { palacsintasorrend_5 }\end{array}$ \\
\hline Vizuális elemzés & $\begin{array}{r}\text { szinelemzes_v1_56 } \\
\text { szinelemzes_v2_56 } \\
\text { szinelemzes_v3_56 } \\
\text { szinelemzes_v4_56 } \\
\text { batman2_56 }\end{array}$ & pontmozgasa_456 & & \\
\hline
\end{tabular}

A 338 kitöltésböl 317 érvényes kitöltés született. Az elérhetö 64 pontból 43,89 pontot (szórás $=9,48$ ) értek el a tanulók. Pontot érő feladatban 28,5 percet (szórás=7,99 perc), a teljes tesztben 38,79 percet (szórás $=10,27$ perc) töltöttek a tanulók. Az elért pontszámok szignifikáns összefüggést mutatnak a tesztben eltöltött idővel $(\mathrm{r}=0,3 \mathrm{p}<0,01)$. Az adatfelvétel 
egy tanóra alatt történt, ahogyan azt elözetesen terveztük. A próbamérések során véglegesített teszt megbízhatósági mutatóit a 27. táblázat mutatja be. A teljes teszt megbízhatósági mutatója kifejezetten magas (Cronbach- $\alpha=0,89$ ). A legmagasabb érték a modalitásváltás képességet mérő részteszthez tartozik (Cronbach- $\alpha=0,84$ ), ami közelít a teljes teszt reliabilitásához. A képességszinten végzett elemzésből (28. táblázat) jól látható, hogy a vizuális elemzés szinten legalacsonyabb a megbízhatósági mutató. Ez valószínűsíthetően az alacsony itemszámnak köszönhetö.

27. táblázat A vizuális kommunikációs képességet mérö teszt belső konzisztencia-mutatói képességcsoportok szerint 5. évfolyamon

\begin{tabular}{lccc}
\hline \hline $\begin{array}{l}\text { Részképességek } \\
\text { megnevezése }\end{array}$ & Itemek száma & Cronbach- $\alpha$ & $\begin{array}{l}\text { N (érvényes } \\
\text { elemszám) }\end{array}$ \\
\hline \hline Komponálás & 20 & 0,75 & 324 \\
Absztrakció & 20 & 0,77 & 331 \\
Szimbolizáció & 9 & 0,67 & 337 \\
Modalitásváltás & 36 & 0,84 & 331 \\
$\begin{array}{l}\text { Teljes vizuális } \\
\text { kommunikáció teszt }\end{array}$ & 64 & 0,89 & 317 \\
\hline
\end{tabular}

28. táblázat A vizuális kommunikációs képességet mérö teszt belső konzisztencia-mutatói képességszintek szerint 5.. évfolyamon

\begin{tabular}{lccc}
\hline \hline $\begin{array}{l}\text { Képességszintek } \\
\text { megnevezése }\end{array}$ & $\begin{array}{l}\text { Itemek } \\
\text { száma }\end{array}$ & Cronbach- $\alpha$ & N (érvényes elemszám) \\
\hline \hline Vizuális felismerés & 17 & 0,77 & 335 \\
Vizuális értelmezés & 41 & 0,86 & 328 \\
Vizuális elemzés & 6 & 0,48 & 328 \\
\hline
\end{tabular}

A teljes teszt reliabilitás vizsgálatának item szintü mutatóit a 6. mellékletben közöljük. Az itemek elkülönítés mutatóinak gyakoriságát a 19. ábra mutatja be. A komponálás egyik feladatának (batman2_56) (1. melléklet) elkülönítésmutatója közelít a nullához. Bár még ezzel a feladattal együtt is megbízhatóan mér a részteszt, ennek ellenére eltávolítottuk a feladatot a tesztből, mivel egyéb mutatói is nagyon alacsonyak voltak (átlag=0,03 szórás $=0,18$ ). Jóságmutatók alapján megállapíthatjuk, hogy az ötödik évfolyamos teszt előzetes elvárásainknak megfelelően müködik. 


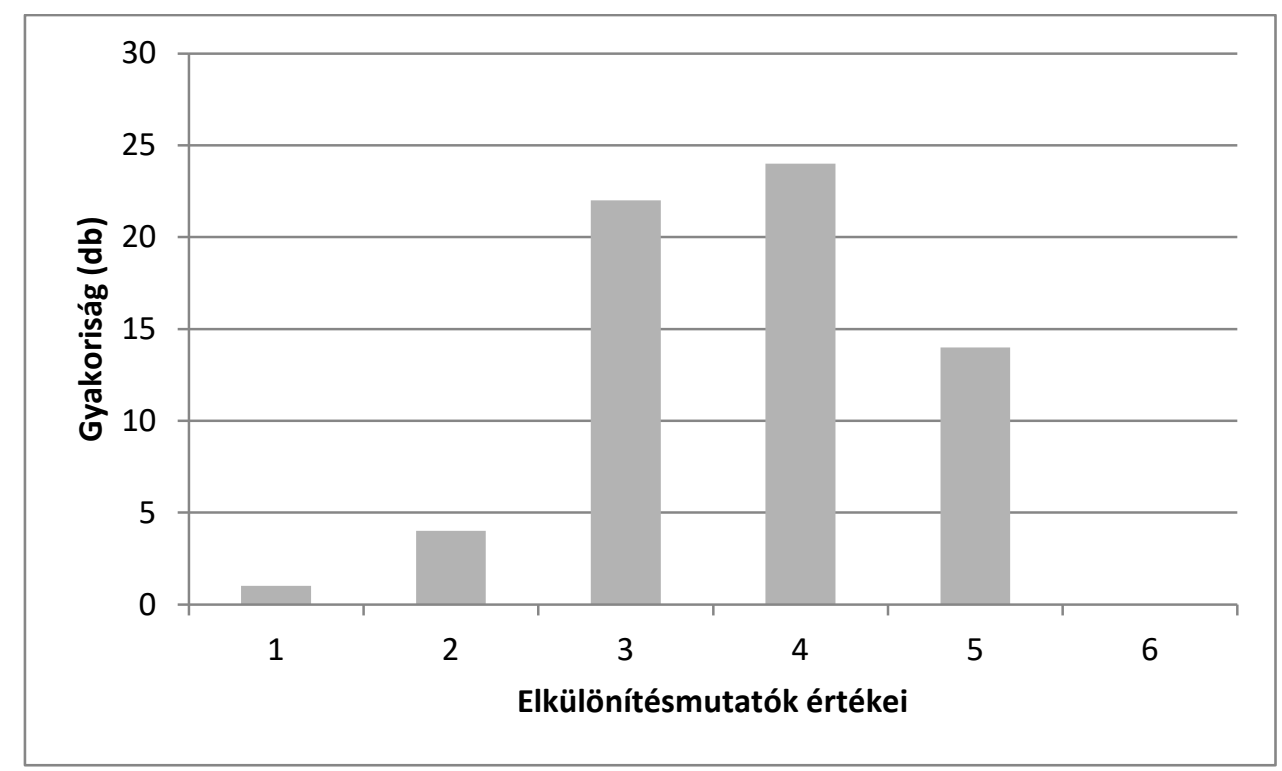

19. ábra Az itemek elkülönitési mutatóinak eloszlási gyakorisága 5. évfolyamon

Az itemek és a teszt müködéséről további részleteket tudunk meg a valószínüségi tesztelmélet módszereivel. Az EAP/PV reliabilitás mutató értéke 0,83. A 20. ábra bal oldalán lévő skála a feladatok nehézségét és a tanulók képességszintjét mutatja. Az X-ek a tanulókat jelentik, minden x 0,6 tanulót reprezentál. A jobb oldalon az itemek számát látjuk. Láthatjuk, hogy az itemek az átlagos és annál magasabb képességszinteket fedik le. Alacsonyabb képességszinten a teszt kevésbé felel meg az előzetes elvárásainknak. Az ábráról leolvasható, hogy a 2., 3., 4., 6. és a 7. item müködése kevésbé megfelelö, melyekböl három egyezik a negyedikes teszt nem az elvárásoknak megfelelő itemeivel. Az itemek átlagai és szórása alátámasztja ezt (29. táblázat).

29. táblázat A Piktogram címü feladat itemeinek átlaga és szórása 5. évfolyamban

\begin{tabular}{lcc}
\hline \hline Itemnév & Átlag & Szórás \\
\hline \hline piktogram_v2 & 0,97 & 0,16 \\
piktogram_v4 & 0,95 & 0,21 \\
piktogram_v5 & 0,98 & 0,14 \\
piktogram_v7 & 0,98 & 0,14 \\
piktogram_v8 & 0,97 & 0,17 \\
\hline
\end{tabular}


XXXXXXXXXXXXXXXXXXXXXXXXXXXXXXXXXXXXXXX|18 XXXXXXXXXXXXXXXXXXXXXXXXXXXXXXXXX|4158 XXXXXXXXXXXXXXXXXXXXXXXX|19 $23 \quad 54$ XXXXXXXXX|1 $35 \quad 38 \quad 40 \quad 46$ XXXXXXXXX|24 $52 \quad 55 \quad 64$ XXXXXXXXXXX|51 53 $\mathrm{XXXX} \mid 59$

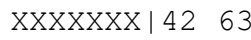
$\mathrm{x} \times \mathrm{XX} \mid 33$ $x \times x \mid 56 \quad 6061$ $\mathrm{X} \mid$ $x \mid 27 \quad 28 \quad 50$

20. ábra Az 5. évfolyamos vizuális kommunikációs képességet mérö teszt személy-item térképe.. 
A résztesztek közötti korrelációkat a 30. táblázatban foglaltuk össze. Az összefüggés erős az egyes részterületek és a teljes teszt között egyaránt $(0,62<\mathrm{r}<0,88)$. Mindegyik összefüggés szignifikáns $(\mathrm{p}<0,01)$. A résztesztek esetén a komponálás és az absztrakció között a legerősebb az együtt járás, de nem kiugróan magas $(\mathrm{r}=0,65)$. Az erős korreláció utalhat tartalomban és műveletben egyaránt egy látens pszichológiai konstruktum létezésére. A szimbolizáció és a modalitásváltás között biztos, de gyenge a kapcsolat $(r=0,35)$. A többi dimenzió között közepes korreláció figyelhető meg.

30. táblázat A résztesztek és a teljes teszt közötti korrelációs együtthatók 5. évfolyamon

\begin{tabular}{|c|c|c|c|c|}
\hline & 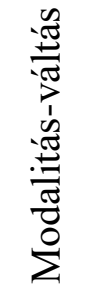 & 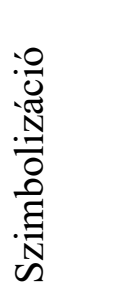 & 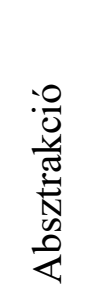 & 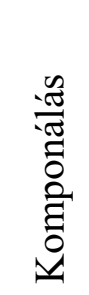 \\
\hline Szimbolizáció & 0,35 & & & \\
\hline Absztrakció & 0,54 & 0,45 & & \\
\hline Komponálás & 0,50 & 0,49 & 0,65 & \\
\hline $\begin{array}{l}\text { Teszten elért } \\
\text { teljesítmény }\end{array}$ & 0,76 & 0,62 & 0,88 & 0,87 \\
\hline
\end{tabular}

Megj.: Minden korreláció szignifikáns $p<0,01$ szinten.

A mért és a hipotetikus modell struktúrájának feltárásához, hasonlóan a negyedik évfolyamos teszthez, konfirmatív faktoranalízist végeztünk.

31. táblázat Az 5. évfolyamos vizuális kommunikációs képességet mérő teszt megerösitő faktorelemzésének eredményei

\begin{tabular}{lcccccr}
\hline \hline Modell & $\chi 2$ & $\mathrm{p}$ & $\mathrm{df}$ & CFI & TLI & RMSEA (95\% CI) \\
\hline \hline 5.évfolyam & 3144,69 & 0,00 & 1371 & 0.742 & 0,731 & $0,063(0,060-0,066)$ \\
\hline \\
Megjegyzés: $d f=$ degrees of freedom;
\end{tabular}

A 31. táblázat értékeit megvizsgálva láthatjuk, hogy az ötödik évfolyamos részkonstruktum illeszkedése jobb, mint a negyedik évfolyamos teszté. Azonban ebben az esetben is az illeszkedés alul marad az elvártnál (CFI, TLI < 0,90). Az okok hasonlóak. A résztesztek egyes itemei közötti korrelációk nem magasak, ami elsősorban az itemek összetettségének tudható be. A jövőbeli tesztfejlesztés során célszerű szükíteni a kutatási terület tartalmát, egyszerüsíteni képanyagát. Mivel a szakirodalmat áttekintve nem találtunk hasonló kutatást, ígéretesnek értékeljük az eredményeket, mint első lépést a vizuális kommunikációs képesség technológiai alapú mérésében.

\subsubsection{A vizuális kommunikációs képesség teszt pszichometriai jellemzői 6. évfolyamban}

A 6. évfolyamos teszt, hasonlóan a 4. és 5. évfolyamos tesztekhez, négy képességhez kapcsolódó itemeket tartalmaz. A képességek mérését három szinten végeztük (32. táblázat). 
32. táblázat Értékelö feladatok a vizuális képességcsoport részképességeihez, szintenként 6. évfolyamon

\begin{tabular}{|c|c|c|c|c|}
\hline $\begin{array}{l}\text { Részképességek } \\
\text { Képességszintek }\end{array}$ & Komponálás síkban & Absztrakció & Szzimbolizáció & Modalitásváltás \\
\hline $\begin{array}{l}\text { Vizuális } \\
\text { felismerés }\end{array}$ & $\begin{array}{l}\text { mozdulatok3_v1_6 } \\
\text { mozdulatok3_v2_6 } \\
\text { mozdulatok3_v3_6 } \\
\text { mozdulatok3_v4_6 } \\
\text { leplekalatt2_56 }\end{array}$ & $\begin{array}{l}\text { terkep_v5_456 } \\
\text { terkep_v4_456 } \\
\text { terkep_v3_456 } \\
\text { terkep_v2_456 } \\
\text { terkep_v6_456 }\end{array}$ & & $\begin{array}{l}\text { gorogmitologiailenyek } \\
\text { _v1_6 } \\
\text { gorogmitologiailenyek } \\
\text { _v2_6 } \\
\text { gorogmitologiailenyek } \\
\text { _v3_6 } \\
\text { gorogmitologiailenyek } \\
\text { _v4_6 } \\
\text { gorogmitologiailenyek } \\
\text { _v5_6 }\end{array}$ \\
\hline $\begin{array}{l}\text { Vizuális } \\
\text { értelmezés }\end{array}$ & $\begin{array}{l}\text { mondrian_kepkivagas_5 } \\
6 \\
\text { okeffee_v1_56 } \\
\text { okeffee_v2_56 } \\
\text { okeffee_v3_56 } \\
\text { picasso_v1_56 } \\
\text { picasso_v2_56 } \\
\text { picasso_v3_56 } \\
\text { picasso_v4_56 } \\
\text { picasso_v5_56 }\end{array}$ & $\begin{array}{l}\text { metro_v1_6 } \\
\text { metro_v2_6 } \\
\text { metro_v3_6 } \\
\text { metro_v4_6 } \\
\text { topografia_v1_6 } \\
\text { topografia_v2_6 } \\
\text { topografia_v3_6 } \\
\text { topografia_v4_6 } \\
\text { topografia_v5_6 } \\
\text { pontmozgasa3_v1 } \\
\text {-456 } \\
\text { pontmozgasa3_v2 } \\
\text {-456 } \\
\text { pontmozgasa3_v3 } \\
\text {-456 } \\
\text { pontmozgasa3_v4 } \\
\text {-456 } \\
\text { pontmozgasa3_v5 } \\
\text {-456 } \\
\text { szavakesabrak3_v } \\
\text { 1_456 } \\
\text { szavakesabrak3_v } \\
\text { 2_456 } \\
\text { szavakesabrak3_v } \\
\text { 5_456 } \\
\text { szavakesabrak3_v } \\
4 \text { 456 } \\
\text { szavakesabrak2_v } \\
\text { 2_56 } \\
\text { szavakesabrak2_v } \\
\text { 3_56 } \\
\text { szavakesabrak2_v } \\
4 \text { 4_56 } \\
\text { szavakesabrak2_v } \\
\text { 5_56 } \\
\text { szavakesabrak2_v } \\
6 \text { 6_56 }\end{array}$ & $\begin{array}{l}\text { piktogramfurulya_4 } \\
56\end{array}$ & $\begin{array}{l}\text { zene1_w1_456 } \\
\text { zene1_w2_456 } \\
\text { zene1_w3_456 } \\
\text { zene1_w4_456 } \\
\text { zene2_w1_456 } \\
\text { zene2_w2_456 } \\
\text { zene2_w33456 } \\
\text { zene2_w4_456 } \\
\text { tornagyakorlatok2_v1_ } \\
6 \\
\text { tornagyakorlatok2_v2_ } \\
6 \\
\text { tornagyakorlatok2_v3 } \\
6 \\
\text { tornagyakorlatok2_v4_ } \\
6\end{array}$ \\
\hline $\begin{array}{l}\text { Vizuális } \\
\text { elemzés }\end{array}$ & $\begin{array}{l}\text { szinelemzes_v1_56 } \\
\text { szinelemzes_v2_56 } \\
\text { szinelemzes_v3_56 } \\
\text { szinelemzes_v4_56 } \\
\text { lovak_6 } \\
\text { warhol2_6 } \\
\text { batman2_56 }\end{array}$ & pontmozgasa_456 & $\begin{array}{l}\text { tavasz_6 } \\
\text { haring1_v1_6 } \\
\text { haring1_v2_6 } \\
\text { haring1_v3_6 }\end{array}$ & \\
\hline
\end{tabular}


A 6. évfolyamos tesztet 486 tanuló töltötte ki, ebből érvényes 482 (99\%) kitöltés. A tanulók pontot érő feladatban eltöltött átlagos ideje 27,68 perc (szórás=11,44 perc). A teljes tesztben 36,11 perc (szórás $=11,53$ perc). A teszten elérhető pontszám 72 , az elért pontszámok átlaga 49, 21 (szórás=10,95). Az adatfelvétel egy óra alatt megvalósulhat, ahogy azt előzetesen terveztük. A pontosabb mérés érdekében több feladat is belefér az időkeretbe. A pilotmérések során véglegesített teszt megbízhatósági mutatóit a teljes és a résztesztekre a 33. és a 34. táblázat foglalja össze. A teljes teszt reliabilitása magas (Cronbach- $\alpha=0,89$ ). Az itemekre bontott teszt elkülönítésmutatói között egy feladat (batman2_56) (1. melléklet) mutatója közelít a nullához és ellentétesen korrelál a teljes teszttel. Ezt az elemet eltávolítottuk a tesztböl az összefüggés vizsgálatok elvégzésekor. A teljes teszt reliabilitásának itemszintü mutatóit a 7. mellékletben közöljük. A 21. ábra az itemek elkülönítési mutatóinak gyakoriságát mutatja be 6 . évfolyamon.

33. táblázat A vizuális kommunikációs képességet mérö teszt megbizhatósági-mutatói képességcsoportok szerint 6. évfolyamon

\begin{tabular}{lccc}
\hline $\begin{array}{l}\text { Részképességek } \\
\text { megnevezése }\end{array}$ & Itemek száma & Cronbach- $\alpha$ & $\begin{array}{c}\mathrm{N} \\
\text { elemszám) }\end{array}$ \\
\hline \hline Komponálás & 21 & 0,71 & 486 \\
Absztrakció & 29 & 0,86 & 482 \\
Szimbolizáció & 5 & 0,54 & 486 \\
Modalitásváltás & 17 & 0,75 & 483 \\
Teljes vizuális & 72 & 0,89 & 482 \\
kommunikáció teszt & & & \\
\hline
\end{tabular}

34. táblázat A vizuális kommunikációs képességet mérö teszt megbizhatósági-mutatói képességszintek szerint 6. évfolyamon

\begin{tabular}{lccc}
\hline \hline $\begin{array}{l}\text { Képességszintek } \\
\text { megnevezése }\end{array}$ & $\begin{array}{l}\text { Itemek } \\
\text { száma }\end{array}$ & Cronbach- $\alpha$ & N (érvényes elemszám) \\
\hline \hline Vizuális felismerés & 15 & 0,69 & 482 \\
Vizuális értelmezés & 45 & 0,86 & 482 \\
Vizuális elemzés & 12 & 0,61 & 486 \\
\hline
\end{tabular}




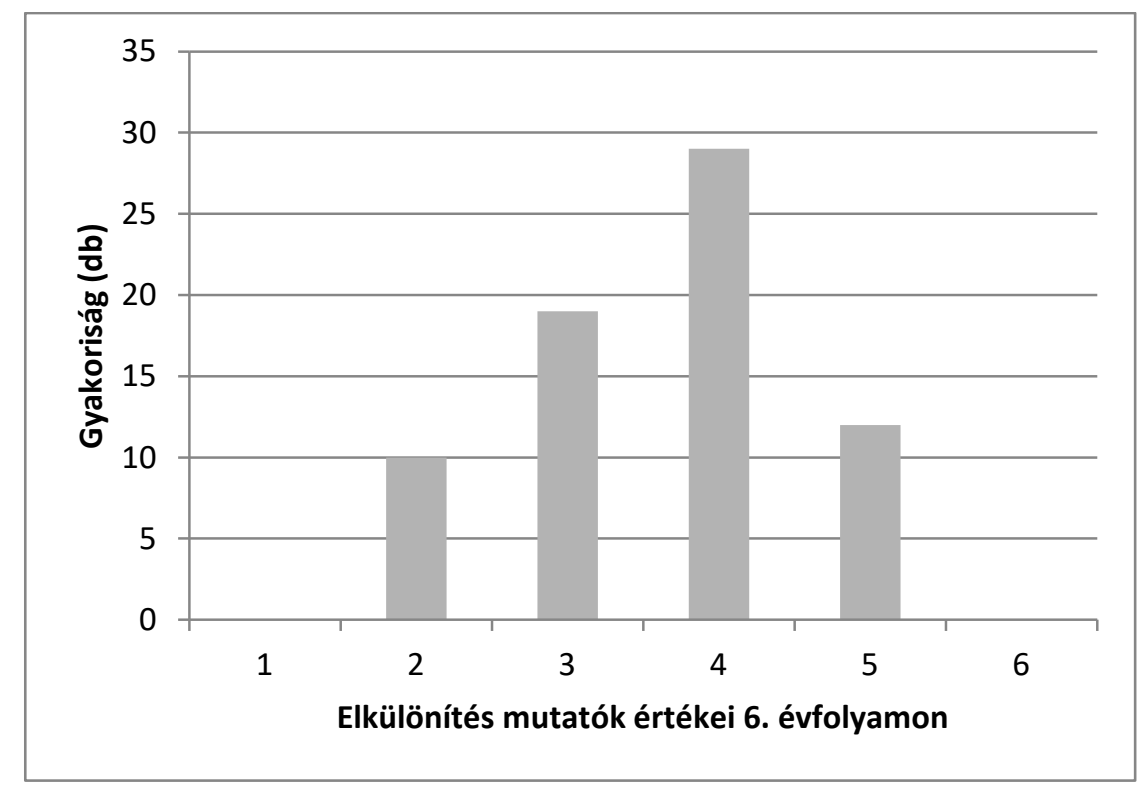

21. ábra A 6. évfolyam itemeinek elkülönités mutatóinak gyakorisága

A tesztet megvizsgáltuk a valószínüségi tesztelmélet módszereivel is. Az EAP/PV reliabilitás értéke 0,85. Az eredmények személy-item térképe a 22. ábrán látható. Az ábra bal oldalán a feladatok nehézségét és a tanulók képességszintjét mutató skála található. Az x-ek szimbolizálják a tanulókat, minden x 0,9 tanulót reprezentál. Az itemek az átlagos képességszintet fedik le, enyhén eltolódik a magasabb értékek felé. Az ábrán jól látható, hogy a 19., 27., 42., 60. itemek túl könnyüenek bizonyultak ezen a mintán. Az átlagaikat megnézve, alátámasztják ezt az állítást (35. táblázat).

35. táblázat A személy-item térkép alapján könnyünek bizonyult itemek átlaga és szórása

\begin{tabular}{lll}
\hline \hline Itemnév & Átlag & Szórás \\
\hline \hline 19. szavakesabrak3_v5_456 & 0,91 & 0,29 \\
27. szinelemzes_v3_56 & 0,94 & 0,24 \\
42. picasso_v3_56 & 0,91 & 0,29 \\
60. gorogmitologiailenyek_v2_6 & 0,89 & 0,32 \\
\hline
\end{tabular}


logit paraméter

$x x \mid$

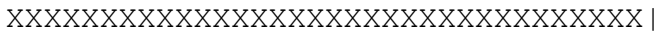

XXXXXXXXXXXXXXXXXXXXXXXXXXXX

1

XXXXXXXXXXXXXXXXXXXXXXXXXXXXXXXXXXXXXXXX 18

$$
\text { XXXXXXXXXXXXXXXXXXXXXXXXXXXXXXX|7 } 50
$$

$\begin{array}{llllll}X X X X X X X X X X X X X X X X X X X X X X X \mid 1 & 3 & 9 & 13 & 14\end{array}$

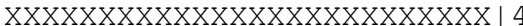

XXXXXXXXXXXXXXXXXXXXXXXXXXXXXX|l 62226

$\begin{array}{lllll}X X X X X X X X X X X X X X X X X X X X X X X X X \mid 12 & 15 & 24\end{array}$

XXXXXXXXXXXXXXXXXXXXXXXXXXXXXXXXXXXXX|11 $49 \quad 70$

$\begin{array}{llllll}X X X X X X X X X X X X X X X X X X X X X X X X \mid & 36 & 47 & 58 & 68 & 72\end{array}$

XXXXXXXXXXXXXXXXXXXXXX|35 57

$\begin{array}{llll}X X X X X X X X X X X \mid & 31 & 37 & 54\end{array}$

XXXXXXXXXXXXXXX|46 52

XXXXXXXXXXXXXXX|28 34

XXXXXXX|16 $17 \quad 33 \quad 44 \quad 56 \quad 65 \quad 66$

$\begin{array}{llll}X X X X X X X \mid 38 & 45 & 67 & 71\end{array}$

$\begin{array}{llll}X X X \mid 25 & 30 & 51 & 62\end{array}$

$\mathrm{XXX} \mid 43$

$\mathrm{XXXX} \mid 2064$

$\mathrm{XX} \mid 48 \quad 5963 \quad 69$

$\mathrm{XX} \mid \begin{array}{lll}23 & 40 & 41\end{array}$

$-1$

$\mathrm{xx} \mid \begin{array}{ll}18 & 21\end{array}$

13261

1

$\mathrm{xx} \mid 55$

14260

$\mathrm{X} \mid 53$

1

127

119

$-2$

$\mathrm{XX}$

$\mathrm{XXX}$ 
A résztesztek közötti kapcsolat alaposabb feltárása érdekében konfirmatív faktoreanalízis (CFA -Confirmatory Factor Analysis) végeztünk (36. táblázat).

36. táblázat A 6.. évfolyamos vizuális kommunikációs képességet mérö teszt megerősitö faktorelemzésének eredményei

\begin{tabular}{|c|c|c|c|c|c|c|}
\hline Modell & $x^{2}$ & $\mathrm{p}$ & df & CFI & TLI & RMSEA $(95 \%$ CI) \\
\hline 6.évfolyam & 6701,85 & 0,000 & 1431 & 0.587 & 0,569 & $0,057(0,055-0,060)$ \\
\hline
\end{tabular}

A 36. táblázat értékeit megvizsgálva megállapítható, hogy a modell gyengén illeszkedik. Megvizsgálva az résztesztek itemeinek korrelációit, szignifikáns, de alacsony értékeket találunk. Hasonlóan a másik két évfolyam tesztjeihez itt is az ok a feladatok összetettségében keresendő. A tartalmi és műveleti redukció a tesztfejlesztés következő lépése lehet.

\subsubsection{A vizuális kommunikációs képességet mérő tesztek pszichometriai jellemzőinek összegzése}

Összegezve a vizuális kommunikáció tesztek müködését megállapíthatjuk, hogy a mérőeszközök alkalmasak a vizuális kommunikációs képesség mérésére. Az eszköz egyben jól müködik, de a négy részképességet mérő résztesztek önmagukban nem alkalmasak a részképességek mérésére, erre az eszköz továbbfejlesztésével lesz lehetőség.

A reliabilitás mutatók, az IRT elemzés, a korrelációk és a konfirmatív faktoranalízis analízis alapján elmondhatjuk, hogy minden évfolyamon a vizsgált konstruktum rendezettsége és szerkezete a vártnál kevésbé stabil. Néhány területen a tesztek kevésbé jól mérnek, melyet alátámaszt az IRT elemzés személy-item térképe, miszerint vannak kevésbé jól müködő itemek a tesztekben és a teljesítmények között sem differenciálnak az elvárásainknak megfelelően. Ugyanakkor a mérőeszközök minden évfolyamon megbízhatóan müködnek, egy irányba mutatnak, a relibilitás mutatók értéke magas.

A konfirmatív faktorelemzés értékeit elemezve elmondható, hogy a mért konstruktum gyengén illeszkedik a hipotetikus modellhez. Ennek okát az itemek összetettségében látjuk. Az egyes dimenziók itemei közötti korrelációk közepesek vagy gyengék, tehát a résztesztek többdimenziósak. A tesztfejlesztés következő szakaszában valósulhat meg az a tartalmi és műveleti redukció, mely által konstruktum stabilizálódik, és jól illeszkedik a hipotetikus modellhez. Ugyanakkor az itemek és a résztesztek korrelációja a teljes teszttel egyaránt magas, tehát a teszt alkalmas a vizuális kommunikációs képesség mérésére, de a részképességekről nem kaphatunk információkat.

Az információk további árnyalásához elvégeztük az itemek és a személyek közös skálán való jellemzését, melyet akkor tehetünk meg, ha a mérések során megfelelő számú közös item szerepel az eltérő tesztekben, ezek a feladatok a horgony itemek. A kutatásunkban ennek megfelelően jártunk el, számos olyan feladat szerepel a negyedik évfolyamosoknak készített tesztben, ami megjelenik az ötödikesek és a hatodikosok tesztjében is, így indokolt alkalmaznunk a Rasch-modell által felkínált elönyöket. A mérőeszközök egymáshoz való viszonyát a 37. táblázat szemlélteti. Összesen 24 olyan item van, amelyik mindhárom évfolyam tesztjében is szerepel. 7 item a 4. és 5. évfolyamot köti össze, 20 item pedig az 5. és 6. évfolyam között teremt kapcsolatot. A szomszédos évfolyamok között további horgonyitemet iktattunk be. A mindhárom évfolyam által megoldott itemeket és a belölük képzett tesztet a 8.3.1. fejezetben itemenként elemezzük. 
37. táblázat A horgonyitemek száma és elhelyezkedése a vizuális kommunikációs képességet mérő tesztekben

\begin{tabular}{lcccc}
\hline \hline Részképesség & $\begin{array}{c}\text { Komponálás } \\
\text { síkban }\end{array}$ & Absztrakció & Szimbolizáció & Modalitásváltás \\
Évfolyam & & 15 & 1 & 8 \\
\hline \hline 4.,5.,6. évfolyam & 15 & 5 & 7 & \\
4.,5. évfolyam & & & & \\
5.,6. évfolyam & 15 & &
\end{tabular}

A valószínűségi tesztelmélet módszerével lefuttatott elemzés során kapott EAP/PV reliabilitás mutató értéke jó, 0,84. Az eredmények személy-item térképét a 23. ábrán találhatjuk. Az ábra bal oldalán lévő skála a feladatok nehézségét és a tanulók képességszintjét mutatja. Az x-ek a tanulókat jelentik, minden x 8,9 tanulót reprezentál. A jobb oldalon az itemek számát látjuk. Az ábrára tekintve megállapíthatjuk, hogy az itemek az átlagos és annál magasabb képességszinteket fedik le. Az IRT elemzés ábráján jól látható az is, hogy az itemek nehézsége kevésbé felel meg a minta képességszintjének, az itemek között sok a könnyü, az elemzések szempontjából kevésbé hasznos. Az itemek közül 23 (19\%) nem különbözteti meg a tanulókat, tehát nem várakozásaink szerint mér. 
23. ábra A teljes minta alapján készült szemény-item térkép 


\section{A vizuális kommunikációs képesség fejlődési tendenciái}

\section{1 Évfolyamok közötti különbségek, fejlődési tendenciák}

Megvizsgáljuk, hogy az egyes részmintákat képező évfolyamok közötti különbségek hogyan jelennek meg a teljesítményekben. A 38. táblázatban összegeztük az egyes évfolyamok teljesítményét. Minden évfolyamban előfordult olyan, aki nem ért el egy pontot sem a tesztkitöltés során. A variancia nalízis során a vizsgált évfolyamok között nem találtunk szignifikáns különbséget (Levene-teszt=0,35 p=0,7; F=0,11 p=0,89).

38. táblázat A teszten elért teljesitmény átlaga és szórása évfolyamonként.

\begin{tabular}{clcccc}
\hline \hline Évfolyam & N & Minimum & Maximum & Átlag (\%) & Szórás (\%) \\
\hline \hline 4. & & & & & \\
5. & 432 & 0 & 55 & 67,57 & 15,47 \\
6. & 338 & 0 & 63 & 67,11 & 14,77 \\
Teljes & 486 & 0 & 69 & 67,56 & 15,02 \\
\hline
\end{tabular}

A teljesítmények évfolyamonkénti gyakoriság eloszlása a 24. ábrán látható. Az eloszlások eltolódnak jobbra, a tesztek kevésbé mérnek a gyenge teljesítmények között. Különösen 6. évfolyamban bizonyult könnyünek a teszt.

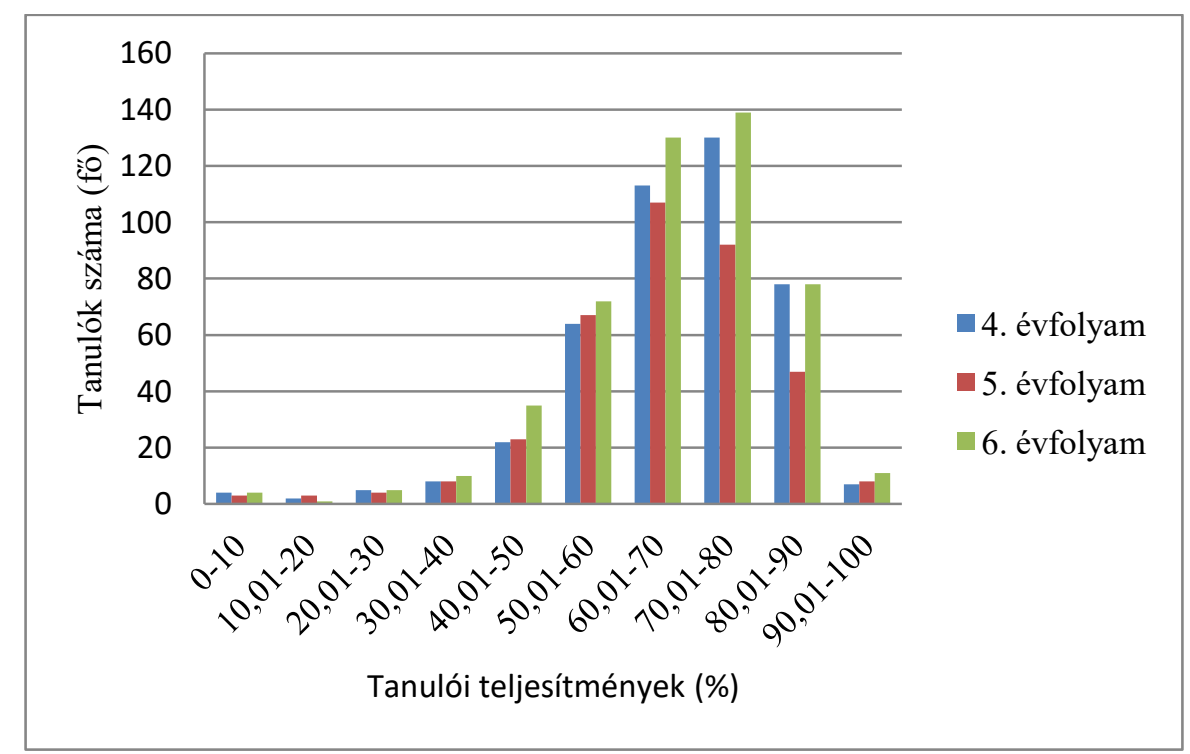

24. ábra A vizuális kommunikáció teszten elért teljesitmények gyakoriság eloszlása évfolyamonként

\subsection{Korosztályok közötti különbségek, fejlődési tendenciák}

Érdemes tovább bontani az évfolyamokat születési évek szerint, hiszen a vizuális képességek kétévente mutatnak ugrást a fejlődésben (Löwenfeld, 1970). Így hat csoportot különböztethetünk meg. A minta nagy részét a 2002-2005-ben születettek alkotják. A születési évekre bontott vizsgálat tovább árnyalja a képet és az átlagokban és a szórásban nagyobb különbségek fedezhetők fel az egyes korosztályok között (39. táblázat). A születési évekre bontott varianciaanalízissel végzett vizsgálat kimutat szignigikáns különbséget az egyes korosztályok között (Levene-teszt=3,63 $\mathrm{p}<0,05 ; \mathrm{F}=4,1 \mathrm{p}<0,05$ ). A születési évek teljesítményben jelentkező különbségének elemzése kapcsán megállapíthatjuk, hogy a különbség mértéke jelentős. 
39. táblázat A teszten elért teljesitmény átlaga és szórása születési évek szerint

\begin{tabular}{lccccc}
\hline Születési év & N & Minimum & Maximum & Átlag (\%) & Szórás (\%) \\
\hline \hline 2000 & 5 & 45,58 & 71,23 & 57,88 & 11,29 \\
2001 & 32 & 0 & 94,52 & 57,15 & 24,05 \\
2002 & 240 & 0 & 94,52 & 69,29 & 15,39 \\
2003 & 317 & 4,62 & 95,38 & 66,77 & 14,39 \\
2004 & 349 & 0 & 96,92 & 67,09 & 15,41 \\
2005 & 278 & 0 & 100 & 67,46 & 15,18 \\
\hline
\end{tabular}

A teszten elért teljesítmények nem mutatnak folyamatosan növekvő tendenciát a vizsgált korosztályokban (25. ábra). 2000-2001 és a 2002-2003 között tapasztalható némi visszaesés. Mivel a 2000-ben születettek mintája nagyon kevés elemszámú, a 2001-ben születtet tanulóktól érdemes vizsgálni a fejlődés ívét. Látványos fejlődési tendencia mutatkozik viszont a 2001-2002-ben születettek között $(\mathrm{t}=-3,88 \mathrm{p}<0,001)$. A teszt kitöltésének évében azok a gyerekek, akik nem vesztettek évet, a 4-6. évfolyamos populációt a 10-13 éves, azaz a 2002-2005 között születettek alkotják. Bár statisztikailag van köztük különbség, mégis a 2001-2002-ben születettek, az ún. túlkoros tanulók lemaradása észlelhető jobban. Mivel ez a korosztály kevesebb elemszámmal van jelen a mintában, általános következtetések levonásáshoz alaposabb vizsgálatokra van szükség.

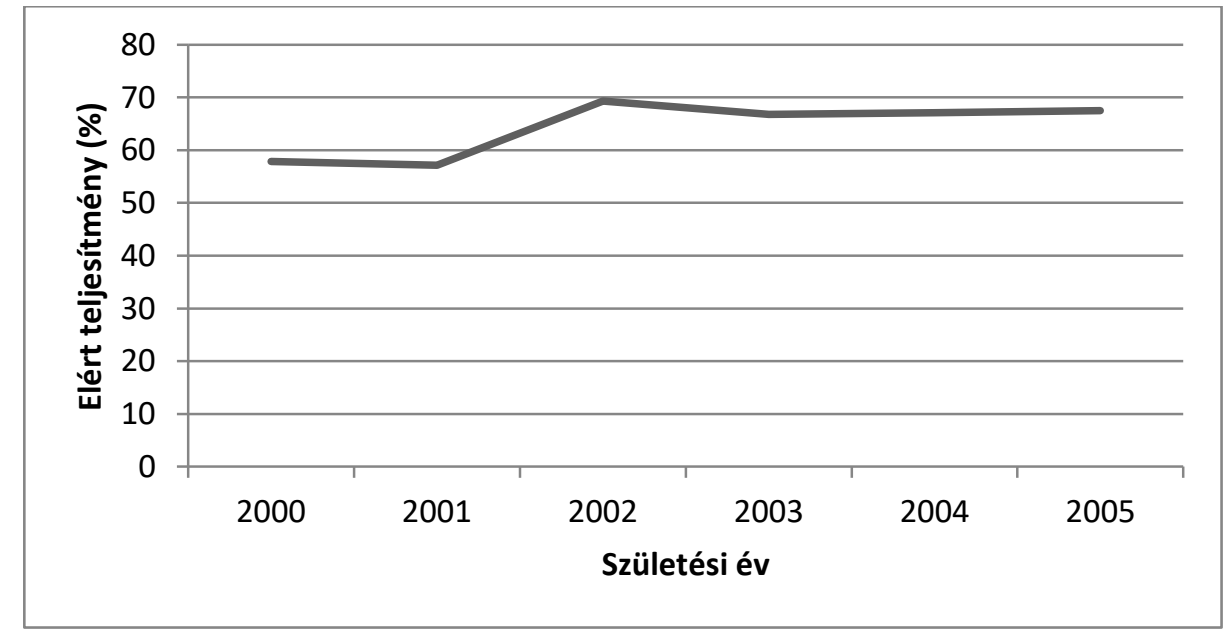

25. ábra A vizuális kommunikációs képesség fejlettsége a vizsgált korosztálybab

\subsection{A mindhárom évfolyamon megoldott horgonyitemek vizsgálata}

Ebben a részben a mindhárom évfolyam által megoldott itemek eredményeit megvizsgáljuk, mert feltételezzük, hogy árnyaltabb képet mutatnak a fejlődési tendenciákról. $\mathrm{Az}$ itemek megtalálhatók az 1. mellékletben. A mindhárom évfolyamon megoldott feladatokból képzett teszt 24 itemből áll, reliabilitása jó (Cronbach- $\alpha=0,75$ ). Az itemek megoldásainak vizsgálatát ANOVA elemzéssel végezzük, melynek során a független változó az évfolyam, illetve az életkor, függő változó az adott item. Mivel a 2000-ben születtek mintája kicsi elemszámú, célszerủ a feladatokhoz tartozó eredmények megfigyelése során a 2001-ben született tanulóktól kezdeni a fejlődés ívének vizsgálatát.

\subsubsection{Pontmozgása_456.}

A feladat egy itemböl áll. Egy vonalrajzot feleltetnek meg a tanulók egy szövegnek (26. ábra). A feladat absztrakt, erőteljes elvonatkoztatási képességet igényel. A feladat a vizuális értelmezés szintem az absztrakció részképességhez tartozik. A feladat megoldása függ attól is, 
hogy rendelkezik-e a tanuló olyan stratégiával, amivel képes folyó szöveghez képet társítani, illetve függ a szövegértés képességétöl.

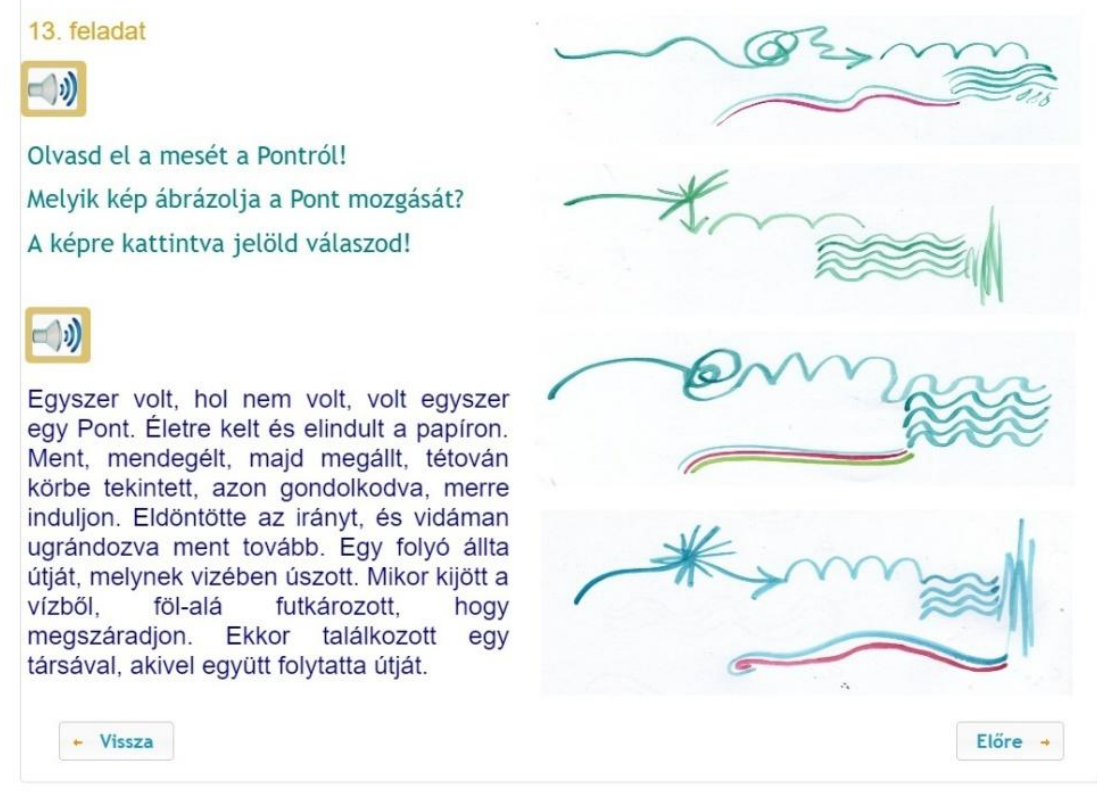

26. ábra A Pontmozgása_456 címü feladat szöveg és kép modalitására épül

Ebből adódóan, nem tudjuk, hogy azok a tanulók, akik rosszul oldották meg a feladatot, vajon a vizuális jeleket nem tudják értelmezni, vagy nem rendelkeznek azzal a stratégiával, amellyel ez a feladat megoldható. Erre irányulóan megvizsgáltuk a pontmozgása3_456 címü feladat eredményeivel a korrelációt, mely nagyon gyenge, de szignifikáns összefüggést mutat $(\mathrm{r}=0,16 \mathrm{p}<0,05)$. Ez azért fontos, mert pontmozgása3 456 című feladatban a vizuális jelek elnevezését közvetlenül a hiányos szövegben kell elhelyezni, így nem szükséges hozzá a fentebb említett stratégia. Ez azt sejteti, hogy nem a stratégia hiánya az elsődleges ok azokban az esetekben, mikor nem tudták a tanulók megoldani a feladatot. Az összetett absztrakt jelek olvasása bonyolult müvelet. További vizsgálatok szükségesek a következtetések levonásához. A pontmozgása_456 címü feladatban található jeleket és a leírást Paul Klee: Pedagógiai vázlatkönyv a gyermekrajzokban (Klee, 1980) címü könyvéből adaptáltuk. Az évfolyamokra bontott eredményeket a 40. táblázatban közöljük.

40. táblázat A Pont mozgása 2. címü feladat átlagai és szórásai

\begin{tabular}{lccc}
\hline & $\mathrm{N}$ & átlag & szórás \\
\hline \hline 4 & 429 & 0,38 & 0,49 \\
5 & 338 & 0,46 & 0,5 \\
6 & 485 & 0,39 & 0,49 \\
Teljes & 1252 & 0,4 & 0,49 \\
\hline
\end{tabular}

A feladat megoldásában nagy egyéni különbségek sejthetők, magas a szórás értéke, de az egyes évfolyamok átlagai között nincs szignifikáns különbség (Levene-teszt=6,63 p<0,05; $\mathrm{F}=2,54 \mathrm{p}=0,8)$. 
41. táblázat A pontmozgása_456. címü feladat átlagai és szórásai korosztályonként

\begin{tabular}{lcccccc}
\hline \hline & 2000 & 2001 & 2002 & 2003 & 2004 & 2005 \\
\hline \hline $\mathrm{N}$ & 5 & 32 & 240 & 317 & 349 & 277 \\
Átlag & 0,20 & 0,38 & 0,41 & 0,43 & 0,39 & 0,42 \\
Szórás & 0,45 & 0,49 & 0,49 & 0,5 & 0,49 & 0,49 \\
\hline
\end{tabular}

Amennyiben születési évekre bontva is megvizsgáljuk az eredményeket, az évfolyamszintü elemzéshez hasonló következtetést vonhatunk le. (Levene-teszt=4,31 p<0,05, $\mathrm{F}=0,47 \mathrm{p}=0,8)$. Figyelemre méltó mégis a 27 . ábra, melyen világosan látszik, hogy a fiatalabb korosztályok jobb teljesítményt értek el a feladat megoldásában.

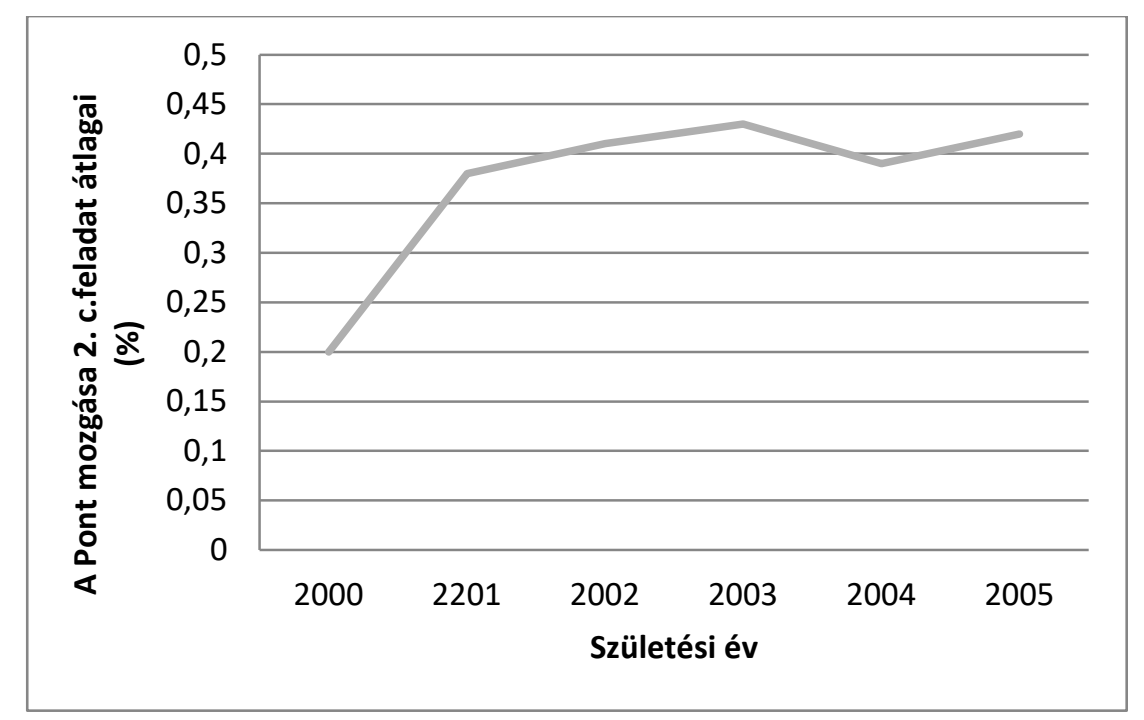

27. ábra A Pont mozgása 2. cimü feladat átlagain és a születési évek közötti összefüggés

\subsubsection{Pontmozgása3 456.}

A feladatban absztrakt ábrákhoz kell megkeresni a hozzá tartozó, szövegbe illesztett szót. A feladat a vizuális értelmezés szinten az, absztrakció részképességhez tartozik (28. ábra). A feladat öt itemböl áll, itemenként 1-1 pontot lehetett kapni (Cronbach- $\alpha=0,73$ ). Ezt a feladatot tekintve a minta egyéni és évfolyamok között is homogén (Levene-teszt $=0,4 \mathrm{p}=$, $067 ; \mathrm{F}=0,96 \mathrm{p}=0,39)$ (42. táblázat). 


\section{8. feladat}

๑) P) Párosítsd a rajzokat a szövegben jelölt kifejezésekkel! Válaszd ki a kifejezések utáni legördülő listából a megfelelő ábra betűjelét!

گ̌Minden ábrához csak egy meghatározás tartozik és egy ábrának nincs párja.

D) Egyszer volt, hol nem volt, volt egyszer egy Pont. Életre kelt és elindult a papíron. Ment. mendegélt. Válassz! • majd megállt, tétován körbe tekintett Válassz! • azon gondolkodva, merre induljon. Eldöntötte $a z$ irányt Válassz! • és vidáman ugrándozva ment Válassz! v tovább. Egy folyó állta útját, melynek vizében úszott. Mikor kijött a vízböl, föl-alá futkározott, hogy megszáradjon. Ekkor találkozott egy társával, akivel együtt folytatta útját Válassz! •

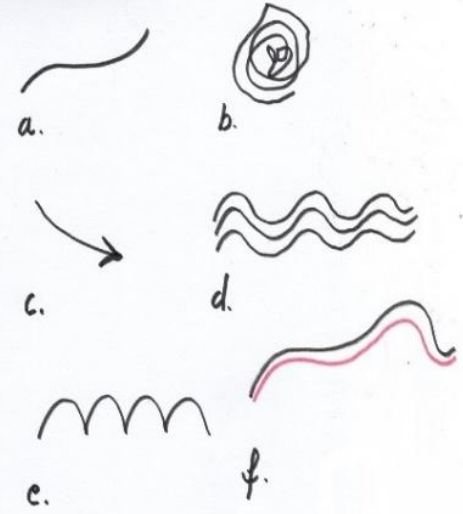

28. ábra A Pontmozgása3_456 címü feladat

42. táblázat A Pont mozgása 3. címü feladat átlagai és szórásai évfolyamonként

\begin{tabular}{lccc}
\hline \hline & $\mathrm{N}$ & átlag & szórás \\
\hline \hline 4 & 425 & 2,29 & 1,41 \\
5 & 336 & 2,42 & 1,42 \\
6 & 484 & 2,31 & 1,43 \\
Teljes & 1245 & 2,34 & 1,42 \\
\hline
\end{tabular}

Hasonló eredményre jutunk, ha születési évek szerint bontjuk a mintát. Nincs szignifikáns különbség sem a szórás, sem az átlagok között (Levene-teszt=0,21 p=0,96; $\mathrm{F}=2,02 \mathrm{p} \mathrm{p}=0,07)$ (43. táblázat).

43. táblázat A Pont mozgása 3. címü feladat átlagai és szórásai születési évek szerint

\begin{tabular}{lcccccc}
\hline \hline & 2000 & 2001 & 2002 & 2003 & 2004 & 2005 \\
\hline \hline $\mathrm{N}$ & 5 & 32 & 240 & 317 & 349 & 277 \\
Átlag & 2,2 & 1,78 & 2,51 & 2,29 & 1,42 & 1,42 \\
Szórás & 1,64 & 1,48 & 1,40 & 1,42 & 1,42 & 1,42 \\
\hline
\end{tabular}




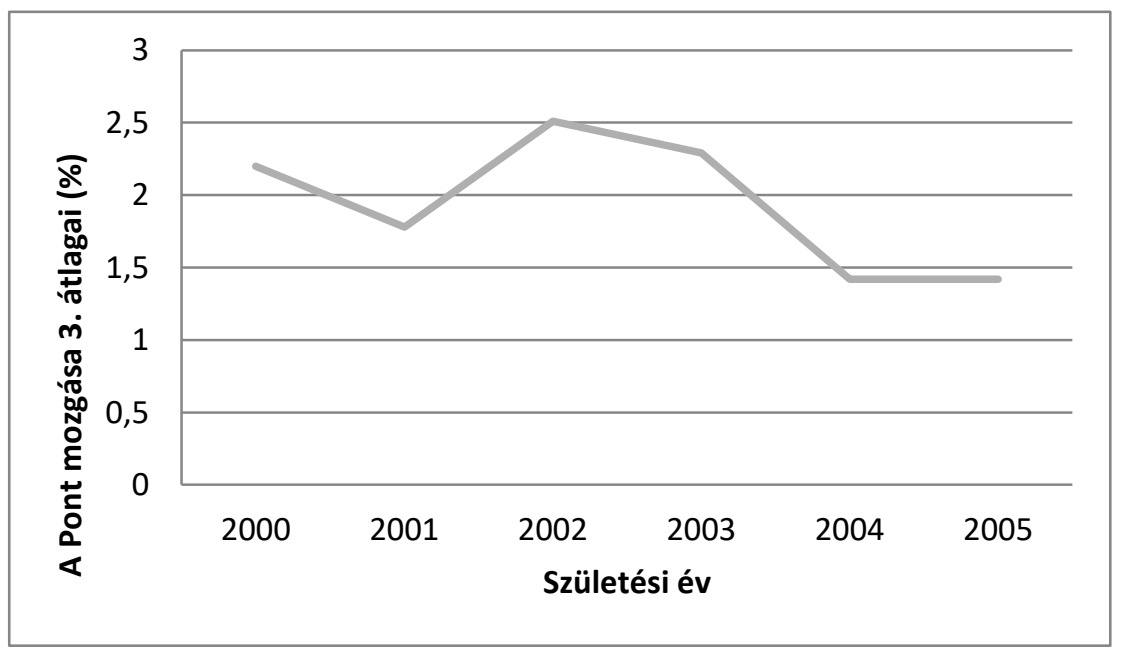

29. ábra A Pont mozgása 3. címü feladat átlagain és a születési évek közötti összefüggés

\subsubsection{Piktogramfurulya_456}

A feladat egy itemből áll, négy lehetőség közül választhattak a tanulók. Egyetlen megoldást fogadtunk el. A feladatban elérhető maximális pontszám 1. A feladat a vizuális értelmezés szinten a szimbolizáció részképességhez tartozik (30. ábra).

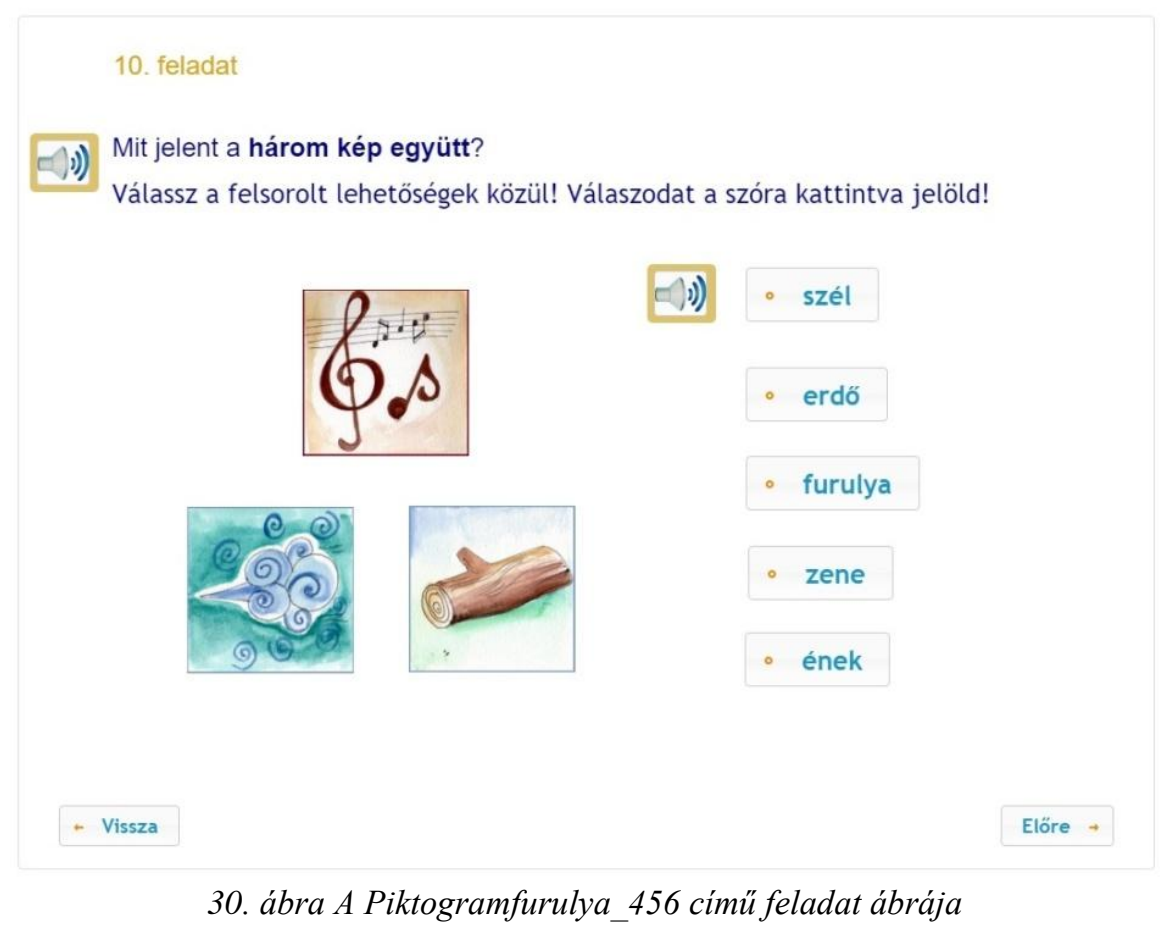

A 44. táblázatban közöljük az egyes évfolyamokon az átlag és szórás különbségeket. Az ötödik évfolyamosok nyújtották a legrosszabb, a negyedikesek a legjobb teljesítményt, de nincs szignifikáns különbség az egyes évfolyamok között (Levene-teszt=3,09 p=0,04, F=2,06 $\mathrm{p}=0,13)$. 
44. táblázat A Pikotgram címü feladat eredményei évfolyamokra bontva

\begin{tabular}{lccc}
\hline \hline & $\mathrm{N}$ & átlag & szórás \\
\hline \hline 4 & 429 & 0,55 & 0,49 \\
5 & 338 & 0,48 & 0,5 \\
6 & 485 & 0,51 & 0,5 \\
Teljes & 1252 & 0,52 & 0,5 \\
\hline
\end{tabular}

Amennyiben a feladatban nyújtott teljesítményt születési évekre lebontva vizsgáljuk árnyaltabb képet kapunk (45. táblázat). A hat korosztály szórása szignifikánsan különbözik egymástól (Levene-teszt $=19,47 \mathrm{p}=0,00)$. A varianciaanalízis $(\mathrm{F}=1,12 \mathrm{p}=0,35)$ Dunett post hoc elemzése alapján a 2000-ben születetteket kivéve, az egyes korosztályok között nem szignifikáns a különbség.

45. táblázat A Piktogram-furulya címü feladat átlagai és szórásai születési évek szerint

\begin{tabular}{lcccccc}
\hline \hline & 2000 & 2001 & 2002 & 2003 & 2004 & 2005 \\
\hline \hline $\mathrm{N}$ & 5 & 32 & 240 & 317 & 349 & 277 \\
Átlag & 0,20 & 0,41 & 0,50 & 0,51 & 0,54 & 0,55 \\
Szórás & 0,58 & 0,49 & 0,50 & 0,50 & 0,49 & 0,49 \\
\hline
\end{tabular}

Ez a különbség egyértelműen látható a 31. ábrán, melyen feltűnő az a tendencia, hogy a később születettek, azaz a fiatalabbak jobb teljesítmény nyújtottak. A különbség nem elhanyagolható.

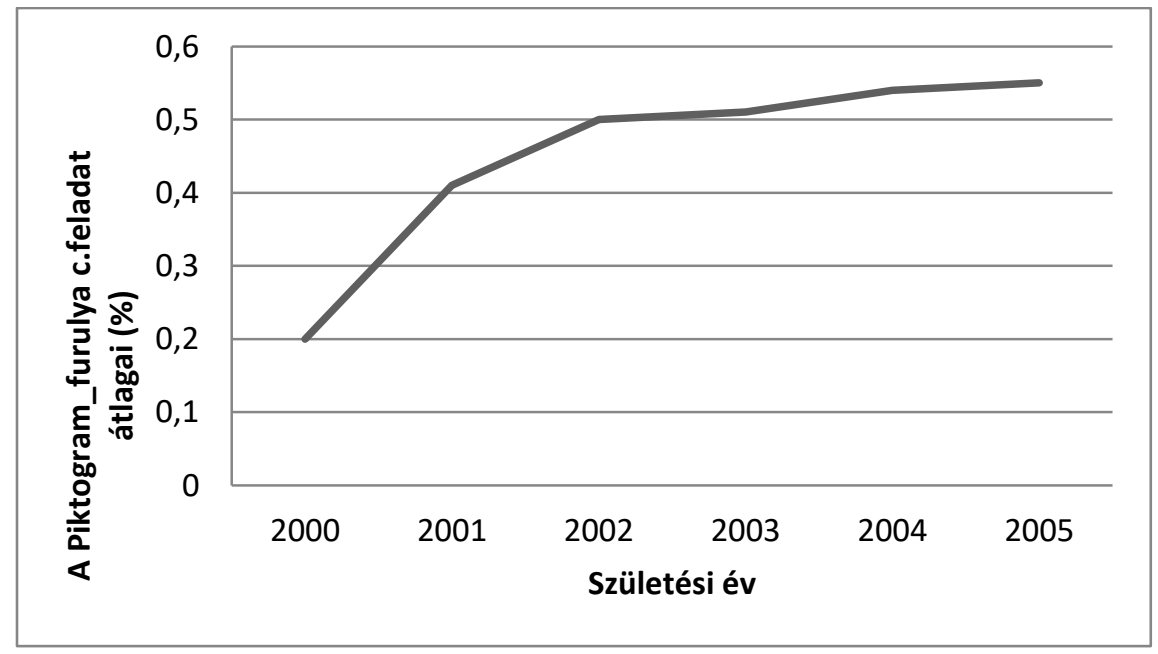

31. ábra A Piktogram_furulya címü feladat átlagain és a születési évek közötti összefüggés

\subsubsection{Zene1_456}

A feladat 4 itemből áll, itemenként 1-1 pontot szerezhettek a tanulók (13. ábra). A feladatban az auditív és vizuális ingereket kell megfeleltetni egymásnak, különböző modalitásokat kell összekapcsolni. A feladat a vizuális értelmezés szinten a modalitásváltás részképességhez tartozik. Korábbi vizuális képességtesztekben nem szerepelt hasonló feladat, ezért új feladatot dolgoztunk ki. Az egyszerü, sematikus vonalrajzokat kellett a tanulóknak párosítani a harsonán játszott egy szólamú zenei részlettel. A feladat megbízhatósága jó (Cronbach- $\alpha=0,65$ ) (46. táblázat). A teljes feladat Dunett $C$ post hoc elemzése alapján a 4. és 6. évfolyam átlagai között van szignifikáns különbség (Leven teszt $=3,53 \mathrm{p}=0,03 ; \mathrm{F}=4,04$ $\mathrm{p}=0,02)$. 
46. táblázat A Zenel feladat szórásai ás átlagai évfolyamok szerinti bontásban.

\begin{tabular}{lccc}
\hline & $\mathrm{N}$ & átlag & szórás \\
\hline \hline 4 & 430 & 1,73 & 1,32 \\
5 & 332 & 2,00 & 1,45 \\
6 & 484 & 1,85 & 1,38 \\
Teljes & 1246 & 1,85 & 1,38 \\
\hline
\end{tabular}

Ha korosztályonként bontjuk az itemeket kitöltők teljesítményét, a szórás nem különbözik jelentősen, ugyanakkor a 32. ábrán is látható, hogy az egyes korosztályok között különbségek vannak (Leven-teszt=2,6 p=0,94; $\mathrm{F}=4,63 \mathrm{p}<0,05$ ). Amennyiben eltekintünk az ún. túlkoros tanulóktól, az eredmények egyre rosszabbak a fiatalabb tanulók irányában.

47. táblázat A Zenel feladat szórásai ás átlagai születési évek szerinti bontásban.

\begin{tabular}{lcccccc}
\hline \hline & 2000 & 2001 & 2002 & 2003 & 2004 & 2005 \\
\hline \hline $\mathrm{N}$ & 5 & 32 & 239 & 316 & 346 & 276 \\
Átlag & 2,4 & 1,81 & 2,1 & 1,91 & 1,85 & 1,54 \\
Szórás & 1,67 & 1,42 & 1,41 & 1,39 & 1,37 & 1,31 \\
\hline
\end{tabular}

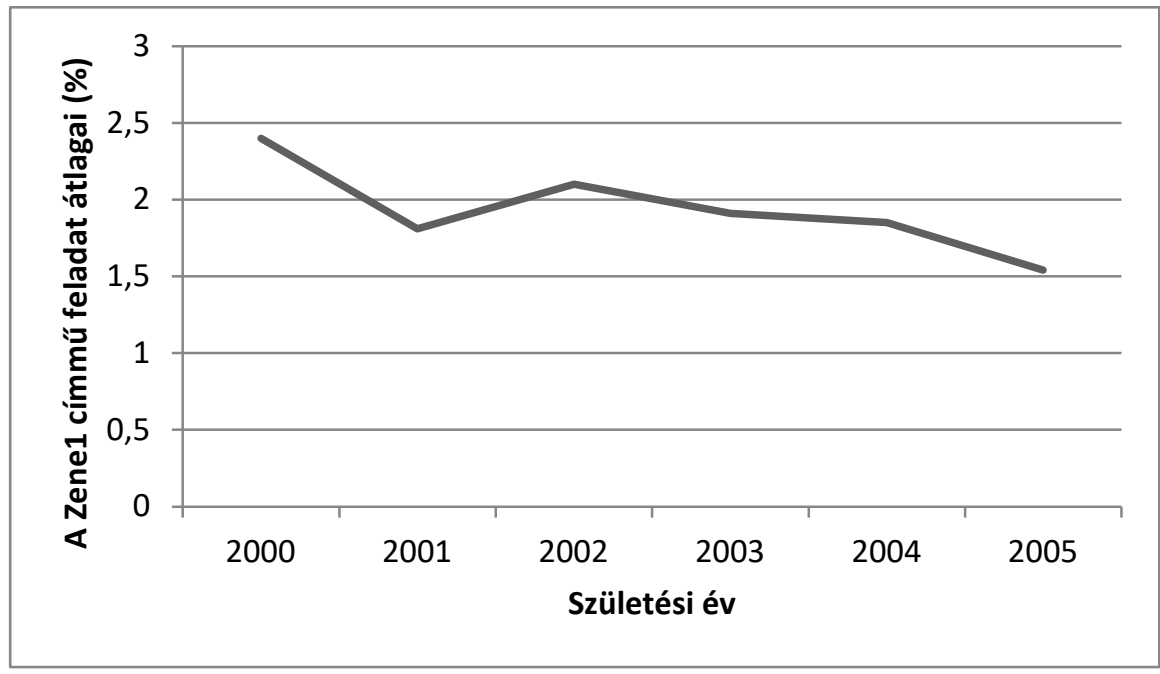

32. ábra A Zene1 feladat átlagain és a születési évek közötti összefüggés

\subsubsection{Zene2_456}

A Zene2 feladat hasonlóan a Zene1 címü feladathoz auditív és vizuális ingerek párosítására épül. Szintén 4 itemes a feladat. Ez a feladat nehezebb az előzőnél, amennyiben egy-egy ábrán két különböző színü vonalrajz van, melyet harsonán és zongorán elöadott kétszólamú zenei részlettel kell összekapcsolni. A feladat a vizuális értelmezés szinten a modalitásváltás részképességhez tartozik (33. ábra). 


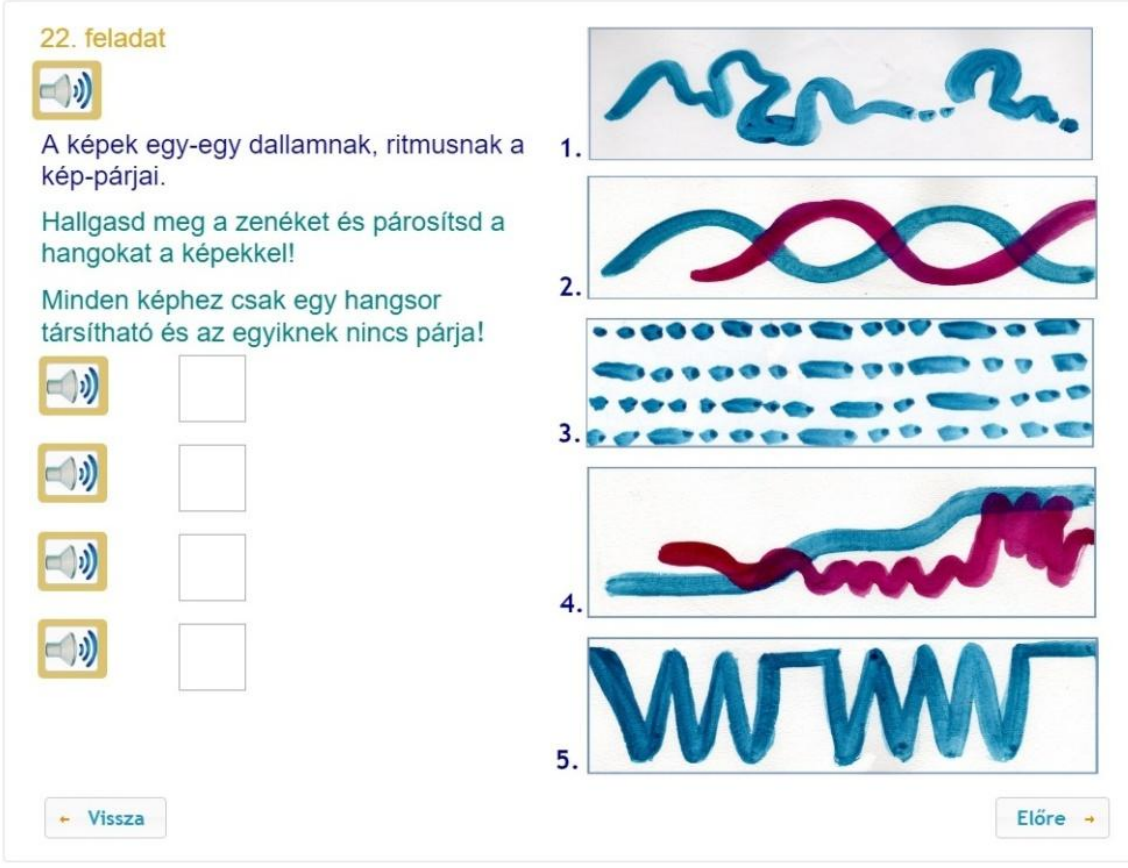

33. ábra A Zene2_456 címü feladat ábrája

A feladat megbízhatósága alacsonyabb, mint a Zene1_456 feladaté, de elfogadható (Cronbach- $\alpha=0,63$ ) (48. táblázat). A varianciaanílis Tukey's-b post hoc elemzése az 5. és 6 . évfolyamot különíti el szignifikánsan (Levene-teszt=0,82 p=0,44; F=3,24 p=0,04).

48. táblázat A Zene2 feladat szórásai ás átlagai évfolyamok szerinti bontásban.

\begin{tabular}{lccc}
\hline & $\mathrm{N}$ & átlag & szórás \\
\hline \hline 4 & 430 & 1,768 & 1,30 \\
5 & 333 & 1,57 & 1,36 \\
6 & 482 & 1,81 & 1,35 \\
Teljes & 1245 & 1,70 & 1,35 \\
\hline
\end{tabular}

Születési évekre bontva hasonlóan a másik hang-kép modalitásváltásra épülő feladathoz a 2000 és a 2002-ben születtettek eredményei ugranak ki (Levene-teszt $=1,07 \mathrm{p}=0,38 ; \mathrm{F}=3,81$ $\mathrm{p}<0,05)$ (34. ábra).

49. táblázat A Zene2 feladat szórásai ás átlagai születési évek szerinti bontásban.

\begin{tabular}{lcccccc}
\hline \hline & 2000 & 2001 & 2002 & 2003 & 2004 & 2005 \\
\hline \hline $\mathrm{N}$ & 5 & 32 & 239 & 314 & 346 & 277 \\
Átlag & 2,2 & 1,69 & 2,0 & 1,69 & 1,64 & 1,52 \\
Szórás & 0,84 & 1,49 & 1,38 & 1,37 & 1,32 & 1,27 \\
\hline
\end{tabular}




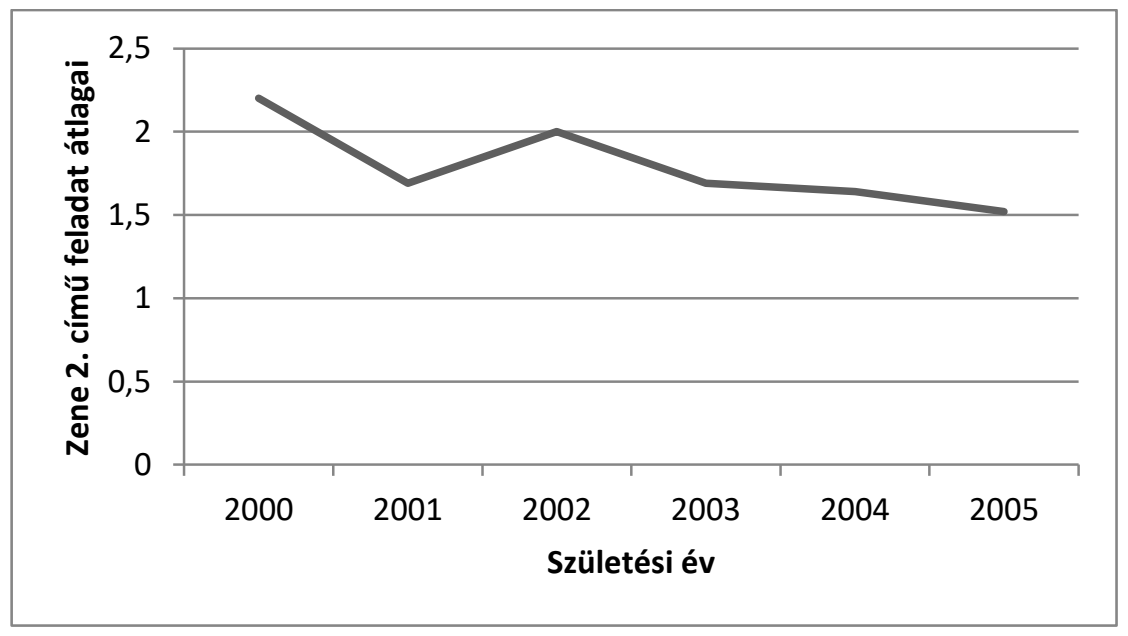

34. ábra A Zene 2. címü feladat átlagai és a születési évek közötti összefüggés

\subsubsection{Terkep_456}

A térkép címü feladat azért került be mindhárom évfolyam tesztjébe, mert a térképek értelmezése fontos része a vizuális kommunikációnak. A hatodikosok tesztjében ezen kívül még két térképet értelmező feladat van. Ez a térképet ábrázoló feladat mesei elemeket tartalmazó kalóztérkép, melyen útvonalakat jelültünk be (35. ábra). A tanulóknak a térképről szóló állítások igazságát kellett eldönteni.

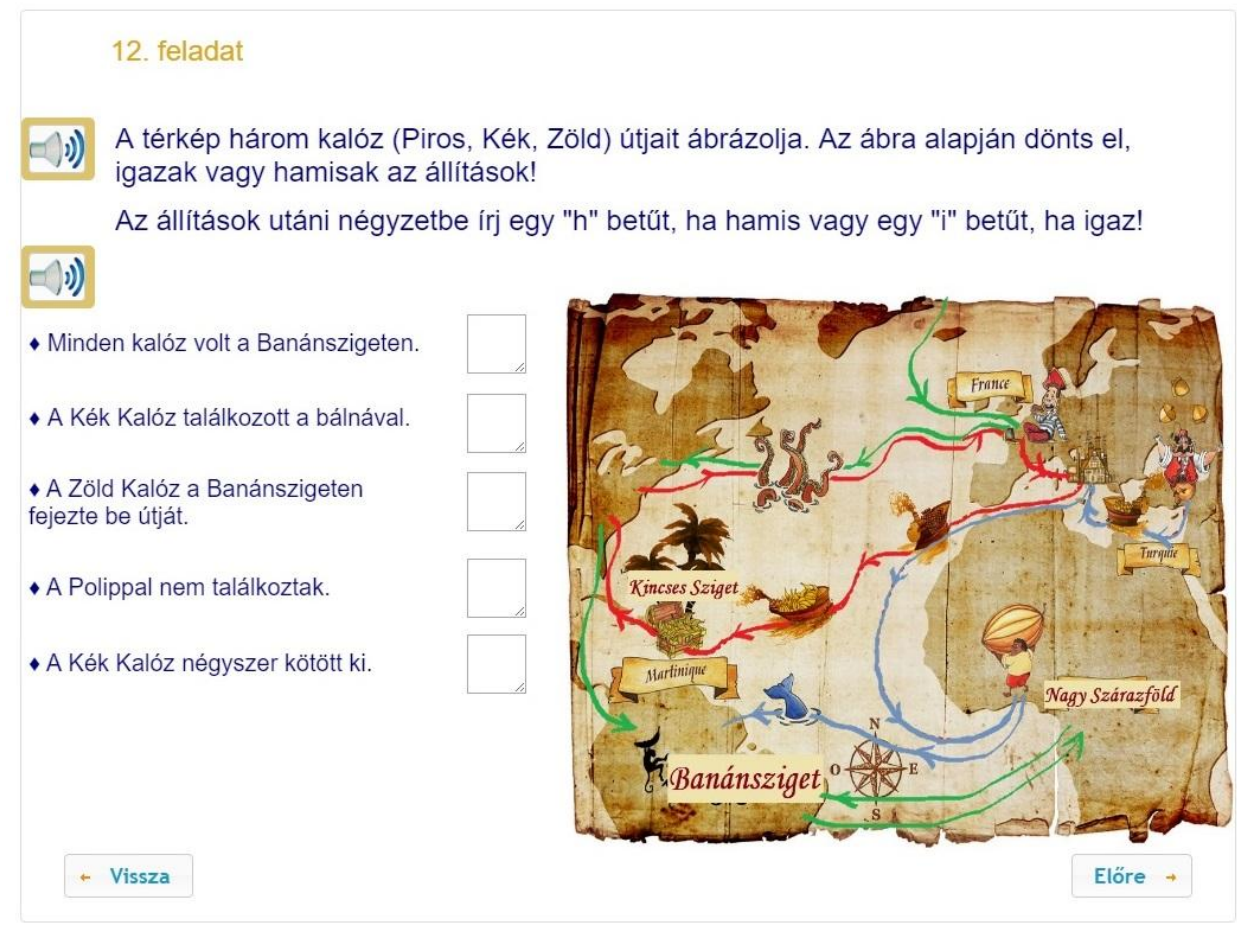

35. ábra A Terkep_456 címü feladat ábrája

A feladat 5 itemből áll, itemenként 1-1 pontot kaphattak a tanulók (Cronbach- $\alpha=0,59)$ (50. táblázat). Az egyes évfolyamokon belül és az évfolyamok között sincs szignifikáns különbség a teljesítmények között (Levene-teszt=2,39 p=0,09, F=1,98p=0,14). 
50. táblázat A Térkép címü feladat átlagai és szórásai évfolyamonként

\begin{tabular}{lccc}
\hline \hline & $\mathrm{N}$ & átlag & szórás \\
\hline \hline 4 & 430 & 3,56 & 1,33 \\
5 & 338 & 3,74 & 1,17 \\
6 & 481 & 3,69 & 1,32 \\
Teljes & 1249 & 3,66 & 1,29 \\
\hline
\end{tabular}

Ha születési évek szerint bonjuk a mintát a 2001-ben születtettek kivételével nincs szignifikáns különbség az egyes korcsoportok között. Bár a feladat megoldásában szignifikánsak az egyéni különbségek, de az egyes korosztályok nem különülnek el. (Levene_teszt=3,69 p <0,05; F=2,22 p=0,05) (36. ábra).

51. táblázat A Térkép címü feladat szórásai ás átlagai születési évek szerinti bontásban.

\begin{tabular}{lcccccc}
\hline \hline & 2000 & 2001 & 2002 & 2003 & 2004 & 2005 \\
\hline \hline $\mathrm{N}$ & 5 & 32 & 239 & 314 & 349 & 278 \\
Átlag & 3,8 & 2,97 & 3,7 & 3,64 & 3,72 & 3,59 \\
Szórás & 1,67 & 1,42 & 1,41 & 1,39 & 1,37 & 1,31 \\
\hline
\end{tabular}

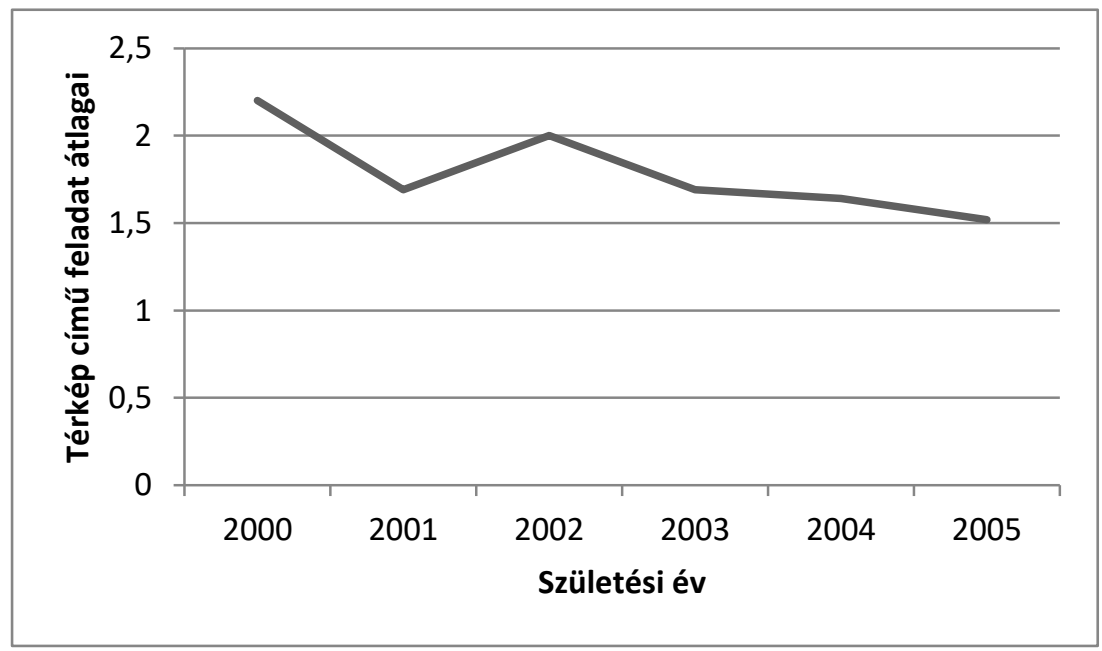

36. ábra A Térkép címü feladat átlagai és a születési évek közötti összefüggés

\subsubsection{A horgony itemekből álló teszt vizsgálata}

A horgonyitemekből összefüzött tesztet minden tanuló kitöltötte, 24 itemből áll (Cronbach- $\alpha=0,78$ ). Évfolyamonként vizsgálva a tesztet nincs szignifikáns különbség az egyes évfolyamok átlagai között $(\mathrm{F}=2,29 \mathrm{p}=0,10)$ (52. táblázat). Ugyanakkor, ha korosztályokra bontjuk az eredményeket, már kimutatható a különbség a különböző évben születettek között (Levene_teszt=2,87 $\mathrm{p}<0,05 \quad \mathrm{~F}=4,15 \quad \mathrm{p}<0,05) \quad$ (53. táblázat). A varianciaanalízis Dunett C post hoc elemzése alapján a 2001-ben születettek teljesítettek kiugróan különbözően a többiektől. A horgony itemekből képzett teszt eredménye is megerősítette azt, hogy az évfolyamok között nem mutatkozik szignifikáns különbség, de a korosztályok között már kimutatható fejlődési tendencia, de nem jelentős.

Ez a minimális fejlődés spontán érés eredménye is lehet. Ugyanakkor, az iskolák között jelentős különbségek mutatkoznak, ez feltételezi, hogy a tanári munka hatása eltérő $(9.1$. fejezet). Mivel a rajztanítás hatékonyságának vizsgálata nem szerepelt vizsgálataink céljai között, erre vonatkozóan több adattal nem rendelkezünk, következtetést nem vonunk le.

A teszt itemenkénti vizsgálata nem szolgáltatott plusz információt arra vonatkozóan, hogy milyen típusú vagy tartalmú itemek felelnek meg az egyes évfolyamoknak, illetve 
korosztályoknak. Ekkora itemszámból még nem vonható le egyértelmü következtetés. Két feladatban jobban teljesítettek a fiatalabbak: pontmozgása_456 és piktogramfurulya_456. Mindkét feladat egy-egy itemet tartalmaz. A két feladat abban hasonlít egymáshoz, hogy megoldásuk holisztikusabb szemléletet, szintetizáló gondolkodást igényel.

A mindhárom évfolyam által megoldott itemek elemzése valamint a teszteredmények alapján megállapíthatjuk, hogy nincsenek egyértelmü tendenciák a vizsgált évfolyamokon, ami arra enged következtetni, hogy a kognitív érés nem jár együtt automatikusan a vizuális kommunikációs képesség fejlődésével. Ez felhívja a figyelmünket a vizuális kommunikációs képesség tudatos fejlesztésének szükségére.

52. táblázat A horgonitemekböl képzett teszt szórásai ás átlagai évfolyam szerinti bontásban.

\begin{tabular}{lccc}
\hline & $\mathrm{N}$ & átlag & szórás \\
\hline \hline 4 & 427 & 13,85 & 4,54 \\
5 & 331 & 14,20 & 4,45 \\
6 & 482 & 14,48 & 4,46 \\
Teljes & 1240 & 14,19 & 4,49 \\
\hline
\end{tabular}

53. táblázat A horgonyitemekböl képzett teszt szórásai ás átlagai születési évek szerinti bontásban.

\begin{tabular}{lcccccc}
\hline \hline & 2000 & 2001 & 2002 & 2003 & 2004 & 2005 \\
\hline \hline $\mathrm{N}$ & 5 & 32 & 238 & 314 & 344 & 272 \\
Átlag & 14,80 & 12,03 & 15,06 & 14,23 & 14,27 & 13,53 \\
Szórás & 3,90 & 6,13 & 4,68 & 4,17 & 4,31 & 4,61 \\
\hline
\end{tabular}

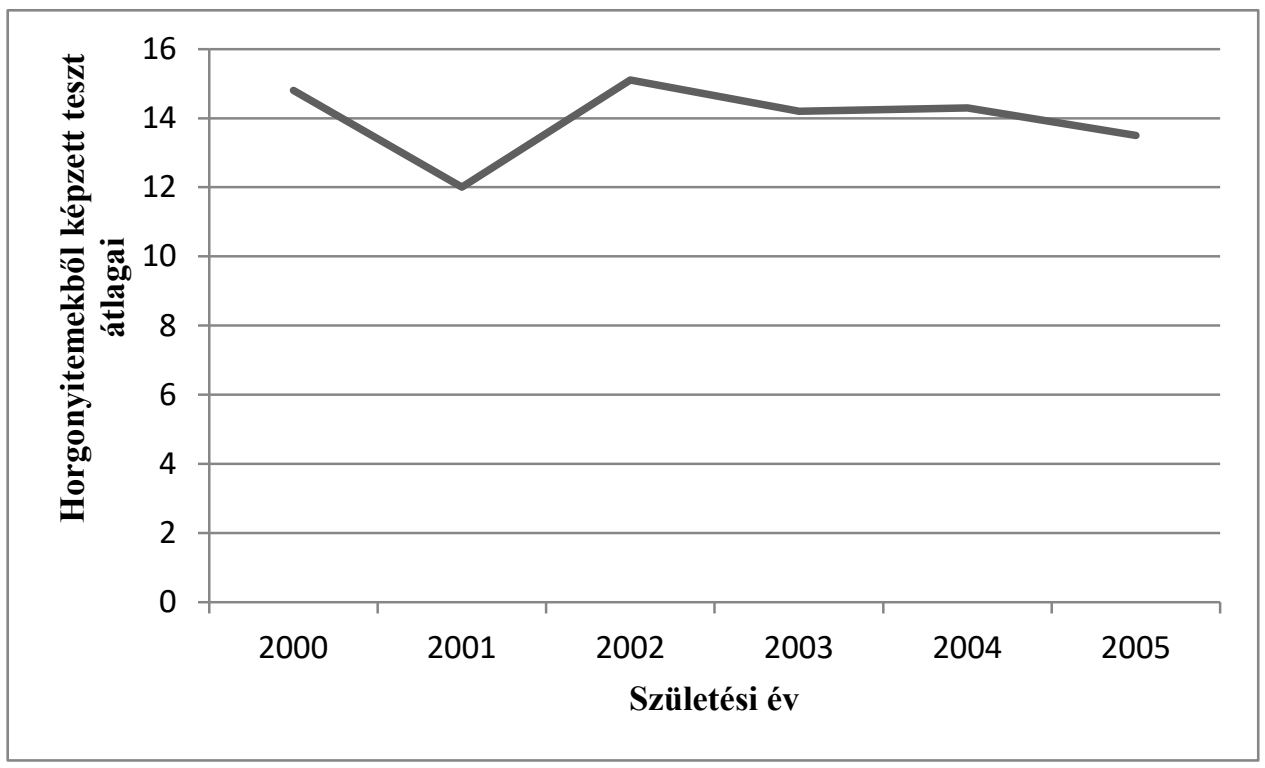

37. ábra A horgonyitemekböl képezett teszt átlagai és a születési évek közötti összefüggés 


\section{A vizuális kommunikáció teszten elért teljesítmény összefüggései a háttérváltozókkal}

A teszten elért eredményeket számos háttérváltozó befolyásolhatja (7.3.4. fejezet). Ezekről a teszt kitöltése mellett kérdőíves formában információkat gyüjtöttünk. A továbbiakban ezek közül az iskolák, a nemek szerinti különbségeket vizsgáljuk, illetve a családi háttérváltozók, valamint a számítógép-és internethasználat és a vizuális kommunikáció teszten elért teljesítmények kapcsolatát közöljük.

\subsection{Az iskolák közötti különbségek}

Az egyes intézményeken között szignifikáns különbséget mutatott ki a varianciaanalízis (Levene-teszt $=2,07 \mathrm{p}=0,02 ; \mathrm{F}=5,22 \mathrm{p}<0,001)$. Ez megerősíti a magyar közoktatás szélsőséges egyenlőtlenségi tendenciáiról szóló beszámolókat (Balázsi és tsai. 2005, 2007; Csapó, Molnár és Kinyó, 2009). Amennyiben a vizuális kommunikáció teszten elért teljesítmény alapján állítunk rangsort a régiók között, észlelhető nem csak az intézmények közötti különbség, hanem az egyes régiók közötti különbségek is. A Közép-Magyarország régió intézményei (4 település) értek el legjobb eredmény a teszteken. Hiba lenne ebből következtetést levonni, hiszen nem reprezentatív mintavétel történt. Dél-Alföld kimagasló teljesítményét például egyetlen intézmény adja. Ugyanakkor a szórások és átlagok szignifikáns különbsége mindenképp jelzés lehet egy tendenciára, de állítások kijelentéséhez további kutatások szükségesek.

\subsection{Nemek szerinti különbségek}

A nemek közötti különbségeket elöször évfolyamonként vizsgáltuk meg. Ha minden kitöltésben résztvevő tanuló teszten elért teljesítményét figyelembe vesszük, a korreláció rendkívül alacsony $(\mathrm{r}=0,013 \mathrm{p}<0,01)$. A teszteredmény évfolyamonként és nemek szerinti elemzését t-próbával is elvégeztük. A három részminta között nem találtunk szignifikáns különbséget. A nemek közti különbségeket megvizsgálva megállapíthatjuk, hogy elhanyagolható különbség van a lányok és a fiúk teszten nyújtott teljesítménye között (54. táblázat),

54. táblázat A vizuális kommunikáció teszt eredményei nemek szerinti bontásban

\begin{tabular}{|c|c|c|c|c|c|c|c|c|}
\hline \multirow[b]{2}{*}{ korcsoport } & \multicolumn{2}{|c|}{ Átlag (\%) } & \multicolumn{2}{|c|}{ Szórás (\%) } & \multicolumn{2}{|c|}{ Levene-teszt } & \multicolumn{2}{|c|}{ t-próba } \\
\hline & fiú & lány & fiú & lány & $\mathrm{F}$ & $\mathrm{p}$ & $\mathrm{t}$ & $\mathrm{p}$ \\
\hline 4. & 66,71 & 68,71 & 15,00 & 15,94 & 0,24 & 0,63 & $-1,19$ & 0,23 \\
\hline 5. & 67,17 & 67,05 & 14,06 & 15,46 & 0,45 & 0,5 & 0,07 & 0,94 \\
\hline 6. & 67,55 & 67,57 & 14,98 & 15,09 & 0,09 & 0,76 & $-0,02$ & 0,99 \\
\hline Teljes & 67,16 & 67,73 & 14,73 & 15,46 & 0,75 & 0,39 & $-0,68$ & 0,5 \\
\hline
\end{tabular}

\subsection{A vizuális kommunikáció teszten elért teljesítmény az osztályzatok és az attitüdök tükrében}

Az egyes évfolyamok tantárgyi átlagait a 55. táblázatban összegeztük. Látható, hogy bár az évfolyam növekedésével az átlagok egyre kisebbek, de még a 6. évfolyamon is 4 egész felett van az összesített tantárgyi átlag. 


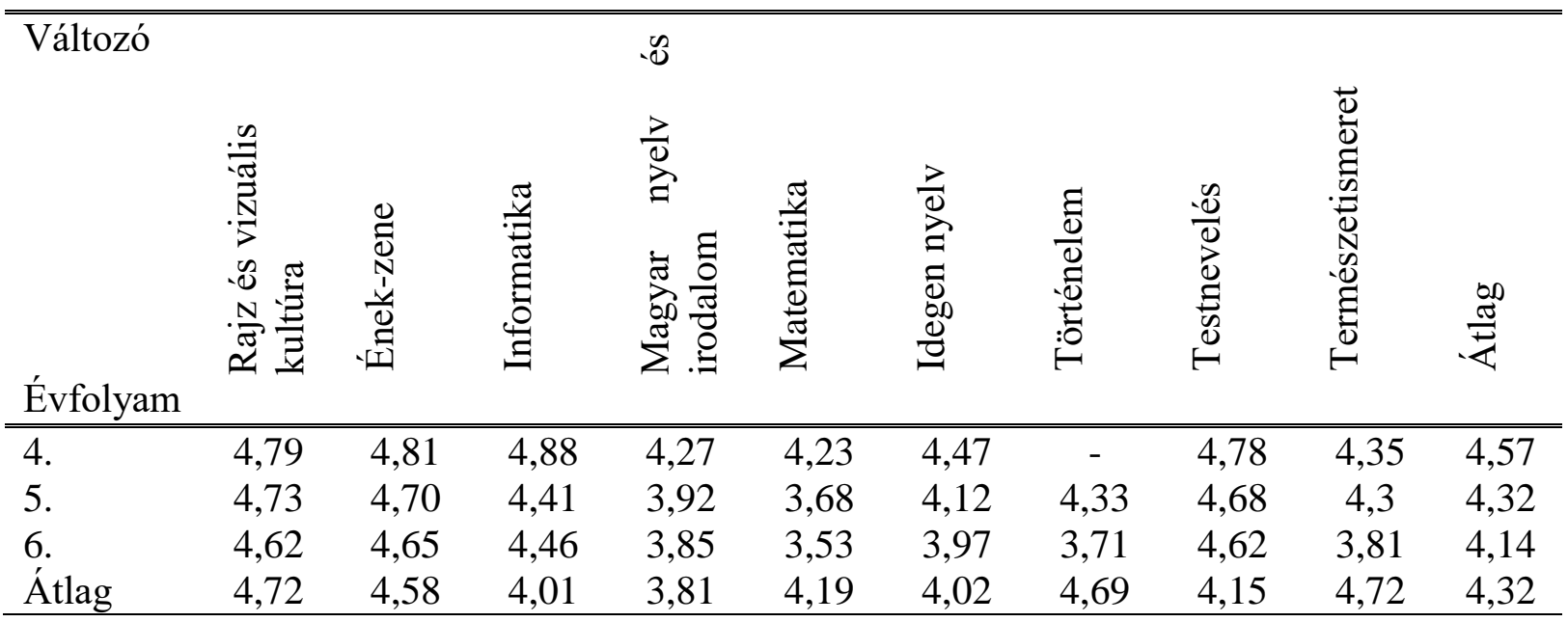

A vizuális kommunikáció teszt eredményei és az osztályzatok közötti kapcsolatrendszer vizsgálva látható, hogy az összefüggés minden esetben szignifikáns (56. táblázat). A korrelációs együtthatók 0,17 és 0,41 között mozognak. Az összevont tanulmányi átlag változóval a korreláció közepes erősségü $(\mathrm{r}=0,48 ; \mathrm{r}=0,46 ; \mathrm{r}=0,46)$. A legszorosabb kapcsolat a matematika és a magyar nyelv és irodalom osztályzatok esetében figyelhető meg. Ez érthető, hiszen számos feladatban a szövegértés képessége és a feladatmegoldó képesség is szerepet játszhat a teszten elért eredmény alakulásában.

A rajz és vizuális kultúrával való összefüggés mindhárom évfolyamon gyenge, ami arra enged következtetni, hogy a vizuális kommunikáció befogadó képességei nem a rajz órákon fejlődnek elsősorban. Ugyanakkor a tantárgyi osztályzatokkal való szignifikáns összefüggések felhívják a figyelmünket a vizuális képességek jelentőségére a kognitív területeken. A transzferhatás vizsgálata nem tartozott céljainkhoz és feltárásához összetett vizsgálat szükséges, mégis az adatok utalhatnak jelenlétére. táblázata

56. táblázat A vizuális kommunikáció teszten elért eredmények és az osztályzatok közötti korrelációk

\begin{tabular}{|c|c|c|c|c|c|c|c|c|c|}
\hline Változó & 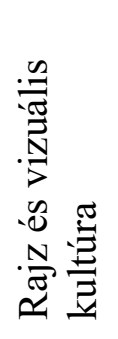 & 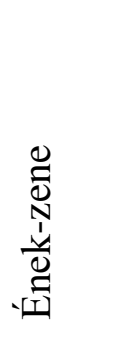 & 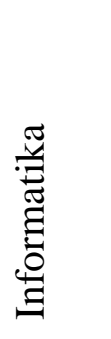 & 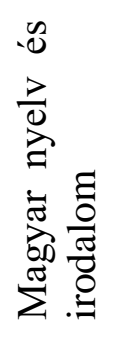 & 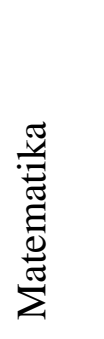 & 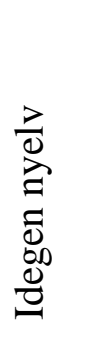 & 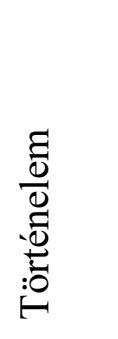 & 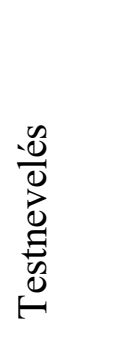 & 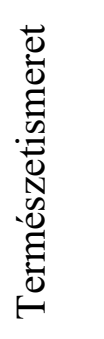 \\
\hline 4.évfolyar & 0,26 & 0,20 & 0,20 & $\overline{0.41}$ & 0,37 & 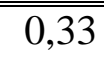 & - & 0,23 & 0,39 \\
\hline 5.évfolyam & 0,20 & 0,23 & 0,35 & 0,40 & 0,40 & 0,36 & 0,19 & 0,24 & 0,32 \\
\hline 6.évfolyam & 0,24 & 0,24 & 0,39 & 0,40 & 0,38 & 0,40 & 0,37 & 0,17 & 0,36 \\
\hline
\end{tabular}

Megjegyzés: Minden összefüggés szignifikáns $\mathrm{p}<0,01$ szinten

A tantárgyi attitüdök és a vizuális kommunikáció teszten elért eredmények korrelációi lényegesen alacsonyabbak. -0,1 és 0,26 között ingadoznak. Mindhárom évfolyamon mindössze két korreláció szignifikáns, az egyik a matematika, a másik a magyar tantárgy iránti attitüd irányában (57. táblázat). A rajz és vizuális kultúra tantárgy kedvelésével nagyon csekély összefüggést mutatnak a korrelációs együtthatók. A 6. évfolyamban határozzák meg leginkább a tantárgyi attitüdök a vizuális kommunikáció teszten elért teljesítményt. Megállapíthatjuk, hogy nincs vagy csak gyenge összefüggés van a vizuális kommunikáció teszten elért eredménye és a tantárgyi attitüdök között. 

táblázata

\begin{tabular}{|c|c|c|c|c|c|c|c|c|c|}
\hline Változó & 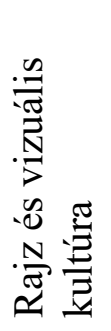 & 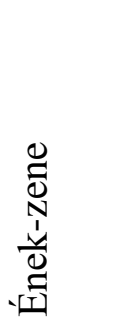 & 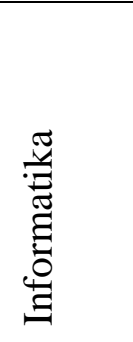 & 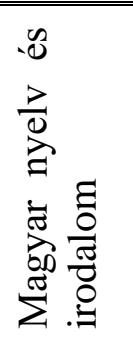 & 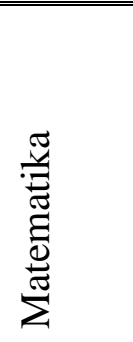 & 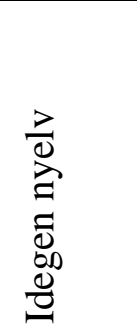 & 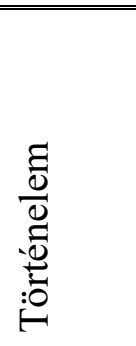 & 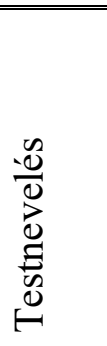 & 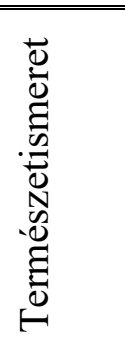 \\
\hline 4.évfolyam & 0,02 & $-0,02$ & 0,10 & $0,16^{* *}$ & $0,14 * *$ & 0,10 & - & 0,05 & 0,50 \\
\hline 5.évfolyam & 0,06 & $-0,10$ & $0,13^{*}$ & $0,15^{* *}$ & $0,1 * *$ & $0,26 * *$ & $0,16^{* *}$ & 0,09 & 0,07 \\
\hline 6.évfolyam & $0,12 *$ & 0,02 & $0,16^{* *}$ & $0,13 * *$ & $0,12 * *$ & $0,25 * *$ & $0,16^{* *}$ & 0,04 & $0,18 * *$ \\
\hline
\end{tabular}

Megjegyzés: ${ }^{*}=\mathrm{p}<0,05 ; * *=\mathrm{p}<0,01$

\subsection{A teszten elért eredmények a tanuláshoz való viszony szerint}

Az iskolai élet, az iskolában meghatározott szerepek valamint a tanuláshoz való viszony is meghatározóak lehetnek a teljesítményekben, ezért megkérdeztük a tanulókat a következőkröl:

- Mennyire szeretsz iskolába járni?

- Mi az a legmagasabb iskolai végzettség, amelyet szeretnél elérni?

- Mennyire vagy elégedett iskolai teljesítményeddel?

- Milyen a helyzeted az osztályodban?

Mindegyik kérdésre adott válasszal gyenge összefüggést mutatnak a korrelációs együtthatók (58. táblázat). A legerőteljesebb kapcsolat az elérendő iskolai végzettséggel áll fenn $(\mathrm{r}=0,21)$. Alacsony kapcsolat van a teszten elért teljesítmény és a „Magányosnak érzem magam.” állítás között $(\mathrm{r}=-0,16)$. Összességében elmondható, hogy bár szignifikáns, de gyenge kapcsolat van a teszten elért teljesítmény és az iskolához és a tanuláshoz kapcsolódó attitüdök és az tanulók osztályban elfoglalt helyzete között. A pozitív énkép, atudatos célmeghatározás és a teljesítmény között kismértékü pozitív kapcsolat van.

58. táblázat A vizuális kommunikáció teszten elért eredmények és a tanulást befolyásoló tényezök közötti korrelációk táblázata

\begin{tabular}{|c|c|c|c|c|c|c|}
\hline & 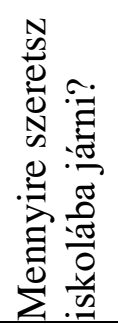 & 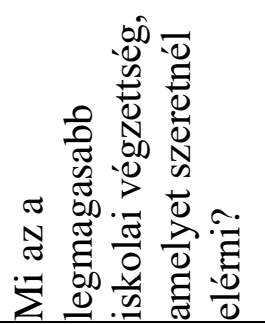 & 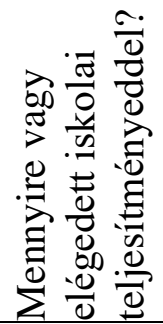 & 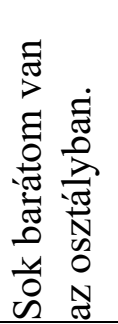 & 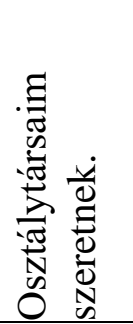 & 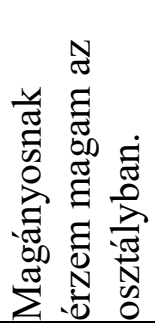 \\
\hline $\begin{array}{l}\text { Teljesítmény } \\
(\%)\end{array}$ & 0,17 & 0,21 & 0,2 & 0,12 & 0,08 & $-0,16$ \\
\hline
\end{tabular}

Megjegyzés: Mindegyik összefüggés szignifikáns p<0,01 szinten

\subsection{A családi háttér szerinti különbségek}

\subsubsection{A szülők legmagasabb iskolai végzettségének kapcsolata a teszten elért eredménnyel}

A szülök iskolai végzettségéről számos tanuló esetében hiányzó értékeket találunk. Az 1256 kitöltő közül 381 tanuló nem tudja, 103 pedig nem adott információt az anya iskolai végzettségéről. Az apa végzettségéről 390 fó választotta a „Nem tudom” választ és 127 tanuló nem töltötte ki a kérdőívnek ezt a részét. Az anya és az apa iskolai végzettsége és a teljes 
vizuális kommunikáció teszten elért teljesítmények korrelációját a 59. táblázatban foglaljuk össze. Mindkét összefüggés pozitív és szignifikáns $(\mathrm{p}<0,01)$, tehát a magasabb iskolai végzettségü szülők gyermekei jobb eredményeket érnek el.

59. táblázat A vizuáliskommunikáció teszten elért eredmény és a szülők iskolai végzettségének korrelációs táblázata

Teljes vizuális

kommunikáció teszt

Anya iskolai végzettsége

Apa iskolai végzettsége

$\mathrm{Az}$ árnyaltabb információk érdekében megvizsgáltuk a szülők végzettsége alapján elkülönülő csoportok teljesítményét (60. táblázat). A táblázat értékeit megfigyelve láthatjuk, hogy a szülők magasabb iskolai végzettségéhez magasabb szintű vizuális kommunikációs képesség társulnak. Az anya és az apa iskolai végzettsége egyaránt megmutatkozik az eredméynekben $(\mathrm{F}=14,74 \mathrm{p}<0,01 ; \mathrm{F}=15,67 \mathrm{p}<0,01)$. Az eredményeket az anya iskolai végzettsége szerint grafikusan is megjelenítettük (38. ábra).

60. táblázat A vizuális kommunikáció teszt eredményei szülök iskolázottsága szerinti bontásban

\begin{tabular}{lcccc}
\hline \hline Szülö iskolai végzettsége & $\begin{array}{c}\text { Anya } \\
\text { Antlag (\%) }\end{array}$ & $\begin{array}{c}\text { Apárás (\%) } \\
\text { Átlag (\%) }\end{array}$ & Szórás (\%) \\
\hline \hline nem fejezte be az általános & 53,16 & 15,04 & 52,06 & 19,90 \\
iskolát & & & & \\
általános iskola & 61,67 & 13,96 & 59,82 & 15,42 \\
szakiskola & 63,18 & 14,72 & 61,05 & 13,75 \\
szakmunkásképző & 67,29 & 13,18 & 70,01 & 11,58 \\
érettségi & 71,35 & 12,74 & 69,86 & 12,63 \\
föiskola (felsőfokú & 72,95 & 11,94 & 72,21 & 13,65 \\
alapképzés) & & & & 12,43 \\
egyetem (felsőfokú & 71,2 & 12,68 & 71,34 & \\
mesterképzés) & & & & \\
\hline
\end{tabular}

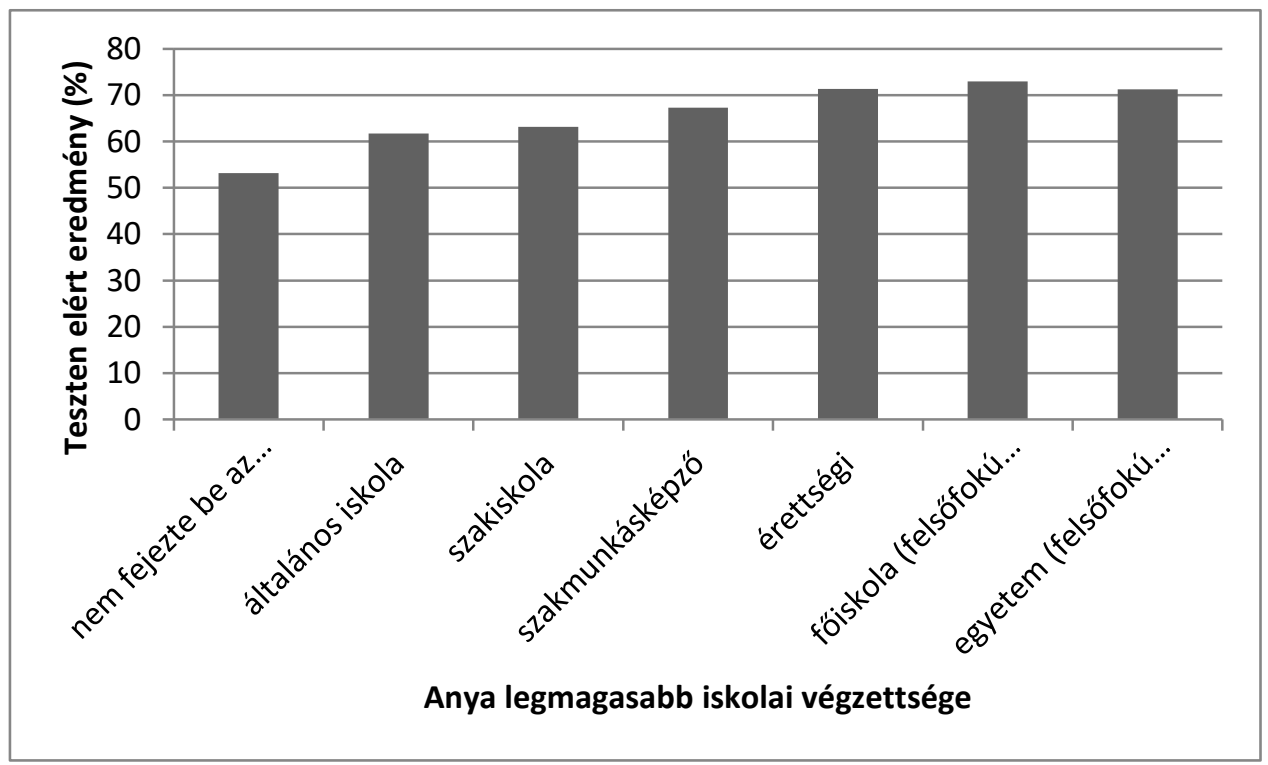

38. ábra A vizuális kommunikáció teszten elért százalékos eredmény az anya legmagasabb iskolai végzettsége szerinti bontásban 
A varianciaanalízis Tukey’s-b post hoc elemzése alapján az átlagok között az érettségifőiskola-egyetem között nincs szignifikáns különbség. Különösen az általános iskolát be nem fejező szülők gyermekei vannak lemaradásban.

\subsubsection{A teszten elért eredmény kapcsolata egyéb szociális háttérváltozókkal}

A családi háttér részletesebb vizsgálatához bevontunk az elemzésbe néhány egyéb információt adó állítást és kérdést is. A teszteredmények és a könyvek számával kimutatható kapsolat nagyon alacsony, de szignifikáns $(\mathrm{r}=0,25)$. A „Milyen gyakran történnek meg a következő dolgok a te családodban?” kérdéshez kapcsolódó állítások közül egyikkel sem mutatnak jelentős összefüggést a teljesítmények. Gyenge a kapcsolat teszteredmények és a család internetezési, valamint kiállításra, múzeumba járási szokásaival (61. táblázat). Az adatok alapján a felsorolásban szereplő közös családi tevékenységek és a vizuális kommunikációs képesség fejlettsége között nincs jelentős kapcsolat.

61. táblázat A vizuális kommunikáció teszten elért eredmény és a család szokásai közötti kapcsolat

\begin{tabular}{lcccccc}
\hline \hline & $\begin{array}{c}\text { Televízió } \\
\text { nézés }\end{array}$ & $\begin{array}{c}\text { Internetezés, } \\
\text { számítógépes } \\
\text { játék }\end{array}$ & Kirándulás & $\begin{array}{c}\text { Éneklés, } \\
\text { zenélés }\end{array}$ & $\begin{array}{c}\text { Kiállításra, } \\
\text { múzeumba } \\
\text { járás }\end{array}$ & $\begin{array}{c}\text { Moziba, } \\
\text { színházba, } \\
\text { koncertre } \\
\text { járás }\end{array}$ \\
\hline \hline $\begin{array}{l}\text { Teszten } \\
\text { elért } \\
\text { eredmény }\end{array}$ & 0,00 & $-0,15^{* *}$ & $-0,02$ & $-0,03$ & $-0,09 * *$ & 0,02 \\
$(\%)$ & & & & & & \\
\hline
\end{tabular}

Megjegyzés: $*=\mathrm{p}<0,05 ; * *=\mathrm{p}<0,01$

\subsection{A számítógép-használat és a teszten elért eredmények kapcsolata}

Megvizsgáltuk a teszten elért teljesítmény és a tanulók előzetes számítógépes és internetezési tapasztalatai közötti összefüggéseket. Erre egyrészt azért volt szükség, hogy lássuk, az online platformon végzett mérés során egyenlő esélyekkel indulnak-e a tanulók, másrészt nincsenek még arra vonatkozóan információink, hogy az erőteljesen vizuális kommunikációra épülő digitális világhoz szokott gyerekeknek kifinomultabb-e a vizuális kommunikációs képességük. A tantárgyi osztályzatok közül az informatikával gyenge kapcsolatot találtunk (9.3. fejezet), ez alapján nem feltételezhetünk kapcsolatot a teszt eredményei és a számítógép használati, valamint internetezési szokások között. A számítógép használattal kapcsolatos előzetes tapasztalatok nem járnak együtt a teszten elért eredménnyel $(\mathrm{r}=-0,06)$, a gyerekek többségének a teljesítményét nem befolyásolta tehát a beviteli eszközök használatának előzetes ismerete vagy nem ismerete, nincsenek hatással a teszten elért teljesítményre. A technológiai alapú mérések lebonyolításához tehát nem szükséges eszközhasználati jártasság. Ez az eredmény megerösíti, hogy tanórai keretekben való alkalmazásuk helyénvaló, még az alacsony informatikai írástudású osztályokban is.

Megkérdeztük a tanulókat az internethasználat lehetőségeikről (4. melléklet). Szignifikáns és pozitív kapcsolatot észleltünk a teszten elért teljesítmény és az internethasználat lehetöségeik között. Bár a korrelációs együttható $(\mathrm{r}=0,1)$ értéke nem magas, mégis indokoltnak láttuk megvizsgálni, hogy a különböző válaszok elkülönítik-e a mintát részmintákra. Azt tapasztaltuk, hogy megoszlik a minta az átlagokat tekintve (Leveneteszt $=0,59 \mathrm{p}=0,56 ; \mathrm{F}=8,30 \mathrm{p}<0,01)$. A varianciaanalízis Tukey's-b post hoc elemzése alapján egyértelmüen elkülönül azoknak a teljesítménye, akiknek egyáltalán nincs lehetösége internetet használni.

Azok a tanulók, akiknek lehetősége van használni az internetet, de nem használják, illetve az internetfelhasználók nem mutatnak szignifikáns különbséget a teszteken elért teljesítményben. Ebböl arra következtethetünk, hogy nem maga az internethasználat 
támogatja a teszten nyújtott teljesítmény, hanem ez összefügg egyéb szociális háttérváltozókkal. 


\section{Összegzés}

A 21. században a digitális technológia térhódításával párhuzamosan a pedagógiai gyakorlatban is egyre inkább a technológia-alapú értékelési lehetőségek kerülnek előtérbe. Az online mérések elterjedtek nemzetközi és hazai színtereken egyaránt, egyre több területet érintenek, mint például a matematika, a természettudományok, az olvasás-szövegértés. A digitális képi kultúra terjedésével az információk áramlásában a vizualitás szerepe döntő fontosságúvá vált. Az Új Képkorszak alkotásainak jelentős mértékben digitális eszközökkel készül, illetve így osztják meg. Az egyre több és változatosabb képkészítő eszköz megjelenésével a vizuális kommunikáció, mint közlési forma jelentősége megnőtt, és a vizuális képességek fejlesztése és a fejlődés folyamatos nyomon követése fontosabbá vált. Kutatásunk elsődleges célja olyan technológia alapú mérőeszköz kidolgozása volt, ami megbízhatóan méri a vizuális kommunikációs képesség fejlödését az iskola 4-6. évfolyamában.

Az értekezés első fejezeteiben összegeztük a vizuális kommunikációval kapcsolatos elméleteket, és tantervelemzéssel és meghatároztuk a területen zajló fejlesztés tartalmát. , Meghatároztuk a vizuális kommunikációhoz köthető tevékenységeket és ezek fejlődési jellemzőit, , melyekre alapozhattuk a kutatásainkat. A vizuális kommunikáció a látás útján történő információközlés és -értelmezés, melynek része az önértelmezés, kapcsolatteremtés másokkal és a világgal, valamint a látás útján történő probléma felismerés és megoldás a vizuális kultúra tárgy és jelenségvilágának direkt és indirekt úton történő használatával.

A vizuális képességrendszeren belül, korábbi kutatások eredményeit felhasználva (6.1. fejezet) értelmeztük a vizuális kommunikációs képességet, azon belül is a technológia által meghatározott befogadói képességekre fókuszáltunk. Így négy részképességet (absztrakció, komponálás síkban, szimbolizáció, modalitás váltás) azonosítottunk, mint a vizuális kommunikációs képesség részképességei, melyekhez három szintet (vizuális felismerés, vizuális értelmezés, vizuális elemzés) társítottunk. Ebben a rendszerben készítettük el a három évfolyam számára a vizuális kommunikációs képességet mérő teszteket.

A vizuális kommunikáció hazai és nemzetközi szakirodalmának áttekintése során nem találtunk olyan mérőeszközt, mely a napi iskolai gyakorlatban online alkalmazható lenne, ezért új feladatokat fejlesztettünk, illetve korábbi papíralapú, alkotó képességekre fókuszáló kutatások feladatai közül adaptáltunk és alkalmassá tettük online felületen való alkalmazásra. A feladatok megfelelnek a korosztály képi világának, játékosak, és könnyen értelmezhetök.

A teszteket a tanulók online közegben, a mindennapi tantárgyi keretek között töltötték ki, egy tanóra alatt. Az online felület könnyen kezelhető és azonnali visszajelzést biztosított a tanulóknak. A tanulók a hangszórók segítségével többször meghallgathatták a feladatok utasításait, ezzel megkönnyítve az olvasási nehézségekkel küzdők feladatát. A tanulók saját tempójukban haladhattak végig a teszteken, visszaléphettek, módosíthatták válaszaikat. A rendszer nem csak a tesztek kitöltését támogatta, hanem az adatok rögzítését is megkönnyítette. A teszteken nyújtott teljesítmények mellett az elemzéseket segítő háttér információkat is az online tesztkörnyezetben rögzítettük, így az adatok feldolgozása is egyszerüsödött.

A tesztekkel megvalósítható a vizuális kommunikációs képesség online mérése tanórai keretek között, iskolai környezetben. A tesztek kitöltése nem vett igénybe több időt, mint egy tanóra, megbízhatósági mutatóik megfelelőnek bizonyultak. Tesztünk feladatai beépíthetők a rajztanításba, segítik az egyes részképességek fejlődési problémáinak felismerését, illetve az alkotói feladatokban kevésbé jól teljesítő, de kiemelkedő befogadó képességekkel rendelkező tanulók azonosítását. Az első és a második hipotézis igazoltnak tekinthető.

Az IRT elemzés személy-item térképe megmutatta, hogy maradtak a tesztben kevésbé jól működő itemek, melyek a teljesítmények között nem megfelelően differenciálnak. A 
reliabilitás mutatók, az IRT elemzés alapján elmondható, hogy a mérőeszközök kisebb változtatásokkal alkalmasak a vizuális kommunikációs képesség mérésére.

A tesztekben a hipotetikus modell segítségével képzett részkonstruktumok közötti összefüggés pozitív és szignifikáns. Ugyanakkor a konfirmatív faktorelemzés során kapott illeszkedési mutatók közepes és gyenge illeszkedést mutatnak. A mért vizuális kommunikációs képességstruktúra tehát részben konzisztens a szakirodalom alapján felállított elméleti modellel (7.2. fejezet). A legjobb illeszkedést az 5. évfolyamos teszt mutat. A vizsgált konstruktum rendezettsége és szerkezete a vártnál kevésbé stabil minden évfolyamon, ezért a harmadik hipotézist nem igazoltuk.

A kutatás során megvizsgáltuk a vizuális kommunikációs képesség teszten elért teljesítmény és több háttérváltozó kapcsolatát. Az elemzések megmutatták, hogy az egyes évfolyamok között ugyan nincs szignifikáns különbség, de a korosztályokra bontott elemzés során már határozott különbségek fedezhetők fel. A vizsgált három évfolyam hat korcsoportot jelent. Különösen elkülönül az ún. túlkoros tanulók teljesítménye, akik a teszteken rosszabbul teljesítettek. Az elemzések alapján feltételezhető, hogy a kognitív éréssel nem jár együtt automatikusan a vizuális kommunikációs képesség fejlődése. Ezt támasztja alá az is, hogy egyes feladatok esetében (8.3. fejezet) a fiatalabb korosztály teszten elért eredménye jobb. Összegezve elmondható, hogy nem mutatható ki egyértelmű fejlődési tendencia a vizsgált korosztályokban, tehát a negyedik hipotézist megerősítettük. Az okainak feltárásáról érdemes erre irányuló vizsgálatokat végezni. Az elemzések megerősítették azt a feltételezést, hogy a nemek között nincs szignifikáns különbség a vizuális kommunikációs teszten elért teljesítményben, szemben a téri képességgel. A hatodik hipotézis tehát igaznak bizonyult.

A teszten elért teljesítmény és az osztályzatok közötti összefüggés közepes erősségü és szignifikáns, mely eredmény megerősíti a hetedik hipotézisünket. A legszorosabb kapcsolatot a matematika és a magyar nyelv és irodalom osztályzatokkal találtuk. Bár a kognitív éréssel eredményeink alapján nem fejlődnek automatikusan a vizuális kommunikáció részképességei, mégis van kimutatható kapcsolat a kognitív területekkel, ami felhívja a figyelmet a transzferhatásokra. A tényleges transzferhatások bizonyításához mélyebb elemzések szükségesek, de az eredmények arra utalnak, hogy a vizuális kommunikációs képesség fejlesztése jótékony hatással lehet számos kognitív területre. A rajz és vizuális kultúra tantárgy osztályzataival gyenge az összefüggés, ami tantervelemzésünkkel összevetve arra utal, hogy a vizuális kommunikációs befogadó képességek fejlesztési céljai a rajz és vizuális kultúra tantárgyban nem valósulnak meg.

Az ötödik hipotézisre vonatkozó, szociális háttérváltozók közül a szülök legmagasabb iskolai végzettsége pozitív és szignifikáns összefüggést mutat a teszten elért teljesítménnyel. A könyvek számára vonatkozó szociális háttérváltozó és a vizuális kommunikációs teszten elért eredmény között, bár gyenge, de szignifikáns kapcsolat van,

Igazolást nyert (nyolcadik hipotézis), hogy az előzetes számítógépes tapasztalatok nincsenek hatással a vizuális kommunikációs teszten elért teljesítményre, tehát a technológia alapú mérések lebonyolításához nem szükséges eszközhasználati jártasság. Ez kiegészíti első hipotézisünket, mely szerint a vizuális kommunikációs tesztek online mérése megvalósítható tanórai keretek között, alacsony informatikai írástudású csoportok esetén is.

Tesztünk további fejlesztést igényel, de mint a területen egyetlen ilyen eszköz, amely alapvetően fontos vizuális képességet vizsgál, nagyban segíti a vizuális kommunikációs képesség hatékonyabb oktatását. Az értekezésben bemutatott kutatási eredmények a vizuális kommunikációs képesség leírásának és az összefüggések vizsgálatának szűk területére korlátozódnak, nem fedik le a teljes spektrumot, de a szakirodalomban legfontosabbnak ítélt részképességeket sikerült megjelenítenünk. A mérőeszköz továbbfejlesztése során szeretnénk a méréseket kiterjeszteni kisiskolás és óvodáskorra is, hogy a képesség kialakulásáról és a fejlődés első szakaszáról is adatokat nyerjünk. A mérőeszköz továbbfejlesztésének ki kell 
terjednie a képességstruktúrát lefedő, stabil belső szerkezetű tesztek kialakítására, melyben a részkonstruktumok egyértelmüen elkülönülnek és illeszkednek a hipotetikus modellhez. Ezt elsősorban kevésbé összetett feladatok fejlesztésével, több item alkalmazásával érhetjük el.

Ugyancsak indokolt adaptív mérőeszköz kidolgozása is, egyrészt, hogy a tanulók a képességeikhez leginkább illeszkedő feladatokkal dolgozzanak, másrészt, hogy ez által is pontosabb képet kapjunk a fejlődési tendenciákról. A tesztek tartalma is módosítható, szükíthető a vizuális kommunikáció egyes tartalmaira, illetve bővíthető mozgóképpel, interaktív lehetőségekkel, melyek új szempontokat is beemelnek a kutatásba.

A mérési azonosítók alkalmazásával lehetőség nyílik a különböző területen folytatott mérések összevetésére, ezzel is komplexebb képet rajzolva a képességek fejlődéséről és összefüggésrendszeréről.

A diagnosztikus értékelés mellett az online felület lehetőséget biztosít újabb feladattípusok megjelenítésére is. Jövőbeli célunk olyan feladatbank kialakítása, mely az előzetes teszteredmények alapján egyéni, differenciálásra alkalmas játékos, interaktív, fejlesztő és gyakorló feladatokat tartalmaz, és lehetőséget biztosítanak a diákoknak és a pedagógusoknak egyaránt az adaptív, fejlesztve étékelő alkalmazásra. 


\section{Köszönetnyilvánítás}

Köszönettel tartozom a témavezetőmnek, Kárpáti Andreának, az ELTE TTK, Természettudományi Kommunikáció és UNESCO Multimédiapedagógia Központ vezetőjének, hogy inspirált és lehetőséget teremtett arra, hogy ötleteimet kipróbálhassam és megvalósíthassam. Köszönöm, hogy a legnehezebb utolsó lépések megtételéig támogatott és bíztatott. Köszönöm Pintér Henriett munkáját, aki a házi védés egyik opponenseként nagyban hozzájárult ahhoz, hogy az értekezés tartalmilag és formailag is kiérlelt legyen. Köszönöm a házi védés másik opponensének, Tóth Editnek a minden részletre kiterjedő szakmai véleményét, javaslatait, észrevételeit, amelyek további lényeges támpontokat adtak a dolgozat végső formába öntéséhez. Köszönöm Mokri Dórának, hogy mindig türelmes és segítőkész volt, mikor eltévedtem a statisztika útvesztöiben. Köszönöm a házi védésemen megjelentek bíztató jelenlétét, Molnár Gyöngyvér támogató szavait. Köszönettel tartozom azoknak az iskoláknak, vezetöiknek, tanáraiknak és tanulóiknak, akik a vizsgálattal kapcsolatos adatgyüjtésben, mérésben, értékelésben pótolhatatlan segítséget nyújtottak. Hálás vagyok a Szegedi Tudományegyetem Doktori Iskolájának és vezetőjének Csapó Benőnek, hogy színvonalas, inspiratív kutatási környezetben folytathattam doktori tanulmányaimat és végezhettem kutatásomat. Köszönöm a doktori iskola valamennyi oktatójának és hallgatójának, hogy egy produktív, dinamikus közösséghez tartozhatok, és hálás vagyok nem utolsó sorban az éves csapatépítő vitorlázásokért. Külön köszönettel tartozom Pásztor Attilának, akihez bármikor fordulhattam kérdéseimmel, és konstruktívan segített a kutatás során felmerült problémák megoldásában. 


\section{Irodalom}

Achen, Sven Tito (1981): Symbols Around Us, Van Nostran Reinhol Company, London

Antik Sándor (2010): Vizuális megismerés és kommunikáció. Egyetemes Mühely Kiadó és Bolyai Társaság, Kolozsvár.

Apscott, Don (2001): Digitális gyerekkor. Az internetgeneráció felemelkedése. Kossuth, Budapest.

Arnheim, Rudolf (1954/2004): Az alkotó látás pszichológiája. Aldus Kiadó, Budapest.

Arnheim, Rudolf (1969): Visual Thinking. Berkeley, University of California Press, Berkeley.

Arnheim, Rudolf (1974): A kifejezés (expresszió) alaklélektani elmélete. In Kardos Lajos (szerk.): Alaklélektan. Gondolat Kiadó, Budapest.

Arnheim, Rudolf (1974/1979): A vizuális élmény - Az alkotó látás pszichológiája. Gondolat Kiadó, Budapest

Asztalos Kata (2016): A zenei észlelési képesség szerkezete és fejlödése 5-17 éves korban. Doktori értekezés. SZTE, NDTI, Szeged.

Babály, B., Kárpáti, A. (2016). The impact of creative construction tasks on visuospatial information processing and problem solving. Acta Politechnica Hungarica, 13(7), 159$180 \mathrm{http}: / /$ uni-obuda.hu/journal/Babaly_Karpati 71.pdf

Babály, Bernadett., Budai, László, Kárpáti Andrea (2013): A térszemlélet fejlődésének vizsgálata statikus és mozgó ábrás tesztekkel. Iskolakultúra, 2013(11), 6-19.

Bábosik István (1997): A modern nevelés elmélete. Telosz, Budapest.

Bacon, Francis 1605/1893. The Advancement of Learning. szerk. David Price. London, cassell and co., London. www.gutenberg.org/ebooks $/ 5500$

Baddeley, Alan 2001. Az emberi emlékezet. Budapest, Osiris Kiadó. 645 p.,

Bakos Tamás, Bálványos Huba, Preisinger Zsuzsa, Sándor Zsuzsa (2000): A vizuális nevelés pedagógiája. Balassi Kiadó, Budapest

Balázsi Ildikó, Ostorics László, Szalay Balázs (2007): PISA 2006. Összefoglaló jelentés. Oktatási Hivatal, Budapest

Balázsi Ildikó, Szabó Vilmos, Szalay Balázs (2005): A matematikaoktatás minősége, hatékonysága és az esélyegyenlőség. A PISA 2003 nemzetközi tudásmérés magyar eredményei. Új Pedagógiai Szemle, 11. sz.

Balázsi, I., Balkányi, P., Ostorics, L., Palincsár, I., Rábainé Szabó, A., Szepesi, I., Szipőcsné Krolopp, J.,, Vadász, Cs. (2014): Az Országos kompetenciamérés tartalmi keretei. Oktatási Hivatal. Budapest

Bálványos Huba, Sántha László (2003 \{1998\}): Vizuális megismerés, kommunikáció. Balassi Kiadó, Budapest

Bamford, A (2006): The Wow Factor: Global Research Compendium ont he Impact of the Art sin Education, Münster, New York, Berlin: Waxmann

Barabási Albert-László (2008): Behálózva. A hálózatok új tudománya. Helikon Kiadó, Budapest.

Barabási Albert-László (2010): Villanások. A jövő kiszámitható. Nyitott Könyvmühely, Budapest.

Barnlund, Dean C. (1970/2003): A kommunikáció tranzakciós modellje. In Horányi Özséb (szerk.): Kommunikáció I. A kommunikatív jelenség. General Press Kiadó, 26-42. old.

Bartlett, Sir Frederic (1985): Az emlékezés. Kisérleti és szociálpszichológiai tanulmány. Budapest, Gondolat Kiadó, 430 p.

Bätschmann, Oscar (1998a): The Artist in the Modern World: The Conflict Between Market and Self-Expression. DuMont Buchverlag, Köln

Bätschmann, Oskar (1998b): Bevezetés a müvészettörténeti hermeneutikába. Corvina Könyvkiadó

Baudrillard, Jean (1987): A tárgyak rendszere. Gondolat Kiadó, Budapest 
Benkőné Zsemlye Erzsébet (1964): Adatok 4-8 éves gyermekek személyiségvizsgálatához rajzvizsgálatok alapján. A Goodenough-féle teszt hazai alkalmazhatósága. In: Pszichológiai Tanulmányok, VI. Akadémiai Kiadó, Budapest. 575-593.

Berényi, E. (2010). A mérési iskoláktól az iskolák megméréséig. Educatio, (4), 601-613.

Béres István és Horányi Özséb (szerk.)(2001): Társadalmi kommunikáció. Budapest, Osiris Kiadó. 22-34.

Berlyne, D.E. (1995) A kollativ változók. In: Farkas, A., Gyebnár, V. (szerk.) Vizuális müvészetek pszichológiája. Nemzeti Tankönyvkiadó, Budapest, 23-50.

Bickerton, D (1992): A reprezentációs rendszerek kezdetei. Café Bábel, 3-4, 83-95.

Billmayer, F. (2016): Situations in which visual literacy competencies are required and in which they become apparent. In: In: Wagner, E. és Schönau, D. Hrsg.: Gemeinsamer Europäischer Referenzrahmen für Visual Literacy / Common European Framework of Reference for Visual Literacy. A Prototyp. Münster-New York: Waxmann Verlag, 211245.91-98.

Blaskó Ágnes, Margitházi Beja szerk. (2010): Vizuális kommunikáció. Szöveggyüjtemény. Typotex Kiadó. Budapest.

Bodóczky István (2000): Az értékelés problémái a vizuális nevelésben. Iskolakultúra, (2000) 6-7, 15-25. http://real.mtak.hu/61321/1/EPA00011_iskolakultura_2000_06_07_015025.pdf

Bodóczky István (2002a): A rajz, vizuális kultúra tantárgy helyzete és fejlesztési feladatai. Új Pedagógiai Szemle, 52. 10. sz. 59-72.

Bodóczky István (2002b): A rajz, vizuális kultúra tantárgy helyzetének elemzése. Kézirat OKI.

Bodóczky István (2003): A vizuális nevelés megújítása, új paradigmája. Új Pedagógiai Szemle. 2003/07-08.

Bodóczky István (2009): Áthallások - Transzdiszciplináris vizuális nevelés. Iránypont. 2009/Különszám. MOME

Boehm, Gottfried, (szerk.) (1994): Was ist ein Bild? München, Wilhelm Fink Verlag. 13.

Boring, E.G. (1942) Sensation and perception in the history of experimental psychology. New York: Appleton-Century.

Bornstein Ruth (1984/1997): That's how it is when we draw: poems and pictures Clarion Books, New York.

Boughton, Douglas (2004): Assessing art learning in changing contexts. In: Eisner, E. Day, M. (szerk.): Handbook of research and policy in art education and evaluation. Laurence Erlbaum, New York. 585-606.

Boughton, Douglas és Ligtvoet, J. (1996): Evaluating and assessing the visual arts in education: International perspectives. Teachers College Press, Boston.

Bubik Veronika, Simon Tünde (2016): Vizuális kommunikáció: a 21. század domináns közlésmódja a kortárs müvészetben és tudományban, megjelenése a vizuális nevelésben. Neveléstudomány. 2016_2_29-42

Czúni László, Tanács Attila (2011: Képi információ mérése, Typotex Kiadó, Budapest.

Cseh Szilvia (2015): „Ki fog itt tudni?” A visual literacy elméletek és a kreativittás a konvergencia korában. Jelkép. 2015/4.

Boughton, Douglas G. (2013): Assessment of perfomance in the visual arts: what, how and why? In: Kárpáti, Andrea \& Gaul, Emil szerk.: From Child Art to Visual Language of Youth. - New Models and Tools for Assessment of Learning and Creation in Art Education. Intellect Publishers, Bristol, 119-142.

Bruner és mtsai (szerk)(1966): Studies in Cognitive Growth. John Wiley \& Sons, New York

Bubik Veronika (2013): Vizualizáció a tudománykommunikációban. Egyetemi jegyzet a Grafika és a tipográfia, a Kiadványszerkesztés - esztétikai, technikai alapismeretek, a 
Vizuális megismerés, és a Vizuális nyelv alapjai tantárgyakhoz http://elte.prompt.hu/sites/default/files/tananyagok/VizualizacioATudomanykommunika cioban/vizualizacio_a_tudomanykommunikacioban.pdf

Buda Béla (2000): A közvetlen emberi kommunikáció szabályszerüségei. Animula Kiadó, Budapest.

Cairo, A. (2012): The Functional Art. An Introduction to Information Graphics and Visualisation. New Riders, Berkeley.

Carey, James W.: Communication as Culture. Essay on Media and Society. Routledge: London-New York, 1992. p. 29.

Chen, M., Jackson, W.A., Parsons, C., Sindt, K.M., Summerville, J.B., Tharp, D.D., Ullrich, R.R., and Caffarella, E.P. (1996). The effects of font size in a hypertext computer based instruction environment. In Proceedings of Selected Research and Development Presentations at the 1996 National Convention of the Association for Educational Communications and Technology (18th, Indianapolis, IN).

Chrystal, David (2003): A nyelv enciklopédiája. Osiris Kiadó. Budapest

Clariana, R. és Wallace, P. (2005): Test mode familiarity and performance-gender and race comparisons of test scores among computer-literate students in Advanced Information Systems Courses. Journal of Information Systems Education, 16. 2. sz. 177-182.

Cole, M., Cole, S. R., Kéri, R., Csibra, G., Ragó, A. (2006): Fejlödéslélektan. Budapest: Osiris.

Csányi Vilmos (1994): Viselkedés, gondolkodás, társadalom: etológiai megközelités. Akadémiai Kiadó, Buda-pest.

Csányi Vilmos (2006): A kommunikációs kényszer. Magyar Tudomány, 2006/4 393. o.

Csányi Vilmos (2012): Kreatív kommunikáció. Magyar Szemle, Új folyam XV. 6. szám

Csapó Benő (szerk.)(2002a): Az iskolai tudás (Második kiadás). Osiris Kiadó, Budapest.

Csapó Benő (szerk.)(2002b): Az iskolai müveltség. Osiris Kiadó, Budapest

Csapó Benő és Varsányi Zoltán (1985): A rajzkészség fejlettségének vizsgálata középiskolai tanulóknál. Acta Univ. Szeg. de A. J. nom. Sectio Paed. et Psych. Ser. Spec. Paed., Szeged.

Csapó Benő, Molnár Gyöngyvér, Kinyó László [2009]: A magyar oktatási rendszer szelektivitása a nemzetközi összehasonlító vizsgálatok eredményeinek tükrében. Iskolakultúra, 3-4. sz. 3-13. o.

Csapó Benő, R. Tóth Krisztina, Molnár Gyöngyvér, Thibaud Latour, (2011) Az online tesztelés lehetőségei és a TAO platform alkalmazása. Új Pedagógiai Szemle. 61.évf. 15.

Csapó Benő (2002): A tudáskoncepció változása: nemzetközi tendenciák és a hazai helyzet. Új Pedagógiai Szemle 2002 február

Csapó, Benő, Molnár, Gyöngyvér, R. Tóth, Krisztina (2008). A papír alapú tesztektől a számítógépes adaptív tesztelésig: a pedagógiai mérés-értékelés technikájának fejlődési tendenciái. Iskolakultúra, (3-4), 3-16.

Császár Lilla (2016). ÉNKÉPezés, KÉPMÁSolás. Vizuális kommunikáció és énmegjelenítés a közösségi hálón. PhD értekezés. Pécsi Tudományegyetem, „Oktatás és társadalom” Doktori Iskola, PhD https://doktori.hu/index.php?menuid=192\&lang=HU\&sz_ID=23183

Crary Johnathan (1999): A megfigyelö módszerei. Osiris. Budapest.

Csépe, V., Győri, M., Ragó, A. (2008). Általános pszichológia 3. .Budapest: Osiris.

Csíkszentmihályi Mihály (1988): Society, Culture, and Person: A Systems View of Creativity. In: Stemberg, Robert (ed.): The Nature of Creativity: Contemporary Psychological Perspectives. Cambridge University Press, Cambridge, 325-339. 
Csőregh Éva (1991) Rajzoktatásunk története. Eidos füzetek 5. Magyar Rajztanárok Országos Egyesülete, Budapest

Damasio Antonio R. (1996):, Descartes tévedése: Érzelem, értelem és az emberi agy. AduPrint. Budapest

Debes, J. (1969). The Loom of Visual Literacy--An Overview. Audiovisual Instructions, 14(8), 25-27

Dorn, Charles M; Madeja, Stanley S; Sabol, F Robert (2003): Assessing Expressive Learning : a Practical Guide for Teacher-directed Authentic Assessment in K-12 Visual Arts Education. Lawrence Erlbaum Associates. Hoboken.

Drahos István (1988): Az elsőéves hallgatóság térszemléletére és ábrázolási készségére vonatkozó vizsgálatok. Eidos Füzetek 3. - Térszemlélet, térfogalom, térrendezés. Magyar Rajztanárok Országos Egyesülete, Budapest. 9-15.

Duchowski, Andrew T. (2007): Eye Tracking Methodology. Springer, London Eco, Umberto (1998): A tökéletes nyelv keresése. Atlantisz. Budapest.

Eco, Umberto (szerk.) (2010): A szépség története. Európa Kiadó Bickerton Derek; Lukács Ágnes: (2004): Nyelv és evolúció. Gondolat,. Budapest. Rhoda Kellogg (1977): Analyzing children's art. Palo Alto : Mayfield Pub. London

Elkins, James (2003): Mi a visual studies? Fordította Hornyik Sándor. Eredeti mü: James Elkins: Visual Studies. A Skeptical Introduction. Routledge, New York and London

Eplényi Anna (Szerk.) (2006): Kis GYIK könyv. Budapest, V-Print kiadó

Farkas András (2003). Az esztétikai ítélet - Müvészetpszichológiai modellek. Budapest: Universitas Kiadó.

Farkas, András, Gyebnár Viktória. (szerk.) (1995):Vizuális művészetek pszichológiája 1. Nemzeti Tankönyvkiadó, Budapest, 159-202.

Fercsik Erzsébet, Raátz Judit （2006): Kommunikáció ｅ́s nyelvhasználat. Nemzeti Tankönyvkiadó

Feuer Mária (2000): A gyermekrajzok fejlődéslélektana. Akadémiai Kiadó, Budapest.

Flusser, Vilém (1992): Képeink..2000, 1992/2.,

Flusser, Vilém (2005): Paradigmaváltás http://www.c3.hu/\%7Etillmann/forditasok/FLUSSER/para.html

Forgács Éva (2010): Bauhaus. Jelenkor, Pécs, 2010

Forgács Éva (1973): A Bauhaus és a művészet új fogalma. Valóság, 1973/6. 21-32.

Freedman, K., Hejnen, E., Kallio-Tavin, M., Kárpáti, A., Papp, L. (2013): Visual Culture Networks for Learning: How and What Students Come to Know in Informal Art Groups. Studies in Art Education, 54(2), 103-115.

Freedman, Kerry (2003): Teaching Visual Culture. Teachers College Press, New York

Freedman, Kerry (2010): Rethinking Creativity; A Definition to Support Contemporary Practice. Art Education. 63, 2, 8-15.

Frick, Ulrich (2018). Report on a national quantitative assessment study in visual literacy. Competences in art education: Structure, assessment and assignments in diverse educational contexts. Conference, Paris 1-Sorbonne, 2-13 March 2018.

Futó J. Attila (1995): A képi formanyelv dimenziói. In: Kárpáti Andrea (szerk.): Bevezetés a vizuális kommunikáció tanitásához. Nemzeti Tankönyvkiadó, Budapest. 93-110.

Gajdics Sándor (2003): A személyiség szocializációja és az értékelés összefüggései. Fejlesztő Pedagógia, 13. 2-3. sz. 41-47.

Gardner, Howard (1983): Artful scribbles. Harvard University Press, Boston.

Gardner, Howard (1996): The Assessment of Student Learning in the Arts, In: Boughton, Doug - Eisner, E. W. - Ligtvoet, J. (eds.) (1996): Evaluation and Assessment of Visual Arts Education: International Perspectives. Teachers College Press, NY, 131-155. 
Chafe Wallace, L (1980.): The pear stories: Cognitive, cultural, and linguistic aspects of narrative production. Norwood,

Gaul Emil (2001): A tervezö-konstruáló képességek szerkezete és fejlõdése 12-16 éves korban. PhD-értekezés. Kézirat. ELTE Neveléstudományi Doktori Iskola, Budapest.

Gaul Emil (szerk. 2015): A fiatalok digitális képi világa. Nyíregyháza: Bessenyei Kiadó.

Gaul Emil (szerk. 2016): Vizuális kommunikáció - Tanulmányok rajztanárok számára Nyíregyháza: Bessenyei Kiadó.

Gerbner, George (2002): A média rejtett üzenete. Válogatott tanulmányok. Osiris Kiadó MTA-ELTE Kommunikációelméleti Kutatócsoport, Budapest. 157 p.

Gerö Zsuzsa (1973/2007): Gyermekrajzok esztétikuma, Flaccus Kiadó, Budapest

Gerő Zsuzsa (1981): Informatív elemek változása a rajzfejlődés folyamán. Magyar Pszichológiai Szemle, XXXVIII. kötet, 22. 4. sz. 342-357.

Gerő Zsuzsa (1983a): A gyermekkori esztétikus rajzolás hatása a kreativitás további fejlődésére. Magyar Pszichológiai Szemle, XXXVI. kötet, 24. 3. sz. 244-255.

Gerő Zsuzsa (1983b): Esztétikusan rajzoló gyermekek kreativitásának követése serdülőkorig. In Kreativitás és deviáció. Pszichológiai Mühely sor. Akadémiai Kiadó, Budapest

Gibson E J.(1969): Principles of perceptual learning and development. AppletonCenturyCrofts. New York. 537 p.

Golomb, Claire (1974): Young children's sculpture and drawing a study in representational development. Harvard University Press, Cambridge.

Gombrich, Ernst H. (1959/1972): Müvészet és illúzió. A képi ábrázolás pszichológiája. Fordította Szabó Árpád. Budapest, Gondolat Kiadó. Eredeti mü: 1959, by the Trustees of the Nationally Galery of Art Washington D. C.

Gombrich, Ernst H.(1991/1999): Miröl szólnak a képek? Beszélgetések müvészetröl és tudományról. Balassi Kiadó, Budapest.

Goodenough, Florence L (1926): Measurement of intelligence by drawings, onkers-onHudson, N.Y., Chicago, World Book Company

Goodman, N. (1977) When is art? In: The arts and cognition (eds.: Perkins and Leondar), The Johns Hopkins University Press, pp. 11-19

Goodnow, Jacqueline J. (1977): Children's drawing. Fontana. London

Griffin, E. (2001 [1991]): Bevezetés a kommunikációelméletbe. Fordította: Szigeti L. László.

Groenendijk, T., Haanstra, F., Kárpáti, A. (submitted). Self-assessment in art education through a visual rubric. International Journal of Education through Art (IJETA), 14(3), 353-378.

Groenendijk, T., Haanstra, F., Kárpáti, A. (bírálat alatt). New tool for developmental assessment based on the Common European Framework of Reference for Visual Literacy - an international usability study. International Journal of Art and Design Education (IJADE).

Gross, C. (2004): Agy, látás, emlékezet. Typotex, Budapest.

Haanstra, F., Damen, M-L.ésHoorn, M. van (2011):The U-Shaped curve in the low countries: a replication study. Visual Arts Research, 37.72. sz.16-29.

Haanstra, Folkert, Schönau, Diederik (2007): Evaluation Research in Visual Arts Education. In: Bressler, Liora (ed.): International Handbook of Research in Arts Education. Springer Netherlands, Amsterdam, 427-444.

Engberg, Maria -Bolter, Jay David (2014) Cultural expression in augmented and mixed reality. Convergence: The International Journal of Research into New Media Technologies, 2014. Vol. 20 (3-9)

Haftmann, W. (1950/1988): Paul Klee. Corvina Kiadó, Budapest.

Halász László (1983): Müvészetpszichológia. Gondolat, Gondolat.

Halász László (2002): A freudi müvészetpszichológia - Freud, az író. Gondolat, Budapest. 
Halász László, Hantos Károly, Faa Balázs. (2002): Az interaktív müvészeti CD-ROM hatása. Balassi Kiadó - Magyar Képzőmüvészeti Egyetem, Budapest.

Hampshire, Stephenson (2009): Jelek és szimbólumok. Scolar Kiadó, Budapest.

Hárdi István (2002): Dinamikus rajzvizsgálat. Medicina, Budapest

Harnad, S. (2001): Creativity: Method or Magic? University of Southampton, Department of Electronics and Computer Science; Intelligence, Agents and Multimedia Group, Harnar E-Print Archives

Havelock, Eric Alfred (1963/1994): Preface to Platon. Cambridge (Mass.), The Belknap Press of Harvard University Press, London.

Hegedűs Miklós, Kalmár István, Szabics Ágnes (Szerk.) (1997): A nagy GYIK könyv Kézikönyv a vizuális neveléshez. Budapest, Aula Kiadó

Hekkert és Wieringen (1995) A komplexitás és a prototipikusság mint a kubista festmények értékelésének meghatározói. In: Farkas, András, Gyebnár, Viktória (szerk.) Vizuális művészetek pszichológiája 1. Nemzeti Tankönyvkiadó, Budapest, 143-158.

Helmich Dezső, Szántó Zsolt (2004): A kultúra fogalmáról. In: Metodológia, társadalom, gazdaság: In memoriam Bertalan László. Közgazdasági Szemle Alapítvány, Budapest

Holšánová Jana (2008): Discourse, Vision, and Cognition, John Benjamins. Amsterdam.

Horányi Özséb (2001): A kommunikációról. In Béres István-Horányi Özséb (szerk.): Társadalmi kommunikáció. Osiris Kiadó, Budapest, 22-34. old.

Horányi Özséb (2003a) (szerk.): Kommunikáció I. A kommunikativ jelenség. Kommunikáció II. A kommunikáció világa. Budapest, General Press Kiadó

Horányi Özséb (2006): Jel, jelentés, információ, Magvető / General Press, 1975 / 2006

Horányi Özséb (Szerk.) (2003b): A sokarcú kép. Budapest, Typotex

Horányi Özséb (szerk.)(2007): A kommunikáció, mint participáció. Budapest, AKTI Typotex, 2007

Horányi Özséb, Szépe György (szerk.) (1975/2004): A jel tudománya, Gondolat / General Press, Budapest

Illés Anikó (2000) Kontextuális tényezők szerepe vizuális müalkotások befogadásában. In: A MPT XIV. Országos Nagygyülése, Budapest.

Illés Anikó (2008): Hová néz a szakértő? Mit lát a laikus? XVI. Magyar Kognitív Tudományok Konferencia: Szubjektív tudás - objektív tudomány, Budapest, okt. 28-30.

Imdahl, Max (1993): Gondolatok a kép identitásáról. Athenaeum

Imdahl, Max (2002): Ikonika, In. Bacsó Béla (szerk.): Fenomén és mü, Kijárat Kiadó, Budapest.

Infante, Dominic A., Rancer, Andrew S., Womack, Deanna F. (1991): Building Communication Theory. Illinois, Waveland Press, Inc.

Ivins Jr., W. M. (1954/2001): A nyomtatott kép és a vizuális kommunikáció. Enciklopédia Kiadó, Budapest (Prints and Visual Communication. Cambridge, 1953, MA, Harvard University Press.

Jensen, Klaus Bruhn (1995/2003): A kommunikáció ismeretelméleti és lételméleti szempontból. In Horányi Özséb (szerk.): Kommunikáció I. A kommunikatív jelenség. Budapest, 2003, General Press Kiadó, 170-208. p.

Józsa Krisztián (2001): Az elsajátítási motiváció és a kognitív kompetencia fejlesztése. In. Csapó Benő és Vidákovich Tibor (szerk) (2001): Neveléstudomány az ezredfordulón $162-175$

Julesz Béla (2000): Dialógusok az észlelésröl. Typotex, Budapest.

Kárpáti Andrea (1981a). 5. és 8. osztályos tanulók képzőmüvészeti tudásanyaga és ízlése. Magyar Pedagógia, 4. sz. 376-391.

http://misc.bibl.uszeged.hu/13166/1/mp_1981_004_5581_376-391.pdf 
Kárpáti Andrea (1981b). Kísérlet a müelemző készség kialakítására és fejlesztésére 6-10 éves gyermekeknél. Magyar Pedagógia, 1. sz. 49-62.

Kárpáti Andrea (1985a). Képolvasás. Vizuális nevelés sorozat, 1. Tankönyvkiadó, Budapest.

Kárpáti Andrea (1991): Látni tanulunk. Akadémia Kiadó, Budapest

Kárpáti Andrea (1992a): Leonardo Program - a vizuális nevelés öt modellje. Akadémiai Kiadó, Budapest.

Kárpáti Andrea (1992b). Látni tanulunk. A müelemzés tanitása az általános iskolában.

Közoktatási kutatások sorozat. Akadémiai Kiadó, Budapest.

Kárpáti Andrea (1993). A vizuális kommunikáció, mint tantárgy. Iskolakultúra. 15-16. sz. $55-61$.

Kárpáti Andrea (1995a, szerk.): Bevezetés a vizuális kommunikáció tanításához. Nemzeti Tankönyvkiadó, Budapest.

Kárpáti Andrea (1995b): Projekt rendszerü vizsga a vizuális nevelésben. Új Pedagógiai Szemle, $1995 / 11$

Kárpáti Andrea (1995b, szerk.): Vizuális képességek fejlödése. Nemzeti Tankönyvkiadó, Budapest.

Kárpáti Andrea (1996). A Leonardo Program pedagógiai hatásvizsgálata. Magyar Pedagógia, 1. sz. 3-34.

Kárpáti Andrea (1997a): Az esztétikai tevékenység kitüntetett szerepe a reformpedagógiában In: Bábosik István (szerk.): A modern nevelés elmélete, IV/ 4. rész Budapest: Telosz Kiadó, 1997 86-115. old.

Kárpáti Andrea (1997b): Vélemények a vizuális kultúra alapműveltségi vizsga általános követelményeiröl. Uj Pedagógiai Szemle 47. 5.sz. 117-124.

Kárpáti Andrea (1997c): Vizuális nevelés: projekt módszerü vizsga. Calibra Kiadó, Budapest. Kárpáti Andrea (1998): A művészeti projekt, mint vizsgamódszer. In: Hegedűs Gábor (szerk.): Projektmódszer I. Kecskeméti Tanítóképző Főiskola, Kecskemét. 68-80.

Kárpáti Andrea (2001): Firkák, formák, figurák - a vizuális nyelv fejlődése a kisgyermekkortól a kamaszkorig. Dialóg Campus Kiadó, Budapest.

Kárpáti Andrea (2002): A vizuális müveltség. In: Csapó Benő (szerk.): Az iskolai müveltség. Osiris, Budapest. 91-134.

Kárpáti Andrea (2003): Mérni a mérhetetlent. Teljesítményértékelés a vizuális nevelésben. Iskolakultúra, 13. 8. sz. 95-106.

Kárpáti Andrea (2005): Kamaszok vizuális nyelve. Akadémiai Kiadó, Budapest

Kárpáti Andrea (2009): Kommunikáció, technika, kreativitás: egy komplex mérőeszköz a vizuális képességek értékelésére. Új Pedagógiai Szemle 2009/5-6

Kárpáti Andrea (2011). Esztétikai nevelés az Új Képkorszakban: a gyermekrajzoktól a vizuális nyelvig. Magyar Tudomány, 2011/9, 1058-1064.

http://www.matud.iif.hu/2011/09/05.htm

Kárpáti Andrea (2013): „Gyermekrajz” a 21. században: egy új fejlődéselmélet felé. In: Molnár, Gyöngyvér, Korom, Erzsébet (szerk.): Az iskolai sikerességet befolyásoló kognitív és affektív tényezök értékelése. Nemzedékek Tudása Tankönyvkiadó Zrt., Budapest. 105-122. old.

Kárpáti Andrea (2016). Kamaszok digitális kreativitása és a vizuális nevelés: kihívás és lehetőség. In: Kolosai Nedda, M. Pintér Tibor (szerk).: A gyermekkultúra jelen(töség)e. Budapest: ELTE Tanító és Óvóképző Kar, pp. 237-250. Kötet: http://gyermekkultura.tok.elte.hu/docs/Gyermekkultura_ebook.pdf

Kárpáti Andrea (2018): Művészet alapú oktatás, kutatás alapú müvészetpedagógia Magyar Tudomány, $\quad 6, \quad$ https://mersz.hu/mod/object.php?objazonosito=matud_f7939_i1 DOI: 10.1556/2065.179.2018.6.1 
Kárpáti Andrea, Gaul Emil (1998): A tervezőképesség értékelése projekt módszerrel 12-16 éves tanulók körében. In: Báthory Zoltán (szerk.): Közoktatás - kutatás 1996-1997. Müvelődési és Közoktatási Minisztérium, Budapest. 321-349.

Kárpáti Andrea, Gaul Emil (2011). A vizuális képességrendszer: tartalom, fejlődés, értékelés. In: Csapó, Benő, Zsolnai, Anikó (szerk.) (2011). Kognitív és affektív fejlődési folyamatok diagnosztikus értékelésének lehetöségei az iskola kezdö szakaszában. Budapest, Nemzeti Tankönyvkiadó. 41-82.

Kárpáti Andrea, Gyebnár Viktória (1996). A vizuális képességek pedagógiai és pszichológiai mérésének összefüggései a Leonardo Programban. Magyar Pszichológiai Szemle, 1996, LII. (36), 4-6., 273-296.

Kárpáti Andrea, Kovács Antalné (2009): Kommunikáció, technika, kreativitás: egy komplex mérőeszköz a vizuális képességek értékelésére. Új Pedagógiai Szemle, 59. 5-6. sz. 4059.

Kárpáti Andrea, Köves Szilvia (szerk.) (2001): Rajztanitás a XIX. századi Magyarországon. Magyar Iparmüvészeti Egyetem, Budapest

Kárpáti Andrea, Pataky Gabriella (2016): A Közös Európai Vizuális Műveltség Referenciakeret. Neveléstudomány.2016/05. 6-21.

Kárpáti Andrea, Pethő Villő (2012). A vizuális és zenei nevelés eredményeinek vizsgálata. In: Csapó Benö (szerk.): Mérlegen a magyar iskola. Nemzeti Tankönyvkiadó, Budapest, 451-483.

Kárpáti Andrea, Séra László, Gulyás János (2002): A térszemlélet. A vizuális-téri képességek pszichológiája, fejlesztése és mérése. Comenius Kiadó, Pécs.

Kárpáti Andrea: Esztétikai nevelés az új képkorszakban: a gyermekrajztól a vizuális nyelvig. Magyar Tudomány. 2011. szeptember. 1058-1065

Kárpáti, Andrea, Gaul, Emil (2010): A gyermekrajztól a vizuális kommunikációig - egy képességrendszer iskolai fejlődésének vizsgálata 6-12 éves korban. Új törekvések és lehetőségek a 21. századi neveléstudományokban. Zárókötet. X. Országos Neveléstudományi Konferencia. 2010. november 4-6. MTA Pedagógiai Bizottsága, Budapest. 100.

Kárpáti Andrea, Simon Tünde, Babály Bernadett (2015): Az eDIA online tesztrendszer pilot kísérletei a Térszemlélet és Vizuális kommunikáció területén. In: Zsolnai Anikó és Csapó Benő (szerk.): Online diagnosztikus mérések az iskola kezdö szakaszában.35-71.

Kárpáti, Andrea, Zempléni, A., Verhelst, N. V., Velduijzen, N. H., Schönau, D. W. (1998). Expert Agreement in Judging Art Projects - a Myth or Reality? Studies in Educational Evaluation, Vol. 24. No. 4. 385-404.

Kárpáti, Andrea, Gaul, Emil szerk (2013): From Child Art to Visual Language of Youth. New Models and Tools for Assessment of Learning and Creation in Art Education. Intellect Publishers, Bristol.

Kárpáti, Andrea, Freedman, K., Heijnen, E, Kallio-Tavin, M., Castro, J. C. (2016): Collaboration in Visual Culture Learning Communities: Towards a Synergy of Individual and Collective Creative Practice. International Journal of Art \& Design Education. DOI: 10.1111/jade.12099.

Kárpáti Andrea, Gyebnár Viktória (2013): The Test for Creative Thinking: an authentic tool for art education to assess creativity through visual expression. Visual Inquiry: Learning and Teaching Art, (2)1, 27-42.

Kárpáti, Andrea., Molnár, Gyöngyvér, Tóth, Péter, Főző, Attila (Eds.). (2008): A 21. század iskolája. Budapest: Nemzeti Tankönyvkiadó.

Kellog, Rhoda (1967): Child Art Collection. Washington, DC., Microcard Editions, Inc. Kepes György (1965): A világ új képe müvészetben és tudományban. Corvina, Budapest Kepes György (1979): A látás nyelve. Gondolat Kiadó, Budapest 
Kerschensteiner, Georg (1905): Die Entwicklung der zeichnerischen Begabung : neue Ergebnisse auf Grund neuer Untersuchungen. Carl Gerber. München.

Kince, Eli (1982): Visual puns in design, Watson-Guptil Publications, New York.

Kindler, Anna, Darras, Bernard (1997): Development of Pictorial Representation: A Teleology-based Model. Journal of Art \& Design Education, v16 n3 (199710): 217-222

Király Jenö (1992): A hétköznapiság esztétikája. Tankönyvkiadó Budapest

Kittler, Friedrich A. (2005): Optikai médiumok. Berlini elöadás, 1999. Magyar Mühely K.. Budapest

Kolta Magdolna (2003): Képmutogatók : a fotográfiai látás kultúrtörténete. Magyar Fotográfiai Múzeum, Kecskemét.

Kornis Gyula szerk. (1913): Ratio Educationis. I.-II. kötet Az 1777-iki Ratio Educationis. Pedagógiai Könyvtár. Katholikus Középiskolai Tanáregyesület, Budapest.

Kovács Gyula (2001): A vizuális tudat. Magyar Tudomány, 2001/10.

Környeiné Gere Zsuzsa (2001a): Látás és láttatás I. Módszertani Lapok, Vizuális Kultúra 5. évf./3 , 2001. szeptember,1-9.

Környeiné Gere Zsuzsa (2001b): Látás és láttatás II. Módszertani Lapok, Vizuális Kultúra 5. évf./4 , 2001. december,1-23.

Környeiné Gere Zsuzsa (2002): Látás és láttatás III. Módszertani Lapok, Vizuális Kultúra 6. évf./2, 2002. június, $1-7$.

Kunt Ernő (1989): Vizuális kultúra és vizuális müvészetek. Vizuális antropológiai jegyzetek 1. A Herman Ottó Múzeum évkönyve. 27. http://epa.oszk.hu/02000/02030/00023/pdf/HOM_Evkonyv_27_275-284.pdf

Kunt Ernő (2003): Az antropológia keresése. Válogatott tanulmányok. Szerk. Bán András. Budapest, MTA Néprajzi kutatóintézet és L'Hartmann Könyvkiadó

Laitinen, S. (2013): A national assessment of learning outcomes in art in the Finnish comprehensive school in 2010. In: Kárpáti, A., Gaul, Emil Eds. (2013). From Child Art to Visual Language of Youth. - New Models and Tools for Assessment of Learning and Creation in Art Education. Bristol: Intellect Publishers, 191-198.

Lakoff, George és Mark Johnson (1980): Metaphors We Live By, Chicago: University of Chicago Press

Lester, Paul Martin (2006): Visual Communication: Images with Messages. Belmont, CA: Thomson Wadsworth, 2006

Luquet Georges-Henri (1927):.La critique de la raison pratique chez les Yagan de la Terre de Feu. Paris : F. Alcan,

Löwenfeld, Margaret (1970):: The Lowenfeld World technique: studies in personality. Pergamon Press. Oxford.

Löwenfeld, Viktor, W Lambert Brittain (1947): Creative and mental growth. Macmillan etc. New York; Collier Macmillan. London.

Fodor, Jerry Alan (1983): Representations : philosophical essays on the foundations of cognitive science. The MIT Press. Cambridge.

Leoardo da Vinci (2005): A festészetről (Trattato della pittura). Szeged, Lectum Kiadó

McLuhan, Marshall (1962/2001): A Gutenberg galaxis. Trezor Könyv- és Lapkiadó, Terjesztő Bt. Budapest

Maczó Péter (2010): Az infodesignról. Scolar Kiadó, Budapest.

Magyar Andrea, Pásztor Attila, Pásztor-Kovács Anita, Pluhár Zsuzsa, Molnár Gyöngyvér (2015): A 21. században elvárt képességek számítógép alapú mérésének lehetőségei. In.: Tóth Zoltán (szerk.): Új Kutatások a Neveléstudományokban. Oktatás és nevelés gyakorlat és tudomány. MTA Pedagógiai Tudományos Bizottság, Debreceni Egyetem. 230-243.

Magyar, A. (2012). Számítógépes adaptív tesztelés. Iskolakultúra, 22(6), 52-60. 
Marr, D , Nishihara, H K (1978): Representation and recognition of the spatial organization of threedimensional shapes Proceedings of the Royal Society (Lond B), 200,269-94

Martin, R. (2009). Utilising the Potential of Computer-delivered Surveys in Assessing Scientific Literacy. In: Scheuermann, F. és Björnsson, J. (szerk.): The transition to computer-based assessment. New approaches to skills assessment and implications for large-scale testing. Office for Official Publications of the European Communities, Luxemburg. 172-166.

Martindale, C. (1995) Esztétika, pszichobiológia és megismerés. In: Farkas, András, Gyebnár, Viktória (szerk.) Vizuális müvészetek pszichológiája 1. Nemzeti Tankönyvkiadó, Budapest, 51-72.

Martindale, C., Moore, K., Anderson, K. (2005) The effect of extaneous stimulation on aesthetic preference. Empirical Studies of the Arts 23(2), 83-91

McCandless, D. (2010): Az információ gyönyörü. Typotex Kiadó, Budapest.

Mendelowitz, Daniel Marcus (1954): Children are artists: An introduction to children's art for teachers and parents, Stanford University Press, Stanford, Calif

Mérei Ferenc (1995a): Klinikai pszichodiagnosztikai módszerek. Medicina Könyvkiadó Rt.. Budapest

Mérei Ferenc (1995b) Az ízlésélmény elemzése. In: Farkas, András, Gyebnár, Viktória (szerk.) Vizuális müvészetek pszichológiája 1. Nemzeti Tankönyvkiadó, Budapest, 231248. old.

Messaris, Paul, Moriarty, Sandra (2005) Visual Literacy Theory. In: Smith, Moriarty, Barbatsis, Kenney (2005eds.) Handbook of Visual Communication: Theory, Methods, and Media. Mahwah, NJ: Lawrence Erlbaum and Associates.

Micheli, Mario De (1978): Az avantgardizmus. Képzőművészeti Alap Kiadóvállalata. Budapest

Miklós Pál (1980) Kép és kommunikáció. Budapest, MUOSZ Oktatási Igazgatósága

Miklós Pál (1995): Vázlat egy vizuális szemiotikához In: Kárpáti Andrea (szerk.): Bevezetés a vizuális kommunikáció tanításához. Nemzeti Tankönyvkiadó, Budapest, 60-73.

Milbrandt, M. K. (1998): Postmodernism in Art Education: Content for Life. Art Education, $51,(6), 47-53$.

Miorzeff, Nicholas (1999): Visual Culture. Routledge, New York

Mitchell W. J. T. (1994). The pictorial turn. In: Picture Theory. Essays on Verbal and Visual Representaion. Chicago: The University of Chicago Press, 11-35.

Molnár, Gyöngyvér (2005). Az objektív mérés megvalósításának lehetősége: a Rasch-modell. Iskolakultúra, (3), 71-80.

Molnár, Gyöngyvér (2007). Új ICT eszközök alkalmazása az iskolai gyakorlatban. In E. Korom (Ed.), Kihívások a XXI. század iskolájában (pp. 101-124). Szeged: Koch Sándor Tudományos Ismeretterjesztő Társulat.

Molnár, Gy. (2010). Technológia-alapú mérés-értékelés hazai és nemzetközi implementációi. Iskolakultúra, (7-8), 22-34.

Molnár, Gyöngyvér (2011). Az információs-kommunikációs technológiák hatása a tanulásra és oktatásra. Magyar Tudomány, 172(9), 1038-1047.

Molnár, Gyöngyvér (2013). A Rasch modell alkalmazási lehetöségei az empirikus kutatások gyakorlatában. Gondolat Kiadó. Budapest.

Molnár, Gyöngyvér (2015a). A képességmérés dilemmái: a diagnosztikus mérések (eDia) szerepe és helye a magyar közoktatásban. Géniusz Mühely Kiadványok, (2), 16-29.

Molnár, Gyöngyvér (2015b). Az óvoda és iskola feladatai az értelmi képességek fejlesztése terén. In M. Kónyáné Tóth, Cs. Molnár (Eds.), Tartalmi és szervezeti változások a köznevelésben (pp. 179-190). Debrecen: Suliszerviz Oktatási és Szakértői Iroda, Suliszerviz Pedagógiai Intézet. 
Morris Desmond (1997): Az emberállat: személyes vélemény az emberi fajról. Magyar Könyvklub. Budapest.

Naghshineh és mtsai,, Formal Art Observation Training Improves Medical Students' Visual Diagnostic Skills. US National Library of Medicine National Institutes of Health. 2008 Jul; 23(7): 991-997.

Nagy József (1998): A kognitív képességek rendszere és fejlődése. Iskolakultúra. 98/10. 3-22. Nagy József (2000): XXI. század és nevelés. Osiris Kiadó, Budapest.

Nagy László (1905): Fejezetek a gyermekrajzok lélektanából Singer és Wolfner Kiadó, 1905 Neisser, Ulric (1967/2014): Cognitive psychology. Hove : Psychology Press

Nemzeti Alaptanterv (2012): 110/2012. (VI. 4.) Korm. rendelet a Nemzeti alaptanterv kiadásáról, bevezetéséről és alkalmazásáról Oktatási Minisztérium, Budapest.

https://ofi.hu/sites/default/files/attachments/mk_nat_20121.pdf

Neurath, Otto (1980 [1936]): International Picture Language. Kegan paul, Trench, Trubner \& Co.Ltd., London

Moxey, Kieth, Norman Bryson, Michael Ann Holly, (1994): Visual Culture. Images and Interpretations. Wesleyan University Press, Hanover-London, 1994.

Nyéki Lajos (2005) Számítógéppel segített értékelés a felsőoktatásban In: Informatika a felsőoktatásban 2005 Konferencia, Debreceni Egyetem, 2005. augusztus 24-26.

Nyíri Kristóf (1995): Hálózat és tudásegész. In: Sándor Iván et al., (szerk.): A századvég szellemi körképe. Pécs, Jelenkor Kiadó. 117-135.

Nyíri Kristóf (2000a): A 21. század filozófiája felé. Előadás: Filozófia az ezredfordulón konferencia, Kecskemét, MTA Filozófiai Kutatóintézet, http:/www.philinst.hu/projects/kecske.met/nyiri_21.htm

Nyíri Kristóf (2000b): A gondolkodás képelmélete. Előadás az ELTE BTK Filozófiai Intézete és Nyelvfilozófiai Kutatócsoportja Nyelv, megértés, interpretáció - A nyelv, mint a kortárs filozófiai áramlatok közös problémája c. konferenciáján, 2000. 10. 5-6., HUNFI Oktatás- és Tananyagfejlesztő Szolgáltató Kft., http://www.hunfi.hu/nyiri/ELTE_2000_conf.htm

Nyíri Kristóf (2001b): Képjelentés és mobil kommunikáció. In: Nyíri Kristóf (szerk.): A 21. századi kommunikáció új útjai. MTA Filozófiai Kutatóintézete, Budapest. 59-79

Nyíri Kristóf (2002): Képek, mint eszközök Wittgenstein filozófiájában. Világosság, 41. 1. sz. 5-21.

Nyíri Kristóf (2007): Szavak és képek. Világosság 2007/9. http://www.vilagossag.hu/pdf/20071109200756.pdf

Nyíri Kristóf (2008): A tanulás filozófiája a mobil információs társadalomban In: Benedek András: Digitális pedagógia-tanulás IKT környezetben. Typotex Kiadó, Budapest

Nyíri Kristóf (2009): Virtuális pedagógia, a 21. század tanulási környezete. http://ofi.hu/tudastar/iskola-informatika/nyiri-kristof-virtualis

Nyíri (2012a): Vizuális hazatérés - a neveléstudomány képi fordulata In: Dr. Benedek András (szerk.): Digitális pedagógia - Tanulás IKT környezetben. Typotex. https://www.tankonyvtar.hu/hu/tartalom/tamop412A/2011-

0023_DP/dp5_2_vizhaza_ch000000.html

Nyíri Kristóf (2012b): A gondolkodás képelmélete. AZ ELTE BTK Filozófiai Intézete és Nyelvfilozófiai Kutatócsoportja által 2000. október 5-én és 6-án rendezett Nyelv, megértés, interpretáció - A nyelv mint a kortárs filozófiai áramlatok közös problémája c. konferencián tartott előadás. http://mek.niif.hu/00500/00587/html/\#3.

Nyíri Kristóf (2001a): Az írásbeliségről és néhány új médiumról. In: Béres I.-Horányi Ö. (szerk.): Társadalmi kommunikáció. Osiris K. 117-128.p.

O'Hara K, Perry M.,Sellen, A.,Harper R. (2001): Dealing With Mobility: Understanding Access Anytime, Anywhere. INTERACTIONS -NEW YORK- no. Nov/dec. 
O'Dwyer, L., Russell, M., Bebell, D. és Tucker-Seeley, K. R. (2008): Examining the Relationship between Students' Mathematics Test Scores and Computer Use at Home and at School. The Journal of Technology, Learning, and Assessment, 6. 5. sz.

Ollé, János, Papp-Danka, Adrienn, Lévai, Dóra, Tóth-Mózer, Sz.ilvia, Virányi, Anita (2013): Oktatásinformatikai módszerek: Tanitás és tanulás az információs társadalomban. ELTE Eötvös Kiadó. Budapest

Ong, Walter J. (1982): Orality and Literacy: The Technologizing of the Word. London, Methuen.

Orosz Csaba, Havasi Tamás, Gaul Emil és Tóth Tibor (megjelenés alatt): Digitális kultúra a kortárs képzőmüvészetben és a müvészetpedagógiában. Iskolakultúra, közlésre elfogadva: 2017 november.

Krüger P.E., J. Campheri, C.E. Smit: The role of visual skills and its impact on skill performance of cricket players. African Journal for Physical, Health Education, Recreation and Dance (AJPHERD), Vol. 15, No. 4 2009, pp. 605-623.

Paivio, Allan (1971): Imagery and Verbal Processes, Holt, Rinehart and Winston. New York

Pallag Andrea (2006): A megújult érettségi vizsga lehetőségei a rajz és vizuális kultúra tantárgy számára, In.: Horváth Zs., Lukács J. (szerk.): Új érettségi Magyarországon. Országos Közoktatási Intézet, Budapest. 279-294.

Panofsky, E. (1955/1984 [1955]): A jelentés a vizuális müvészetekben. Gondolat Kiadó, Budapest.

Pásztor Attila (2016): Az induktív gondolkodás technológia alapú mérése és fejlesztése. SZTE, DI, Szeged.

Pataky Gabriella (2012): Vizuális képességek fejlödése 6-12 éves korban, a tárgykultúra területén. ELTE TÓK, Budapest

Peternák Miklós (1989): Új képkorszak határán. A számitógépes grafika és animáció kezdetei Magyarországon. Számítástechnika-Alkalmazási Vállalat, Budapest.

Peternák Miklós (1992): A kép a camera obscurától a computerig. In Kárpáti Andrea (szerk.): Bevezetés a vizuális kommunikáció tanitásába. Budapest, Nemzeti Tankönyvkiadó Rt., 47-59. p.

Peternák Miklós (1993): Új képfajtákról; Intermédia, Balassi Kiadó; Budapest

Piaget, J. (1966/1999): Gyermeklélektan. Osiris Kiadó, Budapest.

Piaget, J.(1978): Szimbólumképzés a gyermekkorban. Gondolat. Budapest

Piper, D. (1984): A müvészet élvezete. Helikon Kiadó, Budapest.

Pléh Csaba (2003): A természet és a lélek. Osiris, Budapest

Pléh Csaba, Kovács Gyula, Gulyás Balázs (szerk.) (2003): Kognitiv idegtudomány.

R. Tóth, Krisztina (2015): Felső tagozatos diákok papír-ceruza és számítógép alapú teszteredményeinek összehasonlitó vizsgálata szövegértés, induktív gondolkodás és problémamegoldás terén (Doctoral dissertation). Retrieved from http://www.citefast.com/styleguide.php?style=APA\&sec=Thesis

Read,Herbert (1944): The education of free men. London, Freedom Press

Rock, I., Palmer, S. (1990): The legacy of gestalt psychology. Scientific American, 238, 84 90.

Róka Jolán (2002): Kommunikációtan. Fejezetek a kommunikáció elméletéből és gyakorlatából. Budapest, Századvég Kiadó

Rosengreen, Karl, Erik (2004): Kommunikáció. Typotex, 259. p Budapest,.

Rouma Georges (1908): Notes pédagogiques sur una classe d'enfants anormaux. París : Librairie Henry Paulin \& Cie.

Rusbult, C. E. (1995): Visual thinking and visual-verbal communication. American Scientific Affiliation, http://www.asa3.org/asa/education/teach/visual.htm

S. Nagy Katalin (2013): Képzömüvészet és kommunikáció. Typotex Kiadó, Budapest 
Sándor Zsuzsa (2003): A vizuális nyelv képi világa. Miskolci Egyetemi Kiadó, Sárospatak

Sándor Zsuzsa (2011): Vizuális alkotástípusok a kommunikációban. A vizuális kommunikáció változatainak összehasonlitó elemzése. PhD értekezés. Pécsi Tudományegyetem, Nyelvtudományi Doktori Iskola, Kommunikáció Doktori Program

Schneckenburger, Ruhrberg, Fricke, Honnef (2005): L'art au XXe siecle. Köln, Taschen

Schönau, D. W. (2012): Towards developmental self-assessment in the visual arts: Supporting new ways of artistic learning in schools. International Journal of Education Through Art, 8(1) 49-58.

Schuster, Martin (2005): Müvészetlélektan. Képi kommunikáció - Kreativitás - Esztétika. Panem Kiadó, Budapest

Searle, John R. (2003): A képi reprezentáció. In Horányi Özséb (szerk.): A sokarcú kép. Válogatott tanulmányok a képek logikájáról. Typotex, Budapest, 205-225.

Sekuler, R. és Blake, R. (2000): Észlelés. Osiris, Budapest

Selfe, Lorna (1983): Normal and Anomalous Representational Drawing Ability in Children. Hardcover - 1860

Simon Tünde (2015): A vizuális kommunikáció képességcsoportjának értelmezése és fejlődése 10-12 éves korban. Iskolakultúra 25. évf. 15/02. sz. 32-47.

Simon Tünde (2015): Az észt információs társadalom és oktatási rendszere. Országtanulmány. Infonia 2015/4

Smith, Kenneth Louis (2005). Handbook of Visual Communication: Theory, Methods, and Media. p.123.

Souza, B. C. (1998): Creativity and problem solving: elements for a model of creativity, CogPrints, http://cogprints.org/1426/00/creatmodel.htm

Steers, John (2009): Creativity: Delusions, Realities, Opportunities and Challenges.International Journal of Art \& Design Education, Volume 28, Issue 2, pages 126-138,

Stegman, Petra (2007): Fluxus East. In: Petra Stegman (szerk.): Fluxus East. FluxusNetzwerke in Mittelosteuropa / Fluxus Networks in Central Eastern Europe. (kat.), Künstlerhaus Bethanien, Berlin, 5-52.

Steiner, Rudolf (1992): Szabadságra nevelés. Török Sándor Waldorf Ped. Al. Budapest

Strohner József (2005): Társadalmi szerepek a vizuális kommunikáció folyamataiban és a vizuális nevelés. Magyar Pedagógia 105. évf. 3. szám 283-305.

Szabó Gábor, Kardos János (2014): Képalkotás. Typotex Kiadó

Szalontai György (1994): Vizuális nevelés. Tárogató Kiadó, Budapest.

Szecskő Tamás (1994): A tömegkommunikáció társadalmi hatásai. Bevezetés a tömegkommunikáció szociológiájába. Oktatáskutató Intézet, Budapest

Székácsné Dr. Vida Mária (1982): A rajz tanítása. Tankönyvkiadó, Budapest

Terestényi Tamás (2006): Kommunikációelmélet. A testbeszédtöl az internetig. AKTI Typotex Kiadó, Budapest.

Tongori Ágota (2012): Az IKT-müveltség fogalmi keretének változása. Iskolakultúra_201211_034-047

Tóth Alisa, Kárpáti Andrea és Molnár Gyöngyvér (2017): A színpercepció és a színértelmezés online mérésének lehetőségei kisiskolás korban, Magyar Pedagógia. 117. évf. 4. szám 399-421.

Tóth Péter (2006): A hazai rajzoktatás története a népoktatási törvényig. A rajziskolák. Neveléstörténet. 1-2, o. n.

Tóth Péter (2008): Integrált elektronikus tanulási környezet. In: Dr. Benedek András (szerk.): Digitális pedagógia - Tanulás IKT környezetben. Typotex, 2008. 
Tóth-Mózer Szilvia, Kárpáti Andrea (2016). A digitális kompetencia kognitív dimenziója és összefüggésrendszere egy empirikus kutatás tükrében. Magyar Pedagógia, 116:(2) 121150. www.magyarpedagogia.hu/document/Toth-Mozer_MPed20162.pdf

Töreky Ferenc (2002): Vizuális kommunikáció. Nemzeti Tankönyvkiadó, Budapest

Trencsényi László (1999): Az alternatív pedagógiák nyomában. Iskolakultúra 1999/5.

Trencsényi László (2005): A tartalmi szabályozás hosszú története. Egy szemtanú magamentsége. In: Loránd Ferenc (szerk.): A tantervi szabályozásról és a bolognai folyamatról 2003-2004. Oktatási Minisztérium, Országos Köznevelési Tanács, Budapest. 37-44.

Tufte, Edward R. (2006): Beautiful evidence. Cheshire, Conn. Graphics Press

Urban, Klaus K. (2005). Assessing Creativity: The Test for Creative Thinking-Drawing Production (TCT-DP). International Education Journal, (6)2, 272-280.

Varga Emőke (2012): Az illusztráció a teóriában, a kritikában, az oktatásban. L’Harmattan Kiadó, Budapest.

Vass Zoltán (2006). A rajzvizsgálat pszichodiagnosztikai alapjai. Flaccus Kiadó, Budapest

Vig Zoltán (2008): Az oktatás IKT környezete. In: Dr. Benedek András (szerk.): Digitális pedagógia - Tanulás IKT környezetben. Typotex. Budapest.

Wagner, E. és Schönau, D. (éd., ed., Hrsg.) (2016): Cadre Européen Commun de Référence pour la Visual Literacy - Prototype. Common European Framework of Reference for Visual Literacy - Prototype. Gemeinsamer Europäischer Referenzrahmen für Visual Literacy - Prototyp. Münster-New York: Waxmann

Waters S.D., Pommerich M. (2007). Context effects in internet testing: A literature review. Conference Paper. 2007.04.07. New York City

Way, W. D., Davis, L. L. és Fitzpatrick, S. (2006): Practical questions in introducing computerized adaptive testing for K-12 assessments. Pearson, San Antonio.

Wittgenstein Ludwig (1989): Logikai-filozófiai értekezés. Akadémiai Kiadó,. 4.01, 4.016, 4.02. Budapest

Zombori Béla (1995): A vizuális nevelés új dimenziói. In: Kárpáti Andrea (szerk.): Bevezetés a vizuális kommunikáció tanitásához. Nemzeti Tankönyvkiadó, Budapest, 125-139 


\section{Mellékletek}

\section{Sz. melléklet}

A feladatok elnevezése a tartalomra utal. A feladat neve végén szereplő számok jelzik, melyik évolyam végezte el a feladatot (pl. a „piktogram_45” elnevezésű feéadat itemeit a 4. és 5. évfolyam oldotta meg). A feladatok közlésében elöre rendeztük azokat a feladatokat, melyeket mindhárom évfolyam megoldott. Ezt követően évfolymaonként közöljük a feladatokat.

13. feladat

\section{(2))}

Olvasd el a mesét a Pontról!

Melyik kép ábrázolja a Pont mozgását?

A képre kattintva jelöld válaszod!

\section{1))}

Egyszer volt, hol nem volt, volt egyszer egy Pont. Életre kelt és elindult a papíron. Ment, mendegélt, majd megállt, tétován körbe tekintett, azon gondolkodva, merre induljon. Eldöntötte az irányt, és vidáman ugrándozva ment tovább. Egy folyó állta útját, melynek vizében úszott. Mikor kijött a vízböl, föl-alá futkározott, hogy megszáradjon. Ekkor találkozott egy társával, akivel együtt folytatta útját.
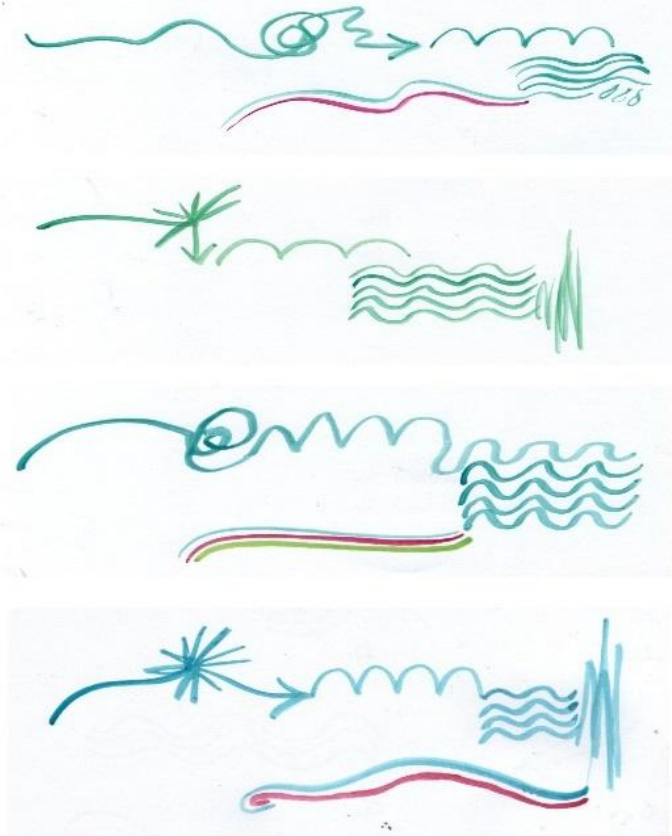

Elöre

1. feladat Pontmozgasa_456 
15. feladat 0$)$

A képek egy-egy dallamnak, ritmusnak a kép-párjai.

Hallgasd meg a zenéket és párosítsd a hangokat a képekkel!

Minden képhez csak egy hangsor társítható és az egyiknek nincs párja!
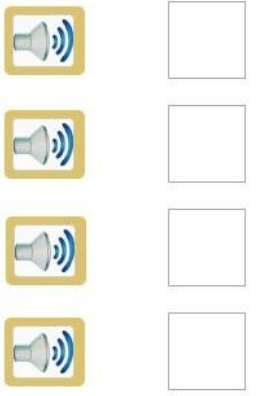

4.

2.
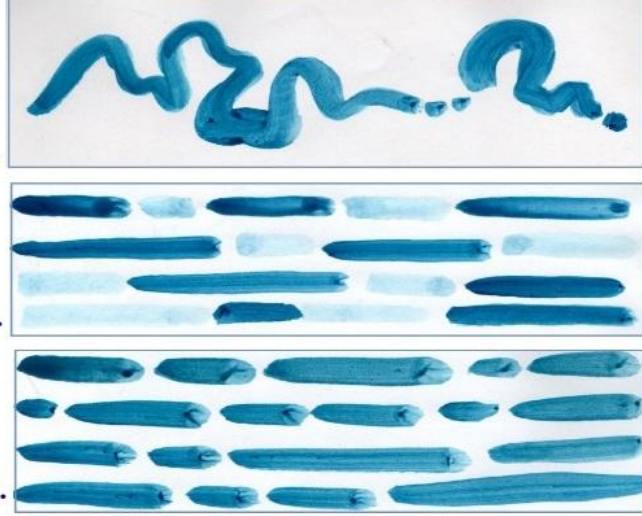

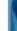

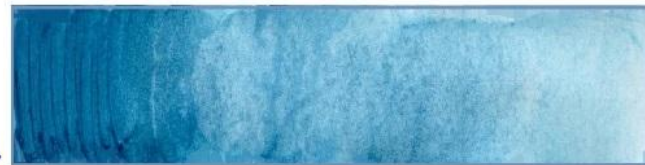

0000000000000

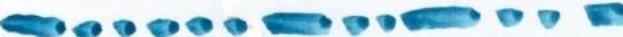

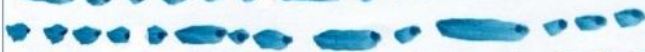

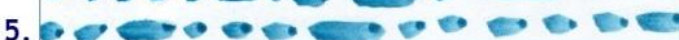

16. feladat $(2))$

A képek egy-egy dallamnak, ritmusnak a kép-párjai.

Hallgasd meg a zenéket és párosítsd a hangokat a képekkel!

Minden képhez csak egy hangsor társítható és az egyiknek nincs párja!

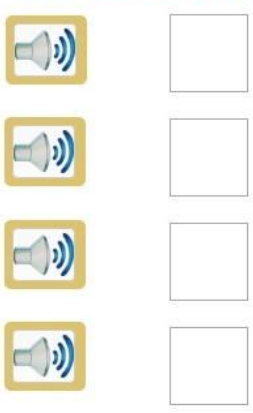

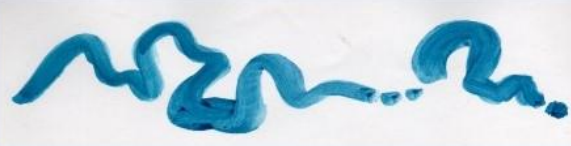

2.

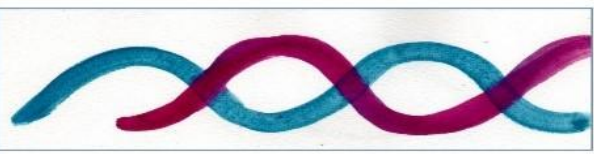

-0000000000000 200000 $-00,0000$

3. $0=0,00000$

4.

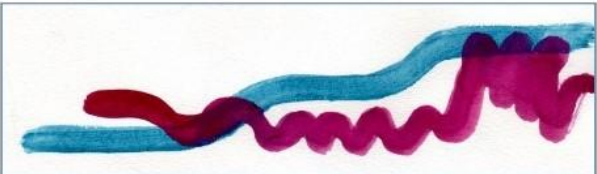

5.

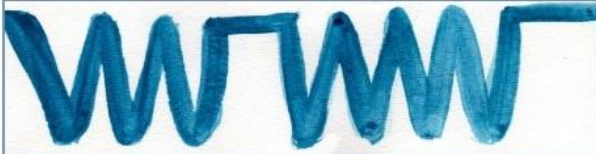

Elöre -

3. feladat Zene2_456 
16. feladat

1)) Párosítsd az ábrákat a felsorolt szavakkal!

A választott kifejezés betűjelét írd a megfelelő kép alatti négyzetbe!

W Minden szóhoz egy kép tartozik, és egy szónak nincs párja.
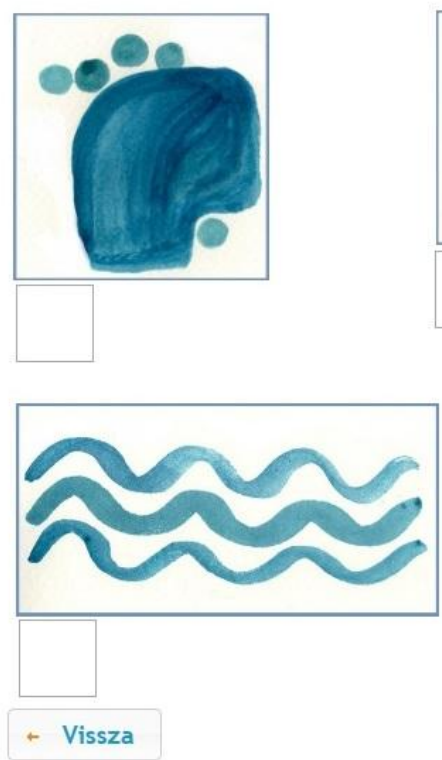
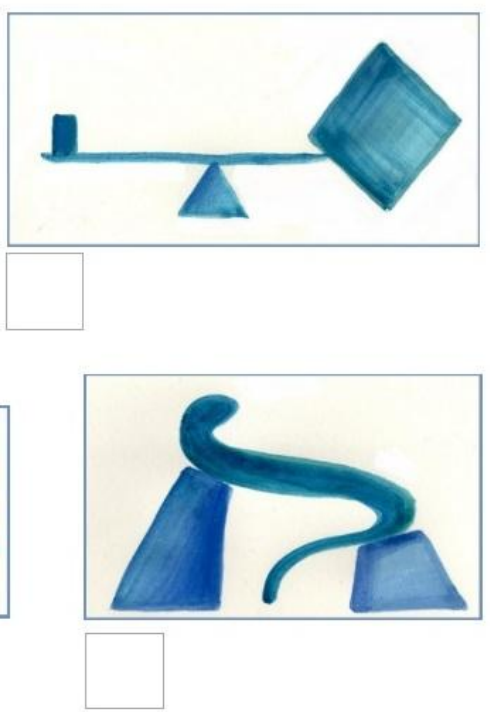

4. feladat Szavakesabrak3_456

\section{8. feladat}

๑) Párosítsd a rajzokat a szövegben jelölt kifejezésekkel! Válaszd ki a kifejezések utáni legördülő listából a megfelelő ábra betűjelét!

ঔMinden ábrához csak egy meghatározás tartozik és egy ábrának nincs párja.

(1)) Egyszer volt, hol nem volt, volt egyszer egy Pont. Életre kelt és elindult a papíron. Ment, mendegélt, Válassz! • majd megállt, tétován körbe tekintett Válassz! • , azon gondolkodva, merre induljon. Eldöntötte az irányt Válassz! • és vidáman ugrándozva ment Válassz! v tovább. Egy folyó állta útját, melynek vizében úszott. Mikor kijött a vízből, föl-alá futkározott, hogy megszáradjon. Ekkor találkozott egy társával, akivel együtt folytatta útját Válassz! ·

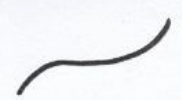

a.

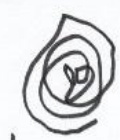

b.

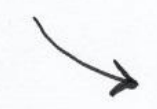

6.

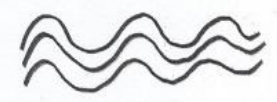

d.
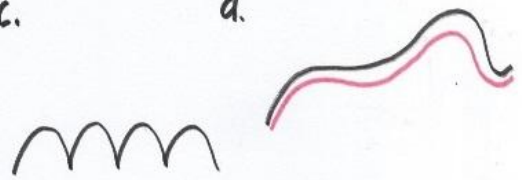

e.<smiles>C1CC2(C1)CC2</smiles> 


\section{3. feladat}

๑) A) A térkép három kalóz (Piros, Kék, Zöld) útjait ábrázolja. Az ábra alapján dönts el, igazak vagy hamisak az állítások!

Az állitások utáni négyzetbe írj egy "h" betüt, ha hamis vagy egy "i" betüt, ha igaz!

\section{A) (1)}

- Minden kalóz volt a Banánszigeten.

- A Kék Kalóz találkozott a bálnával.

- A Zöld Kalóz a Banánszigeten fejezte be útját.

- A Polippal nem találkoztak

- A Kék Kalóz négyszer kötött ki.

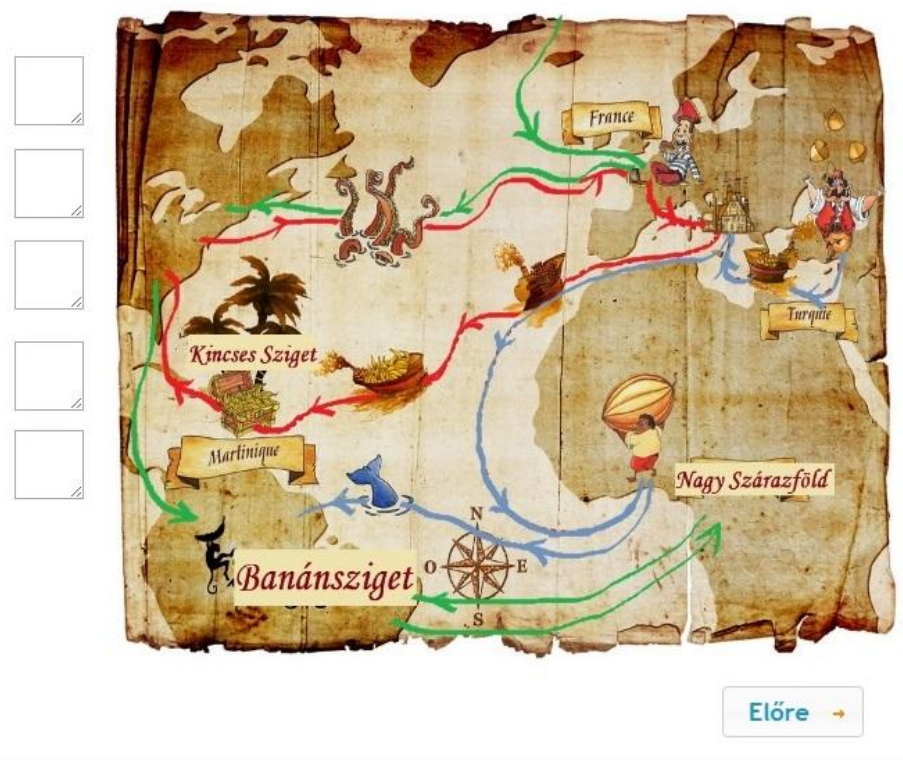

6. feladat Terkep_456

1. feladat

(1)) Mit jelentenek a következő ábrák?

Párosítsd a meghatározásokat az ábrákkal!

Írd a meghatározás melletti négyzetbe a választott ábra számát!

¿ Egy ábrának nincs párja.

1)) Ne zavarják az állatokat!

Tüzet gyújtani tilos!

Füre lépni tilos!

Virágot letépni tilos!

Ne zajongjanak!

Ne lépjenek a vízbe!

Szemetet eldobni tilos!

Vissza
1.

2.
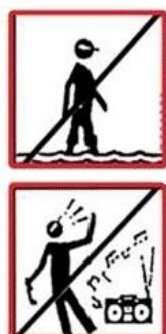

5.

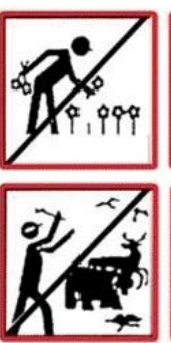

6.
3.
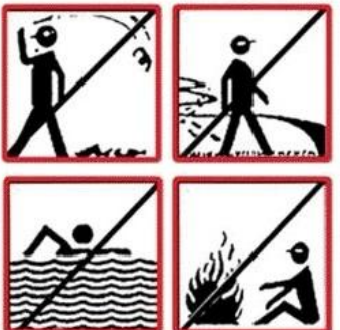

7.

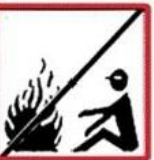

8.

Elöre - 
(j))

A királyfi a gonosz sárkánnyal szeretne megvívni. A harc előtt egy rajzos figyelmeztető üzenetet kap jóakaróitól.

Mit jelent a rajz? Válaszd ki a felsoroltak közül!

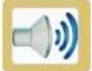

- A sárkány legyőzhető

- Étkezéssel jön meg a sárkány ereje

- Csak reggel érdemes harcba bocsátkozni a sárkánnyal

- Ha jóllakott, akkor veszélytelen

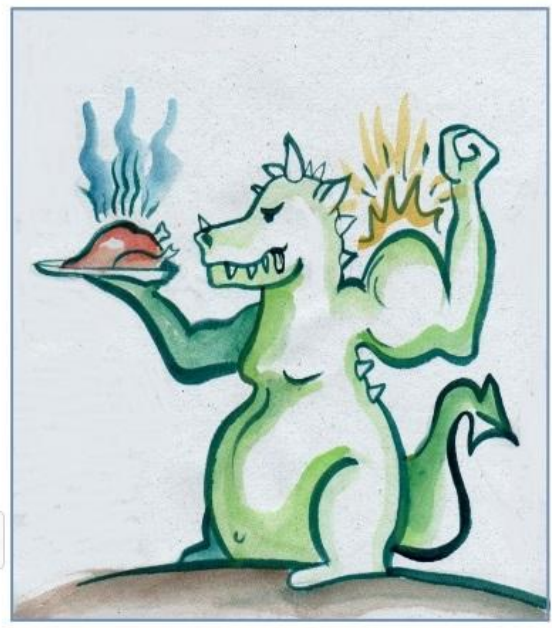

8. feladat Sarkany_4

\section{3. feladat}

†)) Az illusztrációk a „Varázsló Benedek Nemszeretem országban” című meséből valók.

Párosítsd a mondatokat a rajzokkal! Írd a választott mondat számát a képen található négyzetbe!

W Minden képhez egy mondat tartozik és egy mondatnak nincs párja.
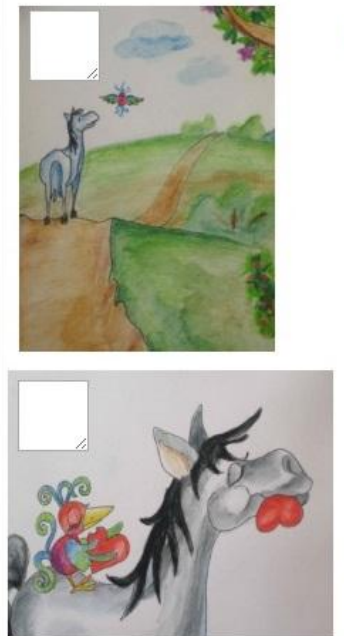

- Vissza
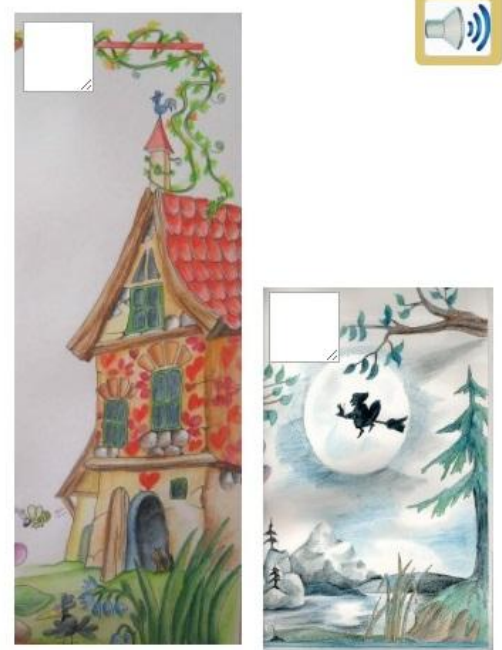

1. Jóízűen falatozták a ház darabkáit.

2. A ház az éppen akkor hazatérő boszorkányé volt.

\section{Varázsló Benedek és Ezerszínű} Eufrozina együtt folytatták útjukat.

4. Egy mézeskalácsból készült házat pillantottak meg a vadonban.

5. A boszorkány vendégül látta őket.

\section{9. feladat Varazslobenedek_4}




\section{5. feladat}

( )) Színezd ki a virág fehér szirmát azzal a színnel, amelyik kikeveréséhez sárgát is használnunk kellett!

Kattints először a választott színre, majd a virágsziromra! A radírral törölhetsz is.
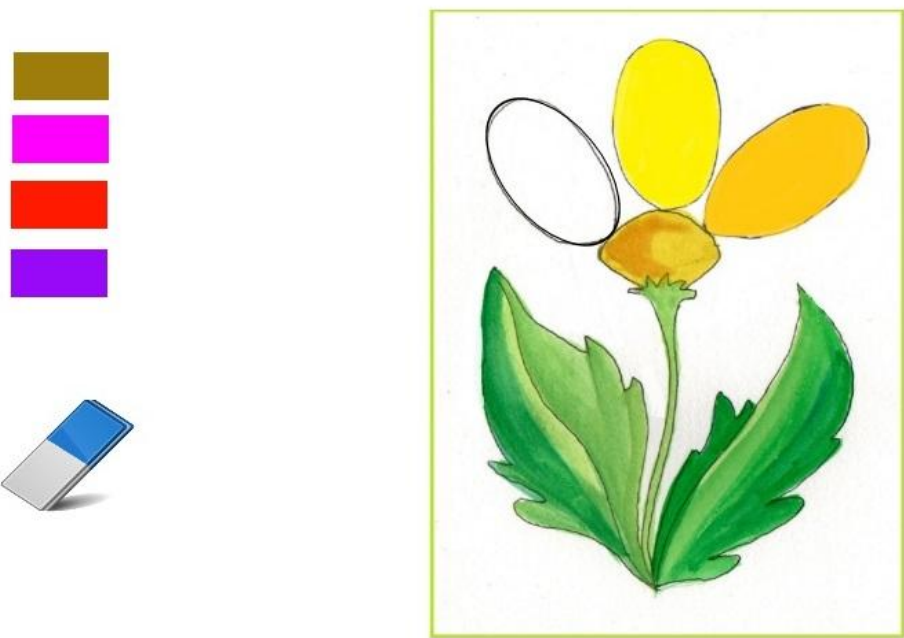

10. feladat Szinkeveresharomszirmuvirag_4

\section{6. feladat}

1)) Színezd ki a gyöngysor fehér szemeit úgy, hogy balról jobbra $(\Rightarrow)$ egyre sötéttebb árnyalatot válassz! Minden árnyalatot egyszer használhatsz!

Kattints először a választott színre, majd a gyöngyre!

A radírral törölhetsz is.
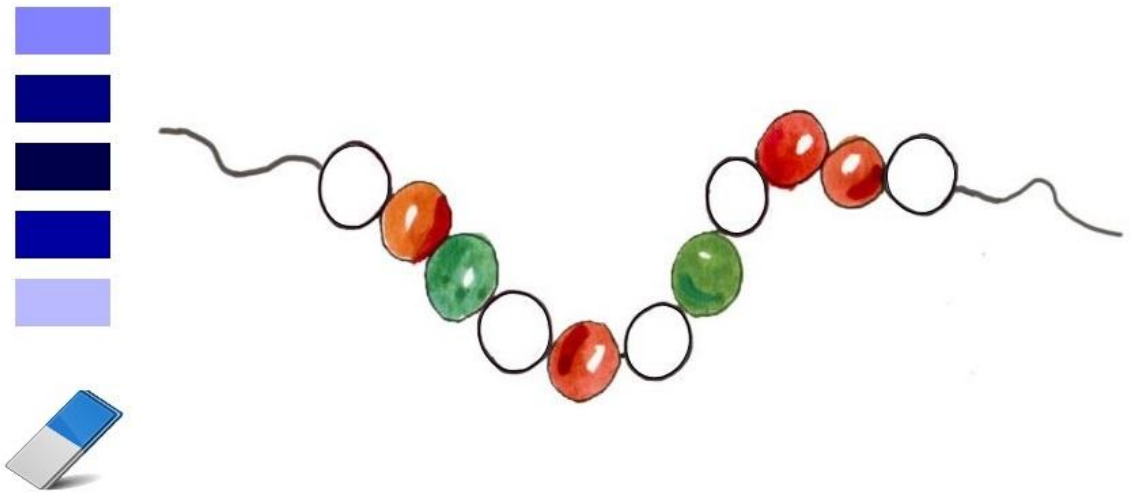


\section{7. feladat}

1)) Rendezd helyes sorrendbe a bukfencező lányról készült képeket!

A képekre kattintva jelöld a sorrendet! A sorszámot visszavonhatod, ha újra kattintasz a jelölésedre.
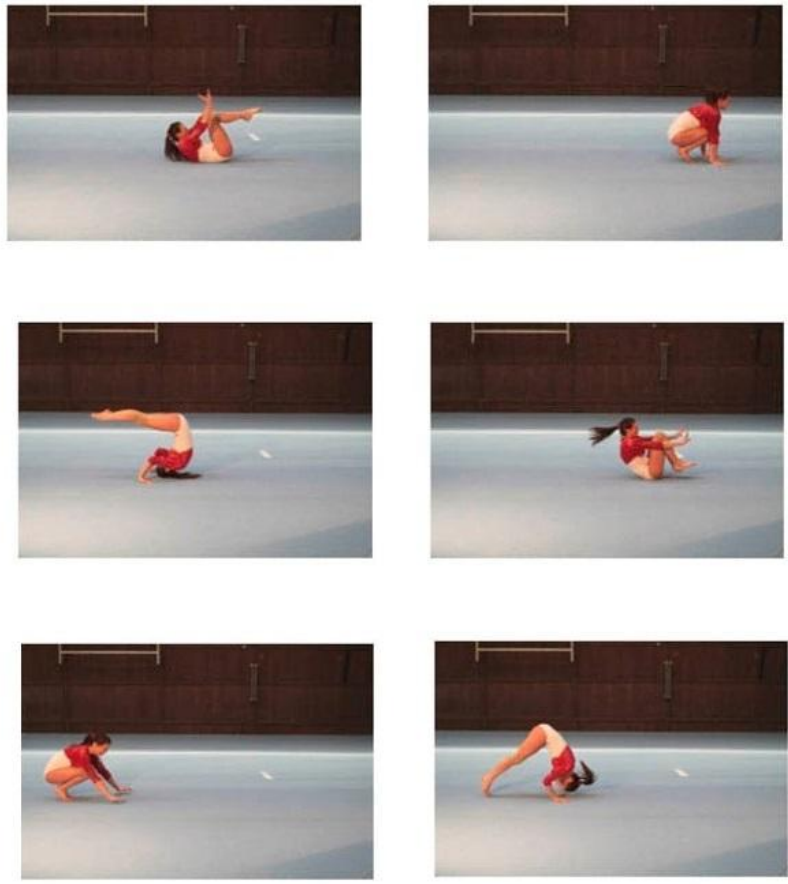

8. feladat

\section{(5))}

Melyik Keith Haring képhez tartozik az alábbi darab?

Válaszod a képre kattintva add meg!
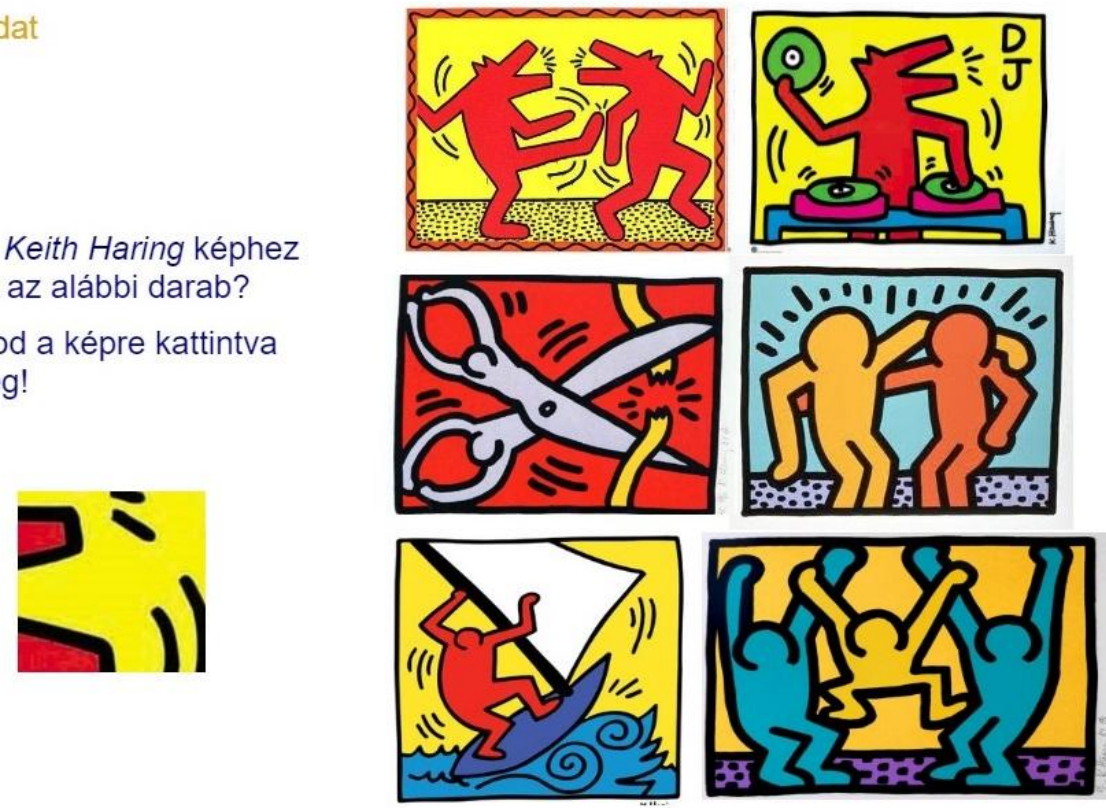


\section{9. feladat}

๑) Melyik kép hiányzik az alábbi két képhez, hogy a három kép együtt a "Télapó"-t jelentse?

Válaszd ki a jobb oldalon lévő képek közül, és húzd az üres négyzetbe!
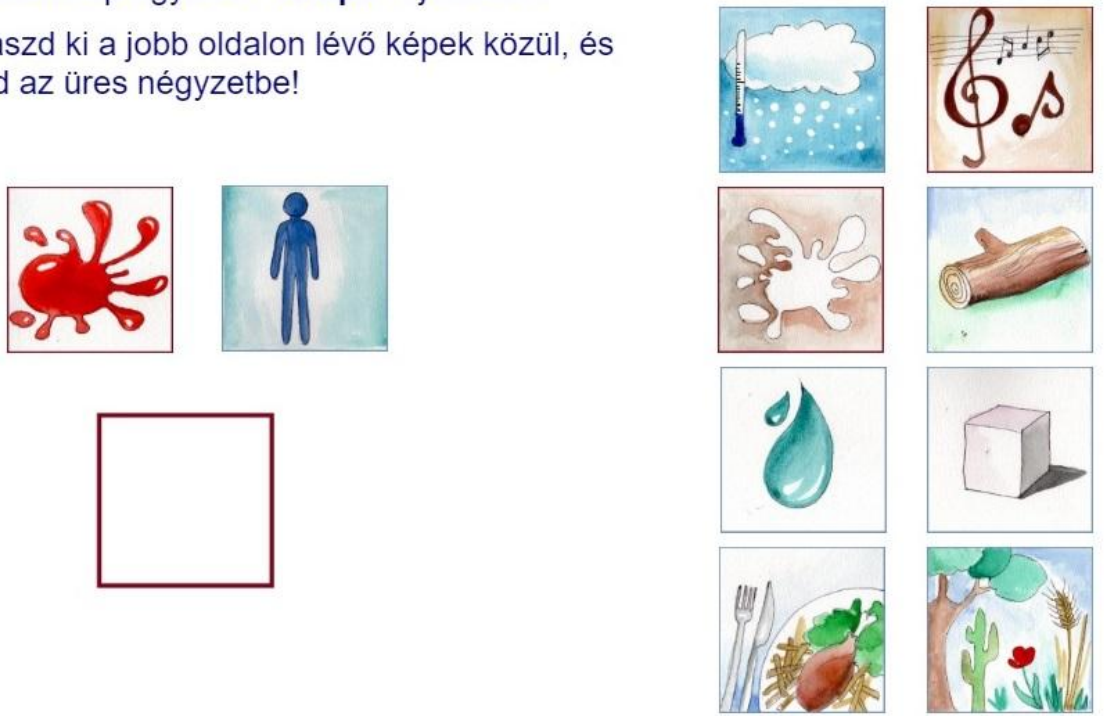

A képeken különböző lakásrészleteket látsz. Hideg vagy meleg érzetet keltő színhatásuk alapján sorold őket két csoportba!

Minden kép csak az egyik csoportba tartozhat.

Húzd a Hideg vagy a Meleg szót a képekre!

Meleg Hideg
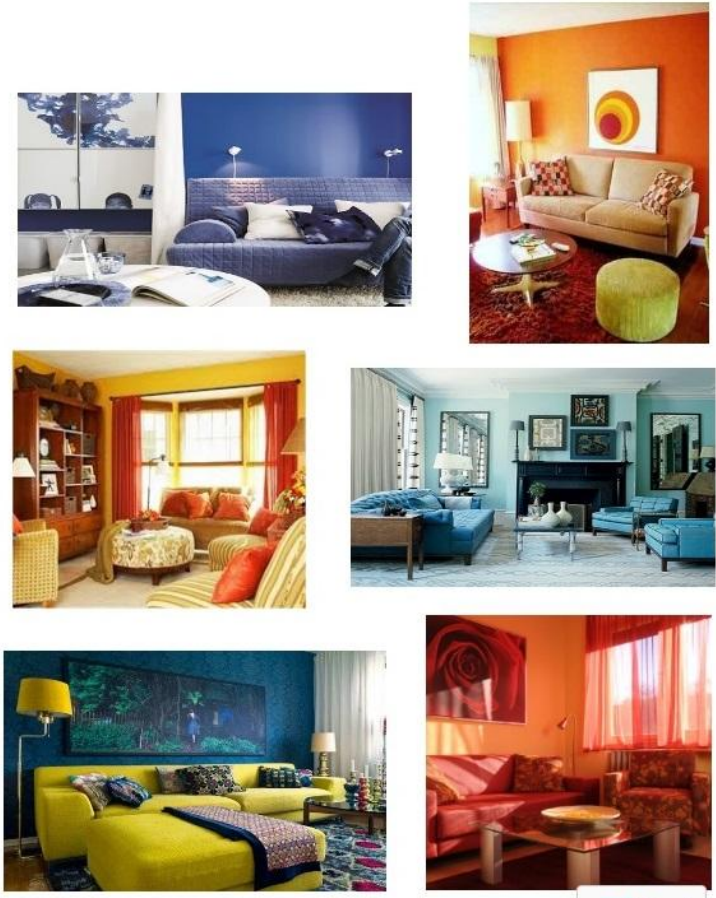

Elöre $\rightarrow$

15. feladat Hokkontraszt_5 


\section{D)}

A köztéri szobrokat télen betakarják, mert védik az időjárás viszontagságaitól.

A csomagolás egy szegedi köztéri szobrot takar. Vajon melyik szobor rejtőzik a lepel alatt? Kattints a kiválasztott szoborra!
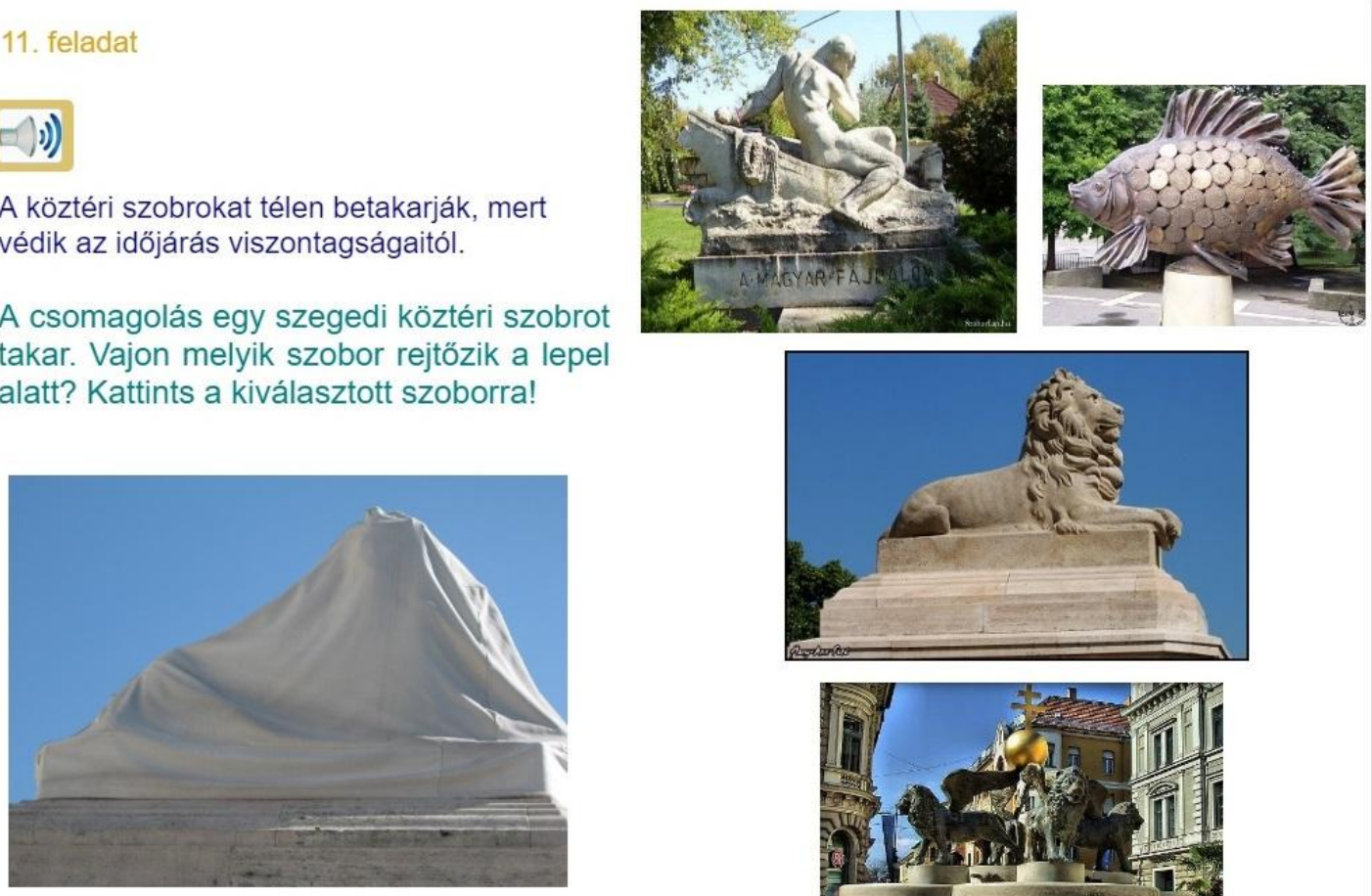

+ Vissza

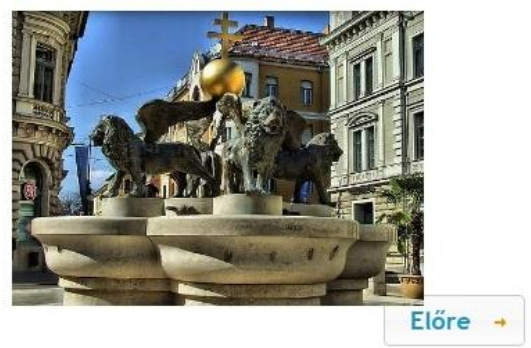

16. feladat Leplekoroszlan_4

\section{2. feladat}

๑) A köztéri szobrokat télen betakarják, mert védik az időjárás viszontagságaitól.

A csomagolás egy szegedi köztéri szobrot takar.

Vajon mely szobor rejtőzik a lepel alatt? Kattints a kiválasztott szoborra!
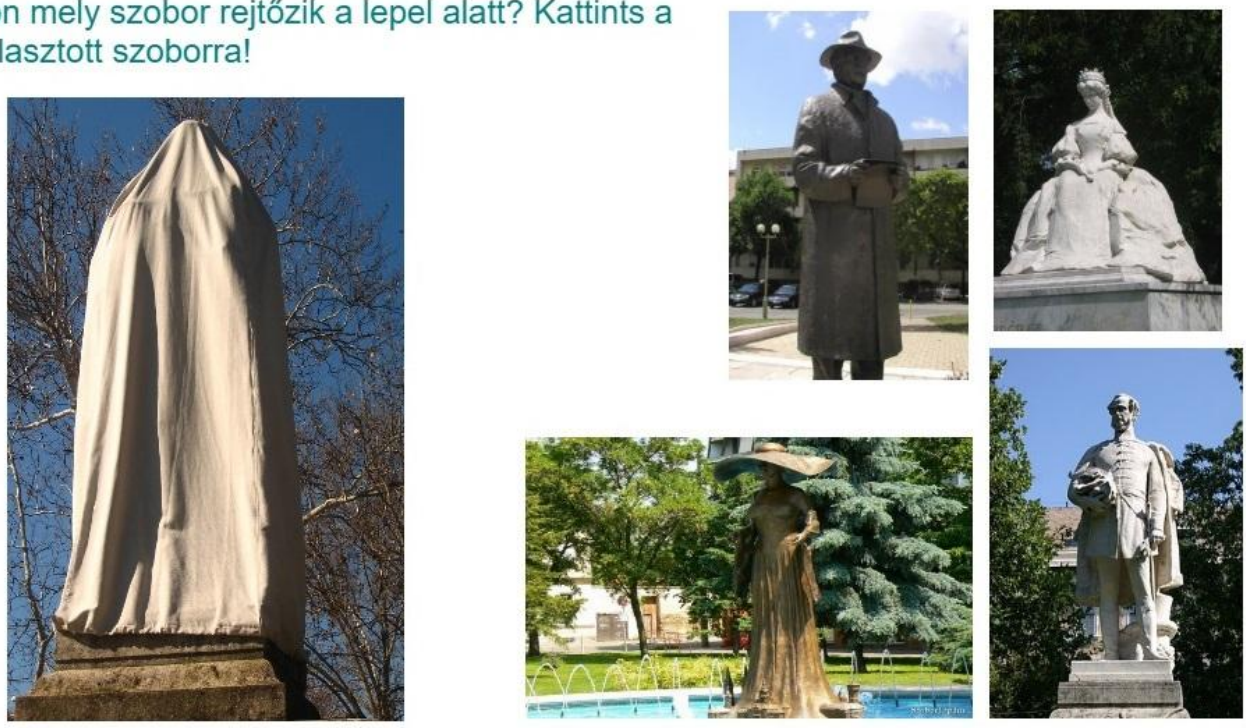

- Vissza

Elöre $\rightarrow$ 
- ग) A fotókon látható gimnazisták műalkotások szereplőinek mozdulatait utánozták.

Keresd meg, melyik kép, melyiknek a párja! Vigyázz, van a képek között tükörkép is!

Írd a képeken található négyzetbe a kiválasztott kép számát!
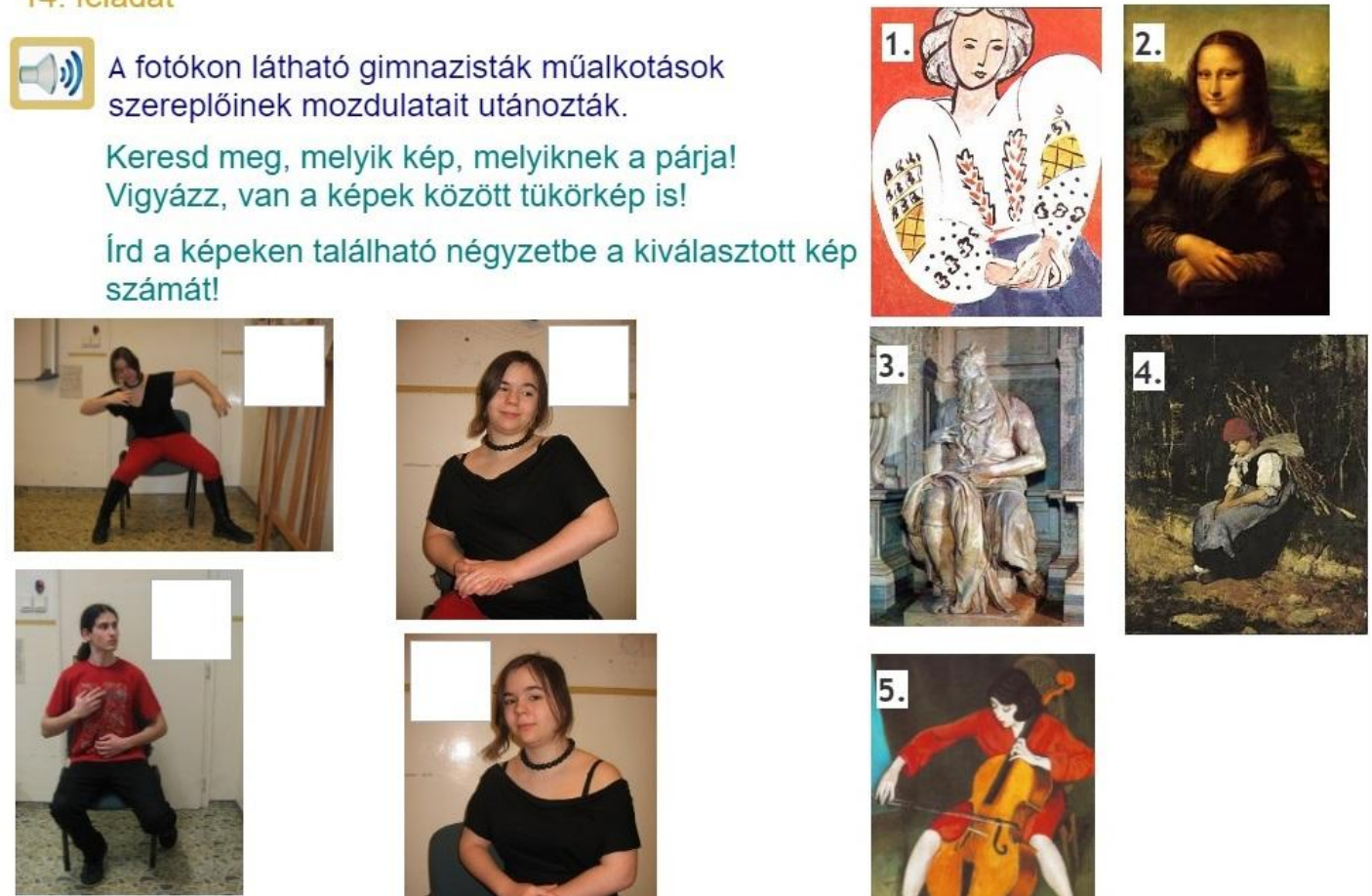

- Vissza
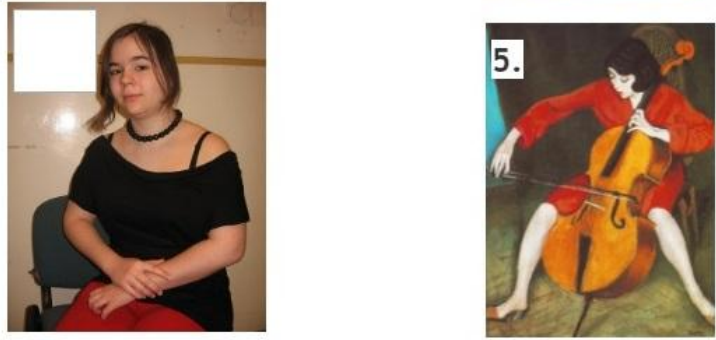

Elöre -

18. feladat Mozdulatok_4

\section{7. feladat}

ग) Olvasd el az alábbi mesét, és válassz a képek közül! Melyik rajz ábrázolja legpontosabban a családi viszonyokat, a szereplők tulajdonságait? Kattints a választott képre!

A rajzokat másodikos gyerekek készitették a királyi családról.

"Hol volt, hol nem volt, volt egyszer egy király és egy királyné, akiknek sorban született három fiuk. Telt-

ग) múlt az idő, a gyerekek felnóttek és feleséget választottak maguknak. A legidósebb királyfi a Virágot Nevetó Királykisasszonyt, a középsó királyfi a Világszép Nádszálkisasszonyt, míg a legkisebb királyfi az Aranyhajú Királykisasszonyt vette feleségül. A legidösebb királyfinak hamarosan született egy fia; a középső királyfi családja szintén egy fiúgyermekkel gyarapodott, a legkisebb királyfiéknál pedig két ikerkislány született.
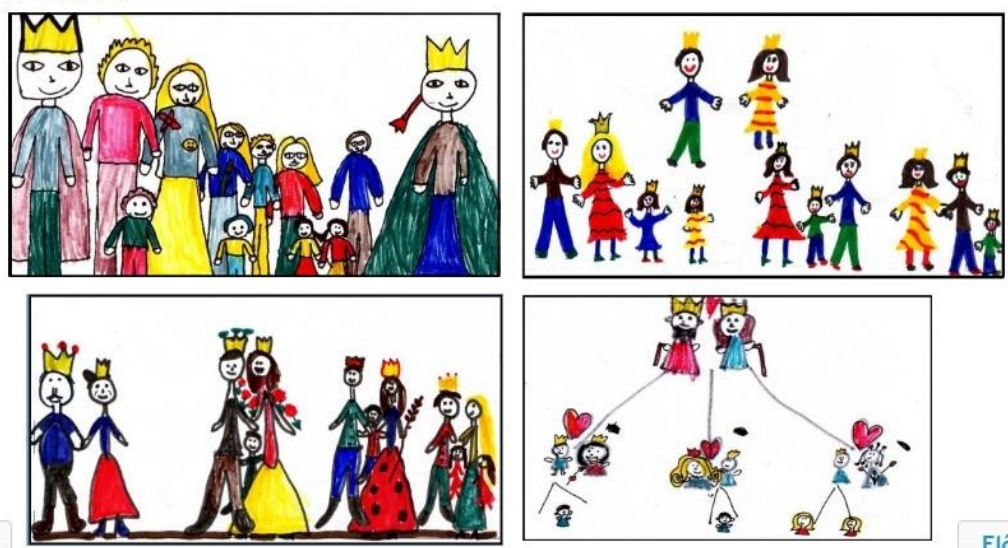

19. feladat Csaladfa_4 


\section{9. feladat}

๑) Párosítsd az ábrákat, ábrázolásokat a felsorolt szavakkal!

A választott kifejezés betűjelét írd a megfelelő kép alatti négyzetbe! Minden szóhoz egy kép tartozik, és egy szónak nincs párja.
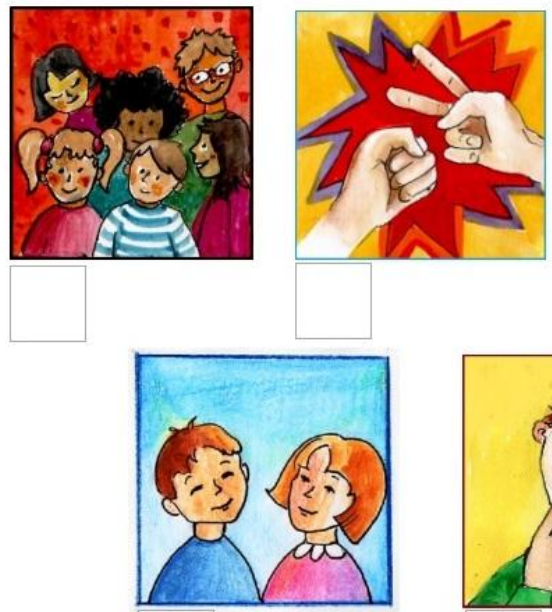

- Vissza

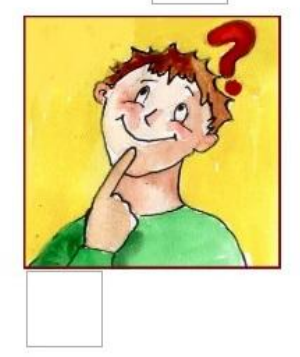

A. Mutogasd el!

B. Gondolkodj!

C. Rajzold le!

D. Vitassátok meg!

E. Páros munka

F. Csoportmunka

20. feladat Szavakesabrak4_4

\section{1. feladat}

1) Figyeld meg Thomas Gainsborough angol festő páros portréját. Melyik a helyes válasz az alábbi kérdésre?

Milyen kapcsolatban lehet a két szereplő egymással?

Barátnők, mert hasonló a ruhájuk.

Nincs köztüik kapcsolat.

Testvérek, mert hasonlitanak egymásra és különbözö korúak

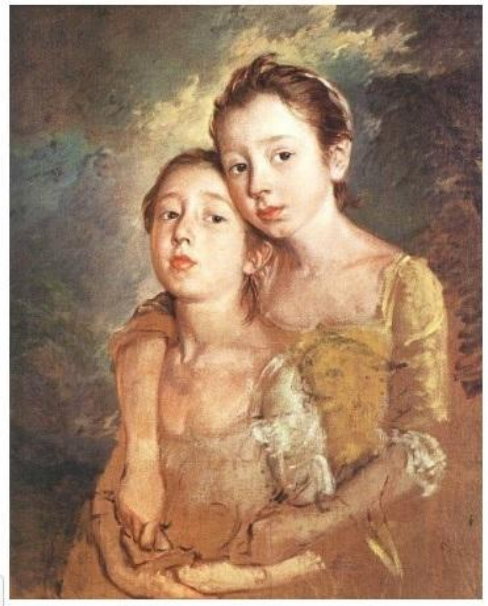

Ellenségek, mert háttal állnak egymásnak. 


\section{9. feladat}

D) A fotók egy gerendagyakorlat végének képeit összekeverve jelenítik meg.

Rendezd helyes sorrendbe a képeket!

A képekre kattintva jelöld a sorrendet! A sorszámot visszavonhatod, ha újra kattintasz a jelölésedre.

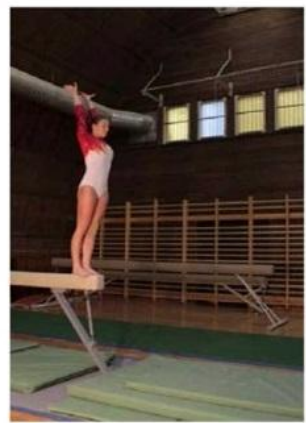

Vissza
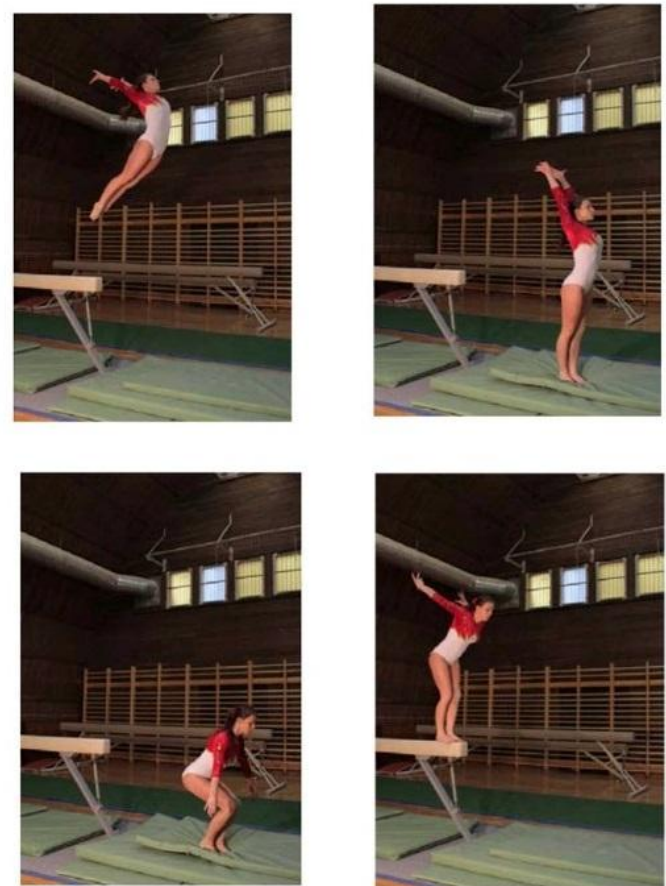

Elöre $\rightarrow$

\section{2. feladat Gerenda_5}

20. feladat

\section{(1))}

A képek a palacsintasütés lépéseit ábrázolják.

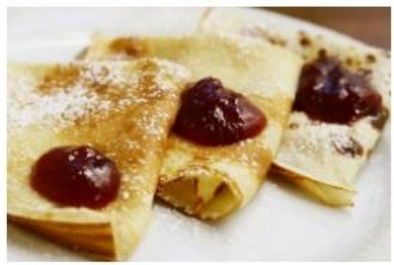

Rendezd helyes sorrendbe a képeket!

A képekre kattintva jelöld a sorrendet! A sorszámot visszavonhatod, ha újra rákattintasz a jelölésedre.
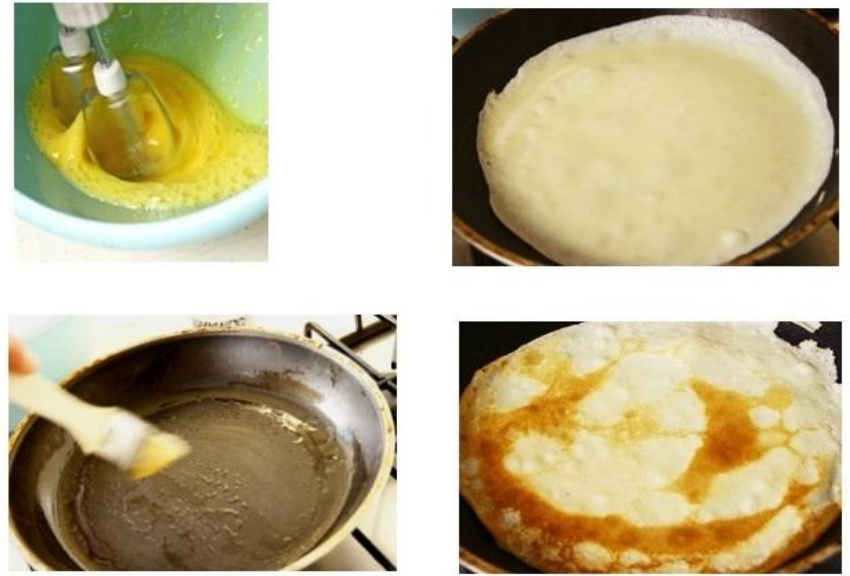


\section{3. feladat}

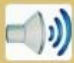
A képeken Pablo Picasso két festményét láthatod.

A.

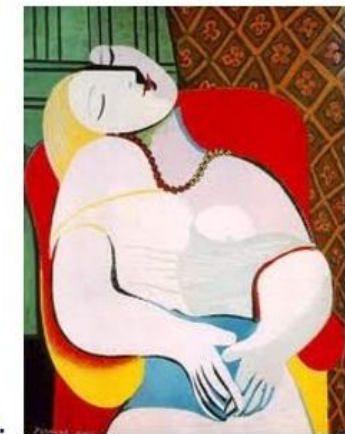

B.

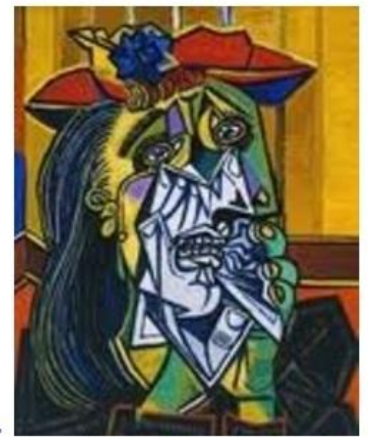

Melyik képre vonatkoznak az állítások? A megfelelő gomb megnyomásával válaszolj!

- Az) érzelmeket a sötét kontúrokkal is kifejezi.

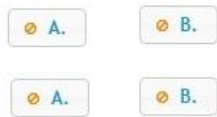

- Világos tónusokkal jeleníti meg a figurát

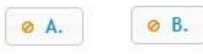

- A kép hangulata békés, nyugodt.

- A festmény címe: Síró nő

- Hullámzó vonalak és gömbölyded formák jellemzik

\section{4. feladat Picasso_56}

\section{2. feladat}

Színezd ki a gyöngysor fehér szemeit úgy, hogy balról jobbra egyre sötéttebb árnyalatot válassz! Minden árnyalatot egyszer használhatsz!

Kattints először a választott színre, majd a gyöngyre!

A radírral törölhetsz is.

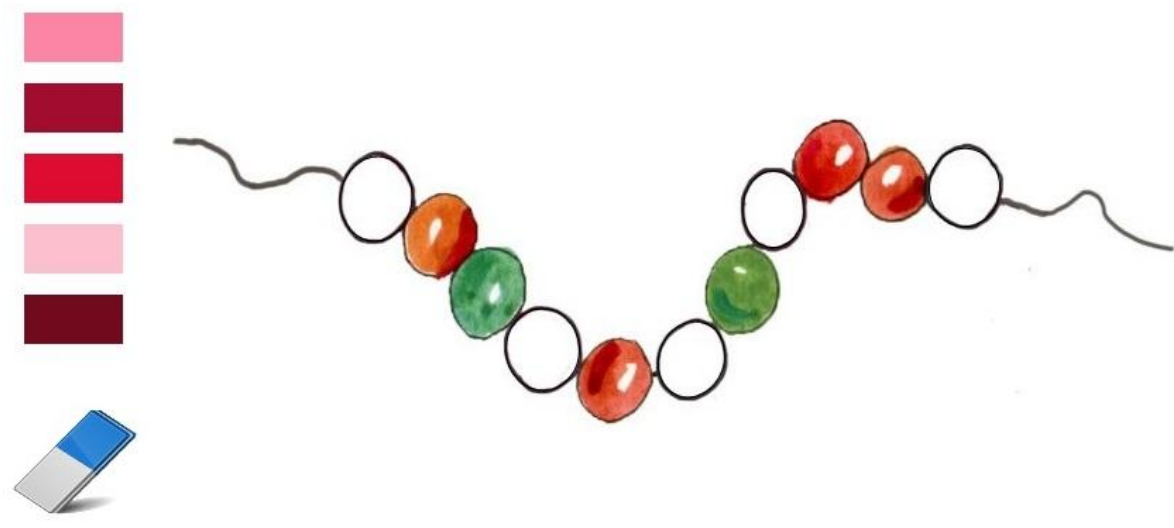




\section{3. feladat}

\section{$5(1))$}

Melyik képhez melyik színskála tartozik?

İrd a kiválasztott színskála számát a megfelelő rajzhoz tartozó négyzetbe!

Yo Minden rajzhoz egy színskála tartozik és az egyik színskálához nem tartozik kép.

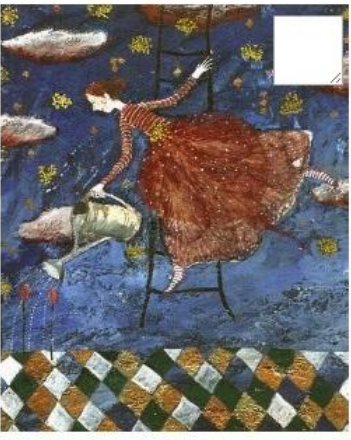

- Vissza

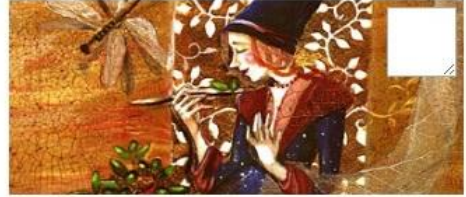

a.
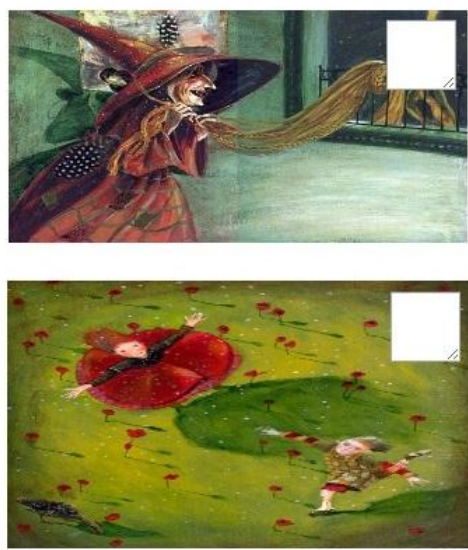

d

e.

Elöre $\rightarrow$

b.

C.

(2)

26. feladat Szinelemzes_56

\section{4. feladat}

(2)) Figyeld meg a színek sötétvilágos árnyalatait!

Kattints arra a szürkeárnyalatos képre, amelyik a színes kép árnyalatokban megfelelő párja!
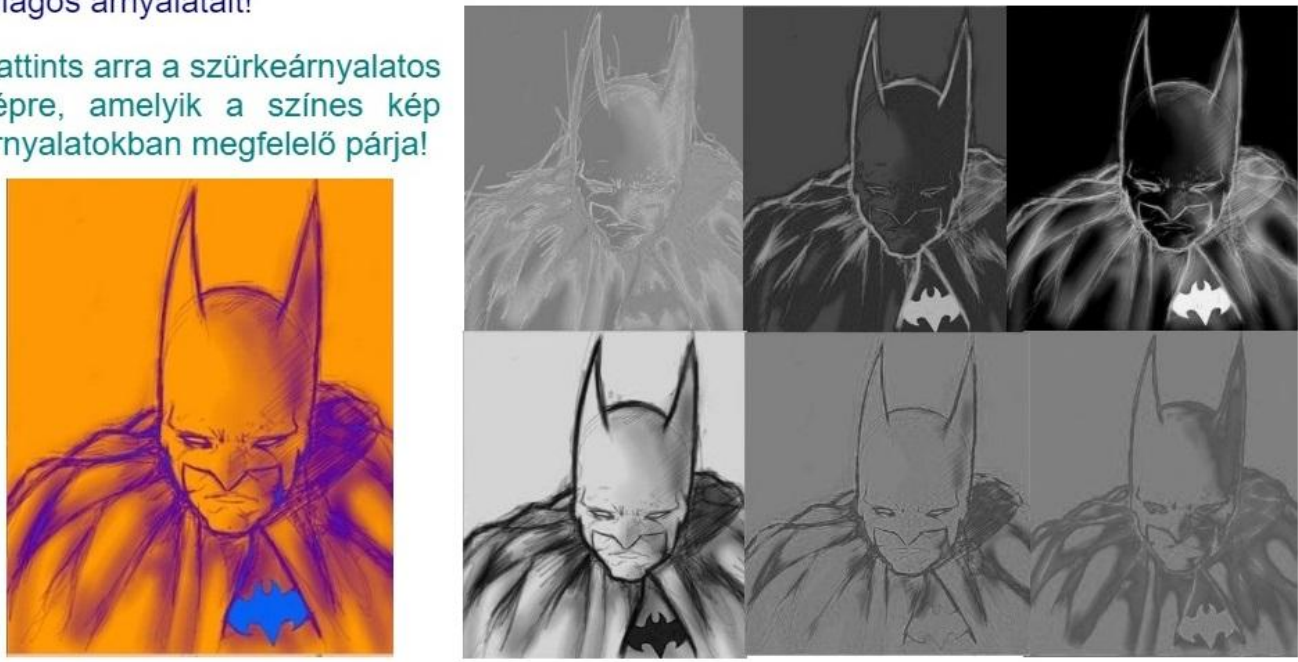

- Vissza 


\section{5. feladat}

\section{D) (1)}

Piet Mondrian holland festő fa-sorozatából válogattunk hatot.

Melyik kép részletét ábrázolja a lenti fekete-fehér átalakítás? Kattints a választott képre!
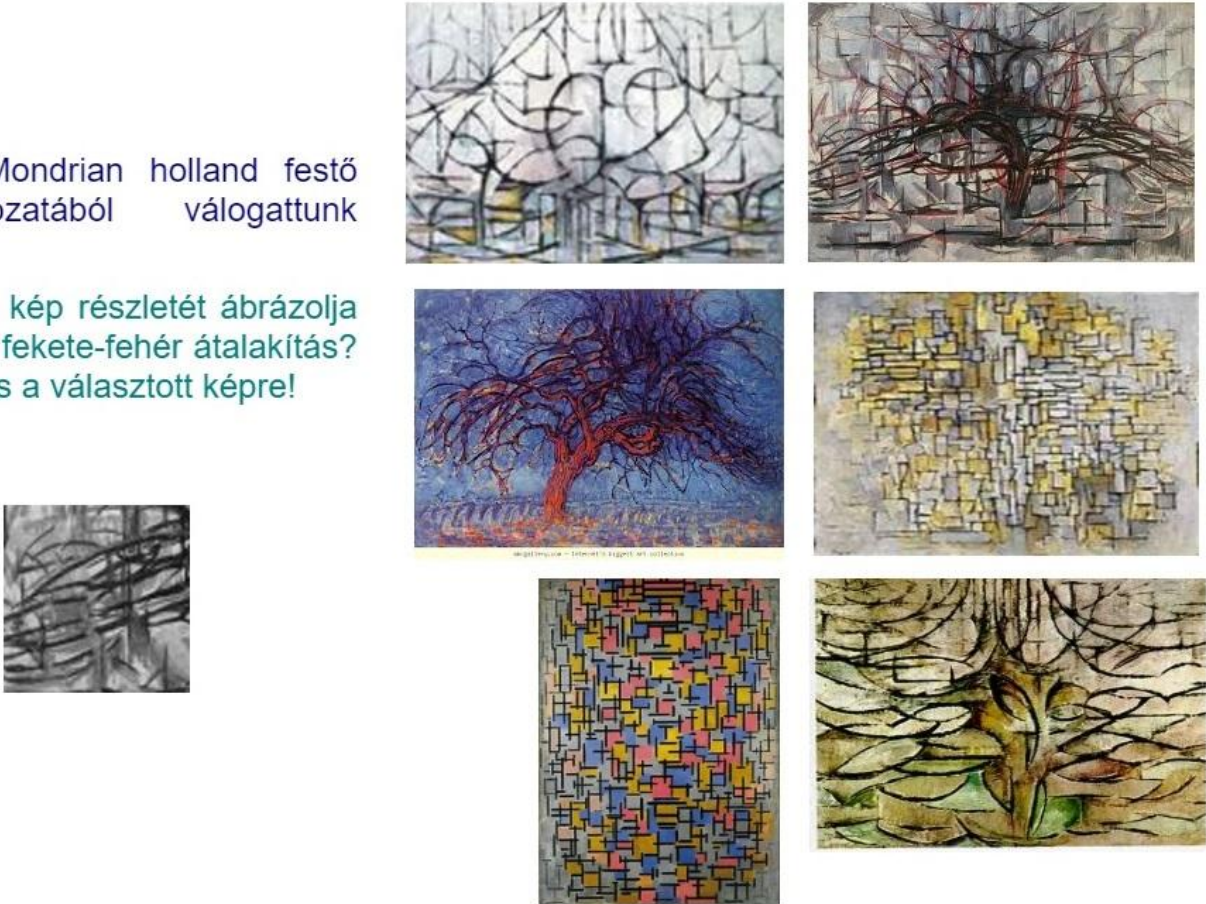

28. feladat Mondrian_kepkivagas_56

\section{6. feladat}

\section{$\square x$}

A köztéri szobrokat télen betakarják, mert védik az időjárás viszontagságaitól.
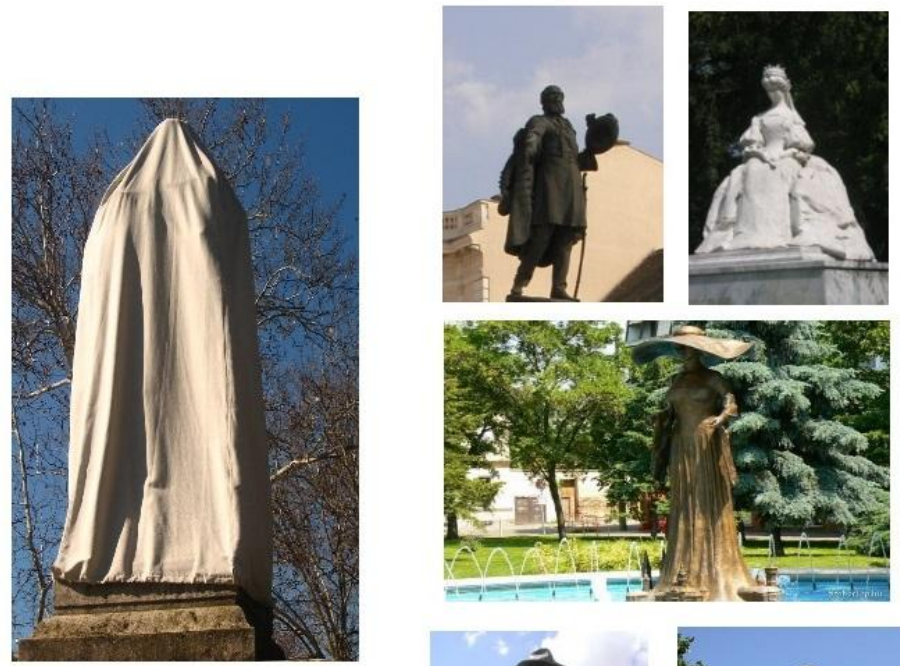

A csomagolás egy szegedi köztéri szobrot takar. Vajon melyik szobor rejtözik a lepel alatt? Kattints a kiválasztott szoborra!
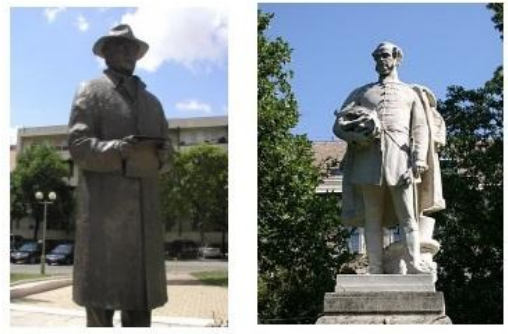


\section{7. feladat}

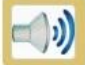

Melyik képből vágtuk ki az alábbi részletet?

Kattints a kiválasztott képre!
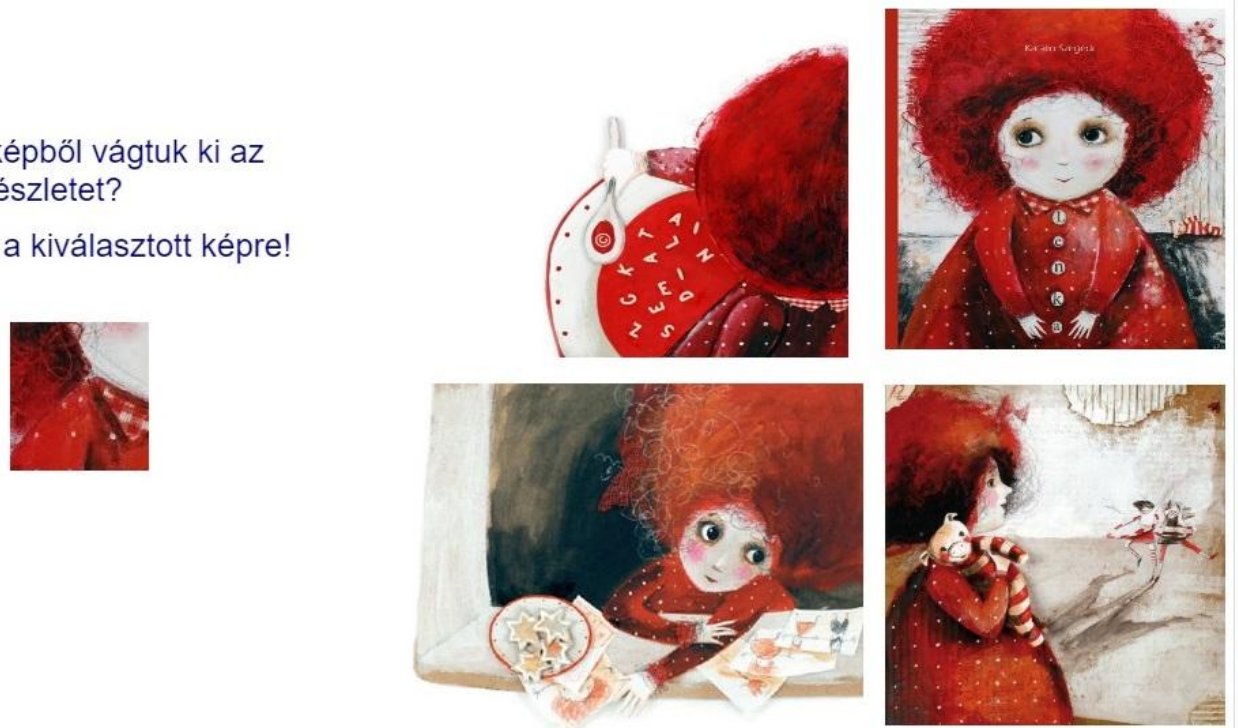

30. feladat Lenka_kepkivagas_5

\section{(D))}

\section{8. feladat}

A rajzok egyiptomi isteneket ábrázolnak, közülük négynek a leírását is elolvashatod.

Párosítsd a képeket a leírásokkal! A leírás előtti négyzetbe írd a hozzá tartozó kép számát!

* Minden leíráshoz egy rajz tartozik és az egyik rajznak nincs párja.
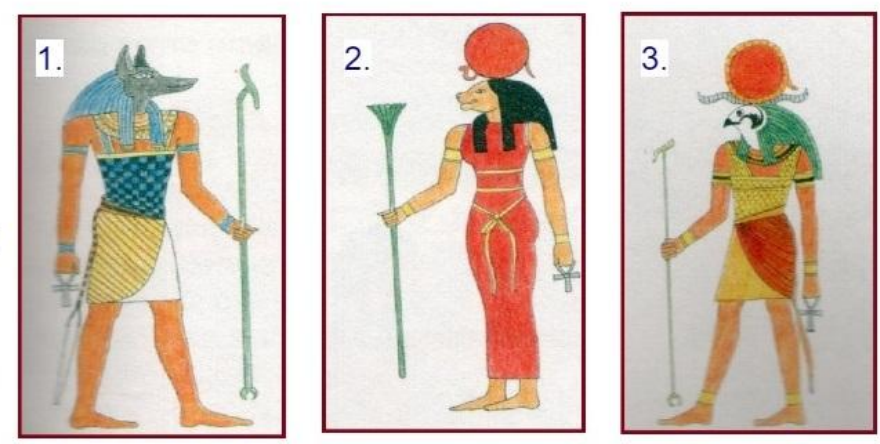

\section{(2))}

- Ré: Sólyomfejjel, szárnyas napkoronggal. Napisten.

- Ízisz: Gyakran ábrázolják szárnyakkal. Oltalmazó és varázsló istennő.

- Szahmet: Nőstény oroszlán képében vagy oroszlánfejú nőalakként ábrázolják. A bosszú és a háború istennője.

- Anubisz: Sakálként vagy embertesten sakálként ábrázolják. A balzsamozók istene.
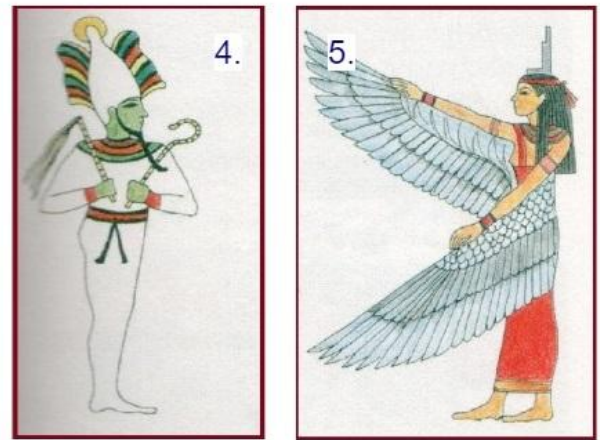

- Vissza

\section{1. feladat Egyiptomiistenek2_5}


11. feladat

D) Válaszd ki a képek közül azt a hármat, melyek együtt a "ketchup" szót jelentik. A kiválasztott képek betűjelére kattintva add meg válaszodat!

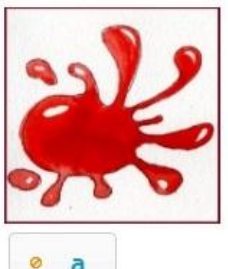

a

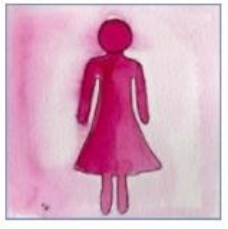

d

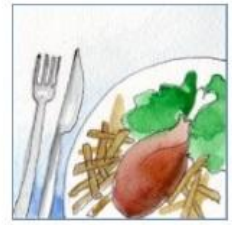

- b

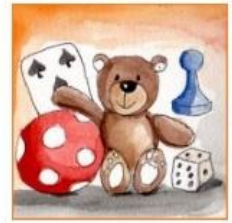

e
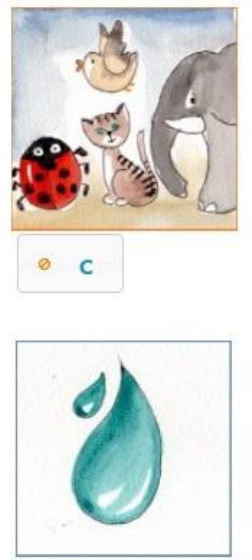

- $f$

32. feladat Piktogram_ketchup_5

\section{4. feladat}

Csoportosítsd a mủalkotásokat "Mozgalmas" és "Nem mozgalmas" halmazokba! A képekre húzd rá a "Mozgalmas" vagy a "Nem mozgalmas" kifejezést választásod szerint! Mozgalmas Nem mozgalmas
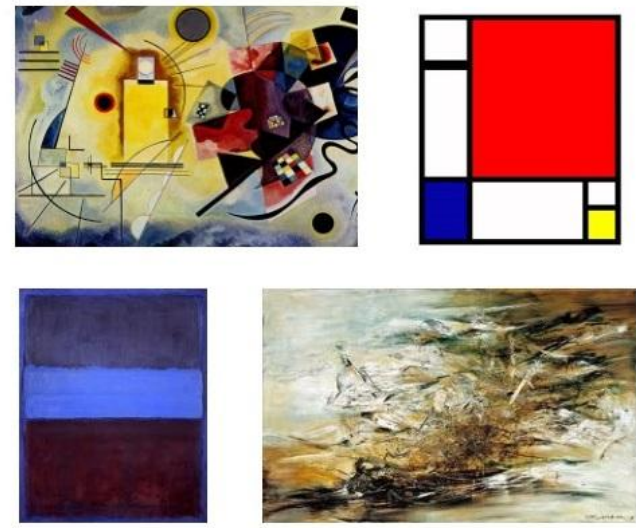

+ Vissza
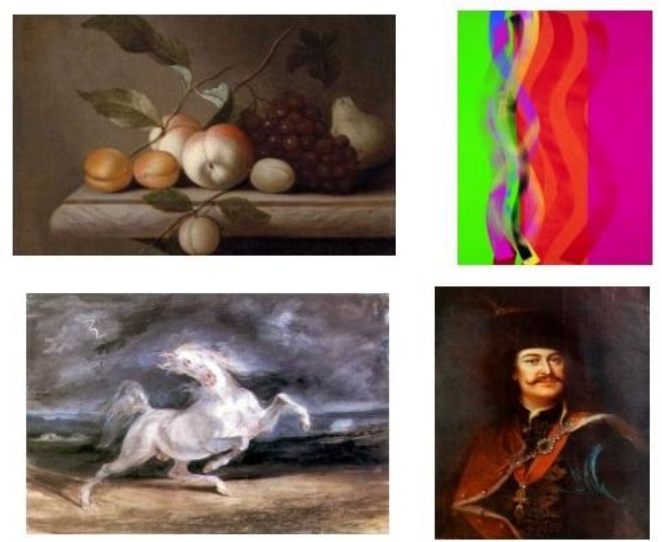

Elöre $\rightarrow$

33. feladat Mozgalmas_45 


\section{5. feladat}

- A képek Georgia O'Keeffe amerikai festômúvésznőt mutatják be életének két különböző időszakában .
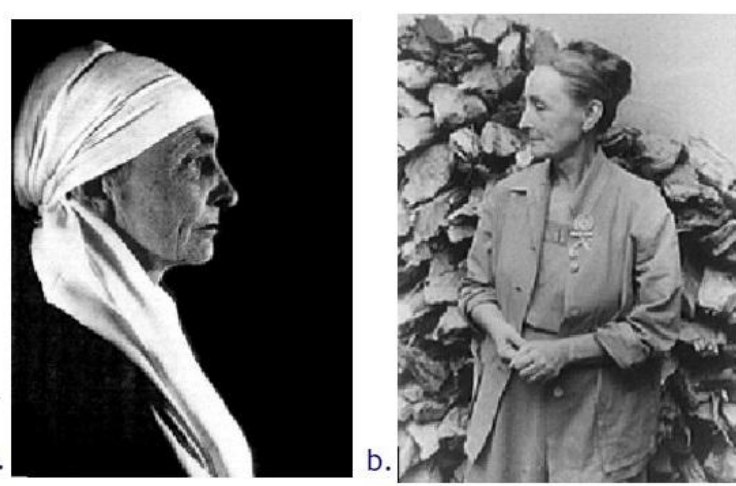

๑) Hasonlítsd össze a két képet! A megfelelő gomb megnyomásával válaszolj a kérdésekre!

a) A háttér részletgazdag

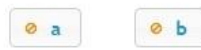

b) A figura elválik a háttértől

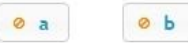

c) A fotó a szürkék különböző árnyalataira épül

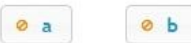

\section{4. feladat Okeffee_56}

\section{7. feladat}

Párosítsd az ábrákat a felsorolt szavakkal!

A választott szó számát írd a kép melletti négyzetbe!

Y Minden szóhoz egy kép tartozik, és egy szónak nincs párja.
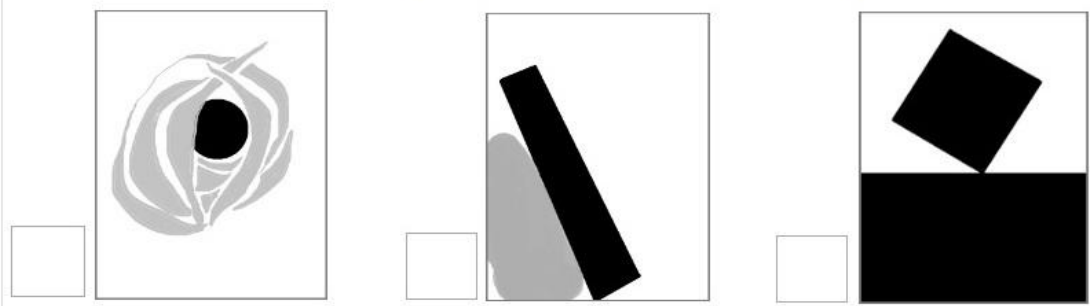

1. Keménység

2. Ringatás

3. Összenyomás
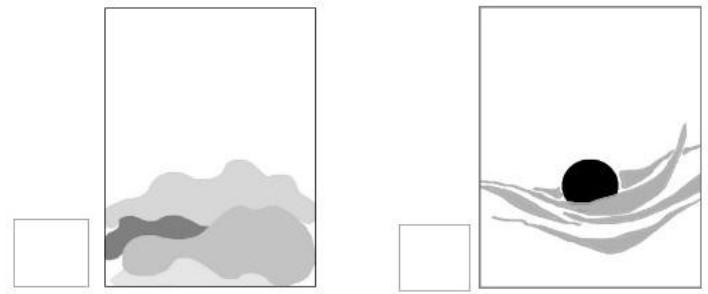

4. Lágyság

5. Emelkedés

6. Ölelés 
- A kép Bécs metrótérképét ábrázolja. A térkép alapján Bécsben hat metróvonal van, amelyet hat különböző színnel jelölnek.

Figyeld meg jól a térképet, és döntsd el, hogy az alábbi állítások közül melyik igaz, melyik hamis!

Az igaz állitások után "I", a hamis állitások után "H" betūt írj!

\section{D(1))}

- A piros vonal áthalad a folyón.

- A zöld vonal közvetlenül keresztezi az összes többi vonalat.

- A piros vonalról közvetlenül átszállhatok a barna vonalra.

- Három különböző metróvonal szeli át a folyót a térképen.
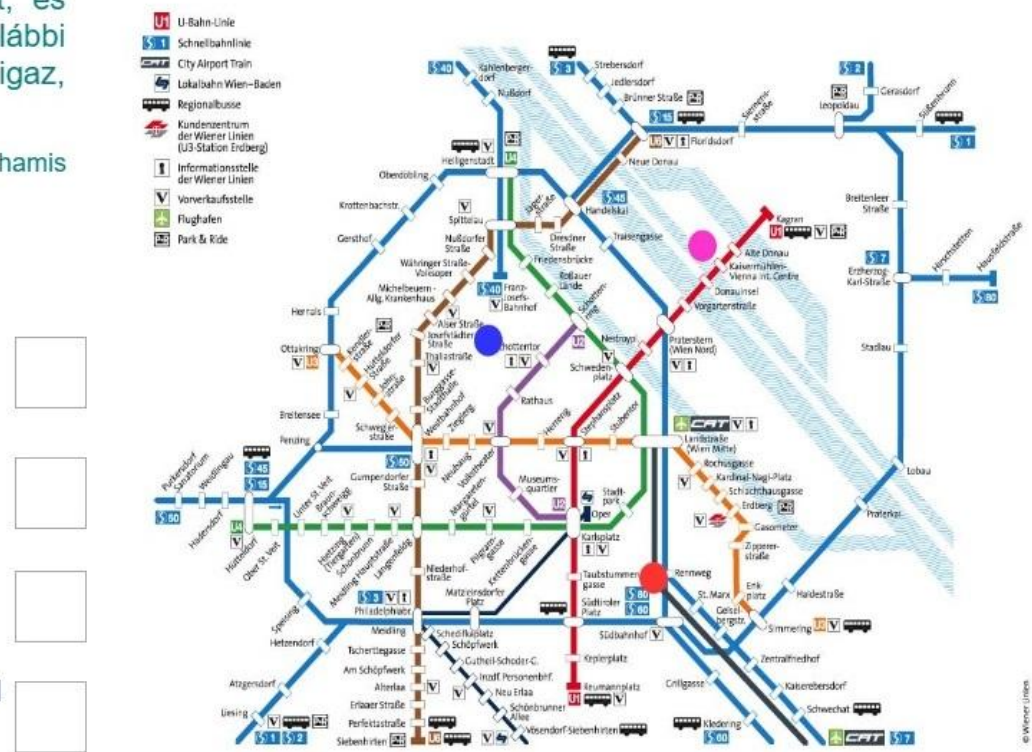

+ Vissza

36. feladat Metro_6

\section{1. feladat}

- Keith Haring, amerikai képzőmüvész egy sajátságos jelrendszert dolgozott ki gondolatai, érzései kifejezésére. Ezek a jelek képesek akár több szót, mondatot is ábrázolni. Ezekböl láthattok itt hatot.

ग) Nézd meg figyelmesen Haring képeit. Írd a kép számát az alábbi megállapítások közül a leginkább megfelelöhöz.

- Ezen a képen azonos gondolkodású embereket látok. Kiegészítik egymást, a gondolkodásviláguk megegyezik. Két test egy lélek.

- Itt egy ember botladozik. Elvesztette az egyensúlyát, a talajt a lába alól. Ingoványos területen jár. De az is lehet, hogy egy vízen járó alak, aki annyira bízik saját magában, hogy még erre is képes.
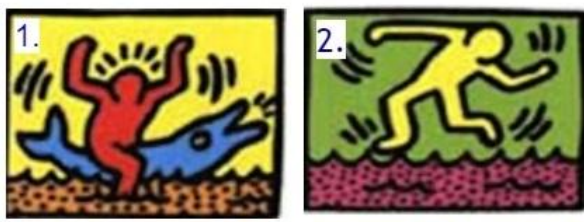

- Ez a két ember összenőtt. Amíg az egyik biztos lábakon áll, addig a másik nem tudja érvényesíteni a saját akaratát. Miközben meggátolja a saját lábán állót abban, hogy bármit is tegyen, mindketten tehetetlenné válnak.
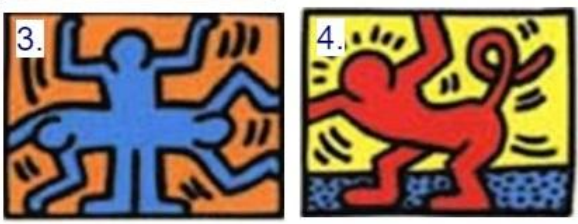

- Vissza
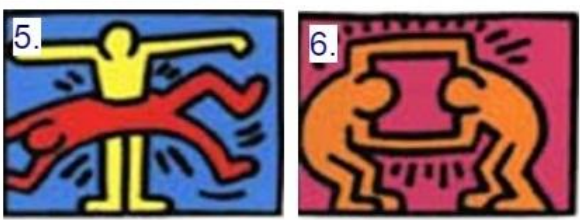

37. feladat Haring1_6 


\section{4. feladat}

\section{5) (1))}

- Andy Warhol, amerikai múvész több színes nyomatot készített ugyanazokról a virágokról. A nyomatok négy szürke árnyalatos variációját látod.

Kattints arra a szürkeárnyalatos képre, amelyik a színes kép tónusokban megfelelő párja!
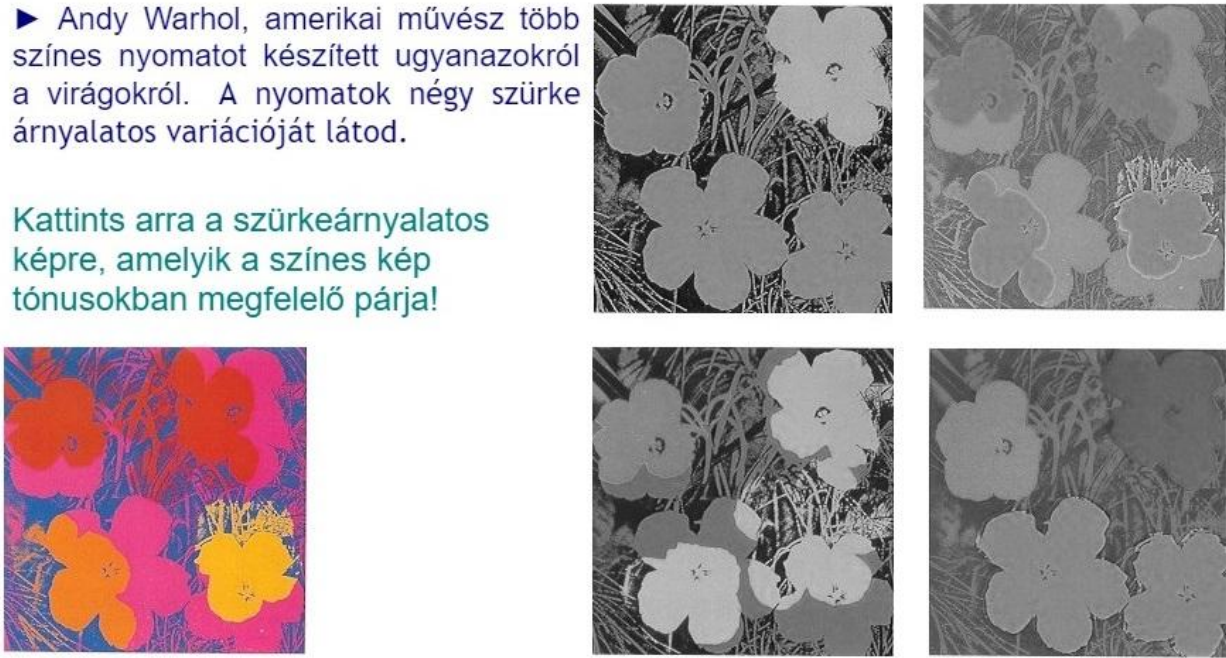

7. feladat

\section{(1))}

Kattints arra a képre, amelyikröl az alábbi leírás szól!

Ez a ló egy igazi, ereje teljében lévő, izmos paripa. Szöre fényes, ápolt, csillog. Sörényének, farkának libbenése mutatja eröteljes, de nem heves mozdulatát. A háttér egyszínủ, kicsi árnyék jelzi csak a ló patájánál, hogy nem lebeg, hanem a földön van.
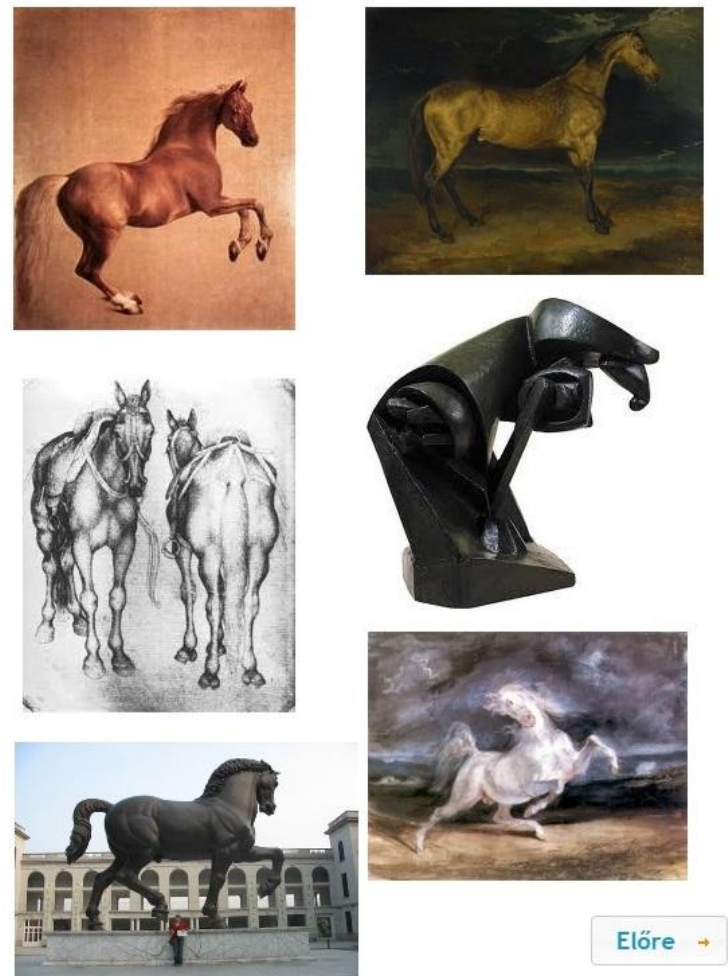

39. feladat Lovak_6 


\section{9. feladat}

๑)) A képek különböző korokból származó műalkotások.

Mi a közös a festményekben?

Válassz egyet a felsorolt lehetőségek közül!

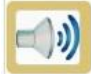

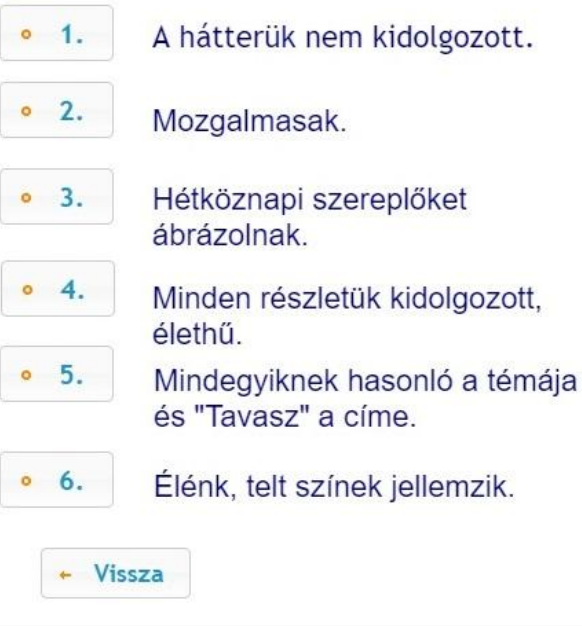
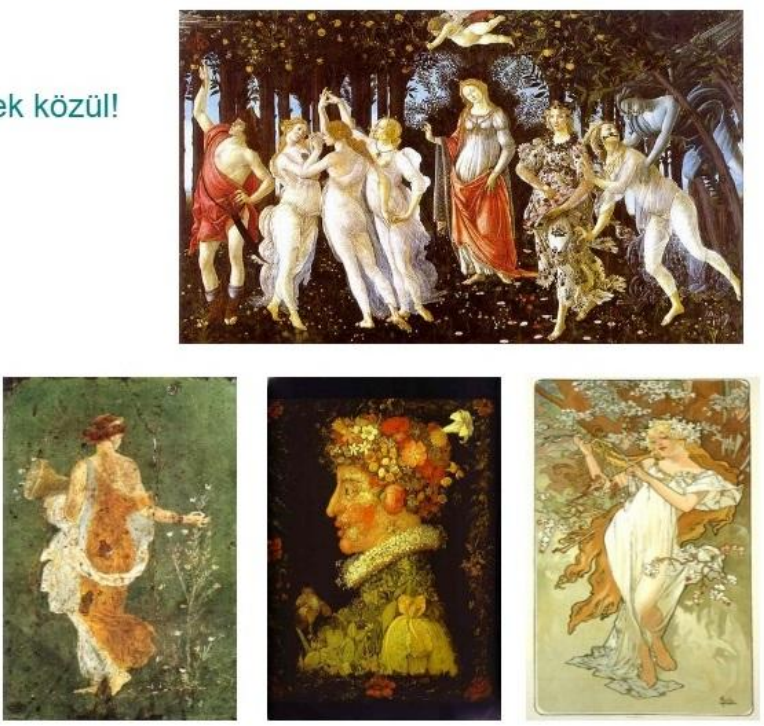

40. feladat Tavasz_6

\section{1. feladat}

(j)) A fotókon látható gimnazisták mủalkotások szereplőinek mozdulatait utánozták.

Keresd meg, melyik kép, melyiknek a párja!

: Vigyázz, van a képek között tükörkép is! Egy müalkotásnak nincs párja.

Írd a képeken található négyzetbe a kiválasztott kép számát!
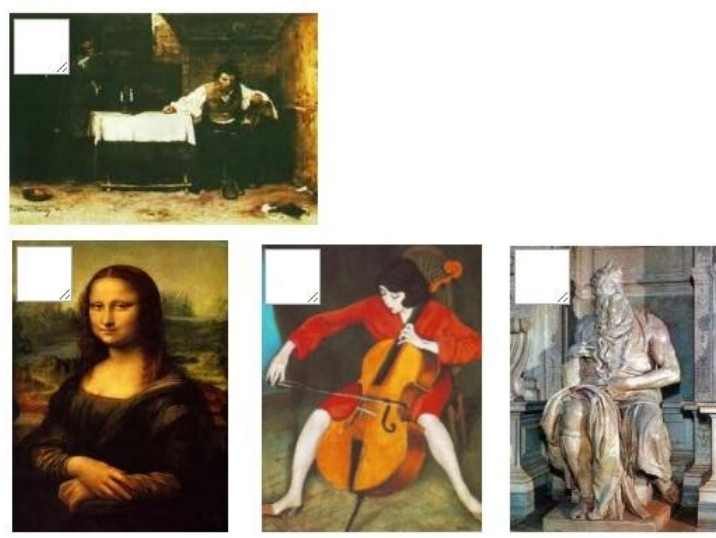

+ Vissza
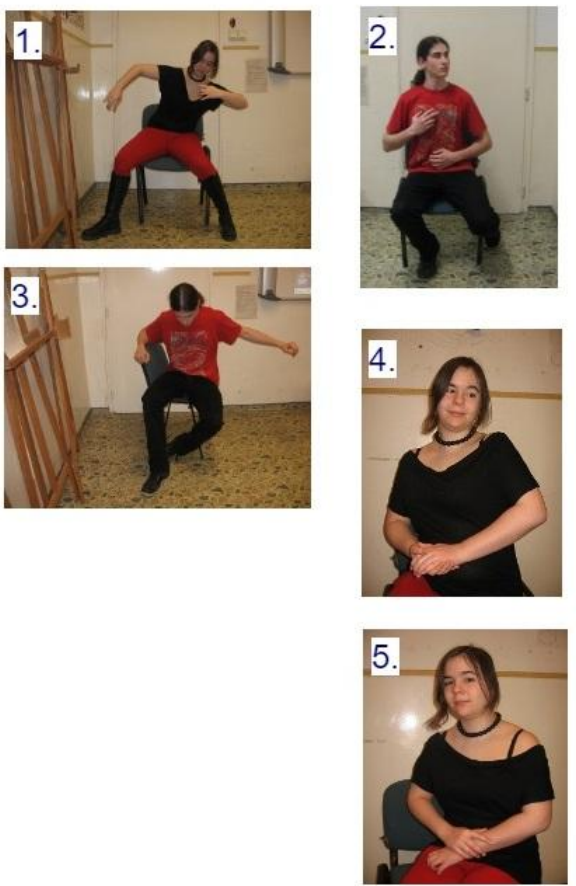

Elöre $\rightarrow$

\section{1. feladat Mozdulatok3_6}


( )) Pista bácsi leírta és lerajzolta a gyerekeknek a bemelegítő gyakorlatsort. Melyik leíráshoz melyik rajz tartozik? Írd a leírás előtti négyzetbe a megfelelő rajz számát!

๑) Minden rajzhoz csak egy leírás tartozik és egynek nincs párja.

- Ugrás guggoló támaszba és térdrúgózás háromszor, majd térdnyújtás alapállásba.

- Szökdelés helyben háromszor, majd ugrás terpeszállásba karlendítéssel oldalsó középtartásba.

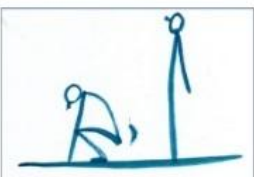

1.

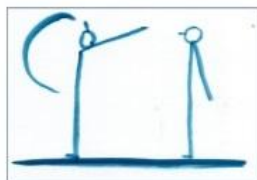

3.

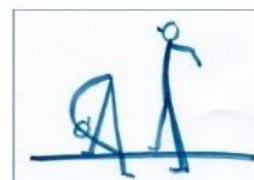

2.

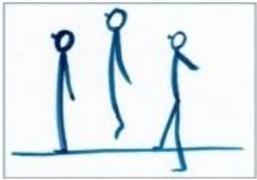

4.

- Karkeresztezés a test elött. Karlendítés vissza oldalsó középtartásba. Karhúzás hátra kétszer.

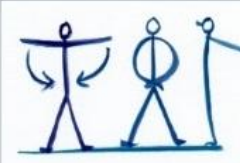

- Vissza

5.

Elöre -

\section{5. feladat}

1)) A képek az ókori görög mitológia jeleneteit és szereplőit ábrázolják. Párosítsd a képeken szereplő lényeket a leírásokkal! A választott kép betűjelét írd a meghatározások előtti négyzetbe!

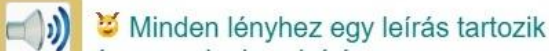
és egynek nincs leírása.

- Gigászok: Gaia, a Földistennő kígyólábú fiai.

- Daphné: Nimfa, Apollón szerelme elöl menekülve babérfává változott.

- Atlasz: Uranosz és Gaia fia, titán, az égboltot tartja a vállán.

- Griff: Kutyafejü, oroszlántestü, csőrös, szárnyas szörny.

- Szatír: Dionüszosz félig ember, félig kecske alakú kísérője.
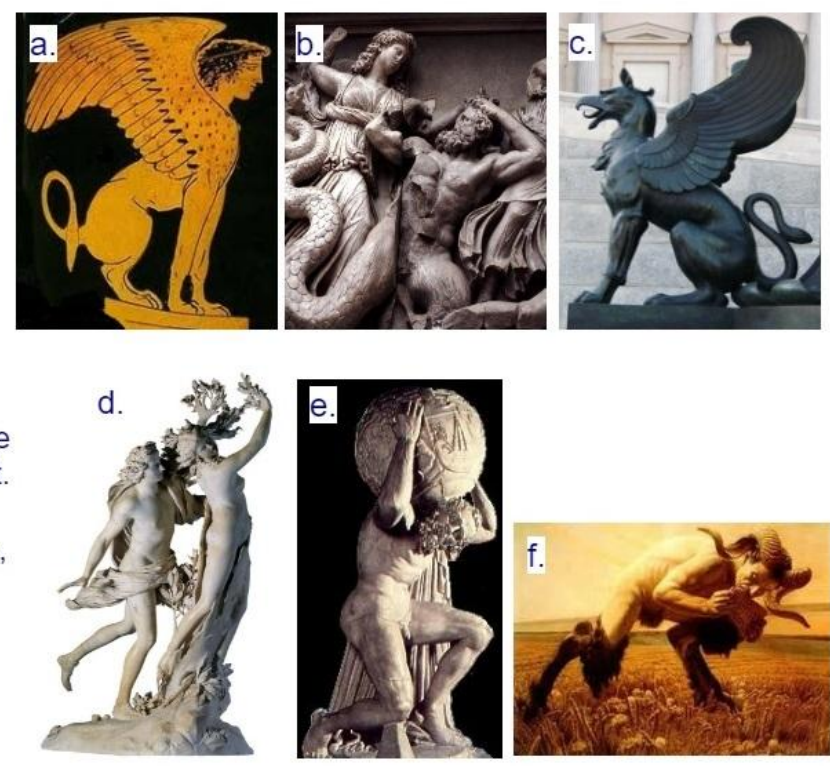

43. feladat Gorogmitologiailenyek_6 


\section{1. feladat}

๑) A) A turisták Pásztóról indultak Gyöngyösre, az útvonalukat narancs, zöld és rózsaszín vonal jelzi.

A térkép alapján döntsd el, igazak vagy hamisak az állítások. Ha igaz, írj "i" betüt, ha (1)) hamis, írj "h" betüt az állitás utáni négyzetbe!

- A narancs útvonal halad át a legmagasabb hegyeken.

- A narancs és a zöld útvonalon haladók találkoztak egymással útközben.

- A zöld út kikerüli a legmagasabb csúcsokat.

- A rózsaszín nem érint településeket.

- A rózsaszínen

haladók átkeltek a Zagyva folyón.

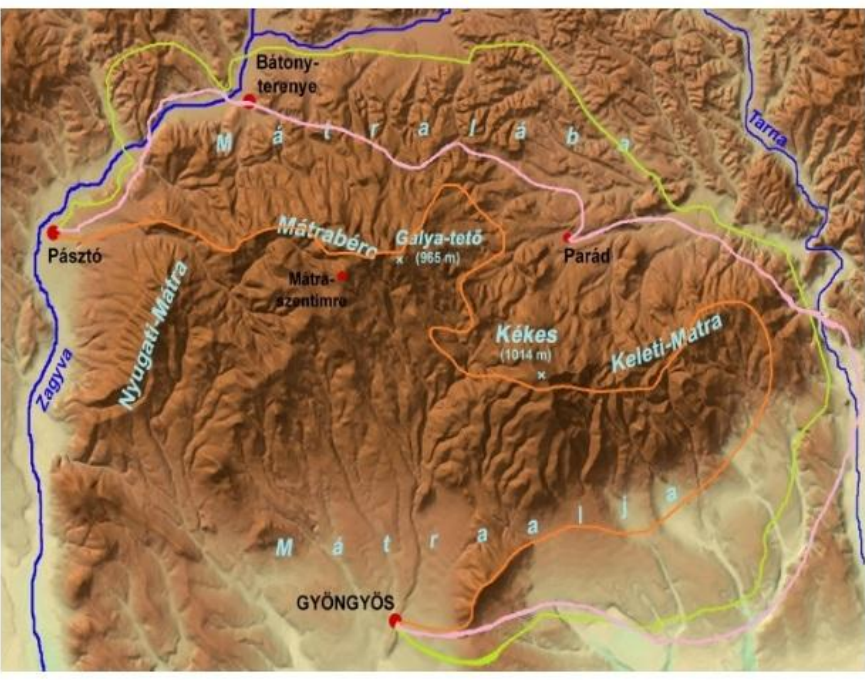

+ Vissza

Elöre $\rightarrow$

44. feladat Topografia_6

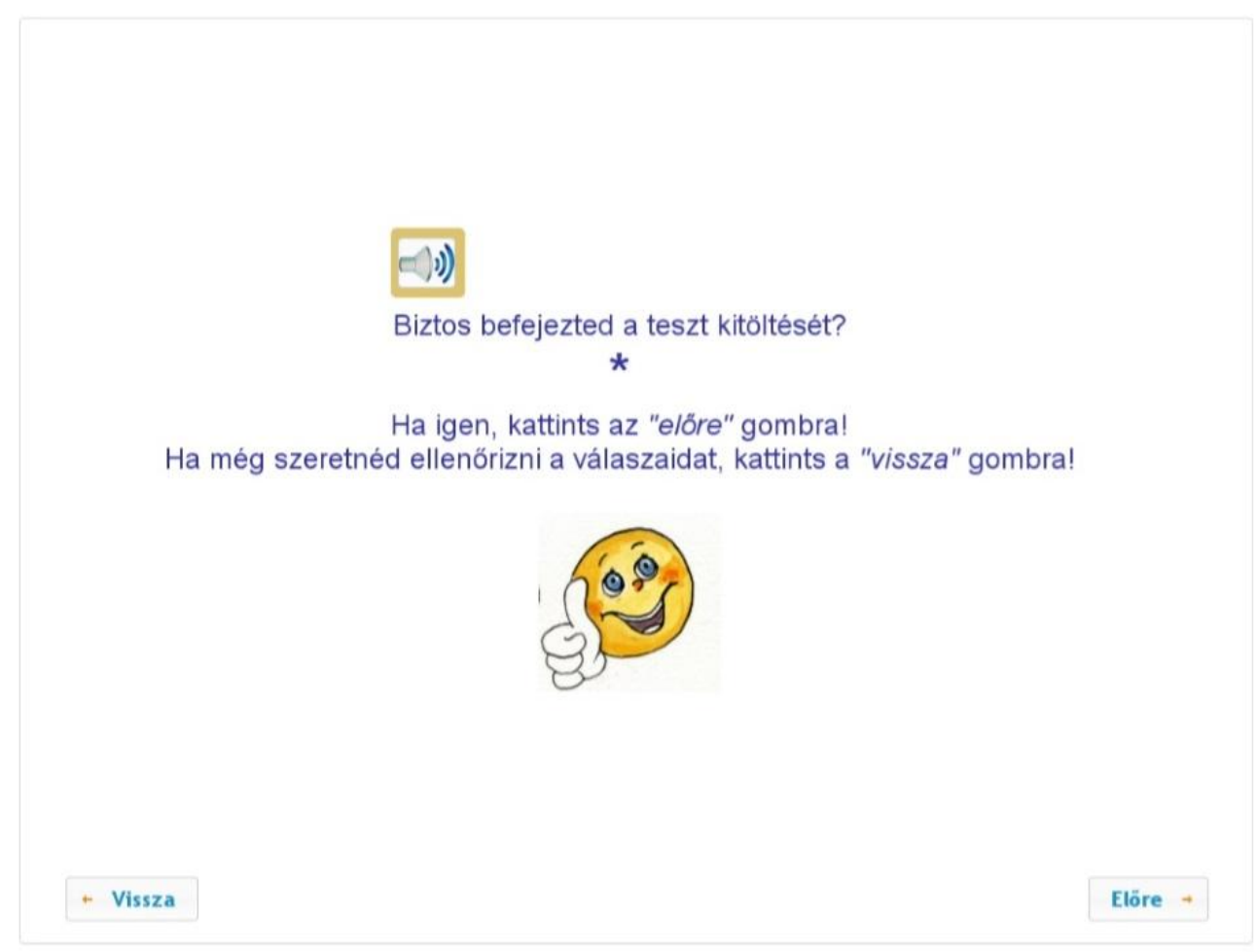




\section{2. sz. melléklet}

Értékelő feladatok a vizuális képességcsoport részképességeihez, szintenként. A feladatok elnevezése a tartalmi elemekre utal, illetve a feladat elnevezésében megjelenő számok jelentik meg sorban az itemszámokat (v1, v2, stb.), illetve az évfolyamot, melyek megcsinálták az adott itemet. Vannak azonos elnevezésü feladatok, melyek mögött közvetlenül megjelenő szám jelzi, hogy az adott feladat hányadik variáció (például „szavakesabrak2”). A vastagon szedett itemek a mindhárom évfolyam tesztjében megjelenő horgonyitemek.

\begin{tabular}{|c|c|c|c|c|}
\hline $\begin{array}{l}\text { Részképességek } \\
\text { Képességszintek }\end{array}$ & Komponálás síkban & Absztrakció & Szzimbolizáció & Modalitásváltás \\
\hline $\begin{array}{l}\text { Vizuális } \\
\text { felismerés }\end{array}$ & $\begin{array}{l}\text { hidegszinekegerkes_4 } \\
\text { mozdulatok3_v1_6 } \\
\text { mozdulatok3_v2_6 } \\
\text { mozdulatok3_v3_6 } \\
\text { mozdulatok3_v4_6 } \\
\text { leplekoroszlan_4 } \\
\text { leplekalatt2_4 } \\
\text { leplekalatt2_56 } \\
\text { mozdulatok_w1_4 } \\
\text { mozdulatok_w2_4 } \\
\text { mozdulatok_w3_4 } \\
\text { mozdulatok_w4_4 }\end{array}$ & $\begin{array}{l}\text { terkep_v5_456 } \\
\text { terkep_v4_456 } \\
\text { terkep_v3_456 } \\
\text { terkep_v2_456 } \\
\text { terkep_v6_456 } \\
\text { Szavakesabrak4_v } \\
\text { 1_4 } \\
\text { szavakesabrak4_v } \\
\text { 2_4 } \\
\text { Szavakesabrak4_v } \\
\text { 3_4 } \\
\text { Szavakesabrak4_v } \\
\text { 4_4 } \\
\text { szavakesabrak4_v } \\
\text { 5_4 }\end{array}$ & $\begin{array}{l}\text { piktogram_v1_45 } \\
\text { piktogram_v2_45 } \\
\text { piktogram_v4_45 } \\
\text { piktogram_v5_45 } \\
\text { piktogram_v6_45 } \\
\text { piktogram_v7_45 } \\
\text { piktogram_v8_45 }\end{array}$ & $\begin{array}{c}\text { gorogmitologiai } \\
\text { lenyek_v1_6 } \\
\text { gorogmitologiai } \\
\text { lenyek_v2_6 } \\
\text { gorogmitologiai } \\
\text { lenyek_v3_6 } \\
\text { gorogmitologiai } \\
\text { lenyek_v4_6 } \\
\text { gorogmitologiai } \\
\text { lenyek_v5_6 } \\
\text { egyiptomiistene } \\
\text { k2_v1_5 } \\
\text { egyiptomiistene } \\
\text { k2_v2_5 } \\
\text { egyiptomiistene } \\
\text { k2_v3_5 } \\
\text { egyiptomiistene } \\
\text { k2_v4_5 }\end{array}$ \\
\hline $\begin{array}{l}\text { Vizuális } \\
\text { értelmezés }\end{array}$ & $\begin{array}{l}\text { szinarnyalatok_gyongysz } \\
\text { inezes_4 } \\
\text { szirnyalatok_gyongyszin } \\
\text { ezes_5 } \\
\text { haring_kepkivagas_4 } \\
\text { mondrian_kepkivagas_5 } \\
6 \\
\text { lenka_kepkivagas_5 } \\
\text { okeffee_v1_56 } \\
\text { okeffee_v2_56 } \\
\text { okeffee_v3_56 } \\
\text { mozgalmas_m1_4 } \\
\text { mozgalmas_nm1_4 } \\
\text { mozgalmas_m1_5 } \\
\text { mozgalmas_nm1_5 } \\
\text { picasso_v1_56 } \\
\text { picasso_v2_56 } \\
\text { picasso_v3_56 } \\
\text { picasso_v4_56 } \\
\text { picasso_v5_56 } \\
\text { hokkontraszt_v1_meleg } \\
5 \\
\text { hofokkontraszt_v2_hideg } \\
5\end{array}$ & 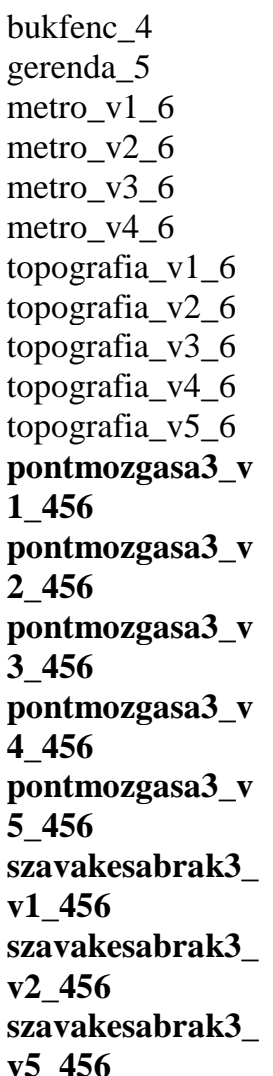 & $\begin{array}{l}\text { sarkany_4 } \\
\text { piktogramoktelapo_ } \\
4 \\
\text { piktogramfurulya } \\
\mathbf{4 5 6} \\
\text { piktogram_ketchup } \\
\text {-5 } \\
\text { csaladfa_4 } \\
\text { Gainsborough_4 }\end{array}$ & $\begin{array}{l}\text { varazslobenedek } \\
\text { _v1_4 } \\
\text { varazslobenedek } \\
\text { _v2_4 } \\
\text { varazslobenedek } \\
\text { _v3_4 } \\
\text { varazslobenedek } \\
\text { _v4_4 } \\
\text { tornagyakorlato } \\
\text { k2_v1_6 } \\
\text { tornagyakorlato } \\
\text { k2_v2_6 } \\
\text { tornagyakorlato } \\
\text { k2_v3_6 } \\
\text { tornagyakorlato } \\
\text { k2_v4_6 } \\
\text { zene1_w1_456 } \\
\text { zene1_w2_456 } \\
\text { zene1_w3_456 } \\
\text { zene1_w4_456 } \\
\text { zene2_w1_456 } \\
\text { zene2_w2_456 } \\
\text { zene2_w3_456 } \\
\text { zene2_w4_456 } \\
\text { palacsintasorren } \\
\text { d_5 }\end{array}$ \\
\hline
\end{tabular}




\begin{tabular}{|c|c|c|c|}
\hline & & $\begin{array}{l}\text { szavakesabrak3_ } \\
\text { v4_456 } \\
\text { szavakesabrak2_v } \\
\text { 2_56 } \\
\text { szavakesabrak2_v } \\
\text { 3_56 } \\
\text { szavakesabrak2_v } \\
\text { 4_56 } \\
\text { szavakesabrak2_v } \\
\text { 5_56 } \\
\text { szavakesabrak2_v } \\
\text { 6_56 }\end{array}$ & \\
\hline Vizuális elemzés & $\begin{array}{l}\text { szinelemzes_v1_56 } \\
\text { szinelemzes_v2_56 } \\
\text { szinelemzes_v3_56 } \\
\text { szinelemzes_v4_56 } \\
\text { szinkeveresharomszirmu } \\
\text { virag_4 } \\
\text { lovak_6 } \\
\text { warhol2_6 } \\
\text { batman2_56 }\end{array}$ & $\begin{array}{l}\text { pontmozgasa_45 } \\
6\end{array}$ & $\begin{array}{l}\text { tavasz_6 } \\
\text { haring1_v1_6 } \\
\text { haring1_v2_6 } \\
\text { haring1_v3_6 }\end{array}$ \\
\hline
\end{tabular}




\section{3. sz. melléklet}

a) feladat

SZTE / TÁMOP 3.1.9. / Diagnosztikus mérések fejlesztése / Rajz és vizuális kultúra / Feladatlap / 2010.

Az iskola bélyegzője:

\begin{tabular}{|l|l|l|l|}
\hline \multicolumn{2}{l|}{ Az iskola bélyegzője: } & Az iskola kódja: & \\
\cline { 3 - 4 } & A tanuló kódja: & \\
\hline A tanuló neve: & Fiú—Lány & Évfolyam: & \\
\hline
\end{tabular}

Feladatazonosító: 0614

\section{A feladat címe: Mesebeli király}

\section{Hallgasd meg a mesét, majd oldd meg a feladatokat!}

Hol volt, hol nem volt, volt egyszer egy király és egy királyné, akiknek sorban született három fiuk. Telt-múlt az idö, a gyerekek felnöttek és feleséget választottak maguknak. A legidösebb királyfi a Virágot Nevetö Királykisasszonyt, a középsö királyfi Világszép Nádszálkisasszonyt, míg a legkisebb királyfi az Aranyhajú Királykisasszonyt vette feleségül. A legidösebb királyfinak hamarosan született egy fia; a középsö királyfi családja szintén egy fiúgyermekkel gyarapodott, a legkisebb királyfiéknál pedig két ikerkislány született. Itt megállitjuk a mese folyását...

Ábrázold egyetlen rajzban az egész felséges királyi pereputtyot úgy, hogy mutasd meg a családtagok közötti szülö-gyermek összefüggést is!

A rajzba legfeljebb számokat és a szereplők elnevezését írhatod be, egyéb szöveget nem. Törekedj arra, hogy az ábrád mutassa meg a személyek közötti kapcsolatokat.

6 színü filctoll-készletet használhatsz; fontold meg, hogy a rajz egyes részeinél milyen színnel ábrázolsz.

\begin{tabular}{|l|l|l|l|l|l|l|l|l|l|l|}
\hline $\mathbf{1 1 . 1}$ & $\mathbf{1 1 . 2}$ & $\mathbf{1 1 . 3}$ & $\mathbf{8 . 1}$ & $\mathbf{8 . 2}$ & & & & & \\
\hline & & & & & & & & & & \\
\hline
\end{tabular}


b) feladat

SZTE / TÁMOP 3.1.9. / Diagnosztikus mérések fejlesztése / Rajz és vizuális kultúra / Feladatlap / 2010.

\begin{tabular}{|l|l|l|l|}
\hline Az iskola bélyegzője: & $\begin{array}{l}\text { Az iskola } \\
\text { kódja: }\end{array}$ & \\
\cline { 3 - 4 } & & A tanuló kódja: & \\
\hline A tanuló neve: & Fiú—Lány & Évfolyam: & \\
\hline
\end{tabular}

Feladatazonosító: 0916

\section{A feladat címe: O’Keeffe}

Alfred Stieglitz, híres fotóművész több fotót is készített Georgia O’Keeffe (1887-1986) amerikai festőművésznőről és alkotásairól. Többek között ezeket a fotókat tartalmazza a Susan Danly: Georgia O'Keeffe és a Kamera címü könyve. A könyv borítólapját láthatod az 1. számú képen.

Alfred Stieglitz képei a művésznőt életének különböző időszakában mutatják be.
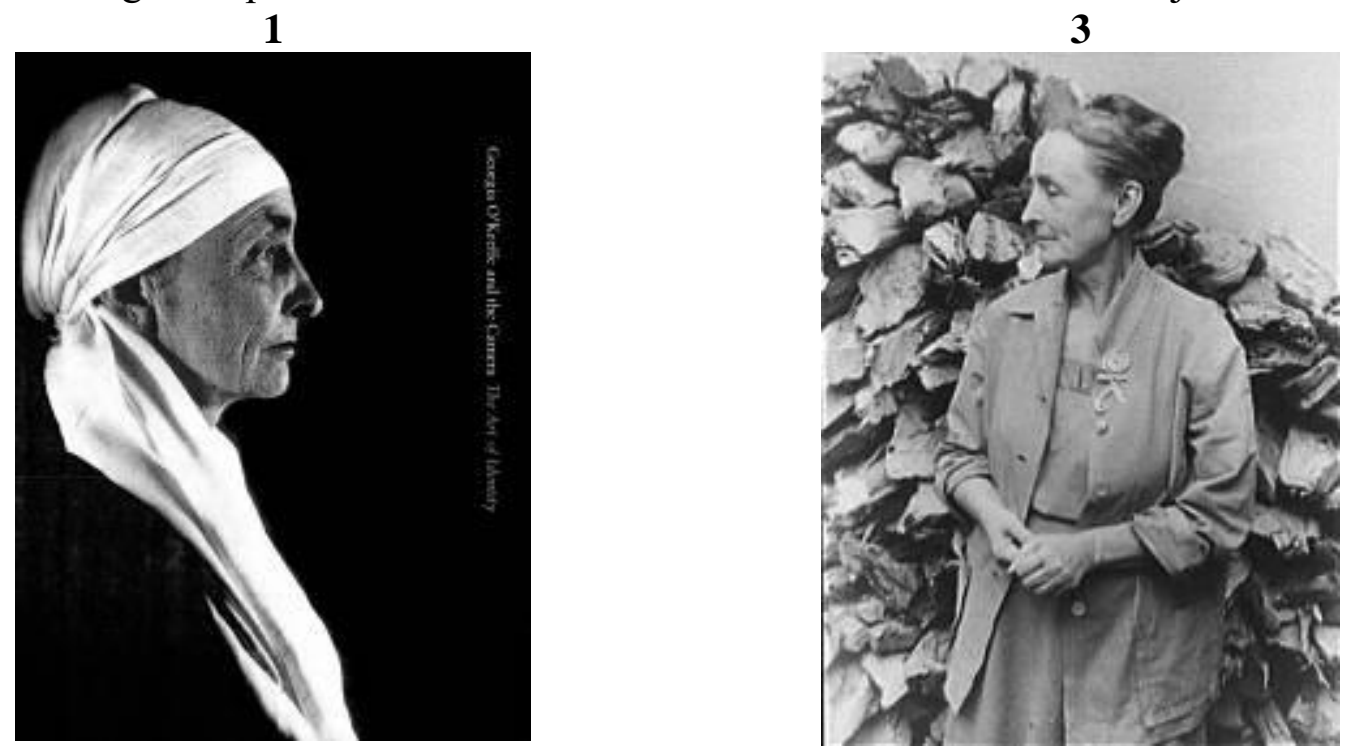

1) Hasonlítsd össze az 1-es és a 3-as képet! Írj 1-est vagy 3-ast az arra a képre jellemző megállapítás után!

a) A háttér részletgazdag:

b) A figura elválik a háttértöl:

c) A figurának csak a feje válik el a háttértől a test többi része kivehetetlen:

d) A fotó a szürkék különböző árnyalataira épül:

e) Egyedül az arc szürke, a kép többi része a fekete és a fehér ellentétére épül:

f) Egyensúlyos kompozíció:

g) A kép a világos és a sötét éles ellentétére épül:

h) A sál és az arc elhelyezése dinamikussá teszik a kompozíciót:.

i) A figura a kép közepén helyezkedik el:

j) A figura természetes megvilágításban van:

k) A figura inkább a kép baloldalán helyezkedik el:

1) A háttér egyszínű fekete:

m) Valamennyi formára jellemző a testesség: 
n) A képelemek elrendezése egyensúlyt teremt:

o) A leginkább kifejező, hatásos:

2) Mitől lesz az 1-es képen látható arc és a sál anyagszerü? Karikázd be a megfelelő állítás betüjelét!

A) A különböző helyzetü megvilágítástól

B) A színektől

C) Az elhelyezéstől

3) Karikázd be a felsorolásból azokat a megállapításokat, amelyek szerinted leginkább magyarázzák a könyv címének a kép jobb oldalán, függőlegesen való elhelyezését! Több helyes válasz is lehetséges!

A) Olyan a szöveg mintha O'Keeffe arca elött lenne valami, amibe belenéz.

B) Ott volt hely.

C) Hogy az olvasó elfordítsa a fejét, ha el akarja olvasni.

D) Nem a könyv címe a fontos, hanem a müvésznő portréja.

E) A fotó úgyis megmutatja mindenki számára, hogy kiről szól a könyv, nincs szükség a címre.

\begin{tabular}{|l|l|l|l|l|l|l|l|l|l|l|l|l|l|l|l|l|l|l|l|}
\hline & & & & & & & & & A FELADAT ÉRTÉ KELÉSE. & \\
$\mathbf{a}$ & $\mathbf{b}$ & $\mathbf{c}$ & $\mathbf{d}$ & $\mathbf{e}$ & $\mathbf{f}$ & $\mathbf{g}$ & $\mathbf{h}$ & $\mathbf{i}$ & $\mathbf{j}$ & $\mathbf{k}$ & $\mathbf{l}$ & $\mathbf{m}$ & $\mathbf{n}$ & $\mathbf{o}$ & & $\mathbf{a}$ & $\mathbf{b}$ & $\mathbf{c}$ & \\
\hline & & & & & & & & & & & & & & & & & & & \\
\hline
\end{tabular}




\section{4. sz. melléklet}

A vizuális kommunikációs képesség online mérése Kérdöív

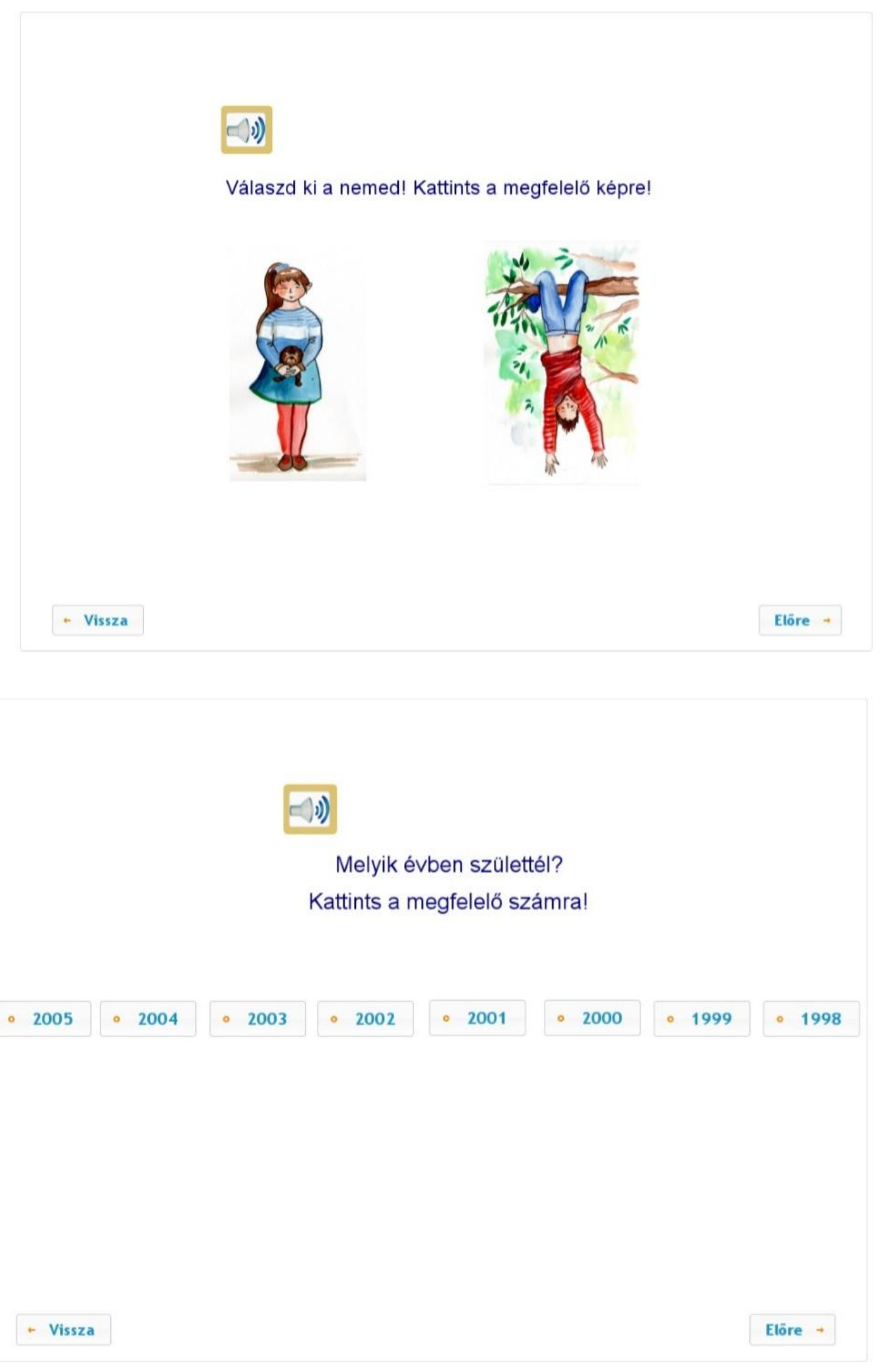


๑) Mit szoktál olvasni? Válaszd ki a három legjellemzöbbet!

\begin{tabular}{|c|c|}
\hline - & regényeket \\
\hline - & képes magazinok \\
\hline
\end{tabular}

tankönyvet

képregényeket

barátaim/ismeröseim üzeneteit

számitógépes játékok utasításait/leirásait

reklámújságot/szórólapokat

ismeretterjesztö írásokat

rejtvényújságot

- sztárpletykákat

E(0)) Sehol nem tudok internetet használni.

CDiv) Volna lehetöségem internethasználatra, de nem szoktam internetezni.

독) Van internet-hozzáférésem, és szoktam használni. 
- hetente 1.2 ór O hetente 3.6 órát (1))

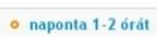

(5)) (a)

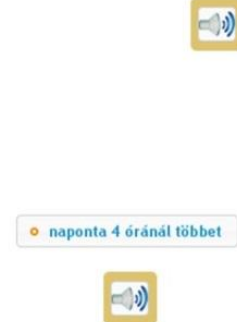

(a)

Vissza

\section{(1))}

Milyen gyakran számitógépezel? Kattints a megfelelö válaszra!

- soha

- hetente 1-2 órát

- hetente 3-6 órát

- naponta 1-2 órát

- naponta 3-4 órát

- naponta 4 óránál többet 


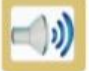

Lássuk a feladatokat!

23 feladatod lesz, jól oszd be az idődet!

Ha valamelyik feladatot nem tudod, kitöltés nélkül tovább haladhatsz, majd vissza is lépkedhetsz, amíg el nem éred az utolsó oldalt.

Elkészülni, vigyázz, kész, tüz, rajt!

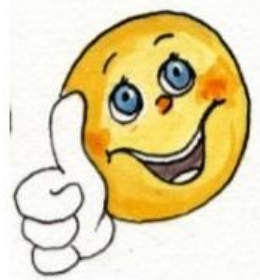

Megjegyzés A teszteket bevezetö felület

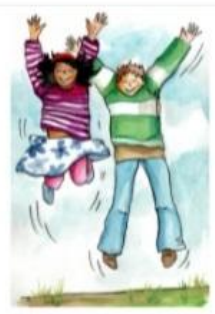

A teszt végére értél!

Most egy rövid kérdéssor következik.

A kérdések megválaszolása után megmutatjuk a teszten elért eredményedet!

Kattints az Elöre gombra! 


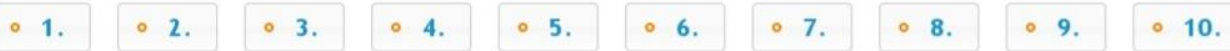

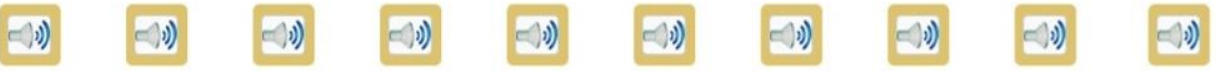

Hányas voltál az elmúlt félév végén a következö tárgyakból?

\begin{tabular}{|c|c|c|c|c|c|c|c|}
\hline Tantárgy & Hang & Érdemjegy & Érdemjegy & Érdemjegy & Érdemjegy & Érdemjegy & \begin{tabular}{|c|} 
Nem \\
tanultam \\
ilyen \\
targyat
\end{tabular} \\
\hline Magyar nyelv és irodalom & $B(0)$ & $\circ 1$ & $\circ 2$ & $\circ 3$ & $\circ 4$ & $\circ 5$ & $\circ$ \\
\hline Idegen nyelv & $\theta(0)$ & $\circ 1$ & $\circ 2$ & $\circ 3$ & $\circ 4$ & $\circ 5$ & $\circ$ \\
\hline Matematika & (c) $(0)$ & $\circ 1$ & $\circ 2$ & $\circ 3$ & $\circ 4$ & $\circ 5$ & $\circ$ \\
\hline Történelem & $\theta(0)$ & $\circ 1$ & $\circ 2$ & $\circ 3$ & $\circ 4$ & $\circ 5$ & 。 \\
\hline Környezetismeret/természetismeret & 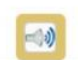 & - 1 & $\circ 2$ & $\circ 3$ & $\circ 4$ & $\circ 5$ & 。 \\
\hline
\end{tabular}




\begin{tabular}{|c|c|c|c|c|c|c|c|}
\hline Tantárgy & Hang & Érdemjegy & Érdemjegy & Érdemjegy & Érdemjegy & Érdemjegy & $\begin{array}{c}\text { Nem } \\
\text { tanultam } \\
\text { ilyen } \\
\text { targyat }\end{array}$ \\
\hline Rajz/vizuális kultúra & E(D) & $\circ 1$ & $\circ 2$ & $\circ 3$ & $\circ 4$ & $\circ 5$ & $\circ$ \\
\hline Testnevelés & $E(D)$ & $\circ 1$ & - 2 & $\circ 3$ & - 4 & $\circ 5$ & $\circ$ \\
\hline Informatika/számítástechnika & E(i) & $\circ 1$ & $\circ 2$ & $\circ 3$ & $\circ 4$ & $\circ 5$ & $\circ$ \\
\hline Magatartás & $E\left(D_{1}\right)$ & $\circ 1$ & $\circ 2$ & $\circ 3$ & $\circ 4$ & $\circ 5$ & 。 \\
\hline Szorgalom & E(d) & $\circ 1$ & $\circ 2$ & $\circ 3$ & $\circ 4$ & $\circ 5$ & 。 \\
\hline
\end{tabular}

Hányas voltál az elmúlt félév végén a következö tárgyakból?

\begin{tabular}{|c|c|c|c|c|c|c|c|}
\hline Tantárgy & Hang & Ėrdemjegy & Érdemjegy & Érdemjegy & Érdemjegy & Ėrdemjegy & \begin{tabular}{|c|}
$\begin{array}{c}\text { Nem tanultam } \\
\text { ilyen tárgyat }\end{array}$ \\
\end{tabular} \\
\hline Biológia & $\theta(1)$ & - 1 & . 2 & $\circ 3$ & $\circ 4$ & . 5 & 。 \\
\hline Fizika & E(D) & - 1 & - 2 & $\circ 3$ & - 4 & - 5 & 。 \\
\hline Kémia & E(N) & - 1 & - 2 & - 3 & - 4 & . 5 & 。 \\
\hline Földrajz & E(D) & - 1 & $\circ 2$ & $\circ 3$ & - 4 & $\circ 5$ & 。 \\
\hline Ének-zene & E(t) & 01 & $\circ 2$ & - 3 & - 4 & $\circ 5$ & 。 \\
\hline
\end{tabular}


Mennyire szereted a következö tárgyakat? Minden tantárgy esetén jelöld a téged leginkább jellemző választ!

\begin{tabular}{|c|c|c|c|c|c|c|c|}
\hline Tantárgy & Hang & $\begin{array}{c}\text { Nagyon } \\
\text { nem } \\
\text { szeretem }\end{array}$ & $\begin{array}{c}\text { Nem } \\
\text { szeretem }\end{array}$ & $\begin{array}{c}\text { Közömbös } \\
\text { nekem }\end{array}$ & Szeretem & $\begin{array}{l}\text { Nagyon } \\
\text { szeretem }\end{array}$ & $\begin{array}{c}\text { Nem } \\
\text { tanultan } \\
\text { ilyen } \\
\text { tárgyat }\end{array}$ \\
\hline Magyar nyelv és irodalom & (0) & $\circ$ & $\circ$ & $\circ$ & $\circ$ & $\circ$ & $\circ$ \\
\hline Idegen nyelv & (20) & $\circ$ & $\circ$ & 。 & $\circ$ & $\circ$ & ॰ \\
\hline Matematika & $(\theta 0)$ & $\circ$ & 。 & $\circ$ & $\circ$ & ○ & $\circ$ \\
\hline Történelem & (D) & $\circ$ & 。 & 。 & $\circ$ & ○ & $\circ$ \\
\hline Környezetismeret/természetismeret & (s) & $\circ$ & 。 & 。 & 。 & 。 & 。 \\
\hline
\end{tabular}

Mennyire szereted a következö tárgyakat? Minden tantárgy esetén jelöld a téged leginkább jellemző választ!

\begin{tabular}{|c|c|c|c|c|c|c|c|}
\hline Tantárgy & Hang & $\begin{array}{c}\text { Nagyon } \\
\text { nem } \\
\text { szeretem }\end{array}$ & $\begin{array}{c}\text { Nem } \\
\text { szeretem }\end{array}$ & $\begin{array}{l}\text { Közömbös } \\
\text { nekem }\end{array}$ & Szeretem & $\begin{array}{c}\text { Nagyon } \\
\text { szeretem }\end{array}$ & $\begin{array}{l}\text { Nem } \\
\text { tanultam } \\
\text { ilyen } \\
\text { tárgyat }\end{array}$ \\
\hline Rajz/vizuális kultúra & (c) (1)) & $\circ$ & $\circ$ & $\circ$ & $\circ$ & $\circ$ & $\circ$ \\
\hline Testnevelés & (E) & 。 & 。 & 。 & 。 & $\circ$ & $\circ$ \\
\hline Informatika/számítástechnika & (E) & $\circ$ & 。 & 。 & $\circ$ & 。 & $\circ$ \\
\hline Magatartás & (E) & $\circ$ & ○ & $\circ$ & $\circ$ & $\circ$ & $\circ$ \\
\hline Szorgalom & (i) & 。 & $\circ$ & $\circ$ & $\circ$ & $\circ$ & ○ \\
\hline
\end{tabular}


Mennyire szereted a következö tárgyakat? Minden tantárgy esetén jelöld a téged leginkább jellemző választ!

\begin{tabular}{|c|c|c|c|c|c|c|c|}
\hline Tantärgy & Hang & $\begin{array}{c}\text { Nagyon nem } \\
\text { szeretem }\end{array}$ & Nem szeretem & $\begin{array}{c}\text { Kòzömbös } \\
\text { nekem }\end{array}$ & Szeretem & $\begin{array}{c}\text { Nagyon } \\
\text { szeretem }\end{array}$ & $\begin{array}{c}\text { Nem tanultam } \\
\text { ilyen tárgyat }\end{array}$ \\
\hline Biológia & E(D) & 。 & 。 & 。 & 。 & 。 & 。 \\
\hline Fizika & E(d) & 。 & 。 & 。 & 。 & 。 & 。 \\
\hline Kémia & $\theta 0$ & 。 & 。 & 。 & 。 & 。 & 。 \\
\hline Földrajz & (E) & $\circ$ & 。 & $\circ$ & $\circ$ & 。 & $\circ$ \\
\hline Ének-zene & E(D) & 。 & 。 & 。 & 。 & 。 & 。 \\
\hline
\end{tabular}

\begin{tabular}{|c|c|c|c|}
\hline - angol & - német & - francia & - egyéb \\
\hline & & & \\
\hline & (5). (1) & (5) & (A) (1) \\
\hline
\end{tabular}


Hány idegen nyelvet tanulsz?

- Nem tanulok idegen nyelvet.

(5)
- 1

D(2))
- 2

(1))
- 3 vagy több

이)

Vissza

Tovább

Milyen idegen nyelvet tanulsz második nyelvként?

\begin{tabular}{|c|c|c|c|}
\hline - angol & - német & - francia & - egyéb \\
\hline (A) & (s) & (A) & E(A)) \\
\hline
\end{tabular}


Milyen tagozatra jársz?

írd a szövegdobozba!

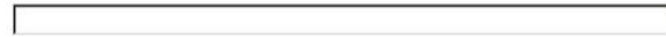

Milyen tantervü osztályba (csoportba) jársz? Jelöld a megfelelő választ!

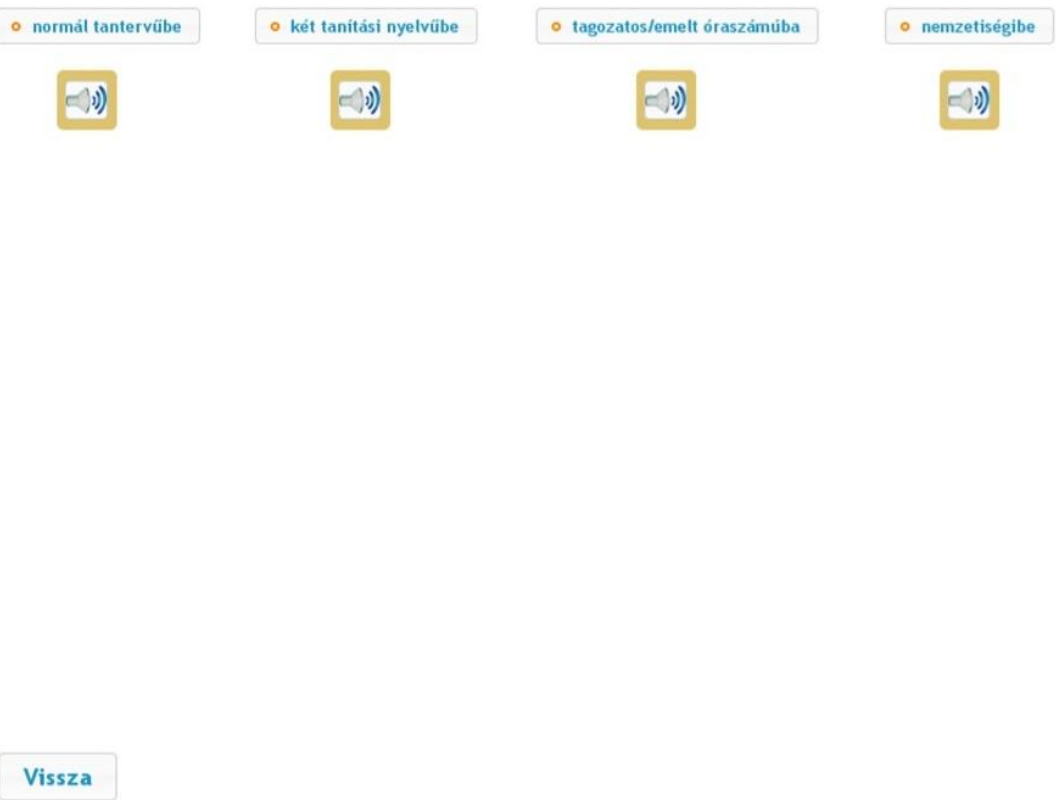

Tovább 
Milyen gyakran történnek meg a következö dolgok a Te családodban? minden állítás mellett jelöld a megfelelö választ!

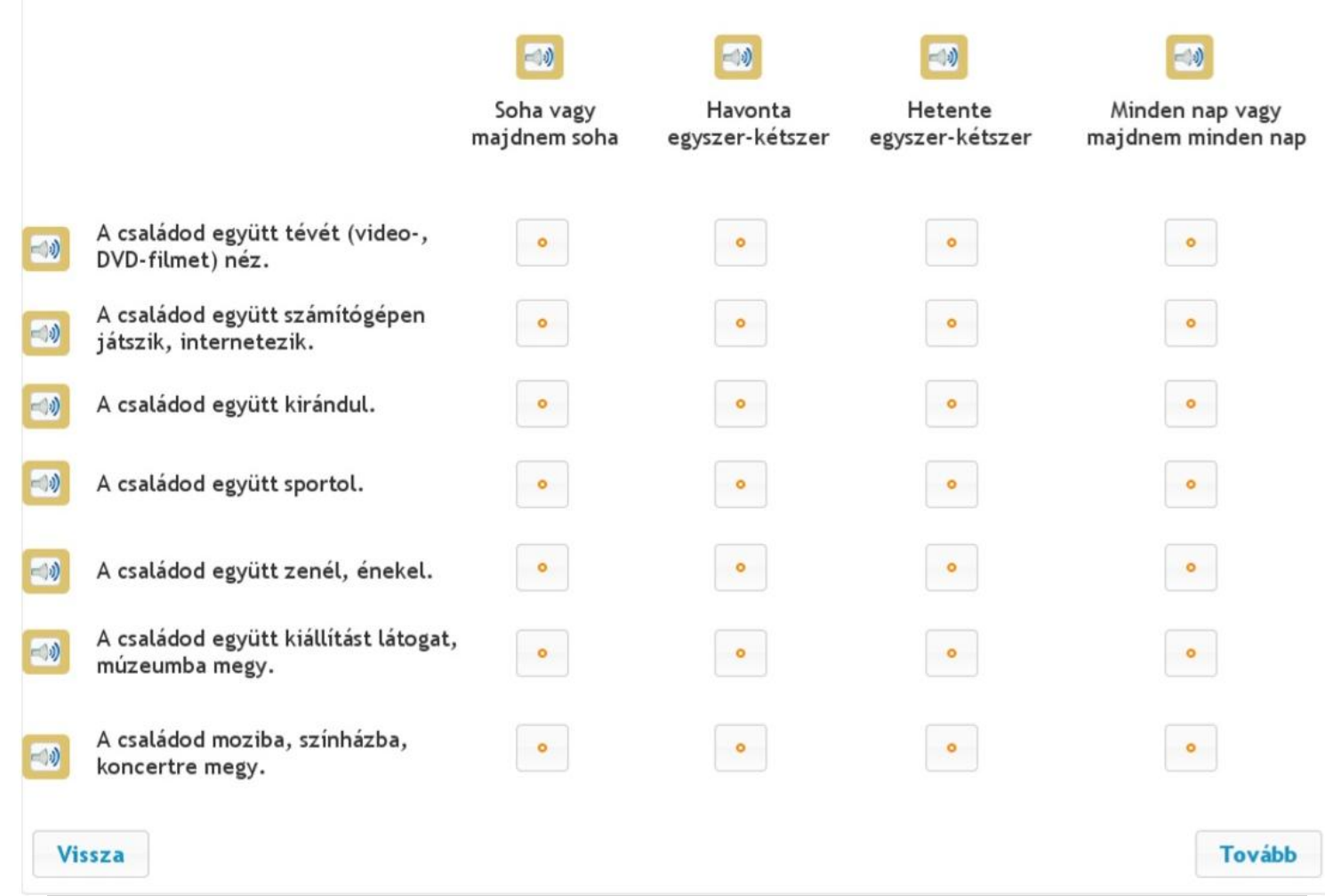

Mi édesapád/nevelőapád legmagasabb iskolai végzettsége? Jelöld a megfelelő választ!

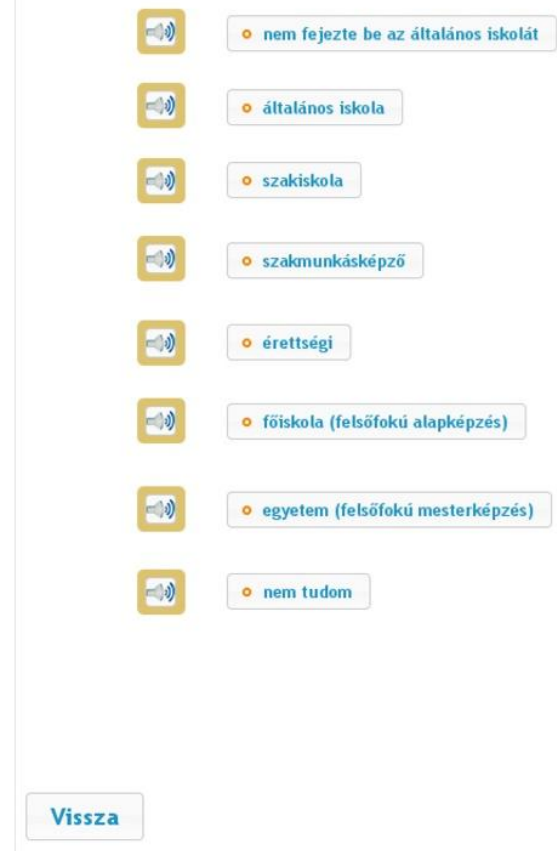




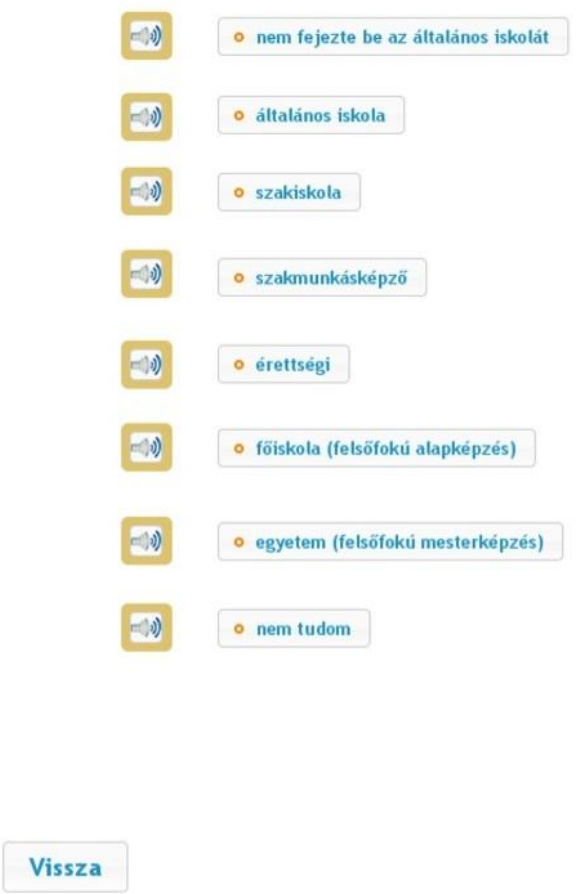

\begin{tabular}{|c|c|c|}
\hline - Saját családban élek & - Nevelöcsaládban élek & - Gyermekotthonban élek \\
\hline & & \\
\hline & & 皮 \\
\hline
\end{tabular}


$\circ$ igen Mennyivel? 19

(4)1)

Mi az a legmagasabb iskolai végzettség, amelyet szeretnél elérni? Jelölj meg egyet!

DAl4) abbahagyni az iskolát, amilyen hamar lehet

D(2)) $\circ$ elvégezni a nyolc általánost

B(14) $\quad$ szakmunkás végzettséget szerezni

(0) érettségizni

원) $\quad$ érettségi után szakképzettséget (technikusi vagy OKJ felsőfokú képzettséget) szerezni

돈) - diplomát szerezni felsöfokú alapképzésben (korábban föiskola)

C0.1) - diplomát szerezni felsốfokủ mesterkẻpzésen (korábban egyetem)

E (D)) doktori (PhD) fokozatot szerezni

Div) 0 még nem tudom 
Mennyire vagy elégedett a mostani iskolai teljesítményeiddel?

Jelöld a téged leginkább jellemző választ!

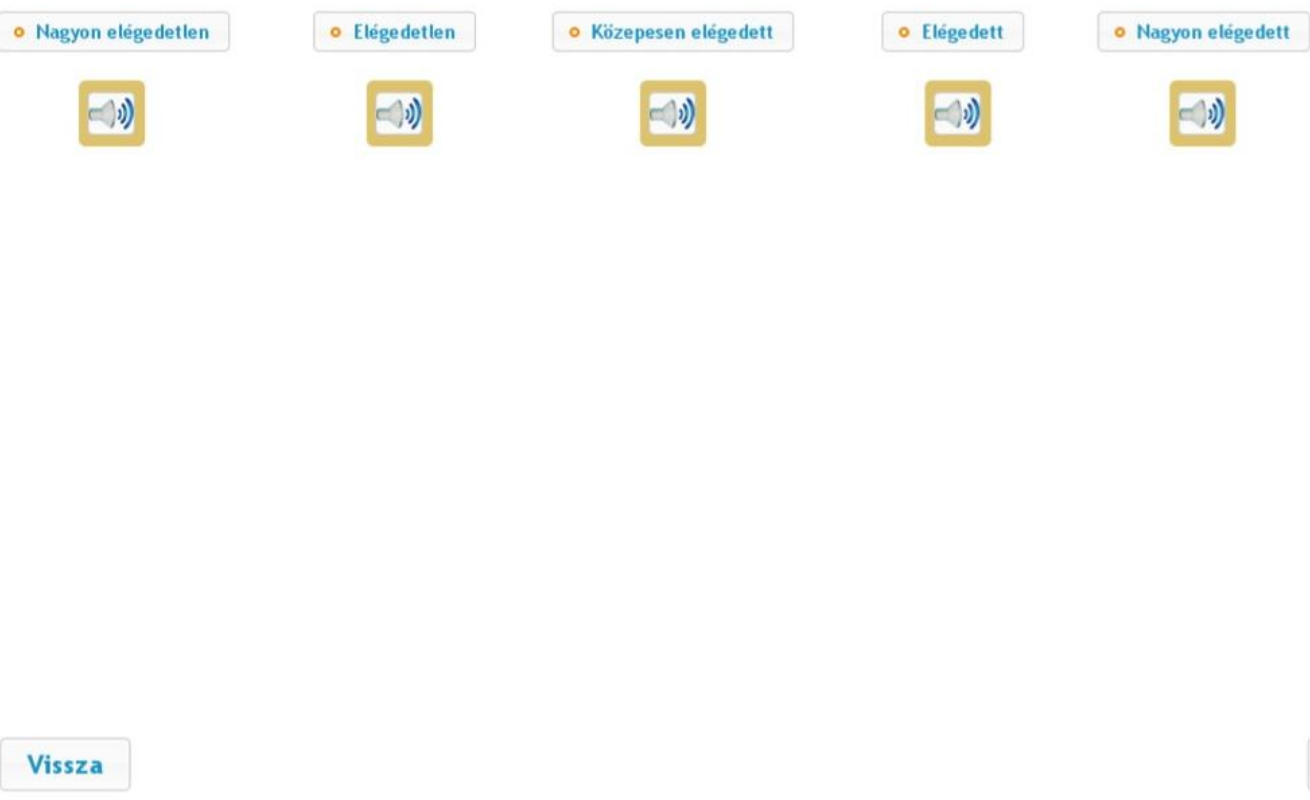

Tovább

Milyen a helyzeted az osztályodban? Mennyire jellemzök rád az alábbi állítások? Minden állítás mellett jelöld a rád leginkább jellemzö választ!

(a)

Sok barátom van az osztályban.

- Nem jellenzón

- Részben jellemzó

- Jellemzó

- Teljes mértékben jellemzố

Uivy érzem, az osztálytársaim szeretnek engem.

- Nem jellemzö

- Részben jellemzồ

- Jellemzö

Teljes mértékben jellemzố

Magányosnak érzem magam az osztályban.

- Nem jellemzö

- Részben jellemzồ

- Jellemzö

- Teljes mértékben jellemzö 


\section{5. sz. melléklet}

A 4. évfolyamos vizuális kommunikáció teszt feladatainak statisztikai mutatói

\begin{tabular}{|c|c|c|c|c|}
\hline Item & Átlag & Szórás & $\begin{array}{c}\text { Elkülönítés } \\
\text { mutató }\end{array}$ & $\begin{array}{c}\text { Cronbach- } \alpha \\
\text { változása az } \\
\text { item törlése } \\
\text { esetén }\end{array}$ \\
\hline piktogram_v1 & 0,66 & 0,473 & 0,292 & 0,872 \\
\hline piktogram_v2 & 0,96 & 0,187 & 0,462 & 0,871 \\
\hline piktogram_v4 & 0,94 & 0,238 & 0,381 & 0,871 \\
\hline piktogram_v5 & 0,96 & 0,193 & 0,322 & 0,872 \\
\hline piktogram_v6 & 0,83 & 0,372 & 0,287 & 0,872 \\
\hline piktogram_v7 & 0,98 & 0,153 & 0,396 & 0,872 \\
\hline piktogram_v8 & 0,95 & 0,224 & 0,268 & 0,872 \\
\hline 5sárkány_ok & 0,77 & 0,419 & 0,278 & 0,872 \\
\hline varázslóbenedek_v1 & 0,85 & 0,354 & 0,328 & 0,871 \\
\hline varázslóbenedek_v2 & 0,84 & 0,370 & 0,295 & 0,872 \\
\hline varázslóbenedek_v3 & 0,76 & 0,428 & 0,257 & 0,872 \\
\hline varázslóbenedek_v4 & 0,78 & 0,416 & 0,385 & 0,870 \\
\hline hidegszínekegérkés_ok & 0,91 & 0,281 & 0,279 & 0,872 \\
\hline színkeveréssárgaháromszirmúvirag & 0,63 & 0,482 & $-0,075$ & 0,878 \\
\hline színkeverés gyongyszinezes & 0,74 & 0,438 & 0,378 & 0,870 \\
\hline bukfenc & 0,56 & 0,498 & 0,282 & 0,872 \\
\hline haring & 0,62 & 0,487 & 0,240 & 0,873 \\
\hline piktogramoktélapó & 0,72 & 0,451 & 0,378 & 0,870 \\
\hline piktogramfurulya & 0,56 & 0,497 & 0,332 & 0,871 \\
\hline leplek_alatt 1 & 0,93 & 0,259 & 0,418 & 0,871 \\
\hline leplekalatt2 & 0,77 & 0,422 & 0,331 & 0,871 \\
\hline pontmozgása2 & 0,39 & 0,488 & 0,136 & 0,874 \\
\hline mozdulatok1_w1 & 0,89 & 0,314 & 0,441 & 0,870 \\
\hline mozdulatok1_w2 & 0,77 & 0,423 & 0,402 & 0,870 \\
\hline mozdulatok1_w3 & 0,80 & 0,404 & 0,322 & 0,871 \\
\hline mozdulatok1_w4 & 0,87 & 0,334 & 0,410 & 0,870 \\
\hline zene1_w1 - & 0,36 & 0,481 & 0,312 & 0,871 \\
\hline zene1_w2 & 0,45 & 0,499 & 0,256 & 0,872 \\
\hline zene1_w3 & 0,36 & 0,480 & 0,283 & 0,872 \\
\hline zene1_w4 & 0,59 & 0,492 & 0,380 & 0,870 \\
\hline zene2.56_w1 & 0,51 & 0,501 & 0,327 & 0,871 \\
\hline zene2.56_w2 & 0,35 & 0,477 & 0,233 & 0,873 \\
\hline zene2.56_w3 & 0,49 & 0,501 & 0,289 & 0,872 \\
\hline zeneII.56_w4 & 0,36 & 0,481 & 0,207 & 0,873 \\
\hline családfa & 0,32 & 0,468 & 0,082 & 0,875 \\
\hline pontmozgása3 & 0,63 & 0,484 & 0,290 & 0,872 \\
\hline pontmozgása3_ok2 & 0,60 & 0,491 & 0,382 & 0,870 \\
\hline pontmozgása3_ok3 & 0,53 & 0,500 & 0,376 & 0,870 \\
\hline pontmozgása3_ok4 & 0,49 & 0,501 & 0,389 & 0,870 \\
\hline pontmozgása3_ok5 & 0,55 & 0,498 & 0,341 & 0,871 \\
\hline szavakésábrák $\overline{4}$ _v1 & 0,80 & 0,398 & 0,463 & 0,869 \\
\hline szavakésábrák4_v2 & 0,56 & 0,497 & 0,403 & 0,870 \\
\hline
\end{tabular}




\begin{tabular}{lcccc} 
szavakésábrák4_v3 & 0,80 & 0,398 & 0,339 & 0,871 \\
szavakésábrák4_v4 & 0,92 & 0,274 & 0,470 & 0,870 \\
szavakésábrák4_x & 0,81 & 0,389 & 0,455 & 0,869 \\
szavakésábrák3_v1 & 0,92 & 0,274 & 0,462 & 0,870 \\
szavakésábrák3_v2 & 0,76 & 0,426 & 0,356 & 0,871 \\
szavakésábrák3_v5 & 0,85 & 0,359 & 0,357 & 0,871 \\
szavakésábrák3_y & 0,64 & 0,480 & 0,355 & 0,871 \\
Gainsborough & 0,90 & 0,305 & 0,335 & 0,871 \\
mozgalmas_m & 0,53 & 0,500 & 0,327 & 0,871 \\
mozgalmas_nm & 0,47 & 0,500 & 0,267 & 0,872 \\
térkép_v5 & 0,86 & 0,344 & 0,345 & 0,871 \\
térkép_v4 & 0,88 & 0,320 & 0,403 & 0,870 \\
térkép_v3 & 0,52 & 0,500 & 0,207 & 0,873 \\
térkép_v2 & 0,85 & 0,357 & 0,441 & 0,870 \\
térkép_v6 & 0,51 & 0,500 & 0,188 & 0,874 \\
\hline
\end{tabular}




\section{6. sz. melléklet}

A 5. évfolyamos vizuális kommunikáció teszt feladatainak statisztikai mutatói

\begin{tabular}{|c|c|c|c|c|}
\hline Item & Átlag & Szórás & $\begin{array}{c}\text { Elkülönítés } \\
\text { mutató }\end{array}$ & $\begin{array}{c}\text { Cronbach- } \alpha \\
\text { változása az item } \\
\text { törlése esetén }\end{array}$ \\
\hline piktogram_v1 & 0,69 & 0,464 & 0,333 & 0,886 \\
\hline piktogram_v2 & 0,97 & 0,157 & 0,448 & 0,886 \\
\hline piktogram_v4 & 0,95 & 0,213 & 0,402 & 0,886 \\
\hline piktogram_v5 & 0,98 & 0,136 & 0,434 & 0,886 \\
\hline piktogram_v6 & 0,85 & 0,356 & 0,299 & 0,886 \\
\hline piktogram_v7 & 0,98 & 0,136 & 0,434 & 0,886 \\
\hline piktogram_v8 & 0,97 & 0,166 & 0,388 & 0,886 \\
\hline piktogramfurulya & 0,47 & 0,500 & 0,215 & 0,887 \\
\hline pontmozgása2 & 0,45 & 0,499 & 0,241 & 0,887 \\
\hline zene1_w1 & 0,50 & 0,501 & 0,396 & 0,885 \\
\hline zene1_w2 & 0,46 & 0,499 & 0,273 & 0,887 \\
\hline zene1_w3 & 0,35 & 0,477 & 0,349 & 0,885 \\
\hline zene1_w4 & 0,50 & 0,501 & 0,289 & 0,886 \\
\hline zene2.56_w1 & 0,44 & 0,497 & 0,232 & 0,887 \\
\hline zene2.56_w2 & 0,35 & 0,478 & 0,273 & 0,886 \\
\hline zene2.56_w3 & 0,41 & 0,492 & 0,288 & 0,886 \\
\hline zene2-56_w4 & 0,39 & 0,489 & 0,182 & 0,888 \\
\hline pontmozgása3_ok1 & 0,65 & 0,478 & 0,461 & 0,884 \\
\hline pontmozgása3_ok2 & 0,67 & 0,470 & 0,396 & 0,885 \\
\hline pontmozgása3_ok3 & 0,55 & 0,498 & 0,390 & 0,885 \\
\hline pontmozgása3_ok4 & 0,55 & 0,498 & 0,459 & 0,884 \\
\hline pontmozgása3_ok5 & 0,60 & 0,491 & 0,375 & 0,885 \\
\hline szavakésábrák $\overline{3} \_v 1$ & 0,68 & 0,468 & 0,250 & 0,887 \\
\hline szavakésábrák3_v2 & 0,72 & 0,450 & 0,205 & 0,887 \\
\hline szavakésábrák3_v5 & 0,86 & 0,350 & 0,306 & 0,886 \\
\hline szavakésábrák3_v6 & 0,93 & 0,260 & 0,326 & 0,886 \\
\hline térkép56_v5 & 0,85 & 0,356 & 0,316 & 0,886 \\
\hline térkép56_v4 & 0,86 & 0,346 & 0,393 & 0,885 \\
\hline térkép56_v3 & 0,58 & 0,495 & 0,203 & 0,887 \\
\hline térkép56_v2 & 0,89 & 0,318 & 0,439 & 0,885 \\
\hline térkép56_v6 & 0,57 & 0,496 & 0,122 & 0,889 \\
\hline höfokkontraszt_ok1_meleg & 0,88 & 0,322 & 0,290 & 0,886 \\
\hline höfokkontraszt_ok2_hideg & 0,82 & 0,385 & 0,358 & 0,885 \\
\hline színkeveres_gyongyszinezes & 0,56 & 0,497 & 0,390 & 0,885 \\
\hline színfelismerés56_1 & 0,69 & 0,462 & 0,294 & 0,886 \\
\hline színfelismerés56_2 & 0,50 & 0,501 & 0,303 & 0,886 \\
\hline színfelismerés56_3 & 0,92 & 0,270 & 0,241 & 0,887 \\
\hline színfelismerés56_4 & 0,71 & 0,453 & 0,251 & 0,887 \\
\hline batman__ - & 0,03 & 0,183 & 0,036 & 0,888 \\
\hline mondrian & 0,69 & 0,462 & 0,308 & 0,886 \\
\hline leplekalatt2 & 0,65 & 0,478 & 0,208 & 0,887 \\
\hline képkivágás & 0,79 & 0,404 & 0,338 & 0,886 \\
\hline egyiptomiistenek_v1 & 0,87 & 0,336 & 0,456 & 0,885 \\
\hline
\end{tabular}




\begin{tabular}{lllll} 
egyiptomiistenek_v2 & 0,89 & 0,310 & 0,455 & 0,885 \\
egyiptomiistenek_v3 & 0,90 & 0,306 & 0,461 & 0,885 \\
egyiptomiistenek_v4 & 0,70 & 0,460 & 0,373 & 0,885 \\
piktogram_ketchup & 0,43 & 0,496 & 0,356 & 0,885 \\
mozgalmas_ok1_mozgalmas & 0,47 & 0,500 & 0,335 & 0,886 \\
mozgalmas_ok2_nemmozgalmas & 0,43 & 0,496 & 0,310 & 0,886 \\
okeffee_ok1 & 0,86 & 0,350 & 0,451 & 0,885 \\
okeffee_ok2 & 0,76 & 0,426 & 0,319 & 0,886 \\
okeffee_ok & 0,72 & 0,450 & 0,285 & 0,886 \\
szavakesabrak2_v2 & 0,74 & 0,437 & 0,441 & 0,884 \\
szavakesabrak2_v3 & 0,68 & 0,468 & 0,277 & 0,886 \\
szavakesabrak2_v4 & 0,72 & 0,449 & 0,343 & 0,886 \\
szavakesabrak2_v5 & 0,82 & 0,382 & 0,395 & 0,885 \\
szavakesabrak2_v6 & 0,49 & 0,501 & 0,167 & 0,888 \\
gerenda_ok & 0,66 & 0,476 & 0,302 & 0,886 \\
palacsintasorrend_ok & 0,77 & 0,424 & 0,284 & 0,886 \\
picasso_ok1 & 0,81 & 0,395 & 0,443 & 0,884 \\
picasso_ok2 & 0,82 & 0,387 & 0,478 & 0,884 \\
picasso_ok3 & 0,91 & 0,289 & 0,411 & 0,885 \\
picasso_ok4 & 0,79 & 0,411 & 0,246 & 0,887 \\
picasso_ok5 & 0,72 & 0,449 & 0,338 & 0,886 \\
\hline
\end{tabular}




\section{7. sz. melléklet}

A 6. évfolyamos vizuális kommunikáció teszt feladatainak statisztikai mutatói

\begin{tabular}{|c|c|c|c|c|}
\hline Item & Átlag & Szórás & $\begin{array}{l}\text { Elkülönítés } \\
\text { mutató }\end{array}$ & $\begin{array}{l}\text { Cronbach- } \alpha \\
\text { változása az } \\
\text { item törlése } \\
\text { esetén }\end{array}$ \\
\hline piktogramfurulya & 0,51 & 0,500 & 0,306 & 0,894 \\
\hline pontmozgása2 & 0,39 & 0,488 & 0,147 & 0,895 \\
\hline zene1_w1 & 0,51 & 0,500 & 0,353 & 0,893 \\
\hline zene1_w2 & 0,52 & 0,500 & 0,252 & 0,894 \\
\hline zene1_w3 & 0,39 & 0,487 & 0,247 & 0,894 \\
\hline zene1_w4 & 0,56 & 0,497 & 0,336 & 0,893 \\
\hline zene2.56_w1 & 0,48 & 0,500 & 0,251 & 0,894 \\
\hline zene2.56_w2 & 0,45 & 0,498 & 0,166 & 0,895 \\
\hline zene2.56_w3 & 0,52 & 0,500 & 0,200 & 0,895 \\
\hline zene2.56_w4 & 0,37 & 0,482 & 0,154 & 0,895 \\
\hline pontmozgása3_ok1 & 0,62 & 0,486 & 0,338 & 0,893 \\
\hline pontmozgása3_ok2 & 0,60 & 0,491 & 0,413 & 0,893 \\
\hline pontmozgása3_ok3 & 0,52 & 0,500 & 0,474 & 0,892 \\
\hline pontmozgása3_ok4 & 0,51 & 0,500 & 0,372 & 0,893 \\
\hline pontmozgása3_ok5 & 0,58 & 0,494 & 0,307 & 0,894 \\
\hline szavakésábrák3_v1 & 0,74 & 0,441 & 0,311 & 0,894 \\
\hline szavakésábrák3_v2 & 0,75 & 0,433 & 0,351 & 0,893 \\
\hline szavakésábrák3_v5 & 0,85 & 0,355 & 0,377 & 0,893 \\
\hline 6szavakésábrák $\overline{3} \_y$ & 0,94 & 0,242 & 0,393 & 0,894 \\
\hline térkép56_v5 & 0,82 & 0,387 & 0,490 & 0,892 \\
\hline térkép56_v4 & 0,85 & 0,353 & 0,507 & 0,892 \\
\hline térkép56_v3 & 0,56 & 0,497 & 0,185 & 0,895 \\
\hline térkép56_v2 & 0,85 & 0,353 & 0,475 & 0,892 \\
\hline térkép56_v6 & 0,60 & 0,491 & 0,251 & 0,894 \\
\hline színfelismerés56_1 & 0,79 & 0,406 & 0,271 & 0,894 \\
\hline színfelismerés56_2 & 0,56 & 0,496 & 0,284 & 0,894 \\
\hline színfelismerés $56 \_3$ & 0,94 & 0,238 & 0,219 & 0,894 \\
\hline színfelismerés56_4 & 0,73 & 0,442 & 0,207 & 0,895 \\
\hline batman & 0,04 & 0,185 & $-0,054$ & 0,896 \\
\hline mondrian & 0,80 & 0,401 & 0,223 & 0,894 \\
\hline leplekalatt2_ & 0,70 & 0,458 & 0,110 & 0,896 \\
\hline okeffee_ok1 & 0,88 & 0,326 & 0,399 & 0,893 \\
\hline okeffee_ok2 & 0,75 & 0,434 & 0,276 & 0,894 \\
\hline okeffee_ok & 0,74 & 0,436 & 0,193 & 0,895 \\
\hline szavakesabrak2_v2 & 0,68 & 0,468 & 0,406 & 0,893 \\
\hline szavakesabrak2_v3 & 0,65 & 0,479 & 0,212 & 0,895 \\
\hline szavakesabrak2_v4 & 0,70 & 0,458 & 0,387 & 0,893 \\
\hline szavakesabrak2_v5 & 0,78 & 0,417 & 0,347 & 0,893 \\
\hline szavakesabrak2_v6 & 0,45 & 0,498 & 0,251 & 0,894 \\
\hline picasso_ok1 & 0,85 & 0,355 & 0,400 & 0,893 \\
\hline picasso_ok2 & 0,85 & 0,359 & 0,412 & 0,893 \\
\hline picasso_ok3 & 0,91 & 0,288 & 0,310 & 0,894 \\
\hline
\end{tabular}




\begin{tabular}{lllll} 
picasso_ok4 & 0,80 & 0,400 & 0,311 & 0,894 \\
picasso_ok5 & 0,75 & 0,432 & 0,339 & 0,893 \\
haring1_v1 & 0,77 & 0,424 & 0,356 & 0,893 \\
haring1_v2 & 0,70 & 0,457 & 0,408 & 0,893 \\
haring1_v3 & 0,64 & 0,480 & 0,349 & 0,893 \\
warhol2_ok & 0,82 & 0,383 & 0,205 & 0,895 \\
lovak_ok & 0,61 & 0,488 & 0,315 & 0,894 \\
tavasz_ok & 0,49 & 0,500 & 0,172 & 0,895 \\
mozdulatok3_v1 & 0,78 & 0,415 & 0,210 & 0,895 \\
mozdulatok3_v2 & 0,70 & 0,458 & 0,152 & 0,895 \\
mozdulatok3_v3 & 0,90 & 0,300 & 0,246 & 0,894 \\
mozdulatok3_v4 & 0,66 & 0,473 & 0,152 & 0,895 \\
tornagyakorlatok2_v1 & 0,88 & 0,328 & 0,230 & 0,894 \\
tornagyakorlatok2_v2 & 0,73 & 0,442 & 0,329 & 0,893 \\
tornagyakorlatok2_v3 & 0,64 & 0,480 & 0,351 & 0,893 \\
tornagyakorlatok2_v4 & 0,62 & 0,486 & 0,313 & 0,894 \\
görögmitológiailények_v1 & 0,81 & 0,392 & 0,459 & 0,892 \\
görögmitológiailények_v2 & 0,89 & 0,318 & 0,430 & 0,893 \\
görögmitológiailények_v3 & 0,86 & 0,351 & 0,499 & 0,892 \\
görögmitológiailények_v4 & 0,76 & 0,425 & 0,353 & 0,893 \\
görögmitológiailények_v5 & 0,82 & 0,387 & 0,466 & 0,892 \\
topográfia_v1 & 0,79 & 0,404 & 0,476 & 0,892 \\
topográfia_v2 & 0,74 & 0,441 & 0,467 & 0,892 \\
topográfia_v3 & 0,73 & 0,444 & 0,411 & 0,893 \\
topográfia_v4 & 0,76 & 0,429 & 0,442 & 0,892 \\
topográfia_v5 & 0,62 & 0,486 & 0,339 & 0,893 \\
metro_v1 & 0,82 & 0,385 & 0,344 & 0,893 \\
metro_v2 & 0,59 & 0,492 & 0,222 & 0,895 \\
metro_v3 & 0,75 & 0,434 & 0,445 & 0,892 \\
metro_v4 & 0,62 & 0,485 & 0,302 & 0,894 \\
\hline
\end{tabular}




\section{A jelölt disszertációhoz kapcsolódó publikációi}

Kárpáti Andrea, Simon Tünde (2013): Creation and interpretation of visual metaphors and The Symbolisation in child art: assessment of symbolisation skills. Proceedings of VLL 4 Visual Learning Emotion-Expression-Explanation, Budapest, Hungary 15-16. Nov. 2013.

Kárpáti Andrea, Simon Tünde (2013): Vizuális kommunikáció: képességek, fejlödés, mérési lehetöségek. Előadás: XIII. Országos Neveléstudományi Konferencia, Eger, 2013.

Simon Tünde (2013): A zene és a képzömüvészet közös nyelve. Parlando 2013/2 http://www.parlando.hu/2013/2013-2/SimonTunde-Zene_es_kepzomuveszet.pdf

Simon Tünde (2013): Online assessement of visual communication skills. Proceedings of the International Society for Education Through Art (InSEA) World Congress, Canterbury, UK, 24-26 June 2013.

Kárpáti Andrea, Simon Tünde (2014): A vizuális kommunikáció összetevői és online mérése 10-12 éves korban. In.: Új kutatások a neveléstudományokban 2013. Változó életformák, régi és új tanulási környezetek. MTA Pedagógiai Tudományos Társaság

Kárpáti Andrea, Simon Tünde (2014): Symbolization in Child Art. Creation and Interpretation of Visual Metaphors In.: The Power of the Image edited by András Benedek and Kristóf Nyíri

Kárpáti Andrea, Simon Tünde, Steklács János (2014): Vizuális kommunikáció képességcsoport vizsgálata szemmozgás-elemzés módszerével. Előadás: XII. Pedagógiai Értékelési Konferencia - PÉK, Szeged, 2014.

Kárpáti, A., Simon, T., Babály, B., és Budai, L. (2015): Az eDIA online tesztrendszer pilot kisérletei a Térszemlélet és Vizuális kommunikáció területén. In: Zsolnai Anikó és Csapó Benő (szerk.): Online diagnosztikus mérések az iskola kezdő szakaszában.

Simon Tünde (2014): Az absztrakció, mint a vizuális kommunikáció részképessége, online mérési és fejlesztési lehetőségei. Agria-média Konferencia, Eger,

Simon Tünde (2014): Online assessement of visual communication skills. Proceedings of the International Society for Education Through Art (InSEA) World Congress, Canterbury, UK, 24-26 June 2013. Zárókötet.

http://insea.org/docs/2014.17/InSEACongress2013PROCEEDINGS.pdf

Simon Tünde (2015): A vizuális kommunikáció képességcsoportjának értelmezése és fejlödése 10-12 éves korban. Iskolakultúra 25. évf. 15/02. sz. 32-47.

Simon Tünde (2015): Az észt információs társadalom és oktatási rendszere. Országtanulmány. Infonia 2015/4

Simon Tünde (2015): Online assessment of visual communication skills of students aged 1012. InSEA European Regional Congress, Risk and Opportunities for Visual Art Education in Europe. Culturgest, Lsbon, 7-9 July 2015. https://arteducation15.files.wordpress.com/2015/04/tucc88nde-irecc81n-simon.pdf Elfogadott absztrakt

Simon Tünde (2015): The place and role of visual education in institutional cooperation. 6th International Conference on Literacy 22-24 May Rethymno Campus, Crete.

Simon Tünde (2015): Visual Communication in everyday school practice. KF-TFK Szemmozgás Olvasás Módszertani Kutatómühely, Tobii Technology. Conference on Eye Movements. Kecskemét,.8. June 2015

Simon Tünde (2015): Vizuális kommunikáció online mérése a 10-12 éves korosztályban. Országos Neveléstudományi Konferencia. Elfogadott absztrakt.

Simon Tünde (2015): Vizuális kommunikációs tananyagok értelmezése és értékelési lehetőségei. „Mérés és értékelés a vizuális kultúra tanításában” konferencia, Eszterházy Károly Főiskola Comenius Kara, Sárospatak, 2015. november 16. 
Simon Tünde, Bubik Vera (2016): Vizuális kommunikáció: a 21. század domináns közlésmódja a kortárs müvészetben és tudományban, megjelenése a vizuális nevelésben. Neveléstudomány. 2016/2 29-43.o.

A dolgozatban a 1-6. fejezetek alapját korábban már megjelent tanulmányaink adták, de a tanulmányok átdolgozáson estek át. Kutatásainkat az SZTE Oktatáselméleti Kutatócsoport, az MTA-SZTE Képességfejlődés Kutatócsoport, valamint az SZTE Neveléstudományi Doktori Iskola infrastruktúrájának felhasználásával valósítottuk meg, a kutatás a Diagnosztikus mérések fejlesztése (2009-2015) TÁMOP-3.1.9-08/1-2009-0001 (1. fázis) és a TÁMOP-3.1.9-11/1-2012-0001 (2. fázis) keretében zajlott. 